\title{
Modeled and Measured Glacier Change and Related Glaciological, Hydrological, and Meteorological Conditions at South Cascade Glacier, Washington, Balance and Water Years 2006 and 2007
}

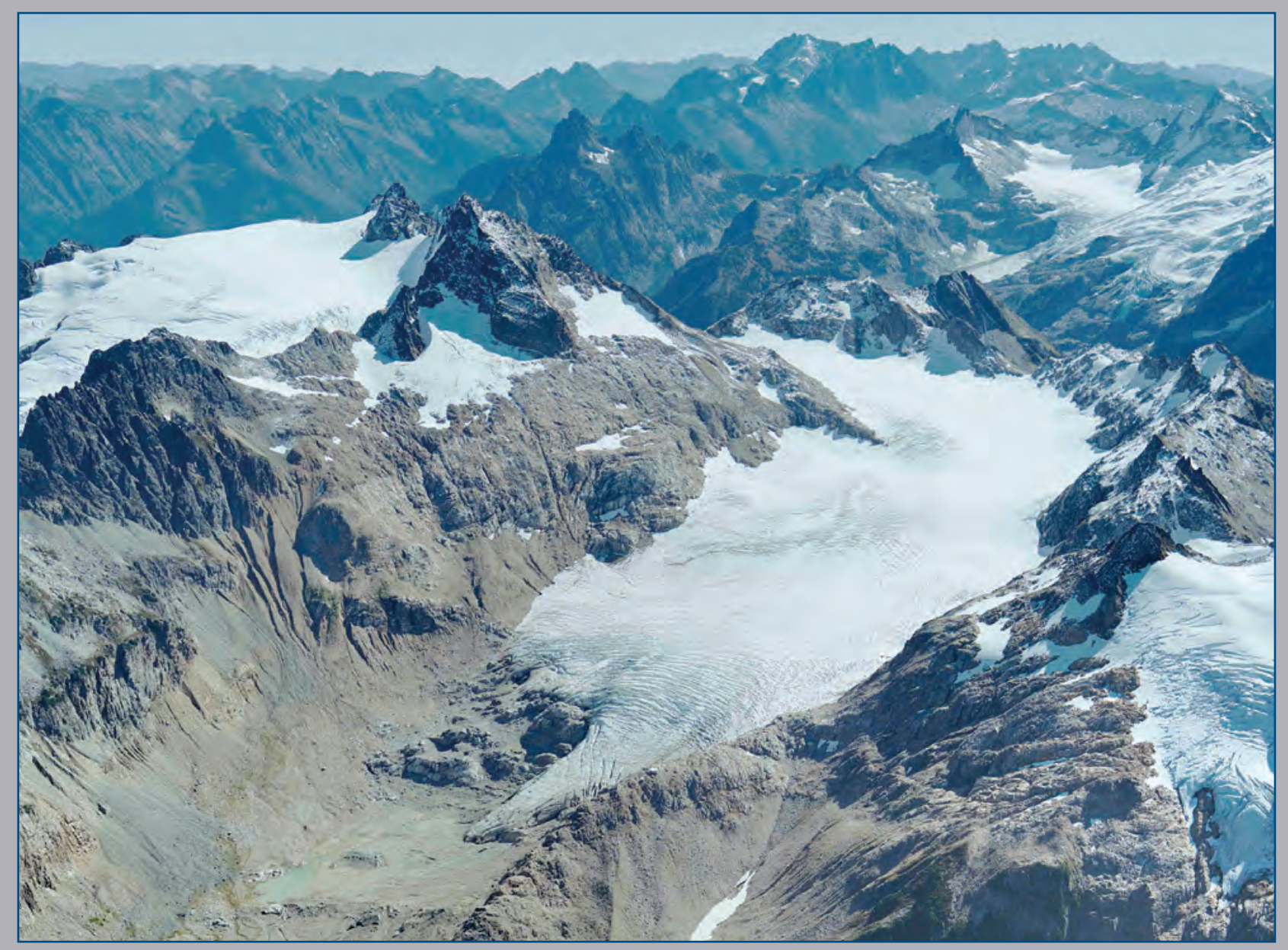

Scientific Investigations Report 2010-5143 
Cover: Photograph of South Cascade Glacier, Washington, from the northnorthwest, September 24, 2006. (Photograph taken by Vern Potts, Washington State Department of Transportation, for the U.S. Geological Survey.) 


\section{Modeled and Measured Glacier Change and Related Glaciological, Hydrological, and Meteorological Conditions at South Cascade Glacier, Washington, Balance and Water Years 2006 and 2007}

By William R. Bidlake, Edward G. Josberger, and Mark E. Savoca

Scientific Investigations Report 2010-5143 


\title{
U.S. Department of the Interior \\ KEN SALAZAR, Secretary
}

\section{U.S. Geological Survey \\ Marcia K. McNutt, Director}

\section{U.S. Geological Survey, Reston, Virginia: 2010}

\begin{abstract}
For more information on the USGS - the Federal source for science about the Earth, its natural and living resources, natural hazards, and the environment, visit http://www.usgs.gov or call 1-888-ASK-USGS

For an overview of USGS information products, including maps, imagery, and publications, visit http://www.usgs.gov/pubprod

To order this and other USGS information products, visit http://store.usgs.gov
\end{abstract}

Any use of trade, product, or firm names is for descriptive purposes only and does not imply endorsement by the U.S. Government.

Although this report is in the public domain, permission must be secured from the individual copyright owners to reproduce any copyrighted materials contained within this report.

Suggested citation:

Bidlake, W.R., Josberger, E.G., and Savoca, M.E., 2010, Modeled and measured glacier change and related glaciological, hydrological, and meteorological conditions at South Cascade Glacier, Washington, balance and water years 2006 and 2007: U.S. Geological Survey Scientific Investigations Report 2010-5143, 82 p. 


\section{Contents}

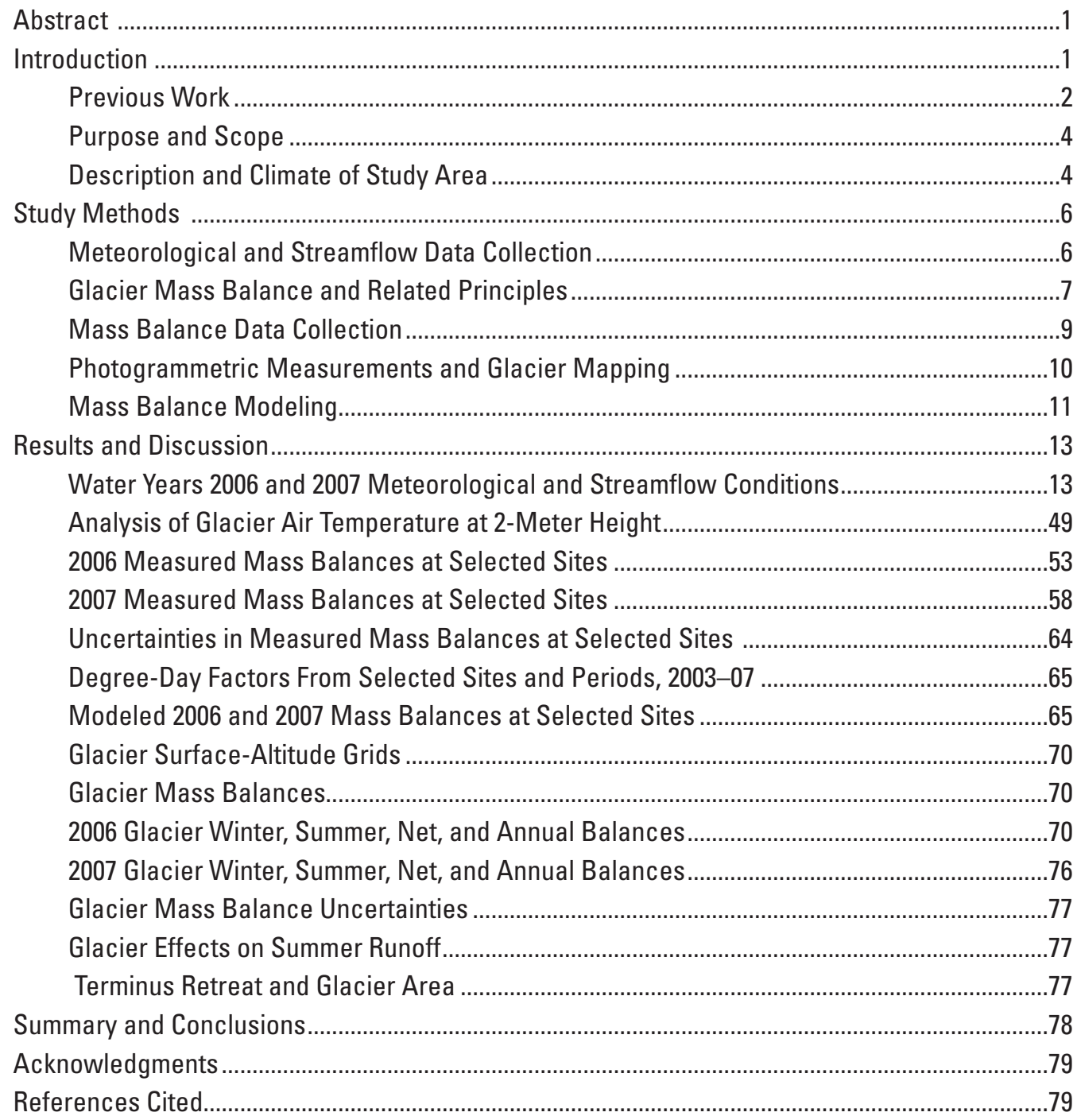




\section{Data CD}

[In pocket]

Surface-altitude grid data for South Cascade Glacier, Washington, 2006 and 2007.

\section{Figures}

Figure 1. Map showing location of the study area, South Cascade Lake basin, Washington 3

Figure 2. Map showing South Cascade Glacier and vicinity, Washington $\ldots \ldots \ldots \ldots \ldots \ldots \ldots$

Figure 3. Graphs showing hourly average air temperature at selected sites in and near South Cascade Lake basin, Washington, water year $2006 \quad \ldots \ldots \ldots \ldots \ldots \ldots \ldots 20$

Figure 4. Graphs showing hourly average air temperature at selected sites in and near South Cascade Lake basin, Washington, water year $2007 \quad \ldots \ldots \ldots \ldots \ldots \ldots \ldots \ldots 21$

Figure 5. Graphs showing air temperature at a height of 2 meters recorded at 10-minute intervals at three mass balance sites on South Cascade Glacier, Washington, April-September 2006

Figure 6. Graphs showing air temperature at a height of 2 meters recorded at 10-minute intervals at three mass balance sites on South Cascade Glacier, Washington, May-September 2007.

Figure 7. Graphs showing hourly average wind speed and incoming solar radiation at the Hut, 1,842 meters altitude, near South Cascade Lake basin, Washington, water year 2006

Figure 8. Graphs showing hourly average wind speed and incoming solar radiation at the Hut, 1,842 meters altitude, near South Cascade Lake basin, Washington, water year 2007

Figure 9. Graphs showing hourly precipitation (gage catch) at the Salix Creek gaging station, stage of Middle Tarn and Salix Creek, and daily average runoff from Middle Tarn and Salix Creek basins, Washington, water year 2006

Figure 10. Graphs showing ratio of monthly Middle Tarn and Salix Creek basin runoff to monthly precipitation (gage catch) at the Salix Creek gaging station, Washington, June-September, water years 2006 and 2007

Figure 11. Graphs showing hourly precipitation (gage catch) at the Salix Creek gaging station, stage of Middle Tarn and Salix Creek, and daily average runoff from Middle Tarn and Salix Creek basins, Washington, water year 2007

Figure 12. Graph showing air-temperature difference between the temperature reference at the Hut and at 2-meters-height at selected mass balance sites on South Cascade Glacier, Washington, as it varied with Hut-to-site altitude difference, during parts of April-0ctober, water years 2003-07

Figure 13. Graph showing measured and modeled daily average air temperature at 2-meters-height at selected mass balance sites on South Cascade Glacier, Washington, as they varied with free-atmosphere temperature predicted from temperature at a reference site, the altitude difference between the reference and mass balance sites, and using a constant temperature lapse rate, during parts of April-0ctober, water years 2003-2007 


\section{Figures-Continued}

Figure 14. Map showing partial and complete outlines of South Cascade Glacier, Washington, 2005 and 2006, and locations of 2006 measurement sites for snow depth and

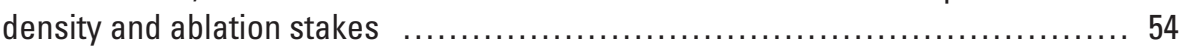

Figure 15. Image of South Cascade Glacier, Washington, September 28, 2006 ............. 56

Figure 16. Map showing partial and complete outlines of South Cascade Glacier, Washington, 2006 and 2007, and locations of 2007 measurement sites for snow

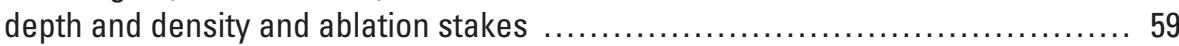

Figure 17. Image of South Cascade Glacier, Washington, constructed from vertical aerial

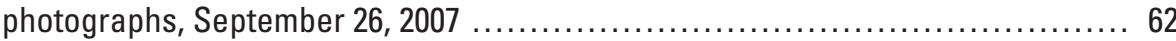

Figure 18. Graph showing cumulative snow and new firn, and ice mass balances at six mass balance sites on South Cascade Glacier, Washington, from the beginning of balance year 2006 to December 31, 2007

Figure 19. Graph showing mass balances at six mass balance sites on South Cascade Glacier, Washington, and glacier mass balance, from the beginning of balance year 2006 to December 31, 2007.

Figure 20. Map showing 2006 surface-altitude grid for South Cascade Glacier, measured from vertical aerial photographs taken September 28, 2006 ....

Figure 21. 2007 surface-altitude grid for South Cascade Glacier, measured from vertical aerial photographs taken September 28, 2006, and September 26, 2007

Figure 22. Graph showing winter, summer, and net balances of South Cascade Glacier, Washington, 1953 and 1955-2007

\section{Tables}

Table 1. Daily maximum, minimum, and average of hourly average air temperature at the Hut, 1,842 meters altitude, near South Cascade Lake basin, Washington, water year 2006

Table 2. Daily maximum, minimum, and average of hourly average air temperature at the Middle Tarn gaging station, 1,631 meters altitude, Middle Tarn basin, Washington, water year 2006

Table 3. Daily maximum, minimum, and average of hourly average air temperature at the Salix Creek gaging station, 1,587 meters altitude, Salix Creek basin, Washington, water year 2006

Table 4. Daily maximum, minimum, and average of hourly average air temperature at the Hut, 1,842 meters altitude, near South Cascade Lake basin, Washington, water year 2007

Table 5. Daily maximum, minimum, and average of hourly average air temperature at the Middle Tarn gaging station, 1,631 meters altitude, Middle Tarn basin, Washington, water year 2007

Table 6. Daily maximum, minimum, and average of hourly average air temperature at the Salix Creek gaging station, 1,587 meters altitude, Salix Creek basin, Washington, water year 2007

Table 7. Daily maximum, minimum, and average 2-meter-height air temperature at mass balance site $\mathrm{S} 1950$ on South Cascade Glacier, Washington, 1,945 meters altitude, April-September 2006 


\section{Tables-Continued}

Table 8. Daily maximum, minimum, and average 2-meter-height air temperature at mass balance site S1840P-1 on South Cascade Glacier, Washington, 1,837 meters altitude, April-September 2006

Table 9. Daily maximum, minimum, and average 2-meter-height air temperature at mass balance site S1670 on South Cascade Glacier, Washington, 1,674 meters altitude, April-September 2006

Table 10. Daily maximum, minimum, and average 2-meter-height air temperature at mass balance site S2070 on South Cascade Glacier, Washington, 2,066 meters altitude, May-September 2007

Table 11. Daily maximum, minimum, and average 2-meter-height air temperature at mass balance site S1840P-1 on South Cascade Glacier, Washington, 1,836 meters estimated altitude, May-September 2007

Table 12. Daily maximum, minimum, and average 2-meter-height air temperature at mass balance site S1670 on South Cascade Glacier, Washington, 1,668 meters altitude, May-September 2007

Table 13. Daily average wind speed at the Hut, 1,842 meters altitude, near South Cascade Lake basin, Washington, water year 2006

Table 14. Daily average wind speed at the Hut, 1,842 meters altitude, near South Cascade Lake basin, Washington, water year 2007

Table 15. Daily average incoming solar radiation at the Hut, 1,842 meters altitude, near South Cascade Lake basin, Washington, water year 2006

Table 16. Daily average incoming solar radiation at the Hut, 1,842 meters altitude, near South Cascade Lake basin, Washington, water year 2007

Table 17. Daily total precipitation (gage catch) at the Salix Creek gaging station, Salix Creek basin, Washington, 1,587 meters altitude, water year 2006

Table 18. Daily average runoff from Middle Tarn basin, Washington, October and November, and June-September, water year 2006

Table 19. Miscellaneous stream discharge measurements made at Middle Tarn outlet, South Fork of Cascade River, and Salix Creek near Salix Creek gaging station, Washington, water years 2006 and 2007

Table 20. Daily average runoff from Salix Creek basin at the Salix Creek gaging station, Washington, water year 2006

Table 21. Daily total precipitation (gage catch) at the Salix Creek gaging station, Salix Creek basin, Washington, 1,587 meters altitude, water year 2007 ....

Table 22. Daily average runoff from Middle Tarn basin, Washington, October, August, and September, water year 2007

Table 23. Daily average runoff from Salix Creek basin at the Salix Creek gaging station, Washington, water year 2007

Table 24. Coefficients for equations for estimating effect of South Cascade Glacier, Washington, on air temperature at a height of 2 meters above the glacier surface at five mass balance sites 


\section{Tables-Continued}

Table 25. Snow depth and snow mass balance at selected locations on South Cascade Glacier, Washington, April 2006

Table 26. Snow density profile measured at mass balance site S1670 near the terminus of

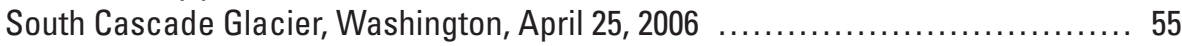

Table 27. Snow density profile measured at mass balance site S1840P-1 on South

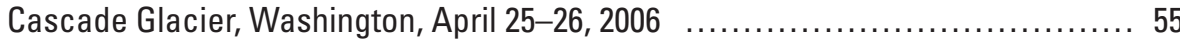

Table 28. Partial snow density profile at mass balance site S2030 on upper South Cascade Glacier, Washington, April 24, 2006. 55

Table 29. Ablation stake measurements at South Cascade Glacier, Washington, balance year 2006

Table 30. Snow depth and snow mass balance at selected locations on South Cascade Glacier, Washington, May 2007

Table 31. Snow density profile measured at mass balance site $S 1670$ near the terminus of South Cascade Glacier, Washington, May 15, 2007

Table 32. Snow density profile measured at mass balance site S1840P-1 on South Cascade Glacier, Washington, May 11, 2007

Table 33. Partial snow density profile at mass balance site S2030 on upper South Cascade Glacier, Washington, May 11, 2007

Table 34. Ablation stake measurements at South Cascade Glacier, Washington, balance year 2007

Table 35. Degree-day factors for snow and firn, and ice, computed for selected mass balance sites and periods, South Cascade Glacier, Washington, 2003-07

Table 36. Mass balance modeling periods, fitted precipitation and degree-day factors, selected fit statistics, and selected characteristics of mass balance sites on South Cascade Glacier, Washington, October 2005 to December 2007

Table 37. Surface-altitude grid with 100-meter spacing for South Cascade Glacier, Washington, 2006

Table 38. Surface-altitude grid with 100-meter spacing for South Cascade Glacier, Washington, 2007

Table 39. Selected characteristics of mass balance sites and mass balances at those sites on the dates of the glacier maximum winter snow balance and end of glacier balance year, South Cascade Glacier, Washington, balance years 2006 and 2007

Table 40. Winter, summer, and net balances of South Cascade Glacier, Washington, balance years 1953 and $1955-2007$

Table 41. Selected glaciological quantities and dates for South Cascade Glacier, balance years 2006 and 2007 


\title{
Conversion Factors, Datum, Abbreviations, and Symbols
}

\author{
Conversion Factors
}

\begin{tabular}{lll}
\hline \multicolumn{1}{c}{ Multiply } & \multicolumn{1}{c}{ By } & \multicolumn{1}{c}{ To obtain } \\
\hline millimeter $(\mathrm{mm})$ & Length & \\
meter $(\mathrm{m})$ & 0.03937 & inch (in.) \\
kilometer $(\mathrm{km})$ & 3.281 & $\begin{array}{l}\text { foot }(\mathrm{ft}) \\
\text { mile }(\mathrm{mi})\end{array}$ \\
\hline & 0.6214 & \\
\hline square kilometer $\left(\mathrm{km}^{2}\right)$ & Area & square mile $\left(\mathrm{mi}^{2}\right)$ \\
\hline & 0.3861 & \\
\hline cubic meter per second $\left(\mathrm{m}^{3} / \mathrm{s}\right)$ & Flow rate & cubic foot per second $\left(\mathrm{ft}^{3} / \mathrm{s}\right)$ \\
meter per second $(\mathrm{m} / \mathrm{s})$ & 35.31 & mile per hour $(\mathrm{mi} / \mathrm{h})$ \\
meter per day $(\mathrm{m} / \mathrm{yr})$ & 2.237 & foot per day $(\mathrm{ft} / \mathrm{yr})$ \\
millimeter per day $(\mathrm{mm} / \mathrm{d})$ & 3.281 & inch per day $(\mathrm{in} / \mathrm{d})$ \\
\hline & 0.03937 & \\
\hline kilogram $(\mathrm{kg})$ & Mass & pound avoirdupois $(\mathrm{lb})$ \\
\hline & 2.205 & \\
\hline kilogram per cubic $\mathrm{meter}\left(\mathrm{kg} / \mathrm{m}^{3}\right)$ & Density & pound per cubic foot $\left(\mathrm{lb} / \mathrm{ft}^{3}\right)$ \\
\hline & 0.06242 & \\
\hline watt per square meter $\left(\mathrm{W} / \mathrm{m}^{2}\right)$ & Energy & calorie per square centimeter \\
& $2.388 \times 10^{-5}$ & per second \\
\hline
\end{tabular}

Temperature in degrees Celsius $\left({ }^{\circ} \mathrm{C}\right)$ may be converted to degrees Fahrenheit $\left({ }^{\circ} \mathrm{F}\right)$ as follows:

$$
{ }^{\circ} \mathrm{F}=\left(1.8 \mathrm{x}^{\circ} \mathrm{C}\right)+32 \text {. }
$$

Datum

In this report "altitude" refers to height above the National Geodetic Vertical Datum of 1929 (NGVD of 1929) - a geodetic datum derived from a general adjustment of the first-order level nets of both the United States and Canada, formerly called Sea Level Datum of 1929. 
Abbreviations

\begin{tabular}{cl}
\hline Abbreviaton & \multicolumn{1}{c}{ Meaning } \\
\hline AAR & Accumulation area ratio \\
ELA & Equilibrium line altitude \\
GPS & Global positioning system \\
mWE & Meters water equivalent \\
PDO & Pacific Decadal Oscillation \\
RMSE & Root mean square error \\
SNOTEL & Snowpack Telemetry \\
SWE & Snow water equivalent \\
TIN & Triangulated irregular network \\
USGS & U.S. Geological Survey \\
UTM & Universal Transverse Mercator \\
\hline
\end{tabular}

Symbols

\begin{tabular}{|c|c|}
\hline Symbol & Meaning \\
\hline$A_{i}^{l}$ & Attribution of the mass balance at grid point $i$ to the next lower measurement site \\
\hline$A_{i}^{u}$ & Attribution of the mass balance at grid point $i$ to the next higher measurement site \\
\hline$A_{f}$ & Fractional attribution of the grid average mass balance to a given reference site \\
\hline$a_{i}$ & Daily ice melt \\
\hline$a_{s}$ & Daily snow or firn melt \\
\hline$\dot{a}$ & Ablation rate \\
\hline$b$ & Mass balance for a period beginning with time $t_{0}$ and ending with time $t_{1}$ \\
\hline $\bar{b}$ & Glacier mass balance \\
\hline$b_{\mathrm{a}}$ & Annual (water year) balance \\
\hline $\bar{b}_{\mathrm{a}}$ & Glacier annual (water year) balance \\
\hline$b_{\mathrm{n}}$ & Net balance \\
\hline $\bar{b}_{\mathrm{n}}$ & Glacier net balance \\
\hline$b_{s}$ & Summer balance \\
\hline $\bar{b}_{\mathrm{s}}$ & Glacier summer balance \\
\hline$b_{\mathrm{w}}$ & Winter balance \\
\hline $\bar{b}_{\mathrm{w}}$ & Glacier winter balance \\
\hline $\mathrm{b}_{\mathrm{m}}(\mathrm{s})$ & Measured winter snow balance \\
\hline $\bar{b}_{\mathrm{m}}(\mathrm{s})$ & Glacier measured winter snow balance \\
\hline$b_{\mathrm{w}}(\mathrm{s})$ & Maximum winter snow balance \\
\hline $\bar{b}_{\mathrm{w}}(\mathrm{s})$ & Glacier maximum winter snow balance \\
\hline$b\left(Z_{i}\right)$ & $\begin{array}{l}\text { Relation that describes mass balance, in meters water equivalent, as either varies with } \\
\text { glacier surface altitude, evaluated at altitude } Z_{i}\end{array}$ \\
\hline
\end{tabular}


Symbols-Continued

\begin{tabular}{|c|c|}
\hline Symbol & Meaning \\
\hline$c$ & Daily accumulation \\
\hline$\dot{c}$ & Accumulation rate \\
\hline$c_{0}$ & $\begin{array}{l}\text { Factor relating precipitation at a reference site to precipitation at a particular glacier } \\
\text { site }\end{array}$ \\
\hline$d_{0}, d_{1}$ & Emperical coefficients \\
\hline$D D F_{i}$ & Degree-day factor for ice melt \\
\hline$D D F_{s}$ & Degree-day factor for snow and firn melt \\
\hline$P D D$ & Positive degree days \\
\hline$m$ & Slope of a rating curve segment on a logarithmic plot \\
\hline$n$ & Number of glacier altitude grid points \\
\hline$p$ & Discharge when the quantity $\left(S-S_{0}\right)$ equals 1 \\
\hline$P_{r e f}$ & Daily precipitation at a reference site \\
\hline$q$ & Stream discharge \\
\hline$S$ & Water stage \\
\hline$S_{0}$ & Stage of effective zero stream discharge \\
\hline$T$ & Daily average air temperature \\
\hline$T_{2}$ & Daily average air temperature at 2-m height at a given mass balance site \\
\hline$T_{\text {crit }}$ & Air temperature at and below which precipitation falls as snow \\
\hline$T_{e}(Z)$ & Temperature at altitude $Z$ in the free atmosphere \\
\hline$T_{r}$ & Daily average reference temperature \\
\hline$X$ & $\begin{array}{l}\text { Position in local horizontal coordinate system along the X-axis, which increases from } \\
\text { west to east }\end{array}$ \\
\hline Y & $\begin{array}{l}\text { Position in local horizontal coordinate system along the Y-axis, which increases from } \\
\text { south to north }\end{array}$ \\
\hline$Z$ & Altitude \\
\hline$Z_{i}$ & Altitude of point $i$ in the surface-altitude grid \\
\hline$Z_{l}$ & Altitude of the next lower mass-balance reference site, in meters \\
\hline $\mathrm{Z}_{u}$ & Altitude of the next higher mass-balance reference site, in meters \\
\hline$\Gamma$ & Temperature lapse rate in the atmosphere \\
\hline$\delta T_{q}$ & Difference between $T_{2}$ and $T_{e}$ due to the glacier cooling effect \\
\hline
\end{tabular}




\title{
Modeled and Measured Glacier Change and Related Glaciological, Hydrological, and Meteorological Conditions at South Cascade Glacier, Washington, Balance and Water Years 2006 and 2007
}

\author{
By William R. Bidlake, Edward G. Josberger, and Mark E. Savoca
}

\section{Abstract}

Winter snow accumulation and summer snow and ice ablation were measured at South Cascade Glacier, Washington, to estimate glacier mass balance quantities for balance years 2006 and 2007. Mass balances were computed with assistance from a new model that was based on the works of other glacier researchers. The model, which was developed for mass balance practitioners, coupled selected meteorological and glaciological data to systematically estimate daily mass balance at selected glacier sites.

The North Cascade Range in the vicinity of South Cascade Glacier accumulated approximately average to above average winter snow packs during 2006 and 2007. Correspondingly, the balance years 2006 and 2007 maximum winter snow mass balances of South Cascade Glacier, 2.61 and 3.41 meters water equivalent, respectively, were approximately equal to or more positive (larger) than the average of such balances since 1959. The 2006 glacier summer balance, -4.20 meters water equivalent, was among the four most negative since 1959. The 2007 glacier summer balance, -3.63 meters water equivalent, was among the 14 most negative since 1959 . The glacier continued to lose mass during 2006 and 2007, as it commonly has since 1953, but the loss was much smaller during 2007 than during 2006. The 2006 glacier net balance, -1.59 meters water equivalent, was 1.02 meters water equivalent more negative (smaller) than the average during 1953-2005. The 2007 glacier net balance, -0.22 meters water equivalent, was 0.37 meters water equivalent less negative (larger) than the average during 1953-2006. The 2006 accumulation area ratio was less than 0.10 , owing to isolated patches of accumulated snow that endured the 2006 summer season. The 2006 equilibrium line altitude was higher than the glacier. The 2007 accumulation area ratio and equilibrium line altitude were 0.60 and 1,880 meters, respectively.

Accompanying the glacier mass losses were retreat of the terminus and reduction of total glacier area. The terminus retreated at a rate of about 13 meters per year during balance year 2006 and at a rate of about 8 meters per year during balance year 2007. Glacier area near the end of balance years 2006 and 2007 was 1.74 and 1.73 square kilometers, respectively.

Runoff from the basin containing the glacier and from an adjacent nonglacierized basin was gaged during all or parts of water years 2006 and 2007. Air temperature, wind speed, precipitation, and incoming solar radiation were measured at selected locations on and near the glacier. Air-temperature over the glacier at a height of 2 meters generally was less than at the same altitude in the air mass away from the glacier. Cooling of the air by the glacier increased systematically with increasing ambient air temperature. Empirically based equations were developed to estimate 2-meter-height air temperature over the glacier at five sites from site altitude and temperature at a non-glacier reference site.

\section{Introduction}

The long-term investigation and monitoring of South Cascade Glacier, Washington, are part of U.S. Geological Survey (USGS) glacier research with the objective of increasing understanding of the relation of glaciers to climate and the effects of glaciers on water resources and hydrological hazards. A keystone of the USGS efforts is the system of benchmark glaciers (Fountain and others, 1997), glaciers singled out for intensive study within distinct glacierized regions of the United States. Each benchmark glacier serves as an index site, the concerted investigation and monitoring of which is intended to provide a better understanding of the links between glaciers and climate (Hodge and others, 1998; Rasmussen and Conway, 2004 ) and effects of glaciers on water resources within the home region of the benchmark glacier (Krimmel and Tangborn, 1974; Fountain and Tangborn, 1985). Field-based measurements and analysis for benchmark glaciers include glacier mass balance and related glaciological, hydrological, and meteorological data. Glacier mass balance is the difference between annual accumulation and ablation of snow, firn, and ice averaged over the area of the glacier. 
South Cascade Glacier, the benchmark glacier for the extensively glacierized North Cascade Mountains in Washington (Post and others, 1971), is a north-northwest-facing valley glacier that occupies approximately one-third of South Cascade Lake basin near the crest of the Cascade Range (fig. 1). The USGS South Cascade Glacier dataset now spans more than 5 decades. Glaciologists and climatologists have used these data extensively in a wide range of studies, including studies of glacier dynamics (Radić and others, 2008) and of sea level rise (Dyurgerov and Meier, 1997). Mass balance data for South Cascade Glacier and other selected glaciers around the world are compiled and published periodically by the World Glacier Monitoring Service (Haeberli and others, 2007). Two other USGS benchmark glaciers, Gulkana Glacier and Wolverine Glacier, are in glacierized regions of Alaska (March, 1998 and 2003; Mayo and others, 2004). Additional information about the USGS benchmark glaciers, including bibliographies, can be accessed online (U.S. Geological Survey, 2009).

\section{Previous Work}

The USGS began intensive study of South Cascade Glacier in 1957 (Meier, 1958) and has since monitored selected glaciological variables, including glacier mass balance and glacier area, as well as selected meteorological and hydrologic variables. Photographs of the glacier taken in 1953 and 1955-1957 were used to estimate glacier mass balance for those balance years, and direct glaciological measurements were used to compute mass balance and glacier flow during balance years 1958-64 (Meier and Tangborn, 1965). The balance year is the time between successive annual minima of glacier mass. The annual minimum glacier mass typically occurs in October. Glacier mass balance studies and some related work for balance years 1965-67 are described by Meier and others (1971) and by Tangborn and others (1977). Hydrological and meteorological data for 1957-1967 are presented by Sullivan (1994). Glacier mass balance studies for balance years 1959-85 are summarized in Krimmel (1989). Mass balance studies and related work for balance years 1986-2005 are presented in detail in Krimmel (1993, 1994, 1995, 1996a, 1997, 1998, 1999, 2000, 2001, and 2002) and Bidlake and others (2004, 2005, and 2007).

Previous USGS work indicates South Cascade Glacier has been losing mass and retreating up its confining valley for more than 5 decades. In 1958, the glacier was about 3.5 kilometers $(\mathrm{km})$ long and occupied an area of $2.71 \mathrm{~km}^{2}$ (Meier and Tangborn, 1965). Net balance of South Cascade Glacier averaged -0.57 meters water equivalent (mWE) during balance years 1953-2005 and years of negative net balance outnumbered years of positive net balance by a ratio of about 2 to 1 (Bidlake and others, 2007). By 2005, the terminus of the glacier had retreated about $0.7 \mathrm{~km}$ from its 1958 position and the glacier had shrunk to an area of $1.75 \mathrm{~km}^{2}$ (Bidlake and others, 2007).
Net balance of South Cascade Glacier became more negative during the late 1980s (Josberger and others, 2007), indicating the rate of glacier thinning had accelerated. The average net balance during 1958-88 was $-0.51 \mathrm{mWE}$ and the average net balance during 1989-2005 was -0.79 mWE.

South Cascade Glacier has been a subject for several mass balance modeling investigations that commonly were aimed at describing or predicting evolution of the glacier before, during, or after the glacier observational record. Tangborn (1980) estimated winter, summer, and yearly glacier mass balances with an empirical model that employed mean May--September air temperature and total winter precipitation at a distant site in the foothills of the Cascade Range.

Tangborn (1999) developed a model similar to the 1980 model and tested it against mass balances measured at South Cascade Glacier. The newer model used daily air-temperature and precipitation observations at a lowland site and the distribution of glacier area with altitude to estimate daily mass balance as it varied with altitude on the glacier. Rasmussen and Conway (2001) developed an empirical model for estimating the winter mass balance of South Cascade Glacier from distant, upper-air meteorological observations of temperature, relative humidity, and wind speed and direction. They then estimated mass balance for the entire year by correlating observed winter balances with observed yearly balances. Rasmussen and Conway (2003) developed an empirical model to estimate summer mass balance of South Cascade Glacier, again using distant, upper-air meteorological observations, and they combined the newer model with their model for winter mass balance to estimate yearly mass balance.

Each of the previously discussed modeling investigations used air temperature to predict glacier melt. Temperaturebased techniques have been extensively used in glaciology because air-temperature data are relatively easy and inexpensive to obtain and the techniques have often proven to be as accurate as the more demanding physically based techniques that compute melt from the energy balance. Ohmura (2001) concluded that the temperature-based techniques work as well as they do because variations of air temperature at a given location tend to correlate strongly with the magnitudes of the three energy fluxes most responsible for glacier melt. Those energy fluxes and their immediate sources are down-welling long-wave radiation from the atmosphere, incoming short-wave radiation from the sun, and turbulent sensible heat from the atmosphere.

Anslow and others (2008) applied a physically based energy balance model to simulate mass balance of the glacier during parts of the 2004 and 2005 summers. An important goal of the investigation was to describe uncertainty in simulated mass balance due to uncertainties about values for key model parameters and about metrological data used in the simulations. 


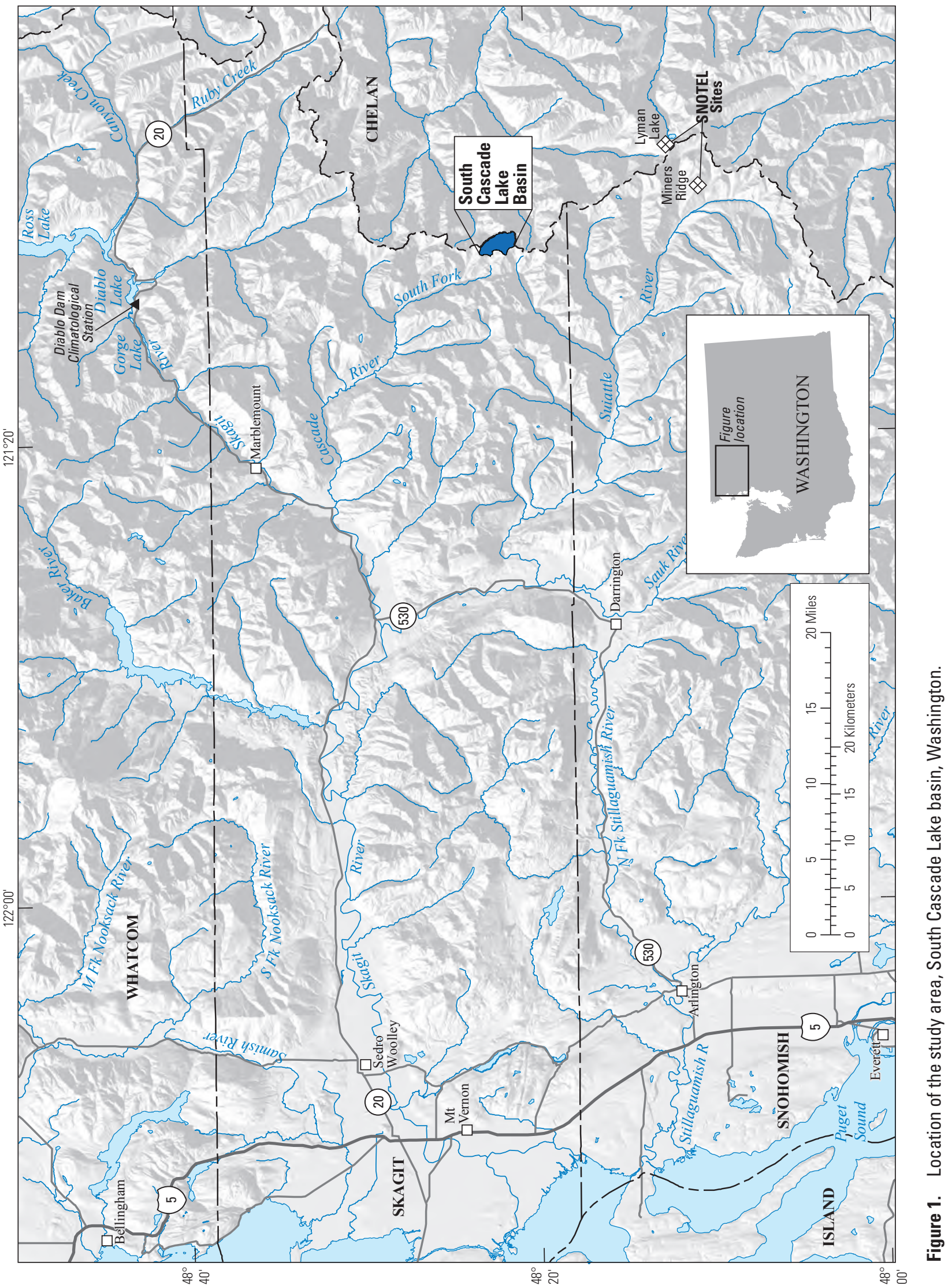




\section{Purpose and Scope}

This report describes glaciological, meteorological, and hydrological data collection at and near South Cascade Glacier during balance years 2006 and 2007, and presents the data or summaries of the data, interpretations of the data in terms of glacier change and mass balance, meteorological conditions of the glacier environment, and glacier effect on streamflow. The report also describes a technique for estimating glacier-average mass balance on the basis of balances at a network of selected sites, and presents a simple empirically based technique to estimate daily average air temperature at selected glacier sites and an empirical mass balance model that combines local glaciological and air-temperature data to estimate daily mass balance at selected sites. Previously published selected glaciological and meteorological data from balance years 2003-05 (Bidlake and others, 2005, 2007) were used in implementing the model for South Cascade Glacier.

\section{Description and Climate of Study Area}

South Cascade Glacier is in South Cascade Lake basin, at the head of the South Fork of the Cascade River, a tributary to the Skagit River that flows westerly into Puget Sound about $100 \mathrm{~km}$ from the glacier (fig. 1). The terrain that confines the glacier is extremely steep with local relief of more than $1,000 \mathrm{~m}$. Areas of the basin not covered by glacier ice or water are bedrock. The bedrock either is mantled by thin, rocky soils or is covered by talus, glacial moraines, or glacial outwash material. Stunted and shrubby conifers, heather, or other vegetation grow in the study area, and are typical of vegetation in the high North Cascade Mountains.

South Cascade Lake basin (fig. 2) has an area of $6.14 \mathrm{~km}^{2}$ and ranges in altitude from 1,613 to $2,518 \mathrm{~m}$. The area of this basin has been computed previously to be $6.02 \mathrm{~km}^{2}$ and $6.11 \mathrm{~km}^{2}$, owing to differing interpretations of the position of the drainage divide. A subbasin of the South Cascade Lake basin is the $4.46-\mathrm{km}^{2}$ Middle Tarn basin (unofficial name), which constitutes the southern two-thirds of the South Cascade Lake basin. Virtually all ice melt within South Cascade Lake basin takes place in Middle Tarn basin.

Salix Creek basin is a nonglacierized basin adjacent to South Cascade Lake basin. It has an area of approximately $0.22 \mathrm{~km}^{2}$, but its drainage divides are defined poorly. Salix Creek basin ranges in altitude from 1,587 to $2,140 \mathrm{~m}$ and predominantly is south facing.

A local geographic coordinate system for South Cascade Lake basin described by Krimmel (1994) is used in this report. The Y-axis of the coordinate system is rotated about 1.5 degrees clockwise from true north and the $\mathrm{Y}$ coordinate increases from south to north. The $\mathrm{X}$-axis is perpendicular to the $\mathrm{Y}$-axis and the $\mathrm{X}$ coordinate increases from west to east.
Distances are in meters. The $\mathrm{X}$ and $\mathrm{Y}$ coordinates can be approximately converted to Universal Transverse Mercator (UTM) zone 10 coordinates referenced to the North American Datum of 1927 by the equations:

$$
\text { UTM easting }=X \times 0.99985+642,000 \text {, }
$$

and

$$
\text { UTM northing }=Y \times 0.99985+5,355,000 \text {. }
$$

The climate of the region is maritime. Near the glacier, typical winter minimum air temperature is about $-10^{\circ} \mathrm{C}$ and typical maximum summer air temperature is about $20^{\circ} \mathrm{C}$. Most of the precipitation falls as snow during October to May. Average annual precipitation in the region is estimated to exceed $4.5 \mathrm{~m}$ in places (PRISM Climate Group, 2006). Accumulated snow on the glacier typically peaks in April or May and the amount that accumulates is strongly influenced by climate conditions in the Pacific Ocean (Walters and Meier, 1989; Mantua and others, 1997; Hodge and others, 1998; Bitz and Battisti, 1999).

For example, the Pacific Decadal Oscillation (PDO) has been recognized as a spatially coherent pattern of variation in surface temperature of the northern Pacific Ocean that has recurred on a timescale of decades since about the beginning of the 20th century (Mantua and others, 1997). The statistically derived PDO index is intended to reflect the strength and polarity of the PDO phenomenon. Statistically, the PDO index is the leading principle component in the surface temperature fields of the Pacific Ocean north of $20^{\circ}$ North latitude. The Pacific Ocean is coupled to its atmosphere and variations in the PDO index are reflected in variations in the climate of North America. During periods when the PDO index is positive, warmer than normal sea-surface temperature tends to prevail along the west coasts of North America. A positive PDO index has been associated with relatively warm and dry winters in Washington; therefore, relatively small amounts of snow accumulates on South Cascade Glacier (Josberger and others, 2007). A negative PDO index has been associated with relatively cool and moist winters and relatively large snow accumulations in Washington.

Periods of above-freezing weather typically interrupt the generally cold South Cascade Glacier winters a few times each year. Above-freezing winter air temperatures, rain, and snow melt occur most frequently on the lower glacier but they occasionally occur over the entire glacier. Precipitated and melt-liberated water infiltrates the snow pack where part or all of the water freezes to form hard, icy snow and ice layers. These layers densify the snow pack and commonly interfere with attempts to sound the thickness of the winter snow pack by probing and attempting to core the pack for snow samples. 


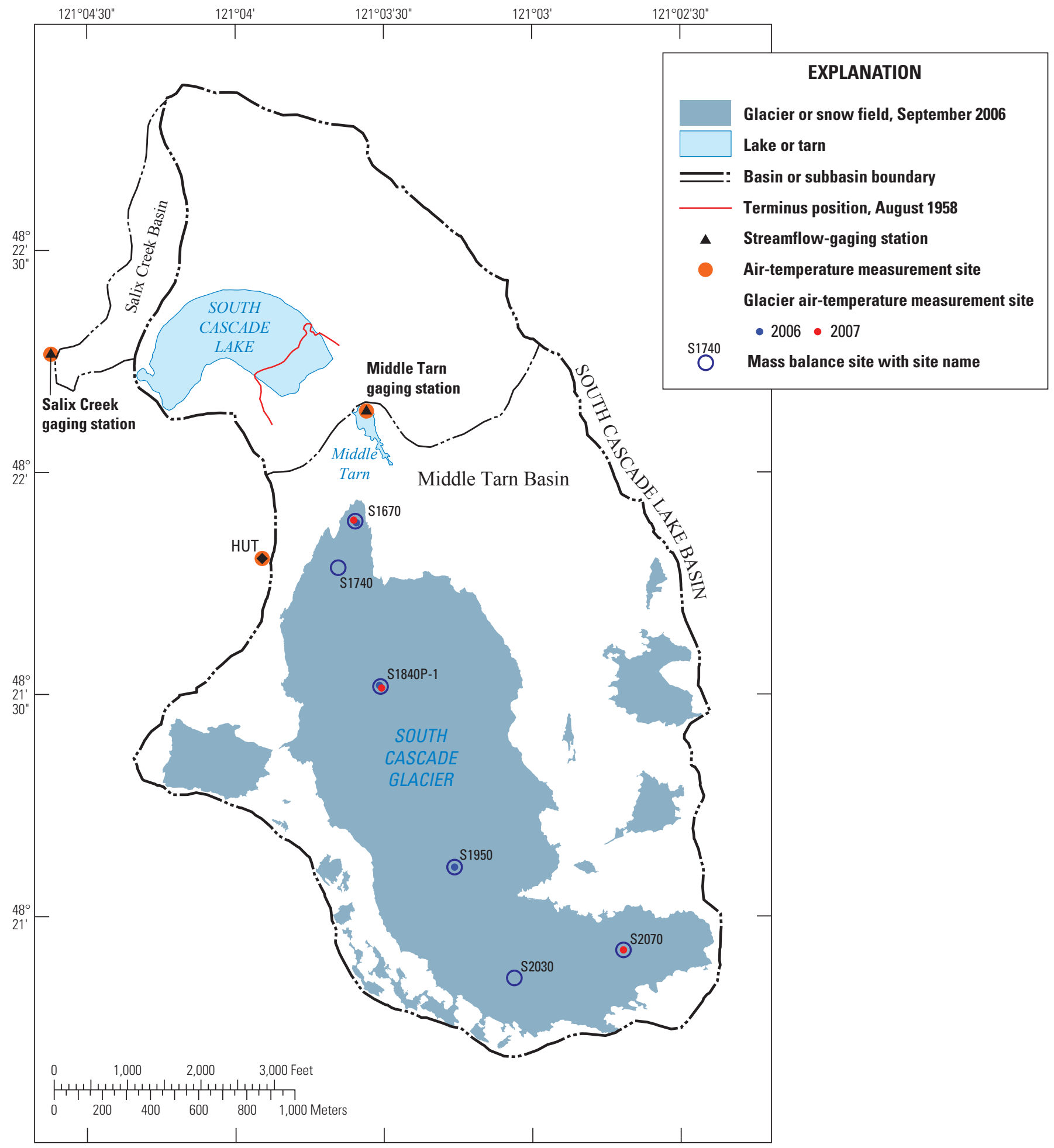

Figure 2. South Cascade Glacier and vicinity, Washington. 


\section{Study Methods}

Methods of data collection and analysis that were followed for this study were similar to those of Bidlake and others (2004, 2005, and 2007). Meteorological and hydrological data were collected predominantly using automated instrument systems. Time-series meteorological and streamflow data were based on Pacific Standard Time. Daily summaries of time-series data were constructed with each day ending at midnight. Glaciological measurements for glacier mass balance were made during intermittent site visits. Vertical aerial photographs acquired in September were used to produce a map and altitude grid of the glacier surface near the end of each balance year.

\section{Meteorological and Streamflow Data Collection}

Air temperature was measured with thermistor-based sensors at the Salix Creek and Middle Tarn gaging stations, at the Hut, and at selected locations over the glacier (fig. 2). Temperature sensors were housed in passively ventilated radiation shields. A self-adjusting sensor mount (Bidlake and others, 2005) was used to maintain air temperature sensors at a nearly constant $2.0-\mathrm{m}$ height over the glacier surface as the surface lowered during summer. Air temperature was sensed at a height of about $3.5 \mathrm{~m}$ above ground at the Salix Creek gaging station and at about $3 \mathrm{~m}$ above ground at the Middle Tarn gaging station. Air temperature and wind speed were measured over the roof of the Hut at heights of about $1.5 \mathrm{~m}$ above the roof. The Hut itself was on a narrow, steeply sloping ridge top. Air temperature at the gaging stations and at the Hut was measured every minute and the average was recorded at the end of each hour. Air temperature over the glacier was measured and recorded every 10 minutes. Daily minimum and maximum air temperatures presented in this report were the daily extremes of recorded temperature. Wind speed at the Hut was measured every minute using a cup anemometer and data were averaged and recorded at the end of each hour.

Incoming solar radiation was measured at the Hut using a thermopile-based pyranometer as a primary sensor and a photovoltaic-based pyranometer as a backup. Solar radiation measured each minute was averaged and recorded at the end of each hour. Hourly average solar radiation was set equal to 0 for hours beginning and ending during nighttime, where nighttime was distinguished from daytime on the basis of civil twilight (U.S. Naval Observatory, 2007). Daily averages of incoming solar radiation were computed for the 24-hour day.
Because of a data logger programming error, output from the primary sensor during parts of 2006 and 2007 exceeded the voltage range of the data logger when incoming solar radiation was greater than about 920 watts per square meter $\left(\mathrm{W} / \mathrm{m}^{2}\right)$, resulting in erroneous data from that sensor. The backup sensor was calibrated using data recorded from the primary sensor. Data from the backup sensor were substituted into the incoming solar-radiation record for periods when data from the primary sensor were thought to be unreliable.

Precipitation was measured at the Salix Creek gaging station (fig. 2) using an unheated tipping-bucket rain gage with a measurement resolution of 0.254 millimeters $(\mathrm{mm})$. Precipitation was totaled and recorded at the end of each hour. Because the gage was not heated or otherwise equipped to measure precipitation as snow, data are reliable only for periods when precipitation fell as rain at the Salix Creek gaging station.

Runoff from Middle Tarn basin was computed from discharge of the South Fork of the Cascade River where it empties from Middle Tarn over a mostly bedrock hydrological control. The stage of Middle Tarn was sensed with a submersible pressure transducer on the tarn bed and it was recorded by a data logger at the Middle Tarn gaging station (USGS station number 12181090) every 15 minutes. Stage recorded by the data logger was corrected as needed on the basis of intermittent stage observations that were made at a staff gage attached to a large boulder along the tarn shore.

Intermittent measurements of discharge from Middle Tarn were made to check, and if necessary, modify the rating curve describing the relation of stage to discharge for the Middle Tarn gaging station. Two combined stage and discharge measurements were made during water year 2006 and one was made during water year 2007. A water year is the 12-month period from October 1 through September 30. The water year is named for the year in which it ends.

Field measurements of stage and computations of discharge were made using English units to maintain compatibility with measuring equipment and for the convenience of data reviewers. Because the International System of Units (SI) is the primary system used in this report, however, streamflow quantities are presented in this report using SI units.

Discharge of the river from Middle Tarn was computed from the stage record by applying a rating curve that was developed or modified using intermittent measurements of stage and discharge. The rating curve was based on techniques given by Rantz and others (1982), wherein a rating curve (or a segment of a rating curve) plots as a straight line on a logarithmic graph and can be described by the equation: 


$$
q=p\left(S-S_{0}\right)^{m},
$$

where

$q$ is stream discharge, in cubic feet per second;

$p$ is discharge when the quantity $\left(S-S_{0}\right)$ equals

1 , in cubic feet per second;

$S-S_{0}$ is depth of water on the hydrological control; where

$S$ is stage, in feet; and

$S_{0}$ is equal to stage of effective zero stream discharge, in feet;

and

$m$ is slope of a rating curve segment on a logarithmic plot.

The rating curve might be applied to compute discharge directly from stage, or the stage might be "shifted" on the basis of a measured discharge that plots substantially off of the rating curve. Shifting is changing the stage applied to equation 3 from that which is measured to that which makes the equation yield discharge that closely approximates measured discharge. The most common rationale for using stage shifts is they are thought to reflect temporary changes in the hydrological control resulting from scouring and filling of sediments on the control during and after high flows.

The rating curve was developed for ice-free conditions; however, the outlet of Middle Tarn was covered with ice and snow during winter. Because there were no winter measurements of discharge to adjust the rating curve for ice- and snow-covered conditions, discharge from Middle Tarn was not computed when such conditions were thought to have existed. The water year 2007 record of stage was further truncated by an autumn flood that destroyed the gage data logger.

Runoff from nonglacierized Salix Creek basin was computed in much the same manner as for Middle Tarn basin. Salix Creek flows under the Salix Creek gaging station (USGS station number 12181200) and is controlled by a weir set on bedrock. The rating curve used for many years (Krimmel, 2002) for the Salix Creek gaging station consists of a single log-linear segment that can be described by the empirical function:

$$
q=2.71 S^{2.57}
$$

where all terms have been defined previously. One intermittent discharge measurement was made at the Salix Creek gaging station during water year 2006.

\section{Glacier Mass Balance and Related Principles}

The mass of a glacier, the combined masses of its snow and ice, is constantly changing through the operation of opposing processes of accumulation and ablation. Accumulation processes important for South Cascade Glacier are precipitation in the form of snow and avalanching or blowing of snow onto the glacier from surrounding terrain. Internal accumulation, caused by freezing of water from snow melt that has percolated into accumulations from previous years, is thought to be of small importance at South Cascade Glacier and is not considered in this report. Ablation is the loss of snow and ice from a glacier. The most important ablative processes at South Cascade Glacier likely operate at or very near the glacier surface: melting of snow and ice, and evaporation. Other much less important ablative processes operate within and at the base of the glacier, such as melting at the contact between the basal glacier ice and the underlying geologic bed, and melt as a result of the kinetic energy of englacial and subglacial flowing water. As a result of the dominant importance of surficial accumulation and ablation processes for grounded, non-calving glaciers in temperate regions, such as present-day South Cascade Glacier, mass balance can be investigated by studying snow and ice near the glacier surface.

The mass balance at a place on a glacier, $b$, for any period of time is given by the equation (Paterson, 1994):

$$
b=\int_{t_{0}}^{t_{1}}(\dot{c}+\dot{a}) d t,
$$

where

$t_{0}$ is beginning time of the period;

$t_{1}$ is ending time of the period;

$\dot{c}$ is accumulation rate, in meters water equivalent divided by time; and

$\dot{a}$ is ablation rate, in meters water equivalent divided by time.

Thus, increases in mass with time are indicated by positive $b$ and decreases in mass with time by negative $b$. All mass balance quantities in this report are presented as water-equivalent thicknesses, with the density of water assumed to equal $10^{3} \mathrm{~kg} / \mathrm{m}^{3}$. Equation 5 is evaluated in practice by measuring changes in water-equivalent thicknesses of snow, firn, and ice. Firn is residual snow that has endured at least one melt season without being transformed into ice. Mass balance of snow, firn, or ice is computed as the product of the thickness change of material gained or lost and its density expressed as a fraction of the density of water. 
Time periods of most interest for computing seasonal and longer-term mass balances of South Cascade Glacier are defined either phenomenologically or by fixed dates. The balance year is the time between successive yearly balance minima and the net balance $\left(b_{\mathrm{n}}\right)$ is the change in mass during the balance year (Anonymous, 1969). The beginning of the balance year is defined phenomenologically at the end of summer when accumulation of the winter snow pack covers the summer melt surface. The beginning of the balance year also is the time firn is formed, as residual snow from the previous winter, if any, becomes covered by fresh snow accumulation. The balance year and $b_{\mathrm{n}}$ are components of a stratigraphic system of mass balance measurement and reporting because they are defined with respect to snow, firn, and ice stratigraphic units (Mayo and others, 1972) that are analogous to stratigraphic layers in sedimentary geology. The tops of the stratigraphic units at selected times, such as firn or ice at the end of the summer melt season, are reference surfaces from which future accumulation and ablation can be gaged. The stratigraphic system is the primary system of measurement and reporting used in this report.

The balance year comprises two seasons: winter and summer. The winter season begins with the new balance year, typically in October, is dominated by accumulation, and ends at the time of the greatest yearly glacier mass. The summer season follows winter, is dominated by ablation, and ends with the conclusion of the balance year. The net balance thus can be partitioned to the winter balance $\left(b_{\mathrm{w}}\right)$, the mass balance for the winter season, and the summer balance $\left(b_{\mathrm{s}}\right)$, the mass balance for the summer season (Anonymous, 1969). References to particular seasons in this report are based on the two balance-year seasons, rather than the four astronomical seasons. Winter melting of ice and firn is thought to have a negligibly small effect on the mass balance of South Cascade Glacier, and $b_{\mathrm{w}}$ is assumed in this report to equal the maximum winter snow balance, $b_{\mathrm{w}}(\mathrm{s})$, the snow mass balance at the time of maximum snow accumulation during the balance year. The measured winter snow balance, $b_{\mathrm{m}}(\mathrm{s})$, is the winter snow balance computed from snow measurements made near the time of maximum snow accumulation (Mayo and others, 1972). The fixed-dates system of mass balance measurement and reporting used in this report is based on the water year. The water-year mass balance is termed the annual balance $\left(b_{\mathrm{a}}\right)$ in this report.

The mass balance of the entire glacier for any time period is the average of $b$ over the entire area of the glacier. Following the convention given by Mayo and others (1972), glacier mass balance quantities are indicated with an overbar in this report. For example, the glacier net balance is denoted $\bar{b}_{\mathrm{n}}$. Spatial averaging of local mass balance quantities to obtain glacier quantities is accomplished in this report by the grid-altitude technique that was modified to enhance repeatability of results among potential technique users and to simplify averaging of local mass balances to obtain glacier mass balance. The original grid-altitude technique can be summarized with the equation (Krimmel, 1996b):

$$
\bar{b}=\frac{1}{n} \sum_{i=1}^{n} b\left(Z_{1}\right)
$$

where

$Z_{1}$ is altitude of a point in a surface-altitude grid that covers the entire glacier, in meters;

$b\left(Z_{1}\right)$ is a relation that describes mass balance, in meters water equivalent, as it varies with glacier surface-altitude, evaluated at altitude $Z_{1}$; and

$n$ is the number of glacier surface-altitude grid points.

In previous reports about South Cascade Glacier, the balance-altitude relation, $b\left(Z_{i}\right)$, typically has been generated by plotting altitudes of mass balance measurement sites against the mass balances at those sites and by fitting a curve to the data by eye (Krimmel, 1993, 1994, 1995, 1996a, 1997, 1998, 1999, 2000, 2001, and 2002; Bidlake and others, 2004, 2005, and 2007). The modification for this report was to replace the balance-altitude curve with an altitude-based interpolation and extrapolation scheme, wherein mass balance at each grid point within the altitude range of the measurement sites was computed by interpolating between the sites. Mass balance at each grid point that was outside the altitude range of the measurement sites was assigned the mass balance of the measurement site closest in altitude. Prior to the interpolations and extrapolations, mass balances at any measurement sites sharing a common altitude were averaged so no more than 1 mass balance was noted for any altitude. As with the original grid-altitude technique, the glacier mass balance computed by the modified technique was the grid average mass balance, which was the average mass balance among all the grid points in the glacier surface-altitude grid. The modified grid-altitude technique could be applied with different numbers of measurement sites at different times of the year, as was the case with the original grid-altitude technique.

One property of the modified grid-index technique is mass balance attribution, which can be used to assign numerical importance of each measurement site to the computed mass balance of the glacier. The mass balance at each grid point within the altitude range defined by any two measurement sites can be attributed to the sites according to the equations:

$$
A_{i}^{l}=\frac{Z_{u}-Z_{i}}{Z_{u}-Z_{l}}
$$


where

$$
A_{i}^{u}=1-A_{l},
$$

$$
\begin{aligned}
& A_{i}^{l} \text { is attribution of the mass balance at grid point } i \\
& \text { to the next lower measurement site; } \\
& Z_{u} \text { is altitude of the next higher measurement site, } \\
& \text { in meters; } \\
& Z_{i} \text { is altitude of grid point } i \text { in the surface-altitude } \\
& \text { grid, in meters; } \\
& Z_{l} \text { is altitude of the next lower measurement site, } \\
& \quad \text { in meters; and } \\
& A_{i}^{u} \text { is attribution of the mass balance at grid point } i \\
& \quad \text { to the next higher measurement site. }
\end{aligned}
$$

Mass balance at each grid point outside the altitude range of measurement sites was attributed fully to the measurement site closest in altitude to the grid point. The sum of $A_{i}^{l}$ and $A_{i}^{u}$ over all points of the altitude grid equals the number of points in the grid. Fractional attribution of the grid average mass balance to a given measurement site $\left(A_{f}\right)$ is the sum of $A_{i}^{l}$ and $A_{i}^{u}$ to the site over the entire grid divided by the number of points in the grid. The magnitude of site attribution can be used to assess the relative importance of each measurement site to the glacier balance. Additionally, the glacier mass balance can be computed as the sum among all measurement sites of the product of site mass balance and site attribution.

The modified grid-altitude technique and the original grid-altitude technique incorporating a user-interpreted balance-altitude relation yielded similar glacier measured winter snow balances, $\bar{b}_{\mathrm{m}}$ (s), of South Cascade Glacier for 2006 and 2007. For both years, the $\bar{b}_{\mathrm{m}}$ (s) computed by the modified technique were within $0.02 \mathrm{mWE}$ of $b_{\mathrm{m}}(\mathrm{s})$ computed by the original grid-altitude technique.

Snow pack measurements near the time of maximum winter snow accumulation each year were used in conjunction with the current year surface-altitude grid to compute the glacier measured winter snow balance $\left(\bar{b}_{\mathrm{m}}(\mathrm{s})\right)$. The snow pack measurements at South Cascade Glacier over the years typically were not made at the time of maximum accumulation, owing to weather and logistical factors. For purposes of this report, the glacier maximum snow balance $\left(\bar{b}_{\mathrm{w}}(\mathrm{s})\right)$ was computed on the basis of the snow pack measurements, meteorological observations made before and after the measurements, and a mass balance model that is described later in the report. Winter melting of ice and firn probably had a negligibly small effect on the glacier winter balance $\left(\bar{b}_{\mathrm{w}}\right)$ and $b_{\mathrm{w}}(\mathrm{s})$ was assumed to equal $\bar{b}_{\mathrm{w}}$.

Two other glaciological quantities commonly reported in conjunction with mass balances are equilibrium line altitude (ELA) and accumulation area ratio (AAR). The surface of a classic mountain glacier can be divided into an accumulation area, where net balance is positive, and an ablation zone, where net balance is negative. The accumulation area of the classic mountain glacier occupies the uppermost expanses of the glacier and extends down slope to where it meets the ablation zone. The division between the accumulation area and ablation zone is the equilibrium line, where net balance is zero, and the ELA is the altitude of the equilibrium line. The AAR is the ratio of the accumulation area to the area of the entire glacier. Many mountain glaciers differ substantially from the classic glacier in that more than one accumulation area and one ablation zone can exist, or an accumulation area can be absent during any given year. The ELA commonly cannot be observed directly for glacier surfaces comprising multiple accumulation areas and ablation zones. In such instances the ELA is sometimes inferred from the relation of net balance and altitude, in which case it is the altitude where the net balance curve passes through 0 .

\section{Mass Balance Data Collection}

The six mass balance sites constituted the basic network of sites where intensive measurements were made for the purpose of computing the glacier mass balances (fig. 2). Most of the mass balance sites had been used for this purpose since balance year 2003 or before and were re-established each year at approximately the same geographic location. For this report, the sites were named according to the 2006 site altitude rounded to the nearest $10 \mathrm{~m}$. As conditions permitted, selected mass balance measurements also were made at other places on the glacier to help better understand spatial variations of mass balance.

Mass balance measurements included measurements of snow depth on the glacier near the time of the maximum winter snow accumulation, measurements of the lowering of the glacier surface due to melt during summer, and measurements of snow density. Snow depth near the time of the maximum snow accumulation was measured using a flexible probe constructed from sections of 10-mm-diameter radio antenna. The probe was used to detect and measure depth to the interface between the snow pack and the underlying melt surface that formed at the end of the previous summer. Detection was noted by a stoppage or an increase in resistance to probe penetration. The primary causes of false detection of the interface were probe stoppage by ice layers formed within the snow pack and a lack of a notable change in resistance as the probe penetrated firn at the base of the snow pack. Such false detections could lead to errors in measured snow depth of $1 \mathrm{~m}$ or more, particularly on the upper glacier where ice layers were most persistent and where the snow pack was underlain by firn. Because of the risk of false detections of the interface beneath the snow pack, the pack typically was cored in a few places to verify its thickness. Ablation stakes placed during previous years sometimes endured and became visible during a later summer. Records from the old stakes sometimes could be used to 
establish the approximate height of the previous melt surface under the snow pack. The previous melt surface that lay under the snow pack typically was uneven and rough and snow depth measured by probing to that surface commonly varied by as much as $0.3 \mathrm{~m}$ within horizontal distances of $1 \mathrm{~m}$ or less. Because of those variations, snow depth generally was measured multiple times and averaged, particularly at ablation stakes sites.

Measurements of surface-height changes during summer were made using ablation stakes installed in holes melted through the snow and ice with a steam drill. Stakes as long as $12 \mathrm{~m}$ were constructed from $2.0-\mathrm{m}$-long sections of 32-mm-diameter aluminum tubing. The bottom of each stake was fitted with a wooden plug to reduce the amount by which the stake would sink into the glacier under the force of gravity. Lowering and rising of the glacier surface at the stakes due to ablation and accumulation was determined from repeated measurements of the exposed stake length. The glacier surface usually was rough and uneven. When measuring the height of the rough surface on an ablation stake, an ice axe or similar straight object at least $0.5 \mathrm{~m}$ in length was laid at the base of the stake and at a height judged to be the average height of the surface within a few meters of the stake. Mass balances at ablation stakes were computed from changes in glacier surface height on the stakes and by the thicknesses and densities of materials gained or lost.

Snow density was measured at selected times and mass balance sites. Snow samples were taken from the wall of a pit or extracted with either a coring auger or a specially designed snow corer. Samples taken from a pit wall were obtained using a sampling tube that was pressed or pounded into the snow. Inside diameter of the sampling tube was $72.3 \mathrm{~mm}$. The coring auger produced cores $76.3 \mathrm{~mm}$ in diameter. The auger easily cut through hardened snow and ice layers, but parts of the cores sometimes would drop out of the bottom of the auger barrel during retrieval. Re-capturing the cores was difficult and sometimes parts of the cores were unusable. The specially designed corer produced a 60.0-mm-diameter core sample (Philip Taylor, Taylor Scientific Engineering, Seattle Wash., written commun., May 2003). The rim of the bottom end of the corer was serrated and a sawing motion was used to penetrate the snow. Core samples were consistently retrieved but the corer did not penetrate hard snow or ice layers.

Snow density varies by season and from year to year. To reduce the number of time-consuming and labor-intensive density measurements, density estimation schemes developed on the basis of long-term experience at South Cascade Glacier were used to estimate snow density at locations and times when density was not measured. Krimmel (1999) observed that the density of late-winter snow packs on South Cascade Glacier tends to vary with snow pack thickness and altitude. Thicker snow packs tend to be more dense as a whole than thinner snow packs because the lower part of the pack is compacted by the mass of the snow overburden.
Higher-altitude snow packs tend to be less dense than lower-altitude snow packs of about the same thickness. A plausible explanation for this is the higher-altitude snow is subjected to fewer rain-on-snow and other weather events that promote metamorphosis and densification. Melting snow near the surface of the snow pack or rain also provide water that can percolate and freeze deeper in the pack and thereby increase the bulk density of the pack. Possibly as a result of whether compaction or weather-induced densification has dominated during any given winter, late-winter or early summer snow pack density has been observed to decrease with increasing altitude (Krimmel, 1993, 1995, 1997, 2002) or to increase with increasing altitude (Krimmel 1996, 1999; Bidlake and others, 2004, 2005). Bidlake and others (2007) reported that snow density in early summer 2005 increased with increasing altitude between a site near the terminus and site S1840P-1 and it decreased with increasing altitude between sites S1840P-1 and S2030. These observations support the notion that density evolution of snow on South Cascade Glacier is complex and in need of more investigation. For this report, density of the late-winter or early summer snow pack was measured at selected sites and was assumed to change linearly with altitude between the measurement sites. Density of snow at places outside of the altitude range of the density measurement sites was assumed to equal the density at the measurement site closest in altitude.

Density of snow that accumulated the previous winter increases during summer, when it is termed residual snow, and density of residual snow was assumed to increase from its late-winter or early summer value on a trajectory that would bring it to 0.58 by the end of the balance year (Bidlake and others, 2004). Density of the snow that accumulated during summer, termed new snow, was assumed to equal 0.5 . Density of firn less than 1 year old was estimated to be 0.6 and density of older firn was estimated to be 0.7 . Estimated density of ice was 0.9 .

\section{Photogrammetric Measurements and Glacier Mapping}

Color vertical aerial photographs of South Cascade Lake basin were acquired on September 28, 2006, and similar photographs of part of the basin were acquired September 26, 2007. In each case, an aerial camera equipped with a $152-\mathrm{mm}$ focal length lens was used; film width was $230 \mathrm{~mm}$. The camera was mounted in an airplane that flew longitudinally along the glacier. The nominal scale of the photographs was 1:12,000. Images scanned from the photograph negatives were analyzed using a digital photogrammetry system to produce stereo models of the surface of the glacier and of nearby terrain. The stereo models were oriented to the local network of horizontal and vertical controls, where the horizontal coordinates were expressed as their UTM equivalents. 
Measurements made in the stereo models were used to delineate the glacier and adjacent snowfields, to produces surface altitude grids, and to locate and map selected features in the UTM coordinate system.

An initial step in creating surface altitude grids was to model glacier and terrain surface geometries using a triangulated irregular network (TIN) in which a surface is represented by a network of adjacent and variably sized triangles. Each triangle vertex, termed a node, is defined by the 3-dimensional coordinates of a point on the surface. For this report, TIN nodes were defined by the measured horizontal and vertical coordinates at selected points on the surface of the glacier or the terrain. An automated component of the digital photogrammetry system was programmed to select and stereometrically measure altitude of node points. Nominal inter-nodal spacing was $2-\mathrm{m}$. This automated coordinate measurement depended on the system being able to search for and find correlations among features appearing in both images of a stereomodel. Relatively featureless images, such as those of recent snow or areas in dark shadows, sometimes confounded the correlation search, in which case no coordinates were returned by the automated process. In relatively featureless parts of images, node points were manually selected and measured by a photogrammetrist, if possible. Inter-nodal distance between manually selected node points typically was on the order of tens of meters.

Two rectangular surface-altitude grids of regular but differing grid-point spacing were created from the TIN for each year. A 2-m-spaced grid was populated by digitally superimposing the grid framework on the TIN and assigning altitudes from the TIN to coincident grid points. Grid-point UTM coordinates then were converted to their equivalents in the previously described local system using equations 1 and 2 and the grid data were re-gridded to achieve an even 2-m spacing in the local system. Areas of a grid were blanked that represented areas outside of the area of interest or areas where measured surface altitudes were unreliable. An irregularly shaped, 100-m-spaced grid for the glacier only was created by re-sampling the 2-m-spaced grid. The less detailed 100 -m-spaced grid was used primarily for computation of glacier-average mass balance quantities and for publication of essential surface-altitude information at the page size used in this report.

Horizontal positions of mass balance sites and snow probing locations were estimated with a hand-held global positioning system (GPS) receiver. Local coordinates were computed from UTM northing and easting coordinates read from the GPS receiver. Surface altitude of each coordinate pair was then obtained using photogrammetric measurements. Typical horizontal accuracy of coordinates obtained with GPS receiver was on the order of $7 \mathrm{~m}$. As a result, positions of snow-probing, density-measurement, and ablation stake locations that were associated with a mass balance site were all assigned the position of the ablation stake, even though the individual locations could have been separated by as much as several meters.

\section{Mass Balance Modeling}

The most critical times of the year for the mass balance program at South Cascade Glacier were the times of maximum and minimum glacier mass. Only rarely could measurements be made precisely at those critical times because of logistical and safety considerations and because the mass balance extremes at individual sites and of the glacier as a whole often did not occur on the same date. The purpose of the mass balance model described in this report was to combine selected meteorological and glaciological observations to estimate daily mass balance at selected glacier sites near the critical times. Averaging daily modeled mass balances at selected sites over the area of the glacier would yield daily time series of glacier mass balances from which important glacier mass balances and the dates of their occurrences could be computed.

The glacier at any given site was conceptualized as consisting of as many as three layers, with snow on the top, ice on the bottom, and firn in between. The conceptual structure did not distinguish thin ice layers or lenses within the snow or firn from the snow or firn of the model layers because ice was thought to account for only a small fraction of the mass in snow and firn layers at South Cascade Glacier. In the model, snow or firn layers might not always be present, such as when glacier ice was exposed at the surface.

The model computed daily snow accumulation using the equations:

$$
c=c_{0} P_{r e f} \quad\left(T_{e} \leq T_{\text {crit }}\right),
$$

and

where

$$
c=0 \quad\left(T_{e}>T_{\text {crit }}\right),
$$

$c$ is daily accumulation, in meters water equivalent;

$c_{0}$ is a factor relating precipitation at a reference site to precipitation at a particular glacier site, dimensionless;

$P_{r e f}$ is daily precipitation at the reference site, in meters;

$T_{e}$ is daily average temperature of the air mass over South Cascade Lake basin at the altitude of the site of interest, in degrees Celsius; and

$T_{\text {crit }}$ is air temperature at and below which precipitation falls as snow, in degrees Celsius. 
Daily melt of the snow, firn, or ice layer exposed at the surface was modeled using an air-temperature-based approach (Hock, 2003), where daily melt was computed using the equations:

$$
\begin{gathered}
a_{s}=D D F_{s} \times P D D, \\
a_{i}=D D F_{i} \times P D D,
\end{gathered}
$$

where

$a_{s}$ is daily snow or firn melt, in meters water equivalent;

$a_{i}$ is daily ice melt, in meters water equivalent; $D D F_{s}$ is degree-day factor for snow and firn melt, in meters water equivalent per positive degreeday;

$D D F_{i}$ is degree-day factor for ice melt, in meters water equivalent per positive degreeday; and

$P D D$ is positive degree-days, in degrees Celsius times day; and

where

$$
\begin{aligned}
& P D D=T \quad(T>0), \\
& P D D=0 \quad(T<=0),
\end{aligned}
$$

$T$ is daily average air temperature.

The model was initialized for a given site by specifying initial mass balances of snow, firn and ice, the water-equivalent thickness of the firn layer, and initial values for the precipitation factor $c_{0}$, and the degree-day factors $D D F_{s}$ and $D D F_{i}$. The mass balance of the snow layer was the water-equivalent thickness of the layer. If firn was present but indefinitely thick at a particular site, firn-layer thickness in the model was set to an arbitrary, large value (for example, $100 \mathrm{~m}$ ). An assigned water-equivalent thickness of 0 for the firn layer indicated that firn was not present. For each day of a simulation, the model first computed snow accumulation using equations 9 and 10 and updated the mass balance of the snow layer, it then computed the PDD for the day using equations 13 and 14, and it finally computed melt using equations 11 or 12 , and updated the mass balances of the snow, firn, and ice layers. If all the snow or firn melted before the PDD for the day was consumed, remaining PDDs were applied to melt the next lower layer. Given the intended use of the model for short-term mass balance estimates, the ice layer could not be increased in thickness or exhausted (the model did not simulate ice formation or de-glacierization). The model also did not explicitly create firn from residual snow. The mass balance and water-equivalent thickness of the firn layer specified at initialization thereafter could only decrease.
The model tracked daily mass balances of the snow, firn, and ice layers. The total daily mass balance was equal to the sum of the three individual mass balances.

The Miners Ridge snowpack telemetry (SNOTEL) site was the reference site for daily precipitation (fig. 1; National Water and Climate Center, 2009). The Miners Ridge site was selected because it was relatively close (within about $20 \mathrm{~km}$ ) to South Cascade Glacier, the site altitude $(1,862 \mathrm{~m})$ was similar to that of the glacier and because daily data summaries, like the daily summaries in this report, were computed for the 24-hour day ending at midnight. Precipitation at the Miners Ridge SNOTEL site was measured using a large storage-type gage. The model was used to simulate mass balance at each of the six mass balance sites. Air temperature was measured directly at each site or was estimated on the basis of air temperature recorded at the Hut using techniques presented later in this report. The air temperature equal to or less than the temperature at which precipitation fell as snow $\left(T_{\text {crit }}\right)$ was set to $2^{\circ} \mathrm{C}$ (Conway and others, 1999).

The three adjustable factors of the mass balance model, $c_{0}, D D F_{s}$ and $D D F_{i}$, were not statistically independent of each other because the appearance time of firn or ice tended to depend on the modeled snow accumulation and melt rates that the factors governed. Because of the interdependence, the model used for this report could be set to closely match measured mass balances using different combinations of factor values, including some combinations with physically implausible values for the degree-day factors. These latter combinations were eliminated by developing ranges of allowable variation for $D D F_{s}$ and $D D F_{i}$ that were used to constrain the factors during model calibration.

The allowable $D D F_{s}$ and $D D F_{i}$ ranges were developed by analyzing the degree-day factors separately and in isolation from accumulation and mixed melt of snow, firn, and ice. Sitespecific mass balance and glacier air-temperature data from 2003 to 2007 were filtered to select periods during which little or no snow accumulation occurred and during which either snow and firn melt occurred or ice melt occurred, but not both. Periods were selected on the basis of mass balance and air-temperature data collected during 2003 to 2005 (Bidlake and others, 2005 and 2007) and similar data for 2006-07 that are described by this report. The degree-day factors $D D F_{s}$ and $D D F_{i}$ each were computed by solving equation 11 or equation 12, respectively. Accumulation was not directly measured at any of the mass balance sites and a proxy for accumulation, termed here potential accumulation, was used to eliminate data for periods when accumulation affected the melt coefficients. Potential accumulation was computed as the sum of precipitation at the Miners Ridge SNOTEL site during days when the estimated atmosphere temperature at the altitude at a given mass balance site was equal to or less than $T_{\text {crit }}$. Plots of computed degree-day factors against potential accumulation were viewed to screen and remove data from periods when summer snow accumulation likely affected the 
factors. During calibration of the full mass balance model to best fit mass balance observations of balance years 2006 and 2007, which included periods of accumulation and mixed melt of snow, firn, and ice, each degree-day factor generally was varied within 1 standard deviation of the mean computed in isolation from accumulation and mixed melt. A degree-day factor was varied outside of this range at a given site only if a smaller or larger factor for the site was present in the filtered data set.

The model was initialized for each mass balance site at South Cascade Glacier by setting the precipitation factor $c_{0}$ to 1 and by setting the degree-day factors $D D F_{s}$ and $D D F_{i}$ to the means of those from periods selected to constrain the allowable ranges. The model was then calibrated against measured 2007 and 2007 mass balances by adjusting the precipitation factor $c_{0}$ and the degree-day factors $D D F_{s}$ and $D D F_{i}$. The precipitation factor was adjusted with the single constraint that it always was greater than 0 and the degree-day factors were varied within the limits described previously. Because the overall objective of mass balance modeling was to best estimate site balances at critical times of the glaciological year, model coefficients were adjusted primarily to match modeled balances with mass balances measured near the critical times and secondarily to minimize the root-mean-square error (RMSE) of modeled balances. Sample size for each simulation was the number of measured snow, firn, or ice mass balance quantities for which there were corresponding modeled balances.

\section{Results and Discussion}

The North Cascade Range in the vicinity of South Cascade Glacier accumulated roughly average winter snow packs during water years 2006 and 2007. Maximum snow water equivalent (SWE) at the Miners Ridge SNOTEL site (fig. 1) during 2006 was $1.50 \mathrm{~m}$, which was 9 percent greater than the average water year maximum for that site (years of record 1989-2007; National Water and Climate Center, 2009). Maximum SWE at the Miners Ridge site during 2007 was $1.34 \mathrm{~m}$, which was 3 percent less than the average water year maximum. The Miners Ridge site is west of the crest of the Cascade Range at an altitude of 1,862 m. The Lyman Lake SNOTEL site is east of the crest at an altitude of $1,823 \mathrm{~m}$. Precipitation and snow accumulation typically are greater at the Lyman Lake site than at the Miners Ridge site. Maximum SWE at the Lyman Lake site during 2006 was 1.79 m, which was 8 percent greater than the average water year maximum for that site (years of record 1980, 1984-2007). Maximum 2007 SWE was $1.82 \mathrm{~m}$, which was 10 percent greater than the average water year maximum.

\section{Water Years 2006 and 2007 Meteorological and Streamflow Conditions}

Water year 2006 at South Cascade Lake basin was as a whole slightly cooler than water year 2005, but the 2006 summer was warmer. Air temperature at the Hut averaged $2.4^{\circ} \mathrm{C}$ (table 1$)$, which was $0.2^{\circ} \mathrm{C}$ less than the previous year. The minimum recorded air temperature at the Hut during water year 2006 was $-19.1^{\circ} \mathrm{C}$ on February 17 and the maximum was $26.1^{\circ} \mathrm{C}$ on July 21 (fig. 3). February was the coldest month at the Hut, when air temperature averaged $-5.8^{\circ} \mathrm{C}$, and July was the warmest month, when air temperature averaged $12.2^{\circ} \mathrm{C}$. Average annual air temperature at the Middle Tarn gaging station was $3.2^{\circ} \mathrm{C}$ (table 2), which was $0.4^{\circ} \mathrm{C}$ less than the previous year. Animal-caused damage to the air temperature sensor at the Salix Creek gaging station resulted in loss of data during parts of the water year (table 3 ), but temperature there was less than during water year 2005 for 7 of the 9 months of complete records. Most annual melt typically occurs during June to September and air temperature at the Hut averaged $10.1^{\circ} \mathrm{C}$ for those months, which was $2{ }^{\circ} \mathrm{C}$ warmer than June-September 2005 and the warmest June-September since 2003. The warmest June-September for which sufficient data are available was in $1987\left(11.2^{\circ} \mathrm{C}\right)$.

Water year 2007 at South Cascade Lake basin was cooler than water year 2006, particularly during summer. Average annual air temperature at the Hut was $1.8^{\circ} \mathrm{C}$ (table 4$)$, which was $0.6^{\circ} \mathrm{C}$ less than the previous year. The minimum recorded air temperature at the Hut during water year 2007 was $-14.6^{\circ} \mathrm{C}$ on November 28 and the maximum was $24.7^{\circ} \mathrm{C}$ on July 11 (fig. 4). November was the coldest month at the Hut, when air temperature averaged $-4.3^{\circ} \mathrm{C}$. July was the warmest month at the Hut, when air temperature averaged $12.6^{\circ} \mathrm{C}$. Damage from flooding at the Middle Tarn gaging station resulted in loss of most of the station data (table 5). Animal-caused damage to the air temperature sensor at the Salix Creek gaging station again resulted in loss of data during parts of the water year (table 6). Air temperature at the Salix Creek gaging station in water year 2007 was less than during water year 2006 for 6 of the 9 months of complete records. Air temperature during June-September 2007 at the Hut averaged $8.5^{\circ} \mathrm{C}$, which was $0.4^{\circ} \mathrm{C}$ warmer than June-September 2005 but $1.6^{\circ} \mathrm{C}$ cooler than June-September 2006. The coolest temperature during June-September for which sufficient data are available was $1964\left(6.2^{\circ} \mathrm{C}\right)$.

The air temperature sensors on the glacier were installed in late April 2006 and the sensor at mass balance site S1840P-1 operated through the end of the water year (figs. 2 and 5). The sensors at sites S1670 and S1950 operated until late September. During April 26 to September 23, when all three sensors were operating, 2-m-height air temperature averaged $6.3^{\circ} \mathrm{C}$ at site $\mathrm{S} 1950,6.1^{\circ} \mathrm{C}$ at site $\mathrm{S} 1840 \mathrm{P}-1$, and $8.0^{\circ} \mathrm{C}$ at site $\mathrm{S} 1670$ (tables 7-9). 
Table 1. Daily maximum, minimum, and average of hourly average air temperature at the Hut, 1,842 meters altitude, near South Cascade Lake basin, Washington, water year 2006.

[Abbreviations: Max, maximum; Min, minimum; Avg, average]

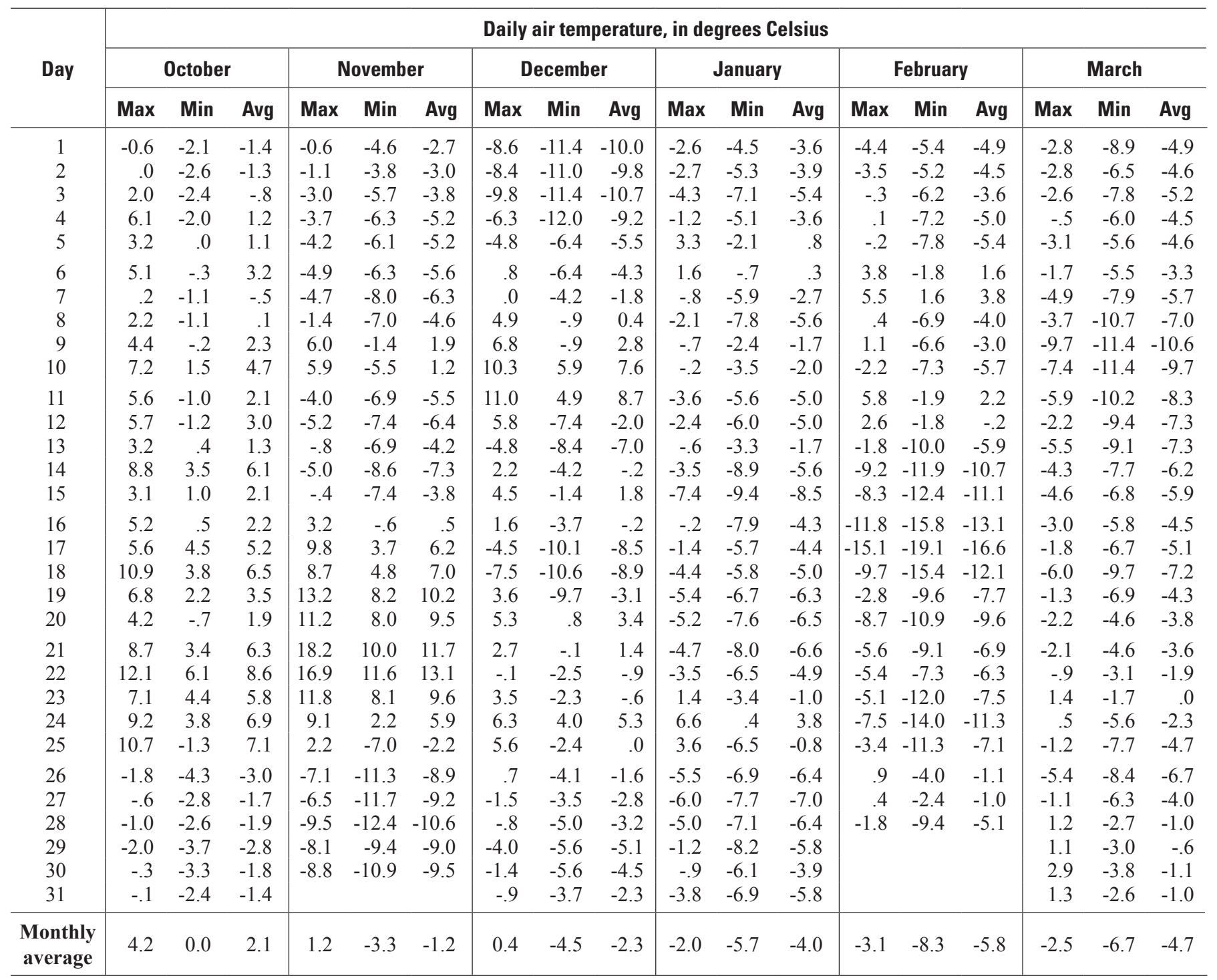


Table 1. Daily maximum, minimum, and average of hourly average air temperature at the Hut, 1,842 meters altitude, near South Cascade Lake basin, Washington, water year 2006.-Continued

[Abbreviations: Max, maximum; Min, minimum; Avg, average]

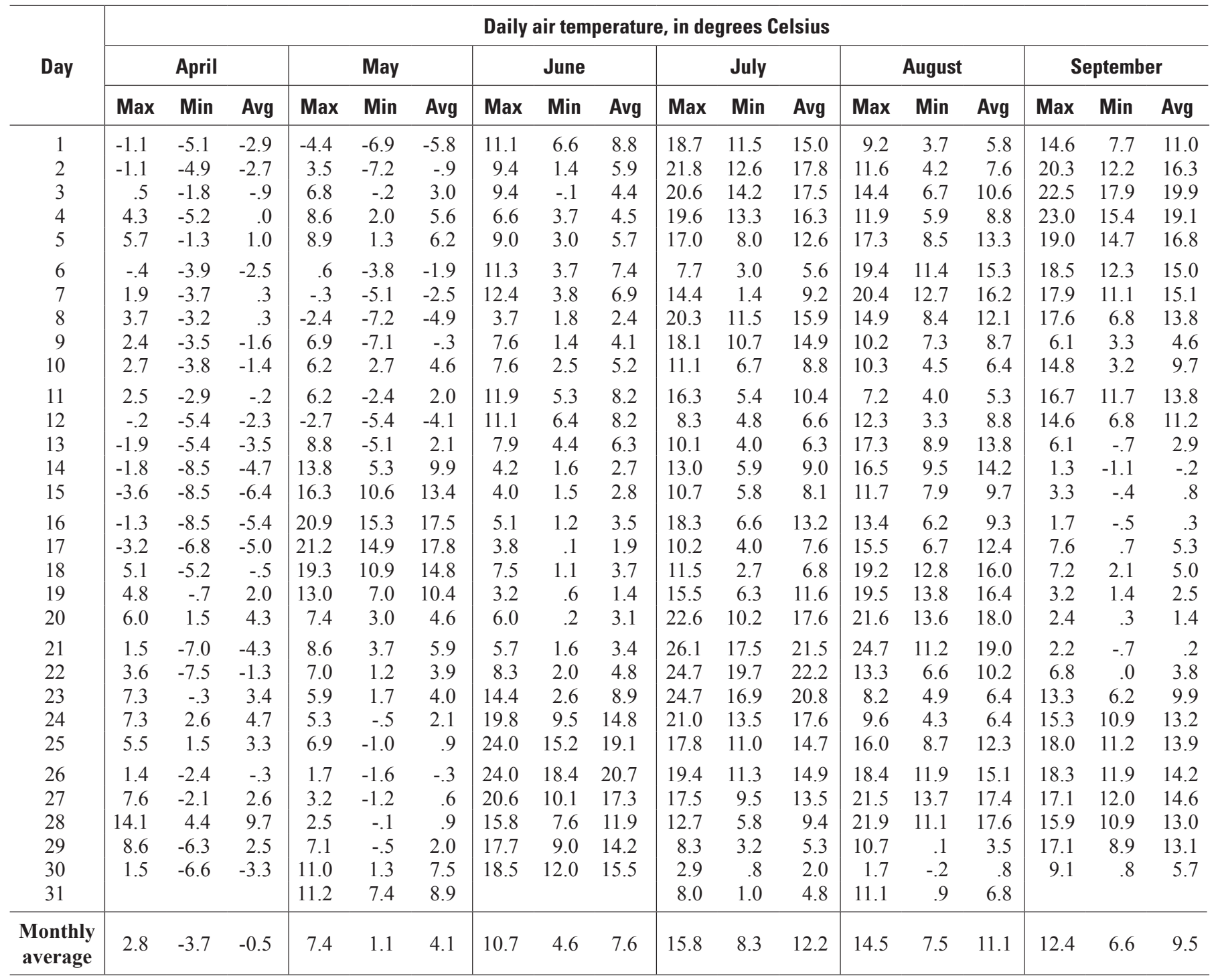


Table 2. Daily maximum, minimum, and average of hourly average air temperature at the Middle Tarn gaging station, 1,631 meters altitude, Middle Tarn basin, Washington, water year 2006.

[Abbreviations: Max, maximum; Min, minimum; Avg, average]

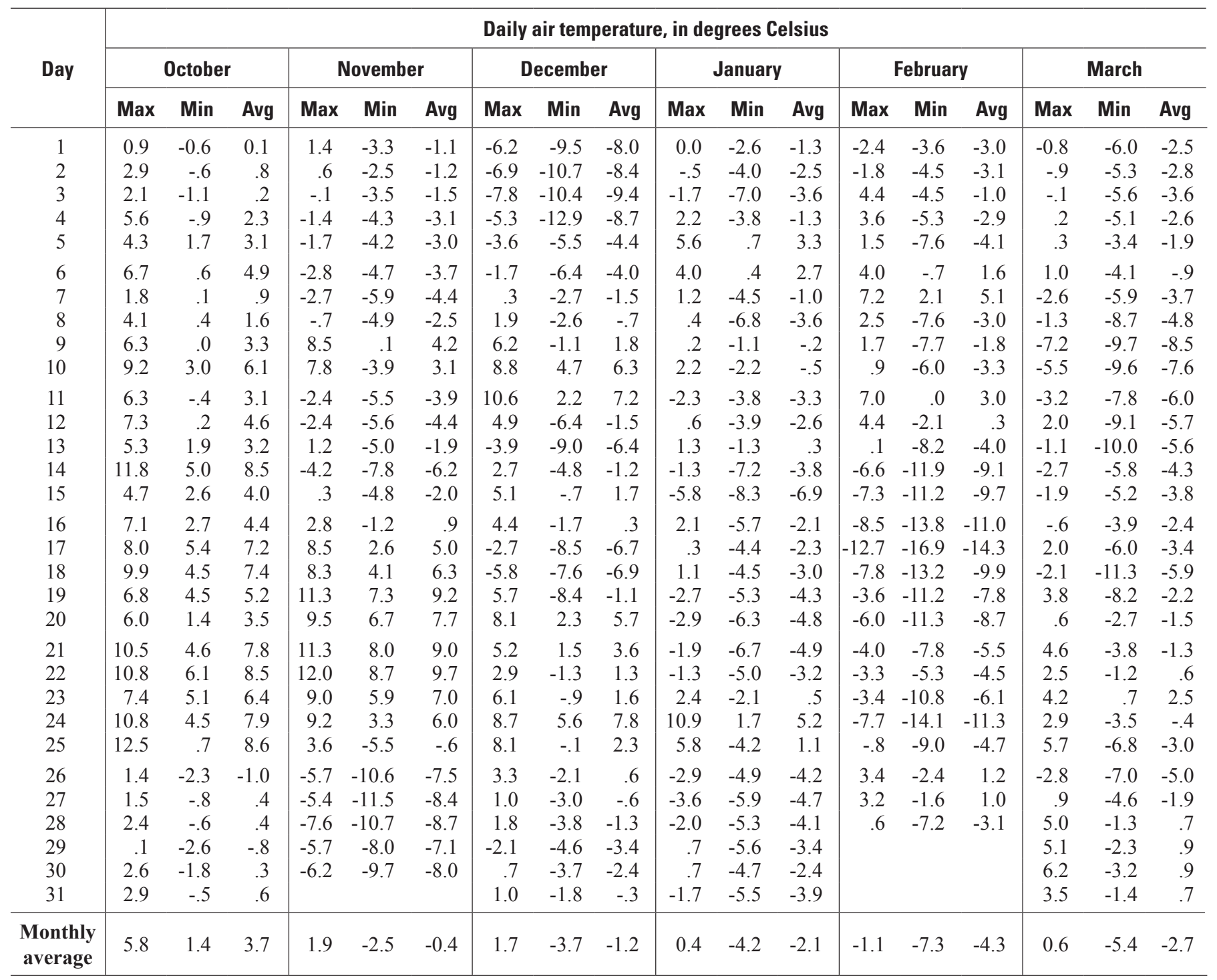


Table 2. Daily maximum, minimum, and average of hourly average air temperature at the Middle Tarn gaging station, 1,631 meters altitude, Middle Tarn basin, Washington, water year 2006.-Continued

[Abbreviations: Max, maximum; Min, minimum; Avg, average]

\begin{tabular}{|c|c|c|c|c|c|c|c|c|c|c|c|c|c|c|c|c|c|c|}
\hline \multirow{2}{*}{ Day } & \multicolumn{18}{|c|}{ Daily air temperature, in degrees Celsius } \\
\hline & Max & Min & Avg & Max & Min & Avg & Max & Min & Avg & Max & Min & Avg & Max & Min & Avg & Max & Min & Avg \\
\hline 1 & 1.2 & -4.1 & -1.4 & -2.8 & -9.0 & -4.3 & 13.5 & 6.4 & 9.0 & 19.4 & 9.9 & 13.1 & 11.3 & 5.2 & 7.7 & 17.1 & 9.6 & 12.9 \\
\hline 2 & 1.3 & -7.0 & -1.2 & 8.7 & -7.3 & -.1 & 9.8 & 3.5 & 7.2 & 17.8 & 11.1 & 14.2 & 13.7 & 5.0 & 8.9 & 18.3 & 13.9 & 15.9 \\
\hline 3 & 3.4 & -.7 & 1.0 & 8.8 & 1.3 & 4.4 & 9.2 & 1.6 & 5.4 & 17.1 & 11.5 & 14.3 & 16.2 & 6.4 & 10.4 & 21.4 & 14.4 & 18.0 \\
\hline 6 & 4.6 & -3.5 & -.4 & 1.9 & -2.6 & -.3 & 10.5 & 3.3 & 6.8 & 7.6 & 4.2 & 6.0 & 20.3 & 10.1 & 13.6 & 17.7 & 10.8 & 13.0 \\
\hline 7 & 4.8 & -3.4 & 2.0 & 2.0 & -3.8 & -.7 & 8.8 & 3.5 & 5.5 & 15.6 & 2.3 & 8.7 & 21.4 & 11.3 & 14.7 & 15.6 & 9.0 & 12.3 \\
\hline 8 & 5.4 & -.9 & 2.3 & -1.9 & -6.6 & -3.9 & 3.9 & 2.0 & 3.1 & 18.6 & 10.2 & 13.3 & 16.9 & 8.2 & 12.6 & 15.4 & 8.1 & 12.8 \\
\hline 9 & 6.3 & -2.9 & .7 & 5.6 & -7.9 & -.5 & 7.2 & 2.2 & 4.5 & 17.4 & 11.3 & 13.4 & 11.0 & 7.3 & 9.4 & 8.1 & 5.1 & 6.3 \\
\hline 10 & 10.9 & -3.1 & .8 & 8.6 & 1.7 & 6.0 & 8.2 & 3.0 & 5.4 & 13.4 & 6.8 & 10.4 & 9.8 & 6.0 & 7.2 & 12.6 & 3.5 & 8.5 \\
\hline 11 & 7.6 & -3.1 & 1.5 & 6.6 & -.3 & 3.4 & 11.2 & 5.3 & 8.0 & & 6.6 & 10.3 & 9.1 & 5.3 & 6.8 & 16.3 & 10.1 & 12.2 \\
\hline 16 & 1.8 & -6.4 & -3.5 & 14.1 & 10.4 & 13.1 & 7.4 & 3.0 & 5.7 & 17.5 & 6.6 & 11.4 & 15.3 & 6.0 & 9.7 & 3.1 & .7 & 1.9 \\
\hline 17 & 2.5 & -6.1 & -2.7 & 15.5 & 11.7 & 13.6 & 6.1 & 1.5 & 3.4 & 12.0 & 5.6 & 8.8 & 17.7 & 6.3 & 11.4 & 9.7 & 1.4 & 5.9 \\
\hline 18 & 9.9 & -6.0 & .7 & 14.3 & 8.7 & 11.5 & 8.7 & 8 & 4.4 & 13.6 & 4.5 & 8.1 & 20.0 & 10.7 & 14.1 & 8.1 & 3.9 & 6.4 \\
\hline 19 & 6.6 & -.1 & 3.8 & 13.8 & 6.2 & 9.1 & 5.5 & 2.0 & 3.3 & 14.3 & 5.1 & 10.2 & 21.4 & 11.8 & 15.0 & 4.8 & 3.0 & 4.0 \\
\hline 20 & 8.8 & 2.4 & 5.7 & 6.8 & 3.5 & 5.4 & 8.0 & 1.7 & 4.6 & 17.3 & 9.2 & 14.2 & 18.6 & 11.1 & 14.8 & 4.3 & 2.8 & 3.4 \\
\hline 21 & 2.5 & -6.2 & -2.2 & 10.7 & 3.5 & 7.1 & 7.7 & 2.7 & 4.9 & 20.8 & 17.3 & 19.1 & 18.7 & 11.2 & 15.6 & 3.9 & .8 & 1.8 \\
\hline 22 & 6.9 & -7.6 & .7 & 9.4 & 2.3 & 5.6 & 9.9 & 3.3 & 5. & 19.9 & 16.1 & 18.3 & 15.4 & 7.5 & 10.9 & 9.3 & 1.2 & 4.9 \\
\hline 23 & 9.5 & 1.6 & 5.6 & 7.1 & 2.4 & 5.0 & 12.8 & 3.1 & 7.7 & 25.5 & 15.5 & 18.5 & 10.4 & 6.1 & 7.8 & 12.8 & 5.8 & 9.2 \\
\hline 24 & 9.8 & 3.5 & 6.3 & 6.3 & 1.5 & 3.9 & 14.6 & 7.5 & 11.5 & 22.4 & 12.4 & 16.8 & 9.3 & 5.5 & 7.2 & 16.0 & 9.3 & 12.6 \\
\hline 25 & 9.6 & 1.9 & 4.8 & 9.8 & .1 & 2.7 & 16.6 & 12.6 & 14.6 & 19.8 & 10.6 & 14.6 & 18.1 & 7.6 & 11.8 & 15.5 & 10.2 & 12.2 \\
\hline 26 & 3.6 & -1.1 & 1.0 & 3.1 & -.3 & .9 & 18.5 & 13.8 & 15.9 & 21.2 & 10.4 & 14.3 & 19.4 & 10.0 & 13.6 & 15.3 & 10.1 & 12.2 \\
\hline
\end{tabular}


Table 3. Daily maximum, minimum, and average of hourly average air temperature at the Salix Creek gaging station, 1,587 meters altitude, Salix Creek basin, Washington, water year 2006.

[Abbreviations: Max, maximum; Min, minimum; Avg, average; -, insufficient data]

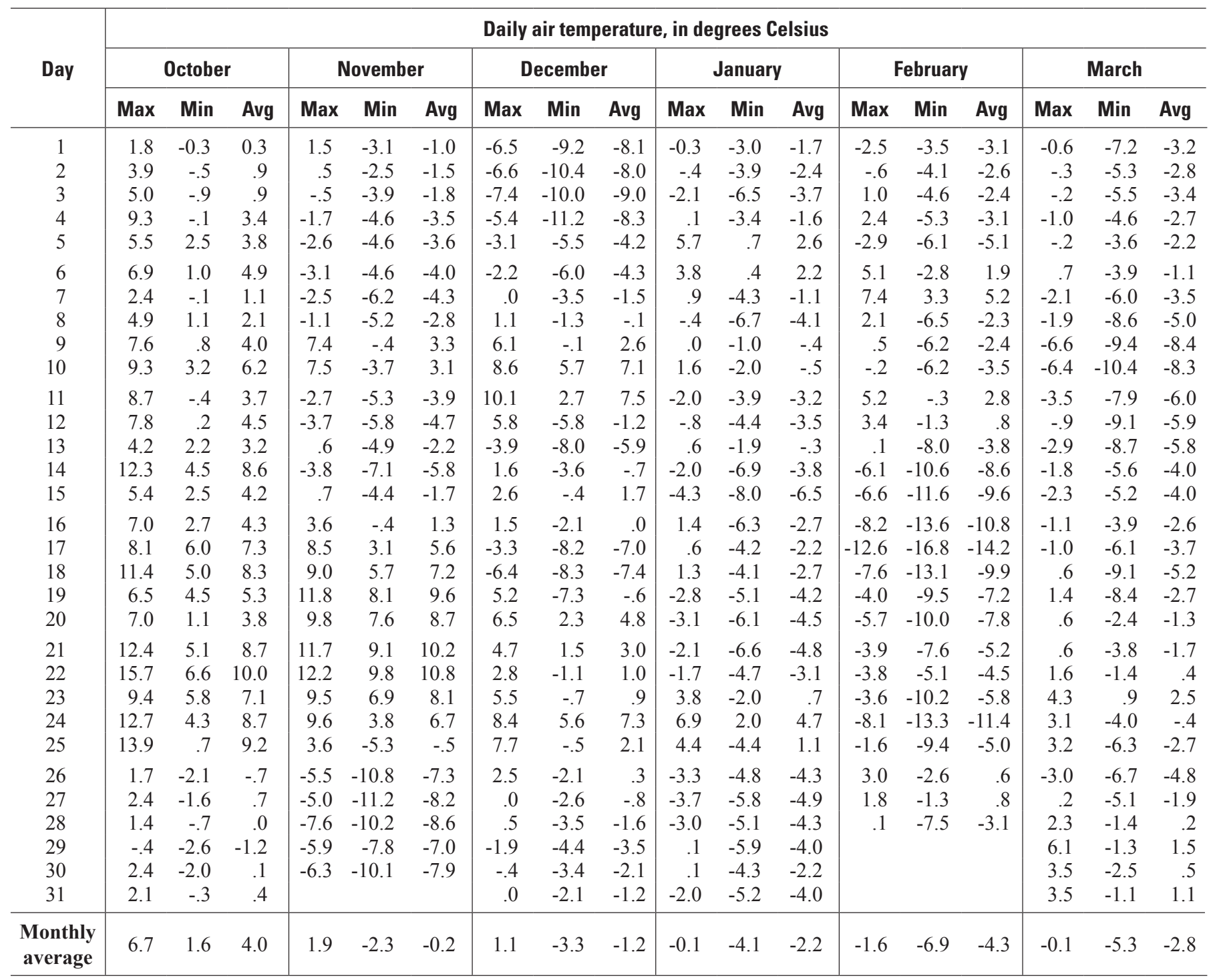


Table 3. Daily maximum, minimum, and average of hourly average air temperature at the Salix Creek gaging station, 1,587 meters altitude, Salix Creek basin, Washington, water year 2006.-Continued

[Abbreviations: Max, maximum; Min, minimum; Avg, average; -, insufficient data]

\begin{tabular}{|c|c|c|c|c|c|c|c|c|c|c|c|c|c|c|c|c|c|c|}
\hline \multirow{3}{*}{ Day } & \multicolumn{18}{|c|}{ Daily air temperature, in degrees Celsius } \\
\hline & \multicolumn{3}{|c|}{ April } & \multicolumn{3}{|c|}{ May } & \multicolumn{3}{|c|}{ June } & \multicolumn{3}{|c|}{ July } & \multicolumn{3}{|c|}{ August } & \multicolumn{3}{|c|}{ September } \\
\hline & Max & Min & Avg & Max & Min & Avg & Max & Min & Avg & Max & Min & Avg & Max & Min & Avg & Max & Min & Avg \\
\hline 1 & 0.8 & -3.3 & -0.9 & -2.0 & -6.1 & -3.5 & - & - & - & - & - & - & 13.8 & 5.3 & 8.5 & 18.0 & 10.1 & 13.8 \\
\hline 2 & .8 & -4.6 & -1.1 & 3.9 & -6.3 & -.4 & - & - & - & - & - & - & 14.9 & 5.9 & 10.2 & 23.0 & 14.0 & 18.3 \\
\hline 3 & 3.2 & -.6 & 1.0 & 8.5 & 1.3 & 4.8 & - & - & - & - & - & - & 18.3 & 7.3 & 12.6 & 25.6 & 16.8 & 20.8 \\
\hline 4 & 4.5 & -4.3 & .8 & 9.8 & 2.8 & 6.6 & - & - & - & - & - & - & 16.1 & 7.3 & 11.4 & 25.5 & 15.0 & 19.9 \\
\hline 5 & 6.0 & .3 & 2.9 & 12.5 & 3.1 & 7.2 & - & - & - & - & - & - & 20.9 & 9.1 & 14.9 & 23.2 & 13.8 & 17.2 \\
\hline 6 & 5.3 & -2.5 & .3 & 2.7 & -2.5 & .1 & - & - & - & - & - & - & 22.8 & 11.6 & 16.4 & 20.8 & 12.4 & 15.9 \\
\hline 7 & 4.9 & -2.8 & 2.2 & 2.5 & -3.6 & -.6 & - & - & - & - & - & - & 23.9 & 12.9 & 17.3 & 20.6 & 10.7 & 15.5 \\
\hline 8 & 4.2 & -1.0 & 2.0 & -.1 & -5.7 & -3.3 & - & - & - & - & - & - & 18.8 & 10.1 & 14.5 & 18.9 & 9.1 & 14.4 \\
\hline 9 & 2.2 & -2.4 & -.1 & 4.3 & -6.6 & -.2 & - & - & - & - & - & - & 13.2 & 9.0 & 10.8 & 8.6 & 5.3 & 6.8 \\
\hline 10 & 4.8 & -2.3 & .4 & 7.0 & 2.5 & 5.4 & - & - & - & - & - & - & 12.7 & 6.5 & 8.4 & 17.2 & 3.7 & 10.7 \\
\hline 11 & 4.3 & -1.9 & 1.2 & 7.5 & -.2 & 3.8 & - & - & - & - & - & - & 10.3 & 5.7 & 7.4 & 20.3 & 11.4 & 14.7 \\
\hline 12 & 1.6 & -3.8 & -.5 & 1.9 & -3.9 & -1.4 & - & - & - & - & - & - & 15.8 & 4.1 & 10.5 & 17.7 & 7.7 & 12.9 \\
\hline 13 & .0 & -4.5 & -2.0 & 6.8 & -3.7 & 2.9 & - & - & - & - & - & - & 20.9 & 9.0 & 14.9 & 7.4 & .6 & 5.2 \\
\hline 14 & -.1 & -6.9 & -3.0 & 12.1 & 5.2 & 9.2 & - & - & - & - & - & - & 21.0 & 10.8 & 15.9 & 3.7 & .0 & 1.2 \\
\hline 15 & -1.6 & -7.0 & -4.8 & 17.1 & 10.6 & 14.0 & - & - & - & - & - & - & 16.4 & 9.4 & 12.3 & 6.7 & .7 & 2.7 \\
\hline 16 & -.3 & -6.8 & -4.4 & 15.9 & 13.4 & 14.5 & - & - & - & - & - & - & 17.6 & 8.1 & 11.7 & 4.0 & .9 & 2.3 \\
\hline 17 & 1.0 & -6.1 & -2.9 & 17.1 & 12.5 & 15.1 & - & - & - & - & - & - & 20.0 & 7.5 & 13.8 & 10.3 & 1.5 & 6.8 \\
\hline 18 & 6.5 & -5.1 & -.1 & 15.1 & 10.0 & 12.5 & - & - & - & - & - & - & 23.1 & 12.6 & 16.8 & 9.4 & 4.1 & 6.9 \\
\hline 19 & 5.8 & .4 & 3.3 & 13.7 & 7.5 & 10.1 & - & - & - & - & - & - & 23.4 & 13.5 & 17 & 5.8 & 3.2 & 4.5 \\
\hline 20 & 7.6 & 2.5 & 5.2 & 10.0 & 4.5 & 6.3 & - & - & - & - & - & - & 25.0 & 13.3 & 18.2 & 4.4 & 2.7 & 3.5 \\
\hline 21 & 2.3 & -5.5 & -1.8 & - & - & - & - & - & - & - & - & - & 26.9 & 12.3 & 19.5 & 4.0 & 1.2 & 2.2 \\
\hline 22 & 6.3 & -6.8 & .8 & - & - & - & - & - & - & - & - & - & 17.3 & 7.5 & 12.5 & 11.0 & 1.2 & 5.7 \\
\hline 23 & 9.0 & 1.7 & 5.6 & - & - & - & - & - & - & - & - & - & 12.3 & 6.5 & 8.7 & 16.6 & 6.5 & 11.3 \\
\hline 24 & 10.1 & 3.9 & 6.4 & - & - & - & - & - & - & - & - & - & 10.7 & 6.1 & 8.3 & 19.6 & 9.6 & 14.2 \\
\hline 25 & 10.7 & 2.4 & 5.5 & - & - & - & - & - & - & - & - & - & 20.3 & 7.7 & 14.1 & 20.5 & 11.5 & 14.5 \\
\hline 26 & 5.0 & -.9 & 1.7 & - & - & - & - & - & - & - & - & - & 22.4 & 11.5 & 16.3 & 20.4 & 11.5 & 14.7 \\
\hline 27 & 6.1 & -.7 & 3.3 & - & - & - & - & - & - & 21.8 & 10.7 & 16.1 & 24.7 & 13.0 & 17 & 21.8 & 12.4 & \\
\hline 28 & 13.1 & 5.3 & 8.9 & - & - & - & - & - & - & 16.5 & 7.4 & 11.9 & 24.7 & 13.1 & 18.8 & 20.7 & 11.3 & 14.3 \\
\hline 29 & 8.4 & -4.6 & 3.4 & - & - & - & - & - & - & 13.3 & 5.4 & 8.3 & 12.0 & 2.1 & 5.3 & 20.4 & 9.9 & 13.9 \\
\hline 30 & 3.6 & -5.5 & -1.1 & - & - & - & - & - & - & 5.7 & 3.1 & 4.3 & 4.3 & 1.2 & 2.8 & 14.3 & 2.8 & 7.9 \\
\hline 31 & & & & & & & & & & 13.0 & 2.1 & 7.6 & 15.0 & 2.1 & 9.0 & & & \\
\hline $\begin{array}{l}\text { Monthly } \\
\text { average }\end{array}$ & 4.5 & -2.4 & 1.1 & - & - & - & - & - & - & - & - & - & 18.0 & 8.5 & 12.8 & 15.3 & 7.4 & 11.0 \\
\hline
\end{tabular}



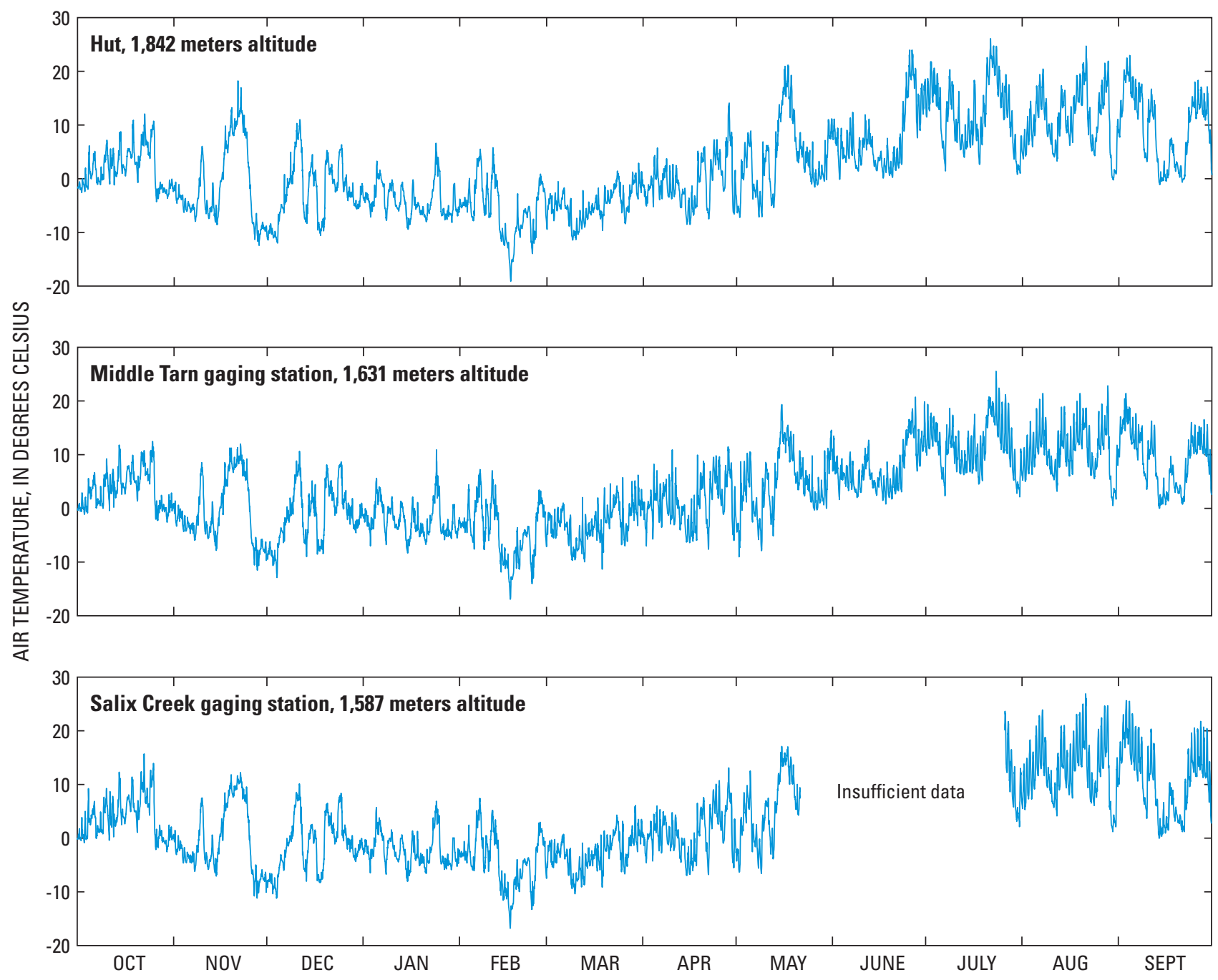

Figure 3. Hourly average air temperature at selected sites in and near South Cascade Lake basin, Washington, water year 2006. Daily summaries are presented in tables 1-3. 


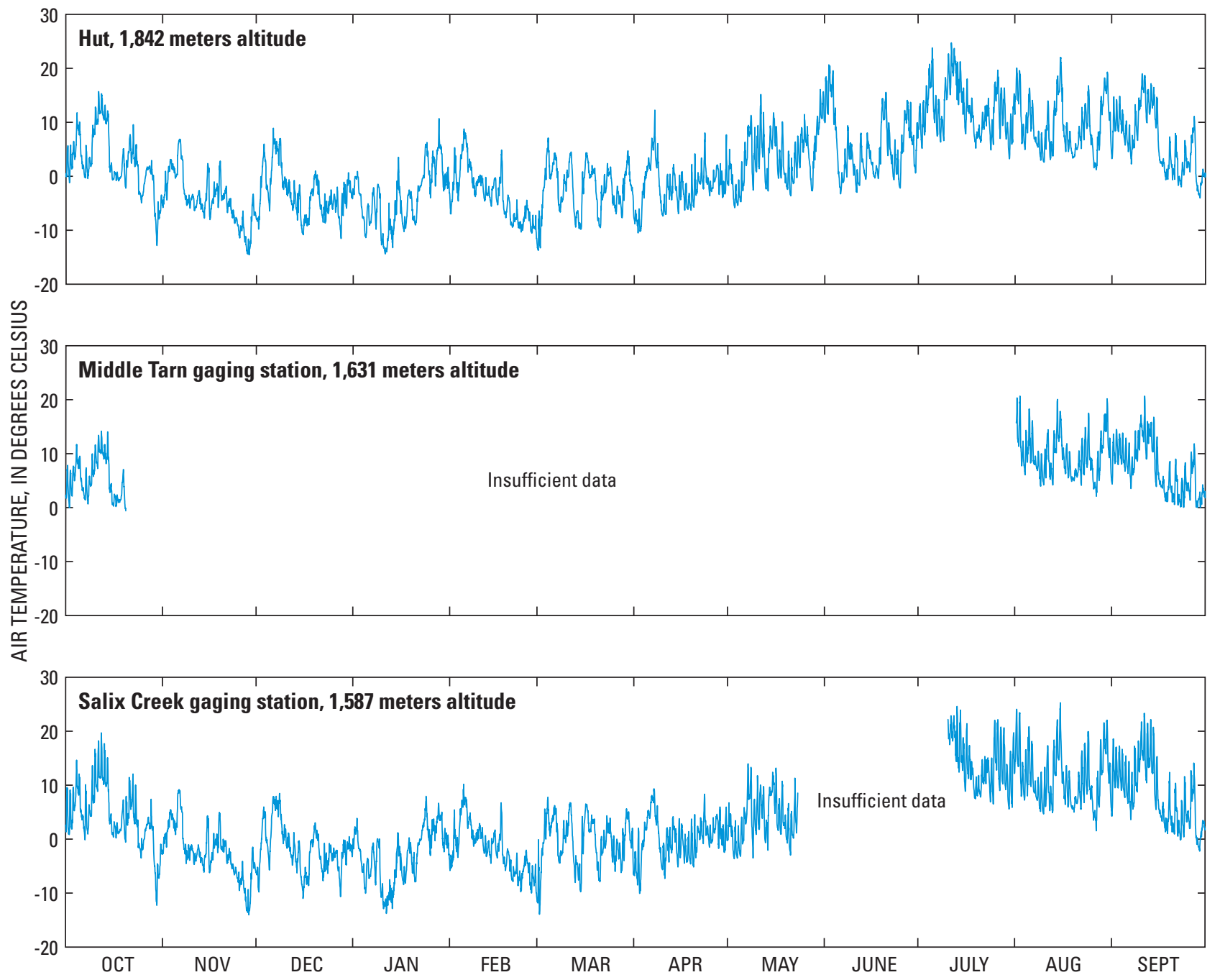

Figure 4. Hourly average air temperature at selected sites in and near South Cascade Lake basin, Washington, water year 2007. Daily summaries are presented in tables 4-6. 
Table 4. Daily maximum, minimum, and average of hourly average air temperature at the Hut, 1,842 meters altitude, near South Cascade Lake basin, Washington, water year 2007.

[Abbreviations: Max, maximum; Min, minimum; Avg, average; -, insufficient data]

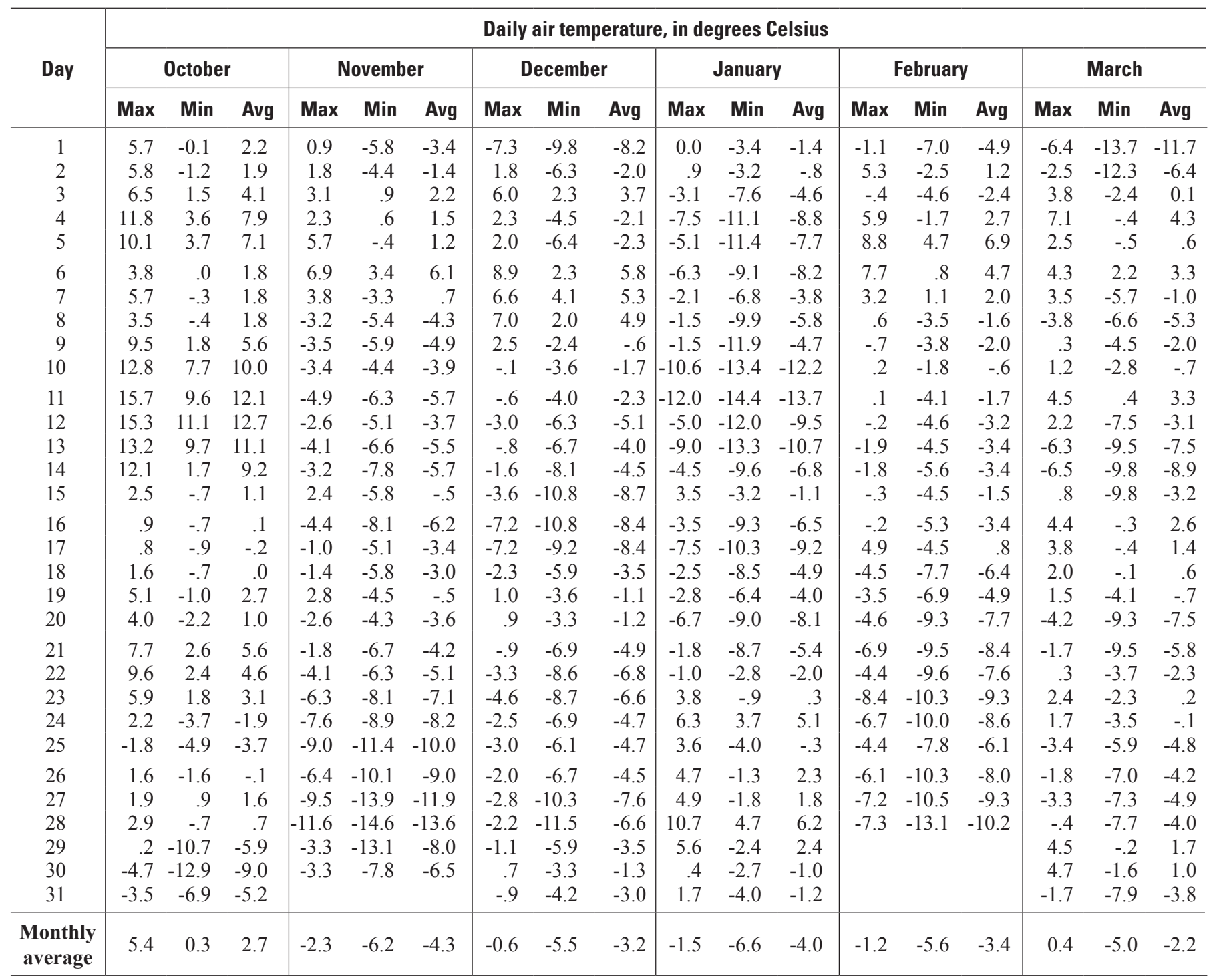


Table 4. Daily maximum, minimum, and average of hourly average air temperature at the Hut, 1,842 meters altitude, near South Cascade Lake basin, Washington, water year 2007.-Continued

[Abbreviations: Max, maximum; Min, minimum; Avg, average; -, insufficient data]

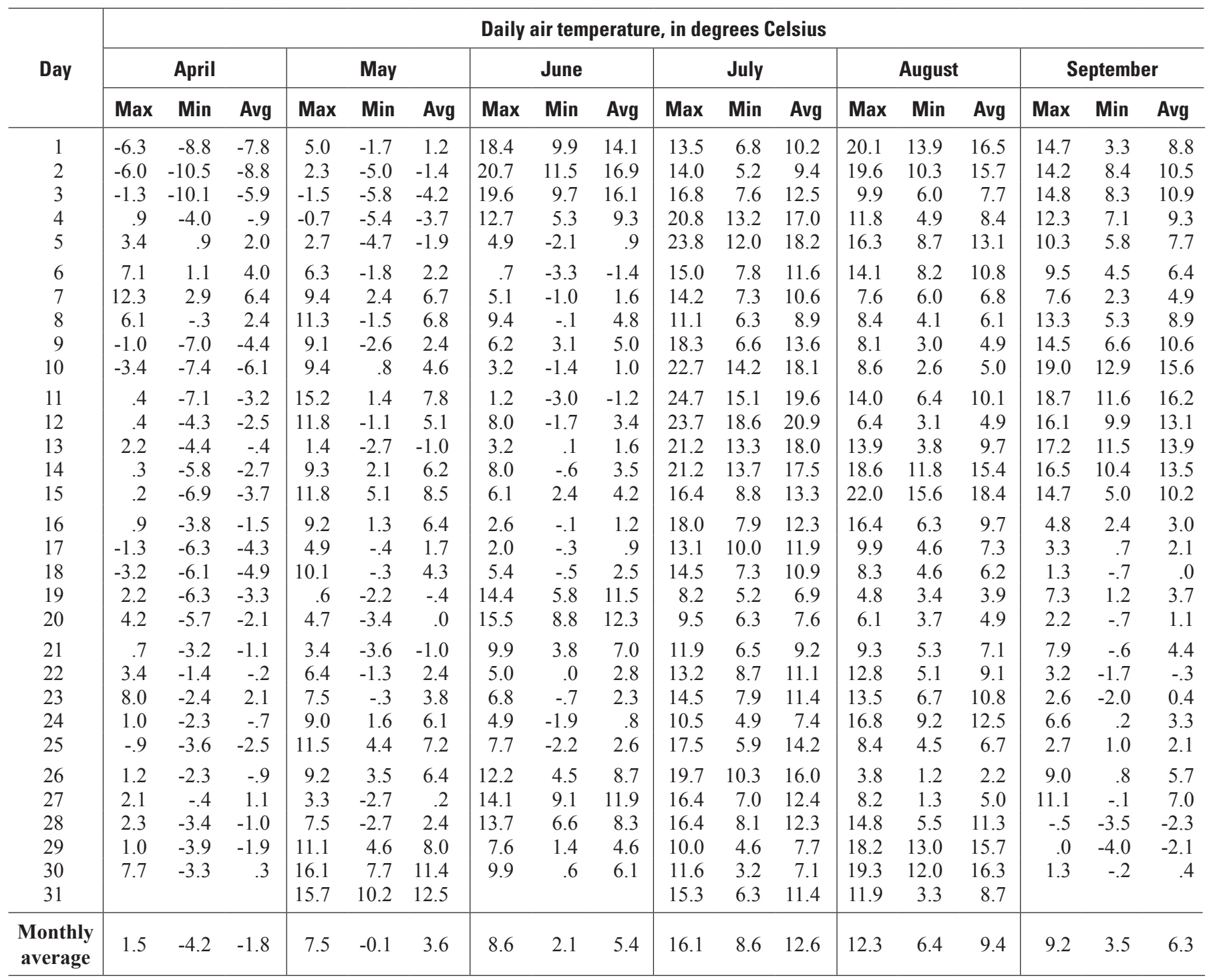


Table 5. Daily maximum, minimum, and average of hourly average air temperature at the Middle Tarn gaging station, 1,631 meters altitude, Middle Tarn basin, Washington, water year 2007.

[Abbreviations: Max, maximum; Min, minimum; Avg, average; -, insufficient data]

\begin{tabular}{|c|c|c|c|c|c|c|c|c|c|}
\hline \multirow{4}{*}{ Day } & \multicolumn{9}{|c|}{ Daily air temperature, in degrees Celsius } \\
\hline & \multirow{2}{*}{\multicolumn{3}{|c|}{$\begin{array}{c}2006 \\
\text { October }\end{array}$}} & \multicolumn{6}{|c|}{2007} \\
\hline & & & & \multicolumn{3}{|c|}{ August } & \multicolumn{3}{|c|}{ September } \\
\hline & Max & Min & Avg & Max & Min & Avg & Max & Min & Avg \\
\hline 1 & 7.8 & 1.7 & 3.9 & - & - & - & 13.6 & 4.4 & 9.1 \\
\hline 2 & 6.9 & .0 & 3.2 & 20.7 & 11.1 & 14.8 & 14.5 & 8.2 & 11.0 \\
\hline 3 & 7.7 & 2.1 & 5.4 & 12.3 & 7.7 & 9.5 & 13.7 & 8.0 & 10.7 \\
\hline 4 & 11.7 & 5.8 & 8.7 & 14.3 & 6.1 & 9.6 & 13.8 & 8.0 & 10.1 \\
\hline 5 & 9.5 & 4.8 & 7.5 & 18.3 & 8.4 & 13.1 & 12.9 & 6.7 & 9.3 \\
\hline 6 & 5.5 & 2.1 & 3.5 & $\mid 16.1$ & 8.3 & 11.3 & 12.0 & 5.7 & 8.4 \\
\hline 7 & 7.4 & 1.4 & 3.6 & 9.6 & 7.3 & 8.2 & 9.4 & 3.5 & 6.4 \\
\hline 8 & 5.8 & .7 & 3.3 & 10.5 & 5.6 & 7.9 & 14.2 & 6.4 & 9.7 \\
\hline 9 & 10.0 & 3.9 & 6.1 & 10.0 & 4.0 & 6.6 & 14.3 & 8.6 & 11.0 \\
\hline 10 & 11.6 & 6.2 & 8.7 & 10.9 & 4.2 & 6.7 & 17.2 & 13.3 & 15.1 \\
\hline 11 & 13.4 & 7.2 & 10.2 & 14.4 & 6.2 & 11.2 & 20.7 & 10.4 & 14.8 \\
\hline 12 & 14.2 & 9.9 & 11.1 & 8.4 & 5.2 & 6.7 & 16.0 & 9.0 & 12.7 \\
\hline 13 & 11.7 & 8.1 & 9.8 & 14.3 & 4.2 & 9.4 & 15.8 & 10.8 & 13.7 \\
\hline 14 & 14.0 & 3.9 & 9.6 & 20.1 & 10.2 & 14.1 & 16.8 & 6.4 & 11.6 \\
\hline 15 & 4.5 & .6 & 3.0 & 17.8 & 12.2 & 15.0 & 13.1 & 3.9 & 8.0 \\
\hline 16 & 2.5 & .3 & 1.4 & 12.4 & 7.3 & 9.7 & 6.5 & 3.9 & 4.7 \\
\hline 17 & 2.4 & .2 & 1.4 & 11.9 & 6.3 & 8.8 & 5.8 & 2.6 & 4.1 \\
\hline 18 & 2.8 & 1.0 & 1.6 & 10.4 & 5.5 & 7.5 & 2.8 & 1.1 & 1.8 \\
\hline 19 & 7.1 & .8 & 4.4 & \begin{tabular}{|l|}
5.7 \\
\end{tabular} & 4.9 & 5.3 & 8.6 & 3.3 & 5.2 \\
\hline 20 & - & - & - & 7.2 & 5.0 & 6.2 & 4.0 & 1.0 & 2.6 \\
\hline 21 & - & - & - & 10.5 & 5.8 & 7.8 & 9.0 & .6 & 5.0 \\
\hline 22 & - & - & - & 12.9 & 4.1 & 8.7 & 5.3 & .5 & 1.6 \\
\hline 23 & - & - & - & 14.9 & 6.1 & 10.1 & 5.4 & .2 & 2.7 \\
\hline 24 & - & - & - & 17.5 & 7.4 & 11.6 & 8.3 & .1 & 4.5 \\
\hline 25 & - & - & - & \begin{tabular}{|l|}
9.3 \\
\end{tabular} & 6.1 & 8.1 & 4.6 & 2.5 & 3.7 \\
\hline 26 & - & - & - & 5.3 & 3.3 & 4.1 & 10.3 & 1.4 & 6.1 \\
\hline 27 & - & - & - & 10.5 & 2.1 & 6.1 & 11.8 & 1.2 & 7.8 \\
\hline 28 & - & - & - & 14.2 & 5.3 & 9.8 & 1.6 & .0 & .8 \\
\hline 29 & - & - & - & 17.3 & 11.0 & 13.9 & 2.9 & .0 & 1.5 \\
\hline 30 & - & - & - & 20.2 & 10.9 & 16.1 & 4.2 & 1.8 & 3.0 \\
\hline 31 & - & - & - & 12.9 & 5.1 & 9.3 & & & \\
\hline $\begin{array}{c}\text { Monthly } \\
\text { average }\end{array}$ & - & - & - & - & - & - & 10.3 & 4.5 & 7.2 \\
\hline
\end{tabular}



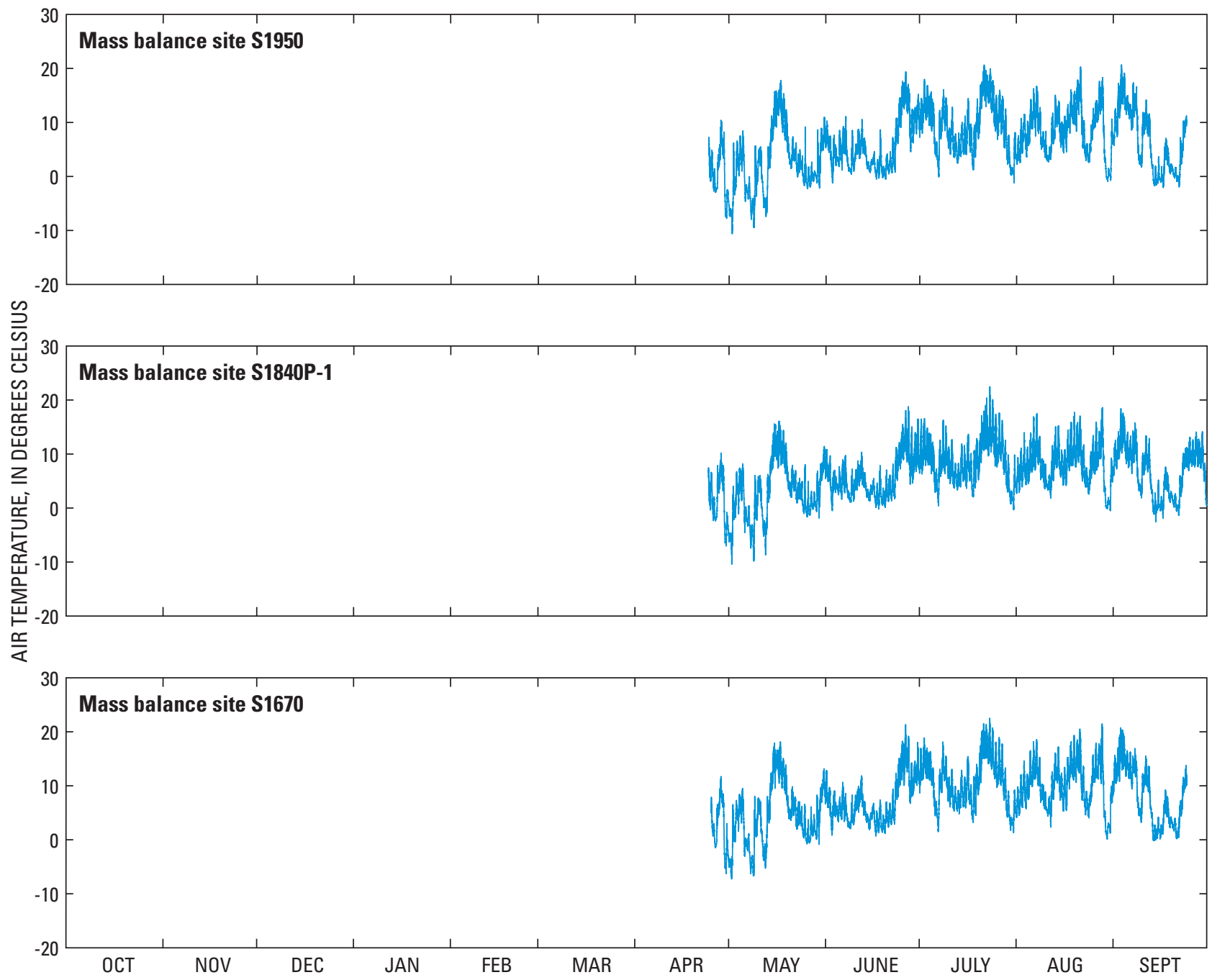

Figure 5. Air temperature at a height of 2 meters recorded at 10-minute intervals at three mass balance sites on South Cascade Glacier, Washington, April-September 2006. Daily summaries are presented in tables 7-9. Locations of mass balance sites are shown in figure 2 . 
Table 6. Daily maximum, minimum, and average of hourly average air temperature at the Salix Creek gaging station, 1,587 meters altitude, Salix Creek basin, Washington, water year 2007.

[Abbreviations: Max, maximum; Min, minimum; Avg, average; -, insufficient data]

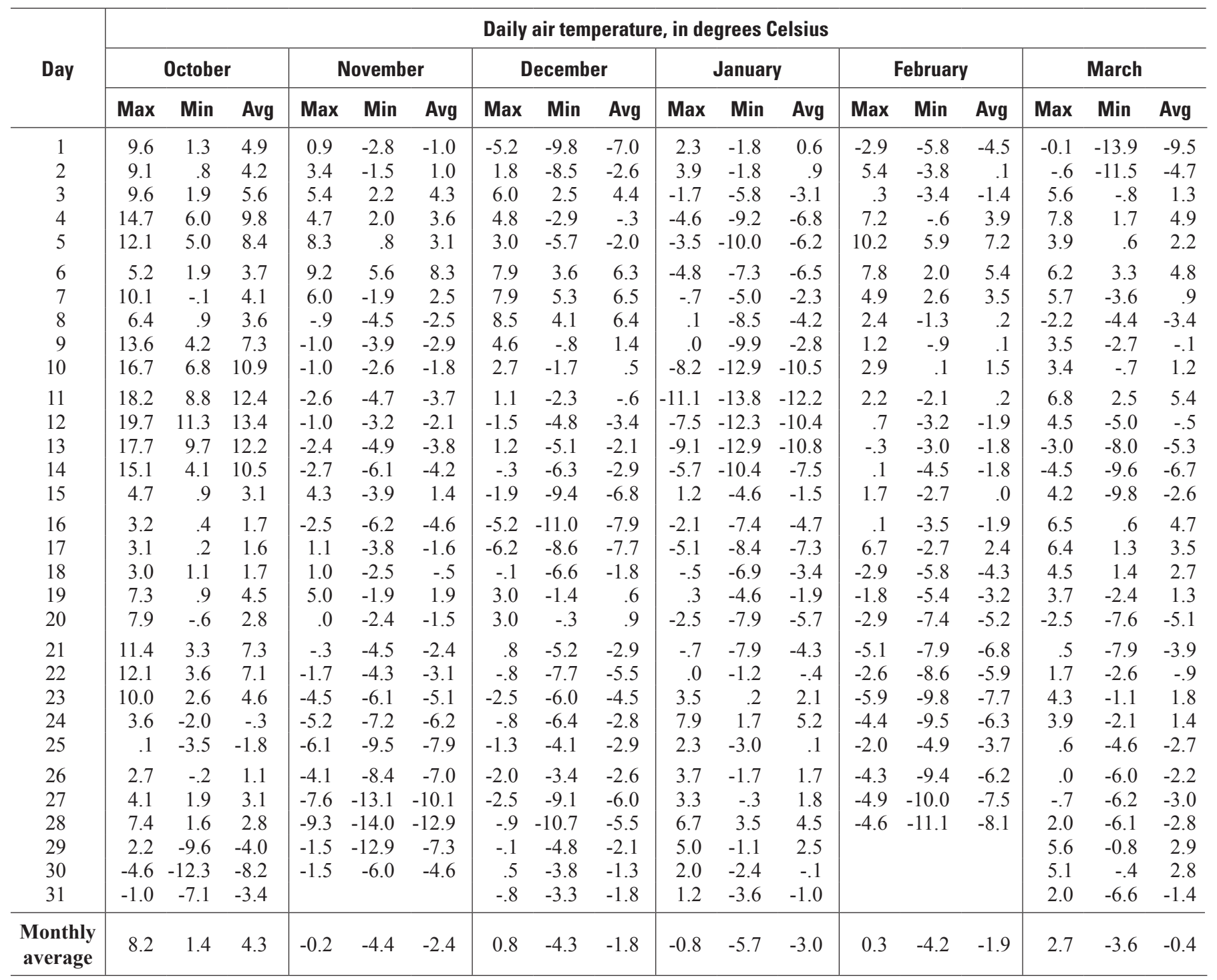


Table 6. Daily maximum, minimum, and average of hourly average air temperature at the Salix Creek gaging station, 1,587 meters altitude, Salix Creek basin, Washington, water year 2007.-Continued

[Abbreviations: Max, maximum; Min, minimum; Avg, average; -, insufficient data]

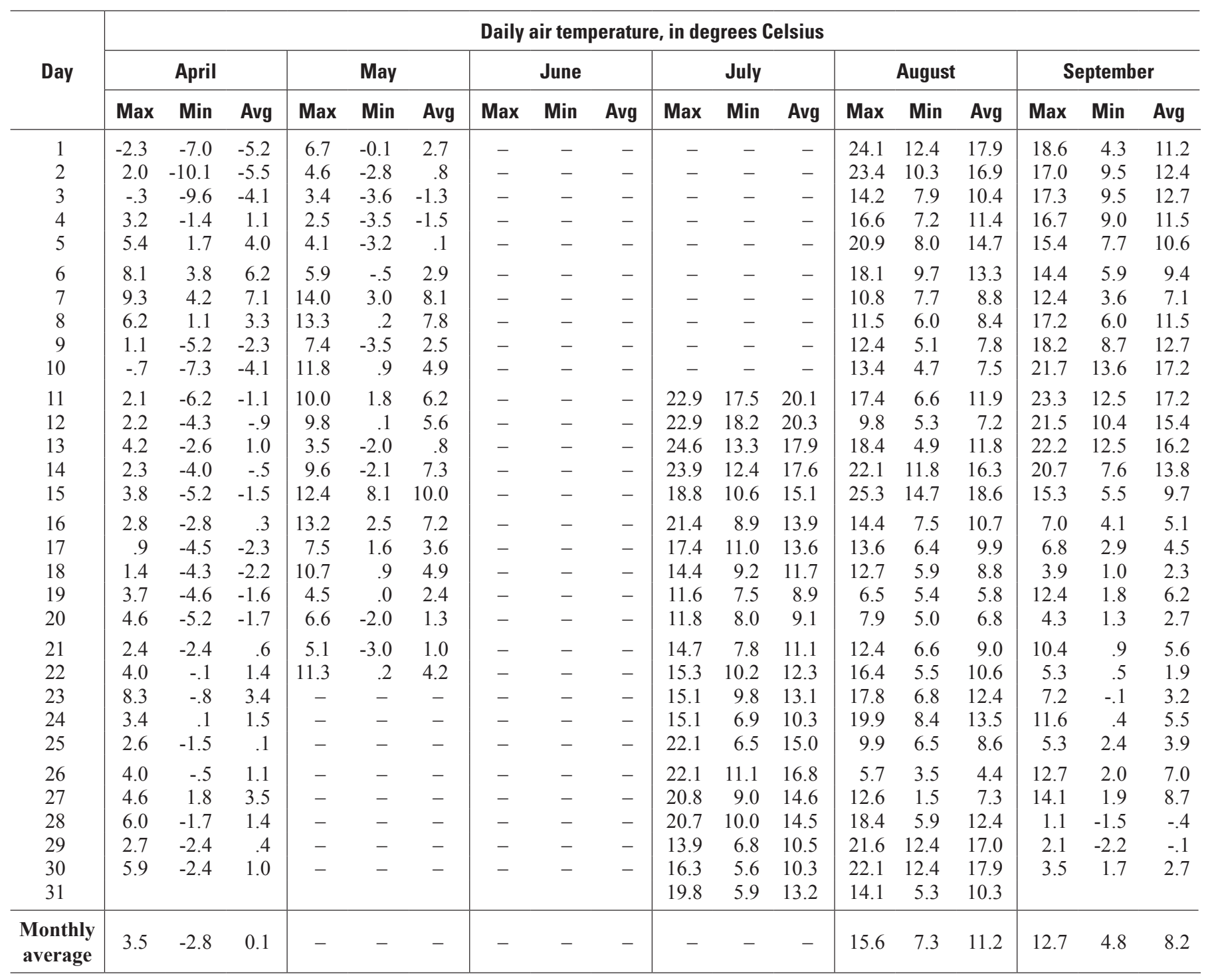


Table 7. Daily maximum, minimum, and average 2-meter-height air temperature at mass balance site S1950 on South Cascade Glacier, Washington, 1,945 meters altitude, April-September 2006.

[Abbreviations: Max, maximum; Min, minimum; Avg, average; -, insufficient data]

\begin{tabular}{|c|c|c|c|c|c|c|c|c|c|c|c|c|c|c|c|c|c|c|}
\hline \multirow{3}{*}{ Day } & \multicolumn{18}{|c|}{ Daily air temperature, in degrees Celsius } \\
\hline & \multicolumn{3}{|c|}{ April } & \multicolumn{3}{|c|}{ May } & \multicolumn{3}{|c|}{ June } & \multicolumn{3}{|c|}{ July } & \multicolumn{3}{|c|}{ August } & \multicolumn{3}{|c|}{ September } \\
\hline & Max & Min & Avg & Max & Min & Avg & Max & Min & Avg & Max & Min & Avg & Max & Min & Avg & Max & Min & Avg \\
\hline 1 & - & - & - & -5.3 & -8.1 & -6.6 & 10.3 & 4.9 & 7.6 & 14.4 & 7.3 & 10.8 & 7.6 & 2.3 & 4.2 & 12.5 & 5.8 & 9.2 \\
\hline 2 & - & - & - & 6.2 & -10.6 & -3.0 & 7.5 & .5 & 4.7 & 18.0 & 9.7 & 13.3 & 10.8 & 2.6 & 5.8 & 17.2 & 7.4 & 11.7 \\
\hline 3 & - & - & - & 6.6 & -2.5 & 1.7 & 7.7 & -1.2 & 2.9 & 16.8 & 10.4 & 13.3 & 11.5 & 5. & 8.6 & 20.7 & 12.0 & 16.3 \\
\hline 4 & - & - & - & 7.5 & .1 & 3.9 & 5.9 & 2.0 & 3.4 & 15.7 & 8.4 & 12.0 & 10.2 & 3.6 & 6.5 & 19.1 & 12.3 & 15.9 \\
\hline 5 & - & - & - & 8.5 & .1 & 4.1 & 8.6 & 1.8 & 4.1 & 14.4 & 5.4 & 10.1 & 14.3 & 6.1 & 10.2 & 15.0 & 11.5 & 13.3 \\
\hline 6 & - & - & - & -.1 & -4.6 & -2.6 & 9.3 & 1.2 & 5.6 & 6.5 & 1.6 & 4.0 & 16.3 & 8.9 & 11.7 & 13.4 & 8.6 & 11.3 \\
\hline 7 & - & - & - & .0 & -5.9 & -3.0 & 11.1 & 2.5 & 6. & 12.3 & -.1 & 6.9 & 16.7 & 5 & 12. & 17.3 & 8.8 & 12.6 \\
\hline 8 & - & - & - & -4.1 & -8.5 & -6.2 & 2.8 & .9 & 1. & 16.0 & 8.3 & 11.7 & 12.8 & & 9 & 16 & 4.4 & 11.3 \\
\hline 9 & - & - & - & 5.7 & -9.5 & -1.6 & 8.6 & .4 & 2. & 14.5 & 7.2 & 10.9 & 8.3 & 5. & 6.6 & 5.3 & 1.8 & 3.1 \\
\hline 10 & - & - & - & 5.1 & -1.4 & 2.4 & 6.0 & .9 & 3.8 & 9.0 & 4.1 & 6.7 & 8.4 & 2.9 & 4.6 & 11.9 & 1.7 & 7.4 \\
\hline 11 & - & - & - & 5.5 & -3.2 & 1.2 & 8.8 & 3.3 & 5.8 & 12.9 & 3.8 & 7.9 & 5.5 & 2.7 & 3.6 & 14.2 & 8.0 & 10.4 \\
\hline 12 & - & - & - & -3.3 & -7.4 & -5.1 & 10.6 & 4.1 & 6. & 7. & 3.1 & 5.1 & 11. & & 7 & 11.6 & 4.7 & 8.6 \\
\hline 13 & - & - & - & 5.5 & -6.7 & .0 & 7.1 & 3.6 & 5. & 8.1 & 2.4 & 4.5 & 15.0 & 6.9 & 10 & 5.0 & -1.4 & 1.7 \\
\hline 14 & - & - & - & 11.2 & 1.6 & 6.7 & 3.6 & 1.0 & 2. & 10.0 & 3.7 & 6.8 & 14.0 & 7.2 & 11 & 2.0 & -1.7 & -.8 \\
\hline 15 & - & - & - & 15.7 & 6.9 & 11.4 & 3.1 & .8 & 1.9 & 11.2 & 4.0 & 6.3 & 10.1 & 5.4 & 7.3 & 3.7 & -1.3 & .0 \\
\hline 16 & - & - & - & 15.9 & 9.1 & 13.1 & 4.6 & .5 & 2.5 & 14.4 & 4.6 & 9.8 & 11.2 & 4.4 & 7.8 & 1.8 & -2.0 & -.5 \\
\hline 17 & - & - & - & 17.8 & 10.4 & 14.7 & 3. & -.5 & .9 & 9.7 & 2.1 & 5. & 13.3 & 4.6 & 10. & 7.1 & -1.8 & 3.4 \\
\hline 18 & - & - & - & 15.4 & 6.8 & 11.4 & 8. & -.3 & 3.0 & 9.5 & 1.2 & 4.9 & 16 & 8.0 & 12 & 6.8 & .8 & 3.5 \\
\hline 19 & - & - & - & 12.4 & 4.5 & 8.1 & 1.9 & -.2 & .6 & 14.4 & 7.0 & 9.6 & 15.8 & 9.5 & 12 & 2.4 & .5 & 1.5 \\
\hline 20 & - & - & - & 7.3 & 1.5 & 3.3 & 4.2 & -.5 & 1.8 & 17.0 & 8.0 & 13.3 & 17.9 & 8.4 & 13.9 & 1.7 & -.3 & .7 \\
\hline 21 & - & - & - & 7.3 & 1.6 & 4.5 & 4.6 & .5 & 2.0 & 20.6 & 14.1 & 17.3 & 20.3 & 7.8 & 15.5 & 1.6 & -1.3 & -.2 \\
\hline 22 & - & - & - & 6.2 & -.1 & 2. & 7.2 & .7 & 3. & 19.7 & 13.0 & 16. & 11.1 & & & & -2.0 & 2.5 \\
\hline 23 & - & - & - & 4.9 & -.1 & 2.7 & 10.8 & .8 & 6.3 & 20.0 & 12.5 & 15.8 & 6.1 & 2.9 & 4.4 & 10.3 & 3.6 & 7.4 \\
\hline 24 & - & - & - & 3.8 & -1.3 & 1.2 & 14.6 & 6.1 & 10.8 & 17.8 & 9.3 & 14.2 & 9.5 & & & - & - & - \\
\hline 25 & 4.9 & -0.9 & 1.7 & 9.2 & -1.8 & .1 & 17.6 & 10.8 & 14.6 & 15.0 & 6.9 & 11.2 & 12.7 & 6.7 & 9.4 & - & - & - \\
\hline 26 & 1.4 & -2.9 & -1.5 & 1.8 & -2.3 & -.9 & 19.4 & 12.2 & 15.5 & 16.0 & 7.6 & 11.5 & 14.1 & 9.1 & 11.6 & - & - & - \\
\hline 27 & 5.3 & -2.4 & 1.0 & 2.7 & -1.9 & -.3 & 17.1 & 7.1 & 13.2 & 14.9 & 6.6 & 10.7 & 17.6 & 10.4 & 13.4 & - & - & - \\
\hline 28 & 10.4 & 2.9 & 6.8 & 1.1 & -.9 & .1 & 12.5 & 4.6 & 8.6 & 12.5 & 3.7 & 7.4 & 18.3 & 7.5 & 14.1 & - & - & - \\
\hline 29 & 8.2 & -7.4 & 1.3 & 8.7 & -2.1 & 1.1 & 12.8 & 6.2 & 10.4 & 7.7 & 1.8 & 3.9 & 8.5 & -.4 & 2.4 & - & - & - \\
\hline 30 & -2.5 & -7.8 & -4.9 & & & & 15.2 & 8.5 & 11.6 & & .2 & 1.0 & 1.5 & -.9 & .1 & - & - & - \\
\hline 31 & & & & 11.0 & 4.9 & 7.9 & & & & 8.2 & -1.2 & 3.8 & 10.6 & -.7 & 5.0 & & & \\
\hline $\begin{array}{l}\text { Monthly } \\
\text { average }\end{array}$ & - & - & - & 6.4 & -1.0 & 2.5 & 8.8 & 2.8 & 5.6 & 13.1 & 5.7 & 9.3 & 12.2 & 5.1 & 8.6 & - & - & - \\
\hline
\end{tabular}


Table 8. Daily maximum, minimum, and average 2-meter-height air temperature at mass balance site S1840P-1 on South Cascade Glacier, Washington, 1,837 meters altitude, April-September 2006.

[Abbreviations: Max, maximum; Min, minimum; Avg, average; -, insufficient data]

\begin{tabular}{|c|c|c|c|c|c|c|c|c|c|c|c|c|c|c|c|c|c|c|}
\hline \multirow{3}{*}{ Day } & \multicolumn{18}{|c|}{ Daily air temperature, in degrees Celsius } \\
\hline & \multicolumn{3}{|c|}{ April } & \multicolumn{3}{|c|}{ May } & \multicolumn{3}{|c|}{ June } & \multicolumn{3}{|c|}{ July } & \multicolumn{3}{|c|}{ August } & \multicolumn{3}{|c|}{ September } \\
\hline & Max & Min & Avg & Max & Min & Avg & Max & Min & Avg & Max & Min & Avg & Max & Min & Avg & Max & Min & Avg \\
\hline 1 & - & - & - & -4.2 & -7.6 & -5.7 & 10.8 & 4.9 & 7.6 & 16.5 & 6.3 & 10.2 & 9.3 & 2.7 & 5.2 & 12.5 & 6.1 & 8.9 \\
\hline 2 & - & - & - & 4.0 & -10.4 & -2.4 & 9.7 & 1.2 & 5.5 & 16.6 & 7.0 & 10.6 & 11.1 & 2.9 & 6 & & 7.3 & 10.3 \\
\hline 3 & - & - & - & 6.7 & -1.8 & 2. & 7.0 & -.5 & 3.5 & 14.8 & 7.9 & 10.7 & 14.0 & 4. & 2 & 18.4 & 9.3 & 13.1 \\
\hline 4 & - & - & - & 7.4 & -1.1 & 4.4 & 7.0 & 2.9 & 4.3 & 13.9 & 6.4 & 10.5 & 11.3 & 4.3 & 7.3 & 17.6 & 10.5 & 13.5 \\
\hline 5 & - & - & - & 8.2 & .8 & 4.5 & 7.7 & 2.4 & 4.4 & 12.2 & 4.5 & 8.6 & 13.9 & 5.0 & 9.2 & 14.1 & 7.5 & 10.9 \\
\hline 6 & - & - & - & .9 & -4.5 & -1.7 & 9.0 & 1.6 & 5.4 & 7.3 & 2.2 & 4.1 & 16.9 & 6.6 & 10.4 & 13.4 & 7.8 & 10.2 \\
\hline 7 & - & - & - & .5 & -5.3 & -2.3 & 9. & 2.8 & 5. & 12.6 & .4 & 6.2 & 17.5 & 7.0 & 11 & 14 & 6.4 & 10.6 \\
\hline 8 & - & - & - & -3.1 & -8.1 & -5.4 & 3.5 & & 2.2 & & 6.3 & & 13.3 & & & & 4.8 & 10.5 \\
\hline 9 & - & - & - & 6.0 & -9.8 & -1.2 & 7.2 & 1.1 & 3.0 & 15.2 & 6.4 & 9. & 9.1 & 4. & & 5.5 & 2.4 & 3.9 \\
\hline 10 & - & - & - & 5.9 & -2.3 & 3.0 & 7.1 & 1.2 & 4.0 & 11.3 & 4.5 & 7.7 & 8.2 & 3.6 & 5.0 & 10.2 & 1.9 & 6.3 \\
\hline 11 & - & - & - & 6.0 & -2.4 & 1.8 & 8.7 & 3.3 & 5.5 & 12.7 & 4.4 & 7.8 & 6.1 & 2.9 & 4.4 & 13.4 & 7.0 & 9.6 \\
\hline 12 & - & - & - & -2.4 & -8.7 & -4.3 & 10.3 & & 7. & 8. & 3.7 & & 11.6 & & & 12.9 & & 8.8 \\
\hline 13 & - & - & - & 6.2 & -4.9 & .7 & 6.6 & 3.7 & 5. & 8.3 & 3.4 & 5 & 15.0 & 5.9 & 9.8 & 6.1 & -.8 & 2.7 \\
\hline 14 & - & - & - & 9.9 & 1.8 & 6.7 & 4. & 1.4 & 2. & 11.9 & 3.9 & 7 & 15.2 & 7.3 & 10.8 & 2.8 & -2.6 & -.2 \\
\hline 15 & - & - & - & 15.6 & 7.4 & 10.9 & 4.3 & 1.3 & 2.7 & 11.6 & 4.1 & 7.0 & 10.8 & 5.4 & 7.7 & 5.2 & -.4 & .8 \\
\hline 16 & - & - & _- & 15.5 & 7.4 & 11.5 & 5.5 & 1.3 & 3.5 & 13.7 & 3.7 & 8.6 & 10.8 & 4.2 & 7.0 & 2.2 & -1.3 & .2 \\
\hline 17 & - & - & - & 16.1 & 7.7 & 12.4 & 4.7 & .2 & 1. & 10 & 3.1 & 6.7 & 14.4 & 4.2 & & 7.6 & -1.9 & 3.9 \\
\hline 18 & - & - & - & 14.4 & 7.5 & 10.5 & 7.9 & -.2 & 3. & 10. & 2.1 & 5.3 & & 7.0 & 10.8 & 7.3 & 1.7 & 4.3 \\
\hline 19 & - & - & - & 12.1 & 5.0 & 8.1 & 3.7 & .5 & 1.4 & 12.9 & 4.7 & 8.4 & 17.7 & 7.7 & 11.3 & 3.1 & 1.0 & 2.2 \\
\hline 20 & - & - & - & 6.7 & 2.0 & 4.0 & 7.1 & .1 & 3.0 & 17.1 & 6.3 & 10.6 & 15.8 & 7.6 & 11.1 & 2.7 & .2 & 1.4 \\
\hline 21 & - & - & - & 7.9 & 2.0 & 4.9 & 6.1 & 1.2 & 3.3 & 18.0 & 10.7 & 13.9 & 17.0 & 7.3 & 12.2 & 2.6 & -.6 & .3 \\
\hline 22 & - & - & - & 7.0 & .9 & 3. & 8.1 & & 4. & 20.4 & 10.8 & & 11.7 & & 8.1 & & -1.3 & 2.7 \\
\hline 23 & - & - & - & 5.5 & 1.0 & 3.3 & 11.2 & 1.8 & 6.0 & 22.5 & 9.7 & 14.9 & 7.5 & 3.9 & 5.3 & 10.1 & 3.5 & 7.4 \\
\hline 24 & - & - & - & 4.9 & -.6 & 1.9 & 12.2 & 5.1 & 9.0 & 20.1 & 10.4 & & 10.5 & 2.6 & 5.0 & & 7.6 & 9.3 \\
\hline 25 & 6.6 & -0.4 & 2.8 & 8.0 & -1.1 & .8 & 15.5 & 7.3 & 11.0 & 17.4 & 7.6 & 12.2 & 13.4 & 5.5 & 8.6 & 13.1 & 6.9 & 9.9 \\
\hline 26 & 2.1 & -2.3 & -.7 & 5.0 & -1.6 & -.2 & 18.1 & 9.1 & 12.1 & 17.6 & 8.3 & 11.7 & 15.9 & 6.3 & 10.1 & 12.6 & 7.7 & 10.0 \\
\hline 27 & 7.9 & -2.0 & 1.9 & 3.1 & -1.3 & .3 & 18.8 & 7.8 & 12.1 & 16.3 & 7.3 & 11.5 & 14.3 & 7.7 & 10.5 & 14.1 & 7.6 & 10.6 \\
\hline 28 & 10.2 & 3.3 & 6.7 & 3.0 & -.2 & .9 & 15.0 & 4.4 & 8.6 & 12. & 4.2 & 8.0 & 18.6 & 7.9 & 12.8 & & 7.7 & 10.1 \\
\hline 29 & 7.9 & -6.4 & 1.8 & 6.8 & -1.7 & 1.6 & 14.0 & 5.2 & 8.9 & 9.8 & 2.5 & 4.8 & 10.0 & .0 & 3.0 & 14.1 & 7.4 & 10.2 \\
\hline 30 & -.8 & -7.0 & -4.1 & & -1.9 & 5.1 & 16.5 & 6.8 & 10.6 & 3.2 & .8 & 1.8 & 2.0 & -.1 & 0.7 & 8.3 & .5 & 4.9 \\
\hline 31 & & & & 11.4 & 6.2 & 8.6 & & & & 9.9 & -.3 & 4.0 & 9.3 & -.5 & 4.9 & & & \\
\hline $\begin{array}{l}\text { Monthly } \\
\text { average }\end{array}$ & - & - & - & 6.6 & -0.8 & 2.9 & 9.2 & 2.8 & 5.6 & 13.6 & 5.3 & 8.8 & 12.5 & 4.7 & 8.1 & 10.1 & 4.0 & 6.9 \\
\hline
\end{tabular}


Table 9. Daily maximum, minimum, and average 2-meter-height air temperature at mass balance site S1670 on South Cascade Glacier, Washington, 1,674 meters altitude, April-September 2006.

[Abbreviations: Max, maximum; Min, minimum; Avg, average; -, insufficient data]

\begin{tabular}{|c|c|c|c|c|c|c|c|c|c|c|c|c|c|c|c|c|c|c|}
\hline \multirow{3}{*}{ Day } & \multicolumn{18}{|c|}{ Daily air temperature, in degrees Celsius } \\
\hline & \multicolumn{3}{|c|}{ April } & \multicolumn{3}{|c|}{ May } & \multicolumn{3}{|c|}{ June } & \multicolumn{3}{|c|}{ July } & \multicolumn{3}{|c|}{ August } & \multicolumn{3}{|c|}{ September } \\
\hline & Max & Min & Avg & Max & Min & Avg & Max & Min & Avg & Max & Min & Avg & Max & Min & Avg & Max & Min & Avg \\
\hline 1 & - & - & - & -3.2 & -6.7 & -4.5 & 12.8 & 6.0 & 9.2 & 17.0 & 8.7 & 12.5 & 9.8 & 4.2 & 6.6 & 15.6 & 8.3 & 12.0 \\
\hline 2 & - & - & - & 6.5 & -7.2 & -.7 & 9.7 & 2.7 & 6.7 & 18.9 & 11.1 & 14.1 & 12.1 & 4.5 & 7.9 & 17.1 & 10.5 & 13.4 \\
\hline 3 & - & - & - & 7.3 & -.4 & 3.9 & 9.0 & .9 & 4.7 & 17.0 & 11.3 & 14.2 & 14.6 & 6.0 & 9.7 & 20.7 & 10.8 & 17.0 \\
\hline 4 & - & - & - & 8.4 & 1.6 & 5.9 & 9.0 & 4.3 & 5.7 & 16.4 & 10.9 & 13.9 & 12.1 & 5.8 & 9.0 & 20.3 & 13.1 & 16.8 \\
\hline 5 & - & - & - & 9.5 & 2.5 & 6.3 & 8.0 & 3.3 & 5.5 & 13.3 & 6.2 & 10.4 & 16.5 & 7.7 & 11.6 & 16.5 & 11.8 & 14.3 \\
\hline 6 & - & - & - & 2.4 & -3.0 & -.7 & 10.6 & 3.8 & 6.7 & 7.2 & 3.4 & 5.3 & 18.2 & 9.9 & 12.9 & 16.2 & 11.2 & 13.1 \\
\hline 7 & - & - & - & 1.2 & -4.3 & -1.2 & 8.6 & 3.4 & 5. & 13.1 & 1.6 & 7.5 & 18.6 & 11.0 & 13.9 & 15.5 & 9.4 & 12.7 \\
\hline 8 & - & - & - & -2.9 & -6.3 & -4.4 & 4.3 & 2.1 & 2.9 & 18 & 8.7 & 12.8 & 15.3 & 7.0 & 11.6 & 17.0 & 7.0 & 12.2 \\
\hline 9 & - & - & - & 8.1 & -6.7 & .0 & 8.3 & 2.1 & 4.1 & 15.5 & 9.8 & 12.6 & 10.3 & 6.3 & 8.6 & 7.4 & 4.2 & 5.5 \\
\hline 10 & - & - & - & 7.8 & .7 & 5.1 & 8.3 & 2.8 & 5.3 & 11.7 & 6.1 & 9.1 & 8.9 & 5.4 & 6.6 & 12.3 & 3.2 & 8.3 \\
\hline 11 & - & - & - & 7.0 & -.9 & 3.1 & 9.9 & 5.1 & 7.4 & 13.1 & 5.8 & 9.3 & 8.0 & 4.4 & 5.9 & 15.5 & 9.9 & 12.1 \\
\hline 12 & - & - & - & -.8 & -5.2 & -2.9 & 11.8 & 1 & 9. & 9 & & & 12. & & 7.9 & 13.6 & 6.9 & 10.8 \\
\hline 13 & - & - & - & 8.0 & -3.6 & 2.6 & 7.9 & 4.5 & 6. & 9.2 & 4.8 & 6.8 & 16.1 & 7.5 & 12.0 & 7.3 & -.1 & 4.1 \\
\hline 14 & - & - & - & 12.4 & 3.2 & 8.7 & 5.2 & 2.4 & 3.8 & 12.9 & 5.9 & 9.2 & 17. & 9.2 & 13.1 & 2.7 & -.2 & .7 \\
\hline 15 & - & - & - & 18.0 & 9.5 & 14.0 & 5.2 & 1.9 & 3.5 & 11.6 & 5.9 & 8.3 & 12.4 & 7.3 & 9.5 & 4.2 & .3 & 1.9 \\
\hline 16 & - & - & - & 16.7 & 12.8 & 14.6 & 6.8 & 2.3 & 4.8 & 15.5 & 6.3 & 10.7 & 13.4 & 5.3 & 8.6 & 2.8 & .1 & 1.5 \\
\hline 17 & - & - & - & 18.1 & 10.5 & 14.6 & 5.4 & .8 & 2.7 & 10 & 4.6 & 7.9 & 15.3 & 5.4 & 10.5 & 9.2 & 1.1 & 5.5 \\
\hline 18 & - & - & - & 15.1 & 9.3 & 12.3 & 7.4 & 1.3 & 4.1 & 11 & 3.2 & 6.9 & 18.2 & 9.4 & 13 & 8.9 & 3.2 & 5.8 \\
\hline 19 & - & - & - & 13.8 & 6.3 & 9.7 & 4.7 & 1.4 & 2.5 & 14.0 & 4.5 & 9.3 & 19.4 & 11.0 & 14.2 & 4.2 & 2.3 & 3.4 \\
\hline 20 & - & - & - & 8.2 & 3.9 & 5.2 & 7.0 & 1.3 & 4.0 & 18.9 & 9.1 & 13.8 & 18.5 & 10.7 & 14.6 & 4.0 & 1.7 & 2.8 \\
\hline 21 & - & - & - & 9.9 & 3.6 & 6.7 & 6.8 & 2.3 & 4.3 & 21.5 & 14.8 & 18.3 & 20.5 & 9.9 & 15.9 & 3.5 & .2 & 1.3 \\
\hline 22 & - & - & - & 7.9 & & 5. & 9.4 & 2.9 & 5. & & 15.1 & 18 & 13.7 & & 9.9 & & .5 & 4.4 \\
\hline 23 & - & - & - & 7.1 & 2.0 & 4.8 & 12.4 & 2.9 & 7.5 & 22.5 & 14.1 & 17.4 & 9.0 & 4.7 & 7.1 & 11.6 & 5.5 & 8.8 \\
\hline 24 & - & - & - & 6.2 & .6 & 3.2 & 15.1 & 8.0 & 11.8 & 20.7 & 12.5 & 16.0 & 8.9 & 4.0 & 6.4 & - & - & - \\
\hline 25 & - & - & - & 6.6 & -.3 & 1.6 & 18.2 & 10.2 & 15.0 & 18.1 & 9.7 & 13.7 & 15.7 & 7.1 & 11.2 & - & - & - \\
\hline 26 & 2.9 & -1.5 & 0.7 & 3.8 & -.8 & .2 & 21.3 & 10.1 & 15.7 & 18.9 & 10.0 & 13.2 & 17.9 & 10.6 & 13.2 & - & - & - \\
\hline 27 & 6.6 & -1.2 & 2.9 & 6.1 & -.5 & 1.4 & 19.2 & 9.5 & 14.9 & 17. & 9.0 & 13.1 & 17.8 & 11.2 & 14.4 & - & - & - \\
\hline 28 & 11.7 & 4.6 & 8.3 & 4.7 & .7 & 1.9 & 14.2 & 6.8 & 9.9 & 13.3 & 6.0 & 9.5 & 21.5 & 10.1 & 15.4 & - & - & - \\
\hline 29 & 8.5 & -5.3 & 2.9 & 8.3 & .1 & 2.8 & 14.6 & 8.3 & 11.2 & 9.1 & 4.1 & 6.0 & 11.5 & 1.0 & 4.3 & - & - & - \\
\hline 30 & 3.0 & -6.3 & -2.6 & & & 6.7 & 18.0 & 10.1 & 13.2 & 4.2 & 1.8 & 3.2 & 3.2 & .2 & 1.9 & - & - & - \\
\hline 31 & & & & 13.2 & 8.0 & 10.6 & & & & 9.3 & 1.3 & 5.3 & 10.8 & 1.3 & 6.8 & & & \\
\hline $\begin{array}{l}\text { Monthly } \\
\text { average }\end{array}$ & - & - & - & 7.9 & 1.0 & 4.4 & 10.3 & 4.3 & 7.1 & 14.6 & 7.5 & 10.8 & 14.1 & 6.7 & 10.2 & - & - & - \\
\hline
\end{tabular}


The air temperature sensors on the glacier were re-installed mid-May 2007 and each sensor operated through the end of the water year (figs. 2 and $\underline{6}$ ). During May 16 to September 30, when all three sensors were operating, 2-m-height air temperature averaged $5.7^{\circ} \mathrm{C}$ at site $\mathrm{S} 2070$, $6.0^{\circ} \mathrm{C}$ at site $\mathrm{S} 1840 \mathrm{P}-1$, and $7.4^{\circ} \mathrm{C}$ at mass balance site $\mathrm{S} 1670$ (tables 10-12).

Wind speed at the Hut during water years 2006 and 2007 exhibited similar seasonal patterns to those of previous years, with maximum speeds during November through March (figs. 7 and $\underline{8}$ ). The maximum of recorded hourly average wind speed for water year 2006 was $28.9 \mathrm{~m} / \mathrm{s}$ on February 4 . The windiest day recorded was February 17, when wind speed averaged $14.7 \mathrm{~m} / \mathrm{s}$ (table 13). The maximum of recorded hourly average wind speed for water year 2007 was $26.8 \mathrm{~m} / \mathrm{s}$ on March 11. The windiest day recorded was December 13 when wind speed averaged $16.3 \mathrm{~m} / \mathrm{s}$ (table 14). The wind speed sensor almost certainly was locked by ice during days for which average tabulated wind speed was $0.4 \mathrm{~m} / \mathrm{s}$, the starting threshold of the sensor, and wind speeds on those dates almost certainly were greater than the record indicates.

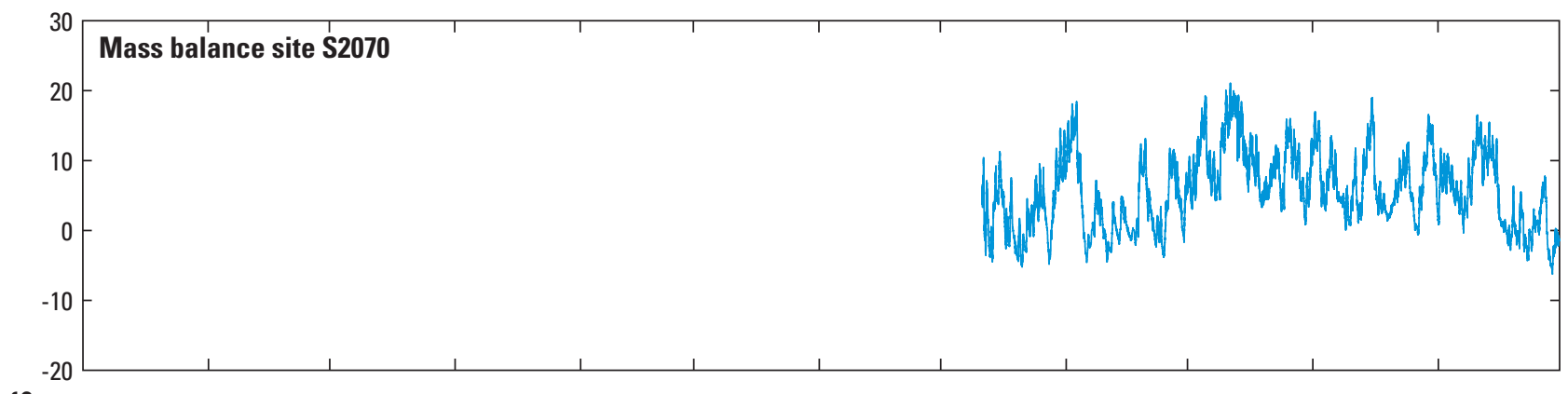

疍
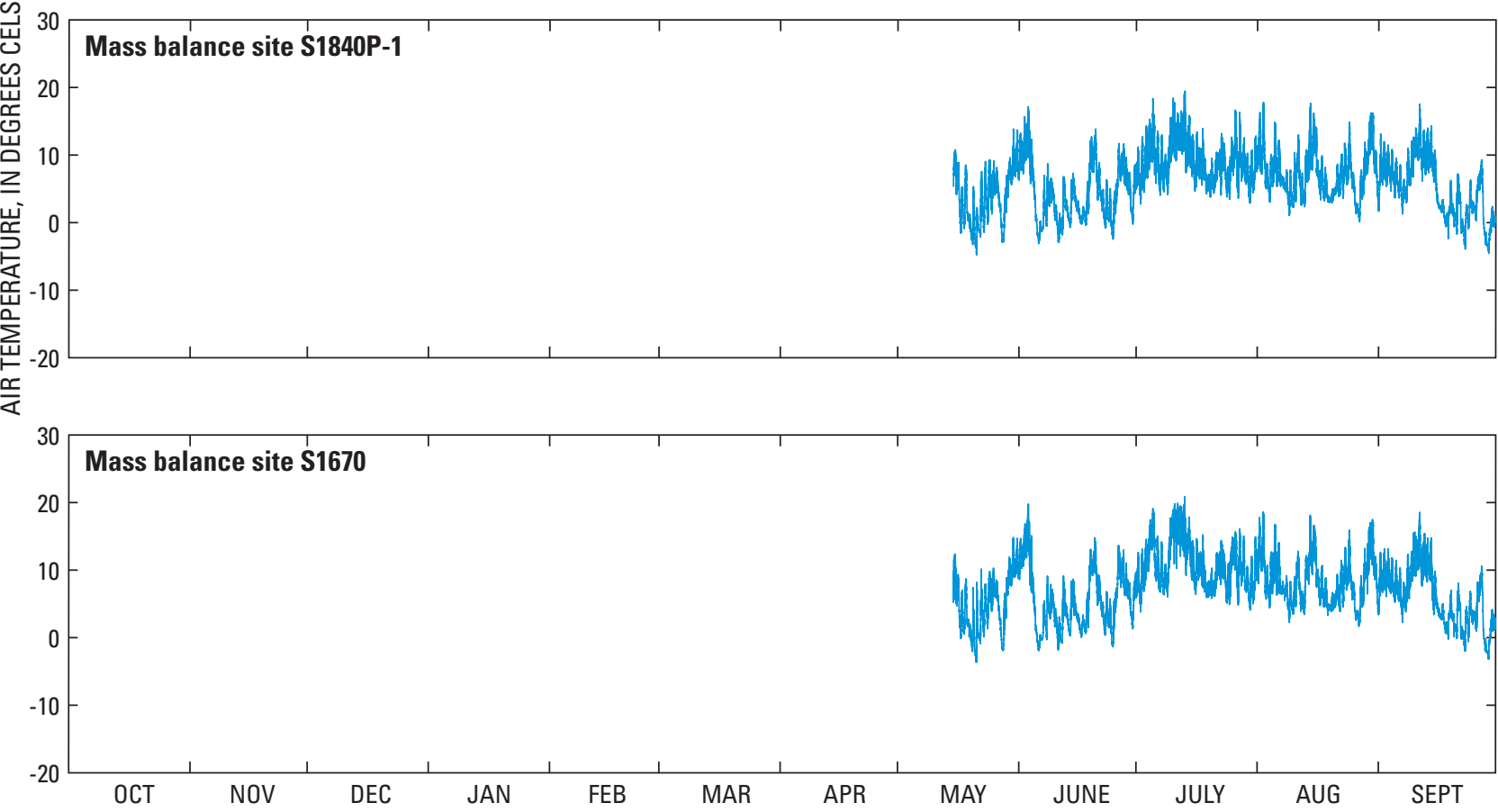

Figure 6. Air temperature at a height of 2 meters recorded at 10-minute intervals at three mass balance sites on South Cascade Glacier, Washington, May-September 2007. Daily summaries are presented in tables 10-12. Locations of mass balance sites are shown in figure 2. 
Table 10. Daily maximum, minimum, and average 2-meter-height air temperature at mass balance site S2070 on South Cascade Glacier, Washington, 2,066 meters altitude, May-September 2007.

[Abbreviations: Max, maximum; Min, minimum; Avg, average; -, insufficient data]

\begin{tabular}{|c|c|c|c|c|c|c|c|c|c|c|c|c|c|c|c|}
\hline \multirow{3}{*}{ Day } & \multicolumn{15}{|c|}{ Daily air temperature, in degrees Celsius } \\
\hline & \multicolumn{3}{|c|}{ May } & \multicolumn{3}{|c|}{ June } & \multicolumn{3}{|c|}{ July } & \multicolumn{3}{|c|}{ August } & \multicolumn{3}{|c|}{ September } \\
\hline & Max & Min & Avg & Max & Min & Avg & Max & Min & Avg & Max & Min & Avg & Max & Min & Avg \\
\hline 1 & - & - & - & 15.7 & 8.4 & 11.6 & 10.6 & 3.8 & 7.1 & 17.0 & 10.9 & 13.5 & 11.7 & 0.8 & 6.1 \\
\hline 2 & - & - & - & 18.1 & 11.1 & 13.9 & 10.9 & 3.1 & 6.4 & 15.7 & 7.1 & 12.8 & 11.0 & 5.5 & 7.6 \\
\hline 3 & - & - & - & 18.4 & 6.8 & 14.3 & 13.4 & 4.6 & 9.5 & 7.7 & 3.4 & 5.2 & 11.0 & 5.3 & 8.4 \\
\hline 4 & - & - & - & 11.1 & 3.4 & 7.7 & 17.5 & 10.7 & 13.9 & 8.8 & 2.8 & 5.7 & 9.3 & 4.5 & 6.7 \\
\hline 5 & - & - & - & 3.3 & -3.4 & -.5 & 19.3 & 8.1 & 14.7 & 13.5 & 7.6 & 10.4 & 7.1 & 3.6 & 5.2 \\
\hline 6 & - & - & - & -.6 & -4.6 & -2.6 & 11.5 & 5.0 & 8.5 & 11.5 & 5.6 & 7.9 & 7.1 & 2.3 & 4.1 \\
\hline 7 & - & - & - & 1.2 & -2.3 & -.3 & 11.2 & 4.3 & 7.7 & 5.7 & 3.9 & 4.8 & 4.9 & -.3 & 2.5 \\
\hline 8 & - & - & - & 7.2 & -.9 & 3.9 & 8.6 & 4.3 & 6.2 & 5.2 & 1.7 & 4.0 & 10.4 & 1.8 & 6.1 \\
\hline 9 & - & - & - & 5.7 & .7 & 3.7 & 15.4 & 4.4 & 11.9 & 6.4 & .1 & 2.7 & 12.9 & 3.7 & 8.1 \\
\hline 10 & - & - & - & 2.1 & -3.0 & -.5 & 20.0 & 11.1 & 15.3 & 6.7 & .7 & 2.9 & 16.5 & 10.3 & 13.0 \\
\hline 11 & - & - & - & -1.6 & -4.5 & -3.0 & 21.1 & 13.2 & 16.8 & 11.8 & 3.6 & 7.4 & 15.5 & 7.7 & 12.9 \\
\hline 12 & 7.1 & -3.5 & 1.4 & 4.1 & -3.1 & .4 & 20.0 & 16.3 & 17.8 & 4.0 & 1.1 & 2.6 & 13.5 & 6.4 & 10.3 \\
\hline 13 & .5 & -4.5 & -2.1 & 1.9 & -1.2 & .2 & 19.3 & 10.0 & 16.0 & 11.6 & 2.1 & 7.2 & 15.5 & 7.9 & 11.3 \\
\hline 14 & 9.3 & -.2 & 4.9 & 4.9 & -2.0 & 1.1 & 18.4 & 9.4 & 14.7 & 15.3 & 8.7 & 12.0 & 13.6 & 7.9 & 11.0 \\
\hline 15 & 11.3 & 3.7 & 7.1 & 4.7 & .7 & 2.4 & 13.0 & 6.6 & 10.1 & 19.0 & 11.5 & 15.2 & 13.1 & 2.4 & 8.3 \\
\hline 16 & 6.5 & -1.0 & 3.9 & .8 & -1.1 & -.3 & 14.0 & 5.5 & 10.4 & 15.6 & 4.0 & 8.0 & 3.8 & .6 & 1.4 \\
\hline 17 & 3.2 & -2.6 & -.3 & .4 & -1.4 & -.4 & 13.5 & 6.4 & 9.7 & 7.0 & 2.2 & 4.4 & 1.6 & -.5 & .4 \\
\hline 18 & 7.5 & -2.3 & 2.2 & 4.9 & -2.1 & .0 & 13.7 & 4.7 & 9.0 & 5.3 & 2.5 & 3.7 & .7 & -2.8 & -1.0 \\
\hline 19 & -.3 & -4.0 & -2.2 & 12.4 & 4.5 & 8.8 & 5.8 & 3.3 & 4.4 & 3.0 & 1.4 & 2.2 & 6.3 & -1.1 & 1.1 \\
\hline 20 & 1.7 & -4.7 & -2.5 & 13.2 & 5.8 & 9.6 & 7.7 & 4.4 & 6.0 & 4.1 & 1.8 & 3.0 & .9 & -2.1 & -.5 \\
\hline 21 & -.5 & -5.2 & -2.8 & 6.7 & 1.3 & 3.9 & 9.6 & 4.6 & 7.2 & 7.3 & 3.7 & 5.1 & 5.5 & -2.6 & 2.3 \\
\hline 22 & 4.5 & -3.1 & .3 & 3.0 & -1.4 & .9 & 12.2 & 7.4 & 9.3 & 10.3 & 4.6 & 7.5 & 2.0 & -3.4 & -1.6 \\
\hline 23 & 3.6 & -.8 & 1.4 & 2.1 & -2.4 & -.3 & 11.8 & 5.8 & 9.3 & 11.5 & 6.1 & 8.9 & .2 & -4.3 & -1.7 \\
\hline 24 & 7.9 & -.8 & 4.1 & 3.4 & -3.4 & -1.0 & 8.6 & 2.7 & 4.8 & 12.6 & 6.4 & 10.2 & 3.1 & -3.0 & .1 \\
\hline 25 & 9.6 & 1.3 & 4.8 & 4.3 & -3.9 & -.4 & 15.9 & 8.3 & 12.5 & 6.3 & 2.4 & 4.7 & 1.5 & -.6 & .7 \\
\hline 26 & 9.0 & 1.8 & 4.1 & 11.7 & 2.8 & 6.9 & 16.0 & 7.6 & 12.9 & 2.3 & -.6 & .6 & 6.9 & -.1 & 3.9 \\
\hline 27 & 1.8 & -4.8 & -1.3 & 11.6 & 7.5 & 9.9 & 14.4 & 7.3 & 10.9 & 6.3 & -.6 & 3.1 & 7.8 & -1.1 & 4.9 \\
\hline 28 & 5.7 & -4.0 & .3 & 10.0 & 3.9 & 6.2 & 12.5 & 5.8 & 9.1 & 11.2 & 4.9 & 8.6 & -1.2 & -5.1 & -3.7 \\
\hline 29 & 11.8 & 3.2 & 6.8 & 5.0 & -.6 & 2.4 & 7.6 & 2.3 & 5.3 & 16.6 & 9.2 & 13.1 & -.3 & -6.3 & -3.6 \\
\hline 30 & 14.6 & 5.6 & 9.2 & 8.3 & -1.7 & 3.5 & 8.3 & .8 & 4.1 & 15.3 & 8.5 & 12.9 & .3 & -2.4 & -1.2 \\
\hline 31 & 14.3 & 7.0 & 9.9 & & & & 13.2 & 4.4 & 8.8 & 9.6 & 1.4 & 6.4 & & & \\
\hline $\begin{array}{l}\text { Monthly } \\
\text { average }\end{array}$ & - & - & - & 6.5 & 0.5 & 3.4 & 13.4 & 6.3 & 10.0 & 9.8 & 4.2 & 7.0 & 7.1 & 1.2 & 4.1 \\
\hline
\end{tabular}


Table 11. Daily maximum, minimum, and average 2-meter-height air temperature at mass balance site S1840P-1 on South Cascade Glacier, Washington, 1,836 meters estimated altitude, May-September 2007.

[Abbreviations: Max, maximum; Min, minimum; Avg, average; -, insufficient data]

\begin{tabular}{|c|c|c|c|c|c|c|c|c|c|c|c|c|c|c|c|}
\hline \multirow{3}{*}{ Day } & \multicolumn{15}{|c|}{ Daily air temperature, in degrees Celsius } \\
\hline & \multicolumn{3}{|c|}{ May } & \multicolumn{3}{|c|}{ June } & \multicolumn{3}{|c|}{ July } & \multicolumn{3}{|c|}{ August } & \multicolumn{3}{|c|}{ September } \\
\hline & Max & Min & Avg & Max & Min & Avg & Max & Min & Avg & Max & Min & Avg & Max & Min & Avg \\
\hline 1 & - & - & - & 13.2 & 6.3 & 9.8 & 11.2 & 4.6 & 7.4 & 16.3 & 7.6 & 10.9 & 13.1 & 1.7 & 6.7 \\
\hline 2 & _- & _- & _- & 15.7 & 7.3 & 11.2 & 12.7 & 2.8 & 7.2 & 17.8 & 7.2 & 11.4 & 12.0 & 5.6 & 8.2 \\
\hline 3 & - & - & - & 17.1 & 7.3 & 12.3 & 14.3 & 4.5 & 8.7 & 14.2 & 5.0 & 6.7 & 11.5 & 5.3 & 8.1 \\
\hline 4 & - & - & - & 13.1 & 4.5 & 7.5 & 15.3 & 7.1 & 11.1 & 10.1 & 3.0 & 6.6 & 10.8 & 4.7 & 7.5 \\
\hline 5 & - & - & - & 7.0 & -2.1 & .9 & 18.4 & 7.1 & 12.2 & 14.9 & 6.0 & 9.8 & 9.5 & 3.7 & 6.7 \\
\hline 6 & - & - & - & .2 & -3.1 & -1.6 & 13.5 & 5.5 & 9.5 & 12.2 & 5.4 & 8.4 & 8.6 & 3.6 & 5.6 \\
\hline 7 & - & - & - & 7.0 & -1.1 & 1.3 & 13.0 & 4.1 & 8.0 & 10.5 & 5.1 & 6.1 & 7.0 & 1.3 & 4.0 \\
\hline 8 & - & - & - & 8.7 & -.5 & 3.6 & 10.3 & 4.6 & 7.3 & 7.8 & 3.2 & 5.5 & 11.0 & 2.9 & 6.7 \\
\hline 9 & - & - & - & 6.6 & 2.9 & 4.8 & 15.5 & 4.2 & 9.5 & 7.8 & 1.1 & 4.0 & 12.1 & 5.5 & 8.4 \\
\hline 10 & - & - & - & 5.0 & -1.5 & 1.2 & 18.4 & 9.1 & 13.1 & 10.4 & 2.3 & 4.4 & 14.0 & 9.6 & 11.3 \\
\hline 11 & - & - & - & 1.4 & -2.9 & -1.3 & 17.8 & 9.2 & 12.2 & 13.0 & 5.5 & 8.5 & 17.5 & 9.2 & 12.4 \\
\hline 12 & _- & - & _- & 6.8 & -1.8 & 2.7 & 16.5 & 10.2 & 12.7 & 9.3 & 2.6 & 4.3 & 14.9 & 6.2 & 10.1 \\
\hline 13 & - & - & - & 5.7 & .0 & 1.8 & 19.4 & 7.4 & 12.5 & 10.8 & 2.4 & 6.9 & 14.0 & 7.1 & 9.9 \\
\hline 14 & - & - & - & 7.3 & -.7 & 2.6 & 15.8 & 8.1 & 11.6 & 17.7 & 6.4 & 10.6 & 14.3 & 7.6 & 10.2 \\
\hline 15 & - & - & - & 7.3 & 1.7 & 3.8 & 13.0 & 6.3 & 9.7 & 16.2 & 7.8 & 11.7 & 10.7 & 3.6 & 7.5 \\
\hline 16 & 10.8 & 0.9 & 5.4 & 3.2 & -.1 & 1.2 & 13.4 & 4.7 & 8.2 & 14.2 & 5.1 & 8.3 & 6.7 & 2.0 & 2.7 \\
\hline 17 & 5.2 & -1.6 & 1.2 & 2.4 & -.2 & .9 & 11.1 & 5.5 & 8.7 & 9.9 & 3.4 & 6.2 & 3.4 & .6 & 1.9 \\
\hline 18 & 8.5 & -.9 & 3.3 & 6.0 & -.4 & 1.9 & 13.9 & 4.6 & 8.3 & 8.2 & 3.2 & 5.1 & 2.0 & -2.3 & .1 \\
\hline 19 & 3.9 & -2.3 & -.2 & 12.7 & 5.1 & 9.0 & 8.1 & 3.9 & 5.6 & 6.0 & 3.0 & 3.4 & 6.2 & 1.0 & 2.9 \\
\hline 20 & 5.3 & -3.6 & -.7 & 13.8 & 7.0 & 10.0 & 9.5 & 3.8 & 6.4 & 5.1 & 2.9 & 4.2 & 3.8 & -.6 & 1.0 \\
\hline 21 & 2.2 & -4.8 & -1.5 & 12.3 & 3.3 & 5.9 & 10.4 & 4.8 & 7.7 & 8.7 & 3.9 & 5.8 & 7.2 & -1.7 & 3.8 \\
\hline 22 & 7.6 & -2.1 & 2.1 & 7.2 & .0 & 2.6 & 13.2 & 4.1 & 9.0 & 10.1 & 4.0 & 7.0 & 4.6 & -2.1 & $\begin{array}{l}-.3 \\
-.3\end{array}$ \\
\hline 23 & 9.0 & -1.4 & 3.0 & 6.4 & -.8 & 1.9 & 13.2 & 6.3 & 9.4 & 11.8 & 3.6 & 8.0 & 2.7 & -3.9 & .1 \\
\hline 24 & 9.3 & -.2 & 5.0 & 5.0 & -1.9 & .7 & 9.4 & 3.4 & 5.9 & 14.9 & 5.6 & 9.5 & 6.3 & -.9 & 2.4 \\
\hline 25 & 9.1 & 1.3 & 5.3 & 5.7 & -2.4 & 1.3 & 12.6 & 4.7 & 9.3 & 11.6 & 4.1 & 6.2 & 3.3 & .5 & 1.9 \\
\hline 26 & 8.1 & 2.4 & 5.3 & 11.7 & 2.9 & 7.5 & 16.6 & 5.2 & 10.9 & 6.0 & 1.1 & 2.1 & 7.2 & .3 & 4.9 \\
\hline 27 & 5.0 & -2.9 & .2 & 11.7 & 6.0 & 8.6 & 16.3 & 3.6 & 9.4 & 7.8 & .1 & 3.9 & 9.3 & -.2 & 5.8 \\
\hline 28 & 7.0 & -2.8 & 1.4 & 11.7 & 4.8 & 6.8 & 12.5 & 6.1 & 8.8 & 11.9 & $\begin{array}{r}.1 \\
4.2\end{array}$ & 7.7 & 5.1 & -3.5 & $\begin{array}{r}.0 \\
-2.3\end{array}$ \\
\hline 29 & 9.6 & 3.7 & 6.6 & 7.5 & 1.3 & 4.1 & 10.3 & 3.8 & 6.8 & 15.2 & 7.2 & 10.5 & .7 & -4.6 & -2.0 \\
\hline 30 & 13.8 & 5.6 & 8.7 & 8.6 & -.2 & 4.2 & 10.7 & 2.9 & 6.2 & 16.2 & 8.5 & 12.9 & 2.4 & -.6 & .5 \\
\hline 31 & 13.7 & 6.5 & 9.3 & & & & 12.8 & 4.5 & 8.4 & 14.4 & 2.8 & 7.3 & & & \\
\hline $\begin{array}{l}\text { Monthly } \\
\text { average }\end{array}$ & - & - & - & 8.3 & 1.4 & 4.2 & 13.5 & 5.4 & 9.1 & 11.6 & 4.3 & 7.2 & 8.4 & 2.1 & 4.9 \\
\hline
\end{tabular}


Table 12. Daily maximum, minimum, and average 2-meter-height air temperature at mass balance site $S 1670$ on South Cascade Glacier, Washington, 1,668 meters altitude, May-September 2007.

[Abbreviations: Max, maximum; Min, minimum; Avg, average; -, insufficient data]

\begin{tabular}{|c|c|c|c|c|c|c|c|c|c|c|c|c|c|c|c|}
\hline \multirow{3}{*}{ Day } & \multicolumn{15}{|c|}{ Daily air temperature, in degrees Celsius } \\
\hline & \multicolumn{3}{|c|}{ May } & \multicolumn{3}{|c|}{ June } & \multicolumn{3}{|c|}{ July } & \multicolumn{3}{|c|}{ August } & \multicolumn{3}{|c|}{ September } \\
\hline & Max & Min & Avg & Max & Min & Avg & Max & Min & Avg & Max & Min & Avg & Max & Min & Avg \\
\hline 1 & - & - & - & 14.7 & 8.7 & 11.6 & 12.6 & 5.9 & 8.5 & 17.8 & 8.0 & 12.9 & 12.6 & 3.4 & 7.7 \\
\hline 2 & - & - & - & 16.8 & 10.6 & 13.5 & 13.1 & 3.8 & 8.2 & 18.6 & 9.9 & 13.0 & 13.2 & 6.8 & 9.5 \\
\hline 3 & - & - & - & 19.8 & 8.9 & 14.9 & 14.5 & 6.9 & 10.4 & 11.0 & 5.7 & 8.1 & 13.2 & 6.1 & 9.2 \\
\hline 4 & - & - & - & 15.1 & 5.2 & 8.8 & 17.4 & 9.8 & 13.7 & 12.7 & 4.4 & 8.0 & 11.8 & 6.6 & 8.7 \\
\hline 5 & - & - & - & 5.9 & -.9 & 1.8 & 19.1 & 10.4 & 14.9 & 16.8 & 7.7 & 11.8 & 11.5 & 5.3 & 8.1 \\
\hline 6 & - & - & - & .5 & -1.9 & -.8 & 15.0 & 7.3 & 10.9 & 14.1 & 6.3 & 9.6 & 10.3 & 4.4 & 7.2 \\
\hline 7 & - & - & - & 5.5 & -.3 & 2.1 & 14.1 & 6.8 & 9.4 & 8.4 & 6.4 & 7.2 & 8.2 & 2.4 & 5.4 \\
\hline 8 & - & - & - & 9.1 & -.3 & 3.6 & 10.9 & 6.3 & 8.6 & 9.2 & 4.3 & 6.8 & 12.3 & 3.8 & 8.0 \\
\hline 9 & - & - & - & 7.9 & 2.8 & 5.4 & 17.7 & 6.1 & 11.8 & 8.3 & 2.3 & 5.3 & 12.8 & 7.1 & 9.6 \\
\hline 10 & - & - & - & 5.0 & -.1 & 2.5 & 19.8 & 10.9 & 16.7 & 9.1 & 3.5 & 5.5 & 15.6 & 9.1 & 12.9 \\
\hline 11 & - & - & - & 3.1 & -1.8 & -.1 & 19.9 & 10.3 & 16.9 & 12.8 & 6.1 & 9.7 & 18.5 & 10.0 & 13.1 \\
\hline 12 & - & - & - & 9.2 & -.8 & 3.8 & 19.5 & 12.0 & 16.9 & 7.6 & 3.7 & 5.4 & 15.5 & 7.7 & 11.2 \\
\hline 13 & - & - & - & 5.1 & .9 & 3.0 & 20.9 & 9.2 & 15.4 & 12.2 & 3.4 & 8.2 & 14.7 & 8.2 & 11.4 \\
\hline 14 & - & - & - & 8.7 & .3 & 3.6 & 17.8 & 10.8 & 14.2 & 18.1 & 7.9 & 12.0 & 14.8 & 5.6 & 10.5 \\
\hline 15 & - & - & - & 8.4 & 2.9 & 5.0 & 14.3 & 8.3 & 11.6 & 16.6 & 9.3 & 13.4 & 9.8 & 3.4 & 6.6 \\
\hline 16 & 9.3 & 2.0 & 6.1 & 3.6 & .6 & 2.2 & 14.7 & 6.4 & 10.1 & 15.0 & 6.0 & 9.1 & 5.7 & 2.9 & 4.0 \\
\hline 17 & 7.0 & -.1 & 2.6 & 3.4 & .1 & 1.7 & 12.7 & 7.8 & 10.7 & 10.7 & 4.7 & 7.4 & 5.0 & 1.9 & 3.3 \\
\hline 18 & 8.8 & .6 & 4.2 & 6.7 & .6 & 2.9 & 15.2 & 6.8 & 9.8 & 8.8 & 4.5 & 6.2 & 3.1 & -.2 & 1.2 \\
\hline 19 & 2.8 & -1.0 & 1.2 & 13.1 & 5.7 & 10.0 & 8.5 & 6.0 & 7.0 & 5.0 & 3.3 & 4.5 & 7.0 & 2.6 & 4.2 \\
\hline 20 & 7.4 & -2.6 & .4 & 14.8 & 8.2 & 11.3 & 10.3 & 5.8 & 7.5 & 6.7 & 4.0 & 5.3 & 3.5 & .2 & 2.0 \\
\hline 21 & 8.2 & -3.6 & -.1 & 9.6 & 4.8 & 7.1 & 12.6 & 6.2 & 9.0 & 9.4 & 4.6 & 6.6 & 8.1 & -.1 & 4.3 \\
\hline 22 & 10.1 & -.9 & 3.1 & 6.2 & 1.2 & 3.8 & 14.4 & 7.9 & 10.6 & 11.4 & 3.9 & 7.7 & 5.0 & -.2 & .9 \\
\hline 23 & 7.9 & .1 & 4.1 & 6.8 & .4 & 3.0 & 13.8 & 8.2 & 10.9 & 13.3 & 4.6 & 9.1 & 4.6 & -2.0 & 1.7 \\
\hline 24 & 9.8 & 1.3 & 6.2 & 5.7 & -1.0 & 1.9 & 11.0 & 4.9 & 7.4 & 15.9 & 7.7 & 10.7 & 6.9 & -.6 & 3.4 \\
\hline 25 & 10.3 & 3.9 & 7.1 & 6.8 & -1.3 & 2.4 & 14.9 & 5.4 & 11.2 & 9.2 & 5.0 & 7.2 & 4.0 & 1.6 & 3.0 \\
\hline 26 & 8.5 & 3.9 & 6.5 & 13.7 & 5.4 & 9.6 & 15.6 & 7.4 & 12.6 & 4.8 & 2.3 & 3.4 & 8.2 & 1.0 & 5.4 \\
\hline 27 & 4.4 & -1.7 & 1.1 & 13.0 & 7.4 & 9.9 & 16.1 & 4.8 & 10.5 & 9.2 & 1.7 & 5.0 & 10.6 & .3 & 7.1 \\
\hline 28 & 8.9 & -1.9 & 2.6 & 11.0 & 6.2 & 7.7 & 15.0 & 7.0 & 10.4 & 13.2 & 4.7 & 8.7 & 0.7 & -2.2 & -1.2 \\
\hline 29 & 11.9 & 6.3 & 9.0 & 8.2 & 2.9 & 5.5 & 10.5 & 5.5 & 8.0 & 17.0 & 6.5 & 11.8 & 2.8 & -3.2 & -.6 \\
\hline 30 & 14.8 & 7.7 & 10.8 & 8.8 & 1.3 & 5.0 & 12.0 & 4.1 & 7.4 & 17.5 & 9.3 & 14.0 & 4.1 & 1.0 & 2.4 \\
\hline 31 & 14.7 & 8.8 & 11.1 & & & & 14.9 & 5.6 & 9.7 & 12.0 & 3.8 & 8.4 & & & \\
\hline $\begin{array}{l}\text { Monthly } \\
\text { average }\end{array}$ & - & - & - & 8.9 & 2.6 & 5.4 & 14.8 & 7.2 & 11.0 & 12.0 & 5.3 & 8.5 & 9.1 & 3.1 & 6.0 \\
\hline
\end{tabular}



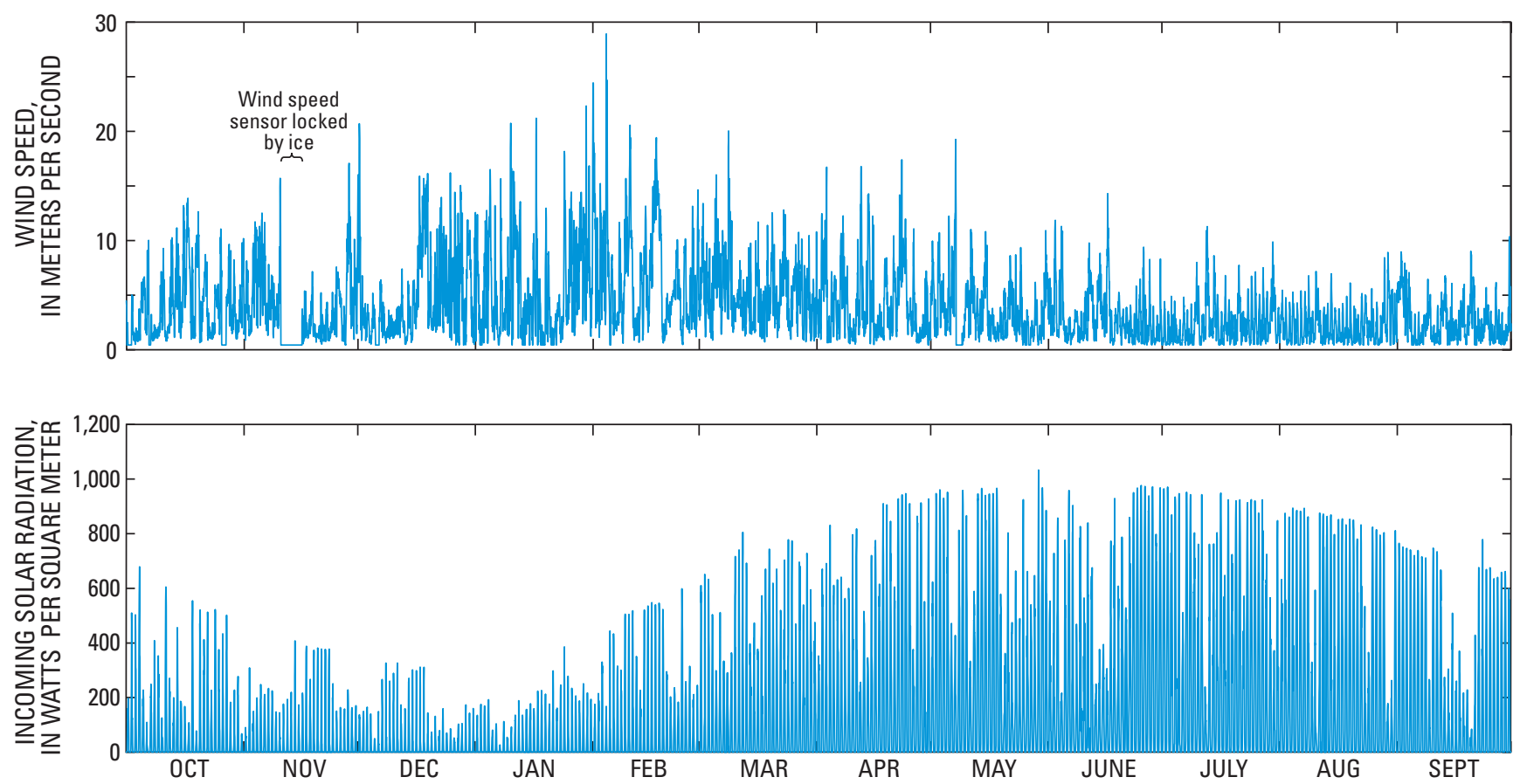

Figure 7. Hourly average wind speed and incoming solar radiation at the Hut, 1,842 meters altitude, near South Cascade Lake basin, Washington, water year 2006. Daily summaries are presented in tables 13 and 15.
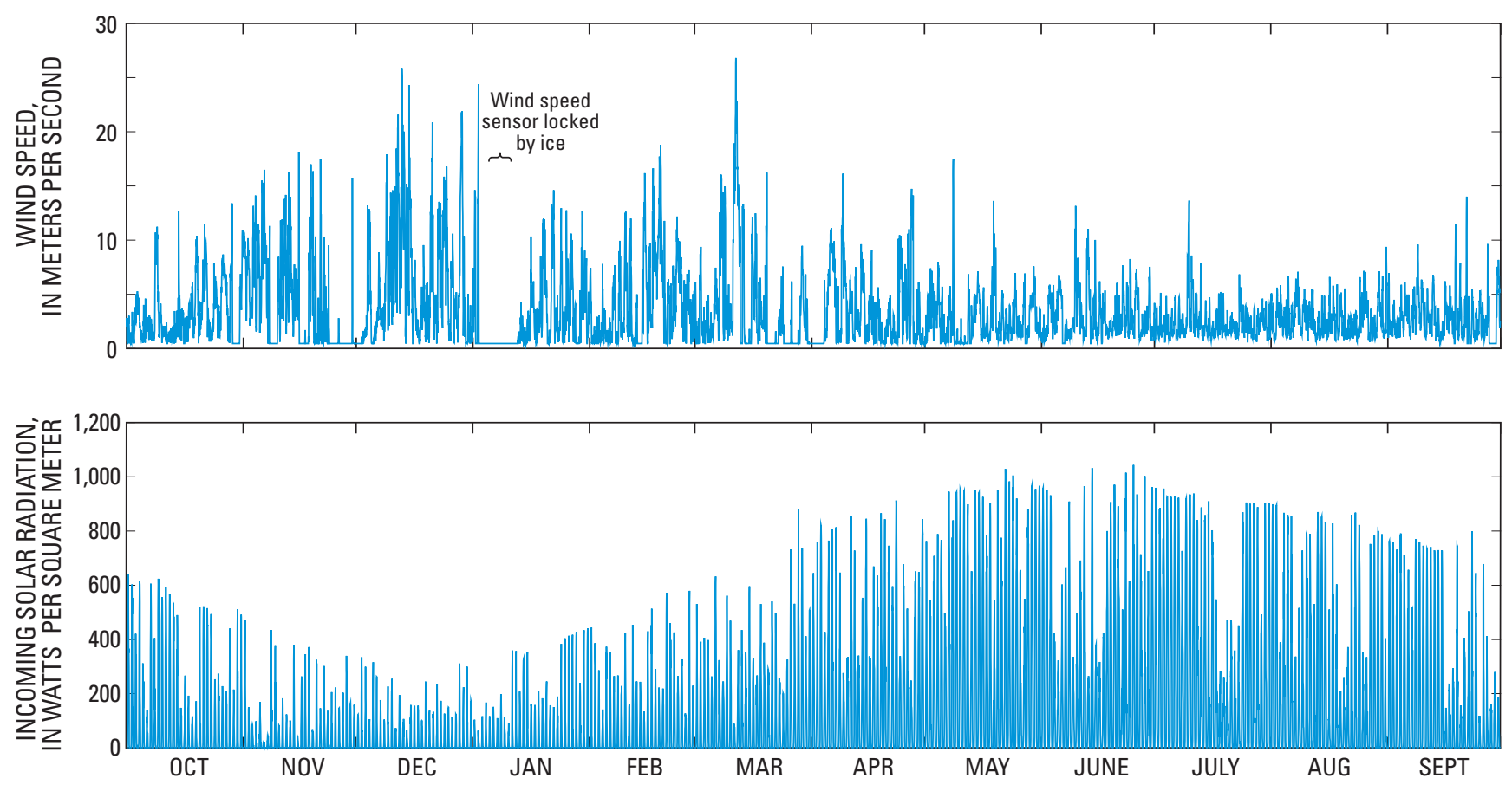

Figure 8. Hourly average wind speed and incoming solar radiation at the Hut, 1,842 meters altitude, near South Cascade Lake basin, Washington, water year 2007. Daily summaries are presented in tables 14 and $\underline{16}$. 
Table 13. Daily average wind speed at the Hut, 1,842 meters altitude, near South Cascade Lake basin, Washington, water year 2006.

[The wind speed sensor probably was locked by ice during days when tabulated wind speed was 0.4, the programmed starting speed of the sensor; the sensor might have been locked for parts of other days when temperature was at or below freezing, in which case, daily average wind speed would have been underestimated. Data are given in italics for days when the minimum air temperature was at or below 0 degrees Celsius]

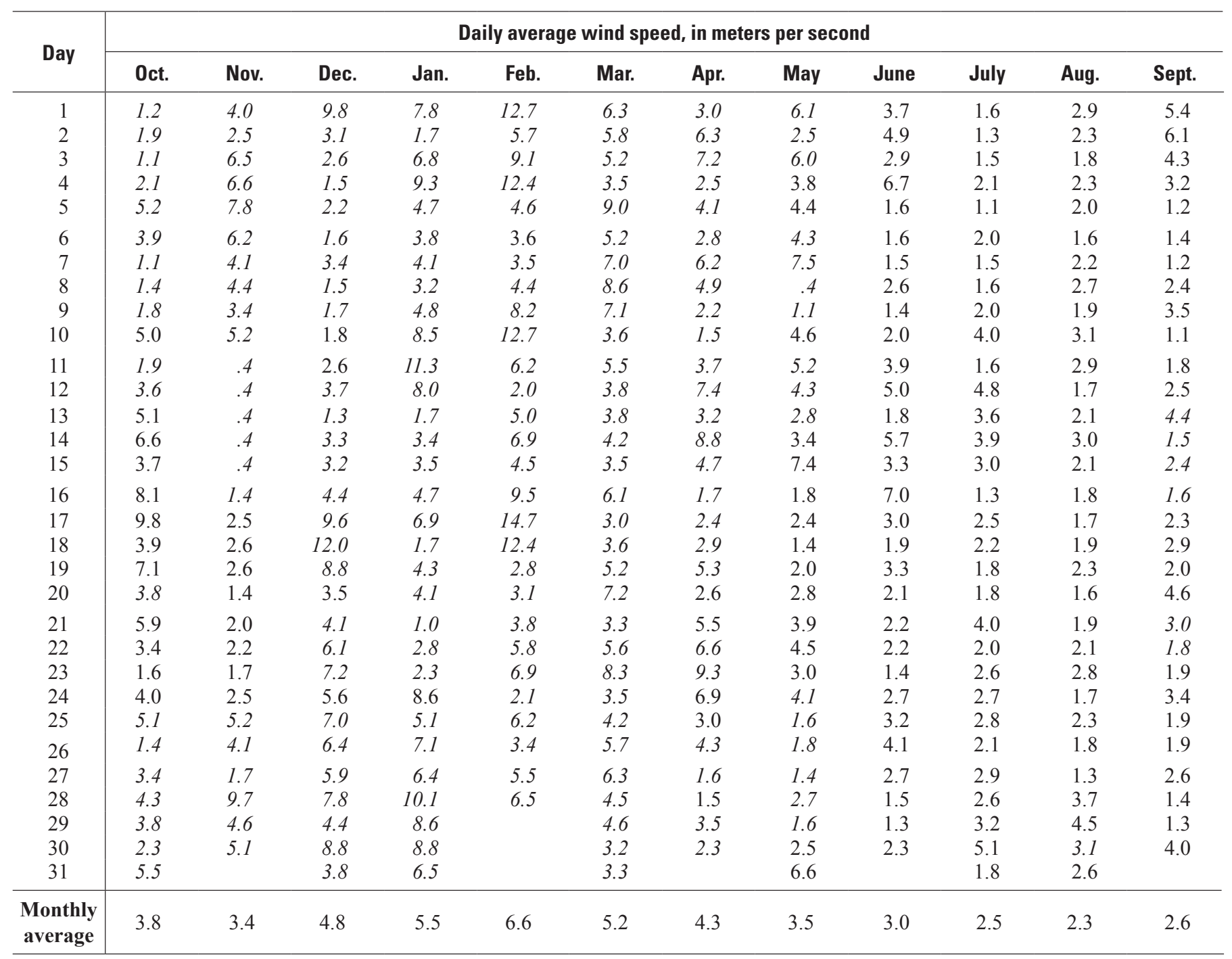


Table 14. Daily average wind speed at the Hut, 1,842 meters altitude, near South Cascade Lake basin, Washington, water year 2007.

[The wind speed sensor probably was locked by ice during days when tabulated wind speed was 0.4, the programmed starting speed of the sensor; the sensor might have been locked for parts of other days when temperature was at or below freezing, in which case, daily average wind speed would have been underestimated. Data are given in italics for days when the minimum air temperature was at or below 0 degrees Celsius]

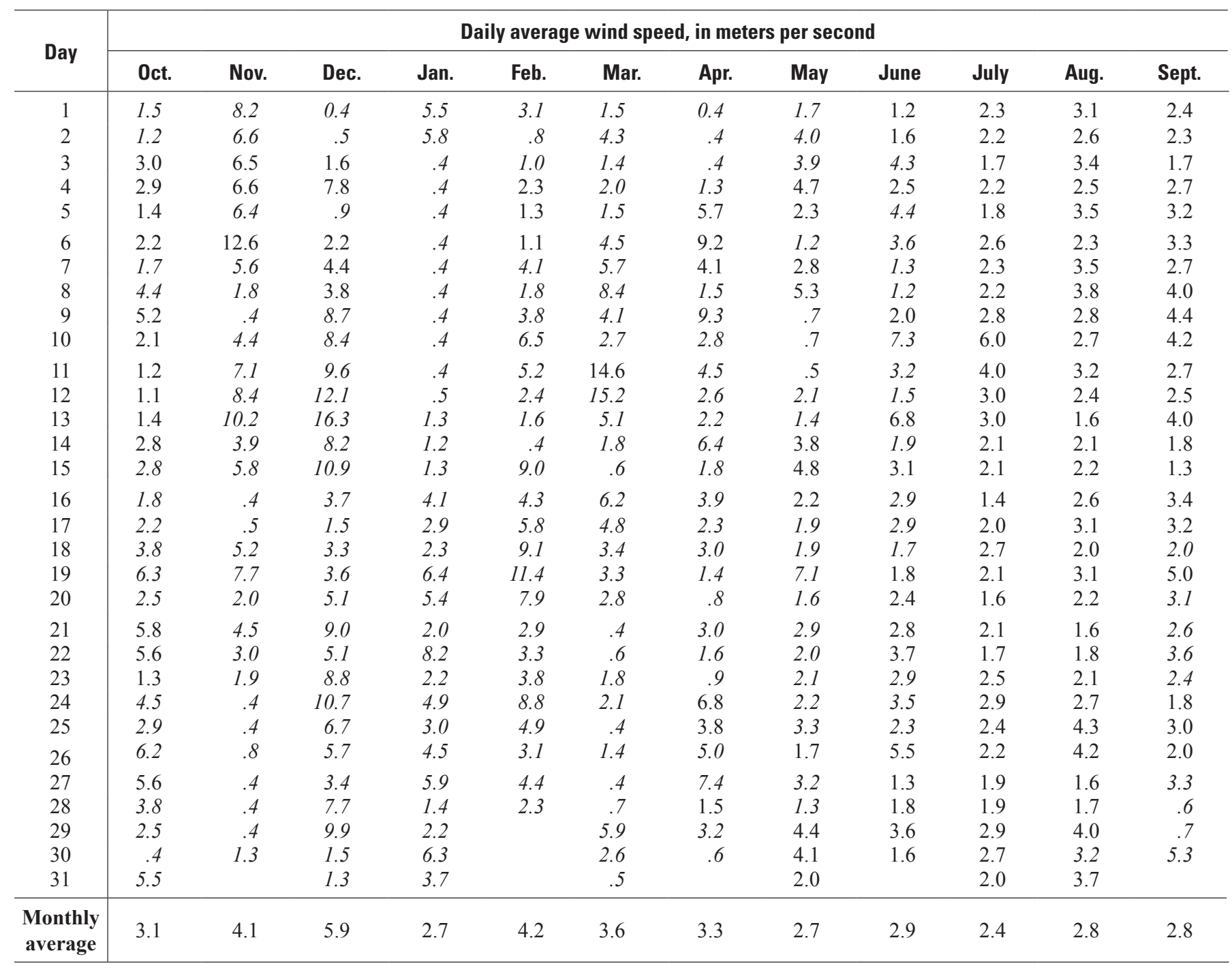


Complete records of incoming daily solar radiation measured at the Hut are available for water years 2006 and 2007 (figs. 7 and ), although ice and snow likely obscured the pyranometers and caused underestimation of solar radiation at times, particularly during winter. Maximum daily incoming solar radiation during water year 2006 was $369 \mathrm{~W} / \mathrm{m}^{2}$ on June 25, about the time of the summer solstice (table 15). Monthly average solar radiation ranged from $30 \mathrm{~W} / \mathrm{m}^{2}$ in December to $263 \mathrm{~W} / \mathrm{m}^{2}$ in July. Average daily incoming solar radiation averaged $223 \mathrm{~W} / \mathrm{m}^{2}$ during June through September, months when snow or ice accumulation on the pyranometers occurred infrequently, if at all. Maximum daily incoming solar radiation during water year 2007 was $365 \mathrm{~W} / \mathrm{m}^{2}$ on May 24, about 1 month before the summer solstice (table 16). Monthly average of incoming solar radiation ranged from $32 \mathrm{~W} / \mathrm{m}^{2}$ in December to $268 \mathrm{~W} / \mathrm{m}^{2}$ in May. Average daily incoming solar radiation averaged $207 \mathrm{~W} / \mathrm{m}^{2}$ during June through September.

Table 15. Daily average incoming solar radiation at the Hut, 1,842 meters altitude, near South Cascade Lake basin, Washington, water year 2006.

\begin{tabular}{|c|c|c|c|c|c|c|c|c|c|c|c|c|}
\hline \multirow{2}{*}{ Day } & \multicolumn{12}{|c|}{ Daily average incoming solar radiation, in watts per square meter averaged for the 24 -hour day } \\
\hline & Oct. & Nov. & Dec. & Jan. & Feb. & Mar. & Apr. & May & June & July & Aug. & Sept. \\
\hline 1 & 54 & 19 & 32 & 25 & 38 & 148 & 106 & 185 & 165 & 362 & 175 & 249 \\
\hline 2 & 90 & 56 & 32 & 33 & 45 & 97 & 202 & 330 & 145 & 362 & 241 & 245 \\
\hline 3 & 92 & 34 & 36 & 38 & 66 & 163 & 156 & 335 & 277 & 293 & 292 & 226 \\
\hline 4 & 174 & 45 & 23 & 42 & 37 & 120 & 228 & 317 & 86 & 257 & 252 & 204 \\
\hline 5 & 62 & 54 & 11 & 16 & 74 & 73 & 172 & 290 & 240 & 231 & 310 & 230 \\
\hline 6 & 17 & 53 & 22 & 22 & 91 & 97 & 179 & 147 & 323 & 155 & 311 & 234 \\
\hline 7 & 61 & 45 & 43 & 4 & 73 & 90 & 170 & 128 & 254 & 361 & 312 & 224 \\
\hline 8 & 86 & 49 & 49 & 20 & 57 & 71 & 131 & 227 & 133 & 350 & 281 & 217 \\
\hline 9 & 82 & 35 & 42 & 13 & 97 & 102 & 166 & 337 & 244 & 297 & 94 & 71 \\
\hline 10 & 26 & 19 & 46 & 17 & 99 & 156 & 192 & 273 & 166 & 218 & 91 & 236 \\
\hline 11 & 143 & 29 & 49 & 28 & 107 & 181 & 228 & 112 & 257 & 253 & 157 & 232 \\
\hline 12 & 59 & 35 & 29 & 31 & 88 & 185 & 86 & 220 & 220 & 63 & 292 & 204 \\
\hline 13 & 42 & 39 & 26 & 28 & 55 & 188 & 154 & 347 & 89 & 178 & 298 & 76 \\
\hline 14 & 93 & 72 & 50 & 30 & 102 & 124 & 110 & 347 & 98 & 235 & 288 & 70 \\
\hline 15 & 53 & 31 & 43 & 35 & 124 & 121 & 177 & 321 & 144 & 235 & 182 & 105 \\
\hline 16 & 35 & 43 & 40 & 34 & 127 & 99 & 246 & 341 & 99 & 351 & 268 & 58 \\
\hline 17 & 24 & 67 & 45 & 44 & 128 & 142 & 196 & 342 & 202 & 212 & 275 & 84 \\
\hline 18 & 131 & 51 & 45 & 44 & 129 & 132 & 292 & 359 & 239 & 281 & 280 & 53 \\
\hline 19 & 16 & 62 & 23 & 37 & 122 & 221 & 269 & 193 & 168 & 249 & 290 & 61 \\
\hline 20 & 110 & 63 & 14 & 34 & 71 & 140 & 233 & 109 & 232 & 337 & 289 & 23 \\
\hline 21 & 91 & 62 & 22 & 52 & 50 & 149 & 183 & 219 & 192 & 338 & 243 & 70 \\
\hline 22 & 111 & 61 & 13 & 37 & 62 & 147 & 312 & 121 & 253 & 204 & 249 & 187 \\
\hline 23 & 43 & 60 & 25 & 52 & 47 & 159 & 321 & 169 & 362 & 332 & 102 & 190 \\
\hline 24 & 123 & 44 & 15 & 69 & 134 & 135 & 302 & 135 & 366 & 335 & 107 & 200 \\
\hline 25 & 71 & 28 & 15 & 42 & 68 & 187 & 297 & 238 & 369 & 326 & 273 & 198 \\
\hline 26 & 73 & 30 & 12 & 47 & 72 & 132 & 113 & 184 & 368 & 321 & 269 & 187 \\
\hline 27 & 106 & 27 & 21 & 44 & 54 & 198 & 260 & 181 & 362 & 303 & 271 & 185 \\
\hline 28 & 38 & 51 & 20 & 38 & 47 & 138 & 302 & 171 & 367 & 239 & 263 & 189 \\
\hline 29 & 33 & 35 & 31 & 47 & & 202 & 138 & 265 & 314 & 170 & 54 & 188 \\
\hline 30 & 60 & 36 & 28 & 36 & & 166 & 253 & 360 & 364 & 92 & 64 & 159 \\
\hline 31 & 15 & & 34 & 43 & & 125 & & 255 & & 225 & 265 & \\
\hline $\begin{array}{c}\text { Monthly } \\
\text { average }\end{array}$ & 71 & 45 & 30 & 35 & 81 & 142 & 206 & 244 & 237 & 263 & 230 & 162 \\
\hline
\end{tabular}


The largest water year 2006 precipitation event measured by the precipitation gage at the Salix Creek gaging station occurred during December 23-25. The gaged precipitation total of the event was $70.9 \mathrm{~mm}$. Air temperature increased from less than to greater than $0^{\circ} \mathrm{C}$ as recorded precipitation began on December 23 and air temperature decreased to less than $0^{\circ} \mathrm{C}$ as gaged precipitation ceased on December 25; therefore, the recorded storm total could be in error due to the freezing conditions. The combination of rain and snow melt caused Salix Creek to be at its highest stage of the water year (fig. 9). Large winter snow storms also possibly occurred during the year that were not detected by the unheated precipitation gage. During June through September, when most precipitation likely was rain at the Salix Creek gaging station, total recorded precipitation was $216.1 \mathrm{~mm}$ (table 17).

Table 16. Daily average incoming solar radiation at the Hut, 1,842 meters altitude, near South Cascade Lake basin, Washington, water year 2007.

\begin{tabular}{|c|c|c|c|c|c|c|c|c|c|c|c|c|}
\hline \multirow{2}{*}{ Day } & \multicolumn{12}{|c|}{ Daily average incoming solar radiation, in watts per square meter averaged for the 24 -hour day } \\
\hline & Oct. & Nov. & Dec. & Jan. & Feb. & Mar. & Apr. & May & June & July & Aug. & Sept. \\
\hline 1 & 162 & 93 & 27 & 21 & 81 & 97 & 161 & 184 & 353 & 306 & 322 & 250 \\
\hline 2 & 132 & 29 & 53 & 10 & 75 & 100 & 148 & 139 & 350 & 341 & 323 & 184 \\
\hline 3 & 102 & 19 & 43 & 20 & 55 & 94 & 260 & 224 & 311 & 338 & 138 & 177 \\
\hline 4 & 156 & 13 & 27 & 27 & 31 & 102 & 116 & 218 & 118 & 354 & 211 & 207 \\
\hline 5 & 72 & 35 & 48 & 22 & 78 & 63 & 221 & 257 & 102 & 347 & 273 & 189 \\
\hline 6 & 31 & 6 & 47 & 27 & 74 & 166 & 215 & 169 & 174 & 348 & 227 & 191 \\
\hline 7 & 158 & 10 & 33 & 18 & 54 & 66 & 223 & 288 & 233 & 340 & 101 & 161 \\
\hline 8 & 63 & 52 & 20 & 38 & 44 & 68 & 142 & 245 & 284 & 227 & 124 & 247 \\
\hline 9 & 166 & 67 & 32 & 20 & 52 & 131 & 82 & 343 & 101 & 350 & 172 & 241 \\
\hline 10 & 151 & 20 & 39 & 15 & 89 & 94 & 116 & 339 & 124 & 355 & 219 & 234 \\
\hline 11 & 155 & 39 & 18 & 56 & 33 & 23 & 264 & 332 & 193 & 350 & 236 & 233 \\
\hline 12 & 148 & 28 & 32 & 56 & 76 & 84 & 169 & 280 & 312 & 278 & 100 & 232 \\
\hline 13 & 129 & 25 & 24 & 44 & 59 & 104 & 110 & 217 & 97 & 248 & 284 & 229 \\
\hline 14 & 102 & 69 & 13 & 54 & 54 & 98 & 147 & 333 & 328 & 308 & 296 & 227 \\
\hline 15 & 31 & 10 & 30 & 60 & 28 & 132 & 235 & 330 & 126 & 192 & 279 & 215 \\
\hline 16 & 43 & 47 & 34 & 37 & 90 & 90 & 115 & 302 & 97 & 300 & 76 & 39 \\
\hline 17 & 47 & 60 & 32 & 34 & 108 & 74 & 189 & 253 & 129 & 154 & 239 & 72 \\
\hline 18 & 31 & 68 & 24 & 39 & 64 & 112 & 182 & 267 & 265 & 67 & 152 & 81 \\
\hline 19 & 33 & 16 & 41 & 37 & 49 & 90 & 230 & 132 & 319 & 90 & 54 & 175 \\
\hline 20 & 97 & 50 & 26 & 48 & 54 & 89 & 230 & 226 & 350 & 98 & 65 & 46 \\
\hline 21 & 128 & 33 & 27 & 32 & 141 & 123 & 225 & 209 & 297 & 132 & 107 & 106 \\
\hline 22 & 122 & 52 & 34 & 33 & 106 & 112 & 184 & 355 & 113 & 105 & 215 & 78 \\
\hline 23 & 115 & 31 & 30 & 40 & 90 & 78 & 301 & 287 & 248 & 98 & 221 & 160 \\
\hline 24 & 52 & 41 & 21 & 69 & 67 & 41 & 119 & 365 & 162 & 268 & 273 & 189 \\
\hline 25 & 65 & 44 & 29 & 74 & 93 & 88 & 193 & 306 & 304 & 333 & 77 & 33 \\
\hline 26 & 56 & 33 & 23 & 71 & 37 & 217 & 135 & 163 & 341 & 330 & 68 & 129 \\
\hline 27 & 52 & 40 & 25 & 76 & 138 & 121 & 76 & 144 & 256 & 315 & 196 & 74 \\
\hline 28 & 73 & 61 & 47 & 76 & 52 & 181 & 232 & 316 & 204 & 279 & 258 & 44 \\
\hline 29 & 42 & 35 & 39 & 48 & & 220 & 183 & 361 & 148 & 141 & 262 & 72 \\
\hline 30 & 108 & 35 & 47 & 78 & & 124 & 253 & 360 & 345 & 285 & 259 & 48 \\
\hline 31 & 101 & & 33 & 79 & & 151 & & 355 & & 326 & 77 & \\
\hline $\begin{array}{l}\text { Monthly } \\
\text { average }\end{array}$ & 94 & 39 & 32 & 44 & 70 & 108 & 182 & 268 & 226 & 258 & 190 & 152 \\
\hline
\end{tabular}



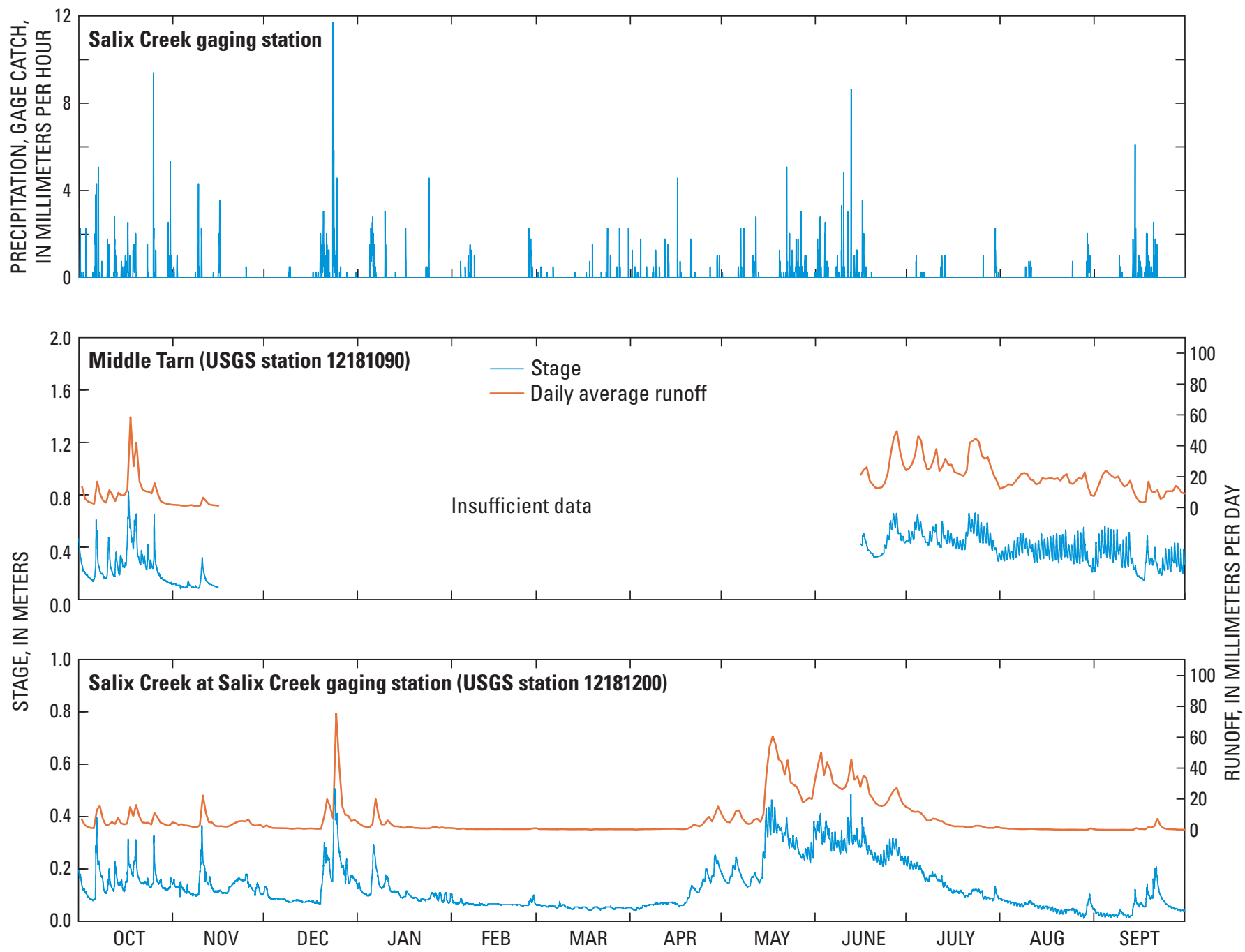

Figure 9. Hourly precipitation (gage catch) at the Salix Creek gaging station, stage of Middle Tarn and Salix Creek, and daily average runoff from Middle Tarn and Salix Creek basins, Washington, water year 2006. Stage was recorded every 15 minutes. Daily summaries of precipitation and runoff are presented in tables 17, $\underline{18}$, and $\underline{20}$. 
Table 17. Daily total precipitation (gage catch) at the Salix Creek gaging station, Salix Creek basin, Washington, 1,587 meters altitude, water year 2006 .

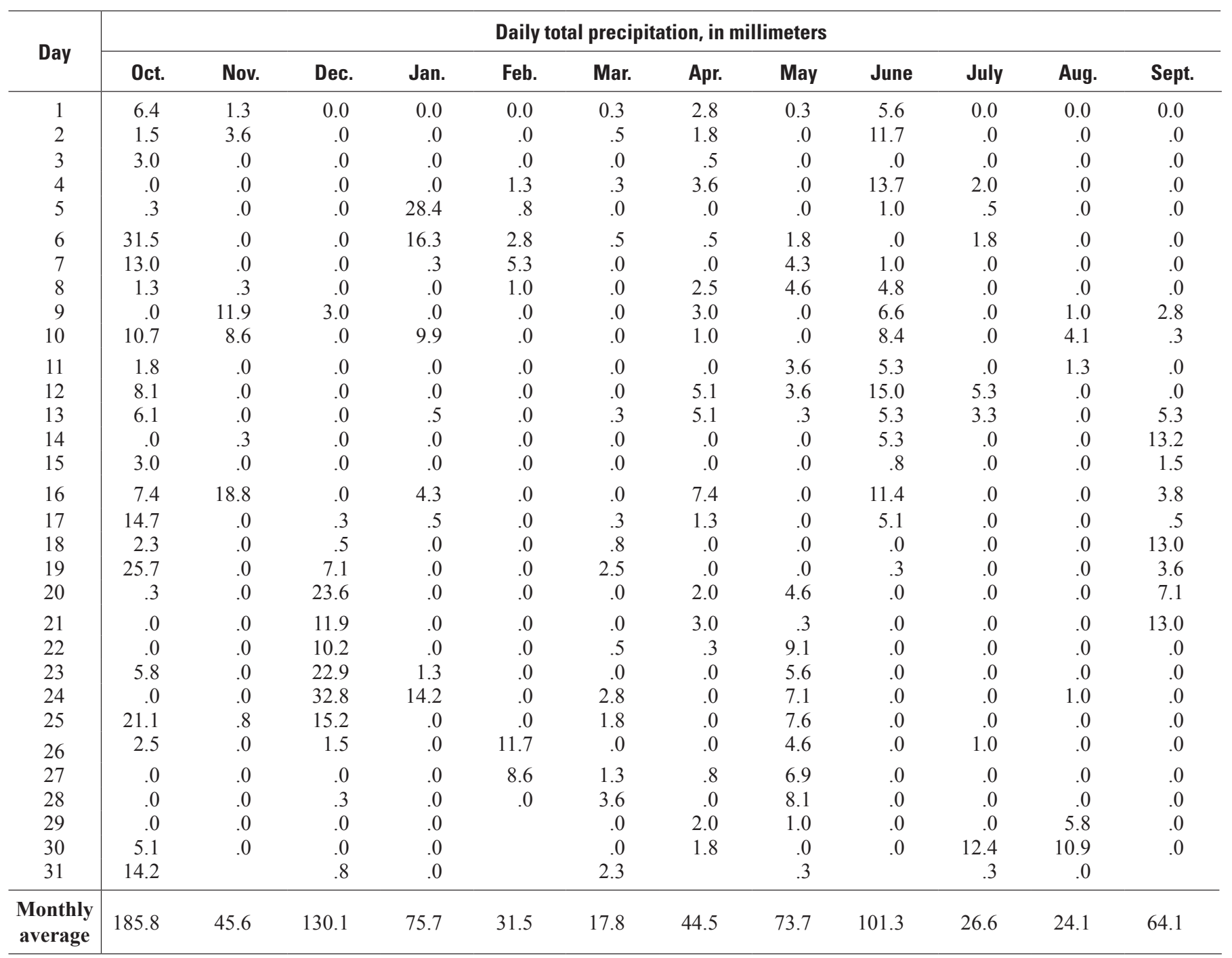


A partial record of runoff from Middle Tarn basin is available for water year 2006. Gaged daily average runoff from Middle Tarn basin during water year 2006 ranged from $1.2 \mathrm{~mm} / \mathrm{d}$ during early and mid November to $58.6 \mathrm{~mm} / \mathrm{d}$ on October 17 (table 18). Monthly average runoff for months of complete records ranged from $11.2 \mathrm{~mm} / \mathrm{d}$ in October to $29.8 \mathrm{~mm} / \mathrm{d}$ in July. The ratio of monthly Middle Tarn basin runoff to precipitation recorded at the Salix Creek gaging station decreased from about 35-to-1 for July to about 6-to-1 for September (fig. 10). Total runoff during June 15 to September 30 was 2,245 mm, which was about 17 times as great as measured precipitation during the same period. Discharge computed from two water year 2006 measurements differed from the rating curve by less than 5 percent when rating shifts were applied (table 19).

Table 18. Daily average runoff from Middle Tarn basin, Washington, October and November, and June-September, water year 2006.

\begin{tabular}{|c|c|c|c|c|c|c|}
\hline \multirow{3}{*}{ Day } & \multicolumn{6}{|c|}{$\begin{array}{l}\text { Daily average runoff, in millimeters averaged over the area of the basin } \\
\qquad \text { (4.46 square kilometers) }\end{array}$} \\
\hline & \multicolumn{2}{|c|}{2005} & \multicolumn{4}{|c|}{2006} \\
\hline & October & November & June & July & August & September \\
\hline 1 & 13.6 & 1.8 & - & 25.4 & 13.1 & 11.6 \\
\hline 2 & 5.8 & 1.6 & - & 28.3 & 13.8 & 16.9 \\
\hline 3 & 4.0 & 1.3 & - & 34.2 & 15.1 & 21.7 \\
\hline 4 & 3.1 & 1.2 & - & 46.6 & 14.5 & 24.0 \\
\hline 5 & 2.5 & 1.3 & - & 43.3 & 16.7 & 22.1 \\
\hline 6 & 16.9 & 1.7 & - & 31.1 & 19.2 & 20.3 \\
\hline 7 & 8.9 & 1.2 & - & 24.5 & 21.7 & 19.3 \\
\hline 8 & 4.5 & 1.2 & - & 25.6 & 22.5 & 20.2 \\
\hline 9 & 3.2 & 1.2 & - & 30.2 & 21.8 & 16.6 \\
\hline 10 & 11.4 & 6.5 & - & 37.9 & 18.2 & 13.6 \\
\hline 11 & 8.3 & 4.1 & - & 23.7 & 17.6 & 14.7 \\
\hline 12 & 4.2 & 2.1 & - & 26.7 & 15.0 & 17.5 \\
\hline 13 & 9.7 & 1.7 & - & 31.7 & 15.9 & 11.0 \\
\hline 14 & 7.9 & 1.4 & - & 27.7 & 19.2 & 6.5 \\
\hline 15 & 8.2 & 1.2 & 21.2 & 27.8 & 18.5 & 4.0 \\
\hline 16 & 11.3 & - & 24.3 & 23.0 & 18.8 & 3.3 \\
\hline 17 & 58.6 & - & 26.2 & 22.4 & 19.0 & 3.9 \\
\hline 18 & 26.7 & - & 17.4 & 21.4 & 18.4 & 16.9 \\
\hline 19 & 42.0 & - & 14.9 & 20.5 & 19.0 & 10.4 \\
\hline 20 & 16.8 & - & 12.7 & 24.0 & 17.5 & 10.0 \\
\hline 21 & 11.6 & - & 12.6 & 42.0 & 20.4 & 11.4 \\
\hline 22 & 10.6 & - & 13.2 & 43.2 & 21.7 & 5.6 \\
\hline 23 & 10.3 & - & 15.9 & 44.7 & 16.2 & 6.9 \\
\hline 24 & 9.2 & - & 22.5 & 42.7 & 15.3 & 10.6 \\
\hline 25 & 15.9 & - & 35.6 & 33.3 & 17.1 & 10.7 \\
\hline 26 & 8.9 & - & 45.7 & 31.6 & 19.4 & 10.6 \\
\hline 27 & 4.2 & - & 49.6 & 32.6 & 18.4 & 14.1 \\
\hline 28 & 3.1 & - & 36.7 & 26.3 & 22.8 & 12.6 \\
\hline 29 & 2.5 & - & 28.1 & 20.8 & 13.7 & 9.7 \\
\hline 30 & 2.1 & - & 24.2 & 17.1 & 8.2 & 9.2 \\
\hline 31 & 1.9 & - & & 12.1 & 7.5 & \\
\hline $\begin{array}{l}\text { Monthly } \\
\text { average }\end{array}$ & 11.2 & - & - & 29.8 & 17.3 & 12.9 \\
\hline
\end{tabular}




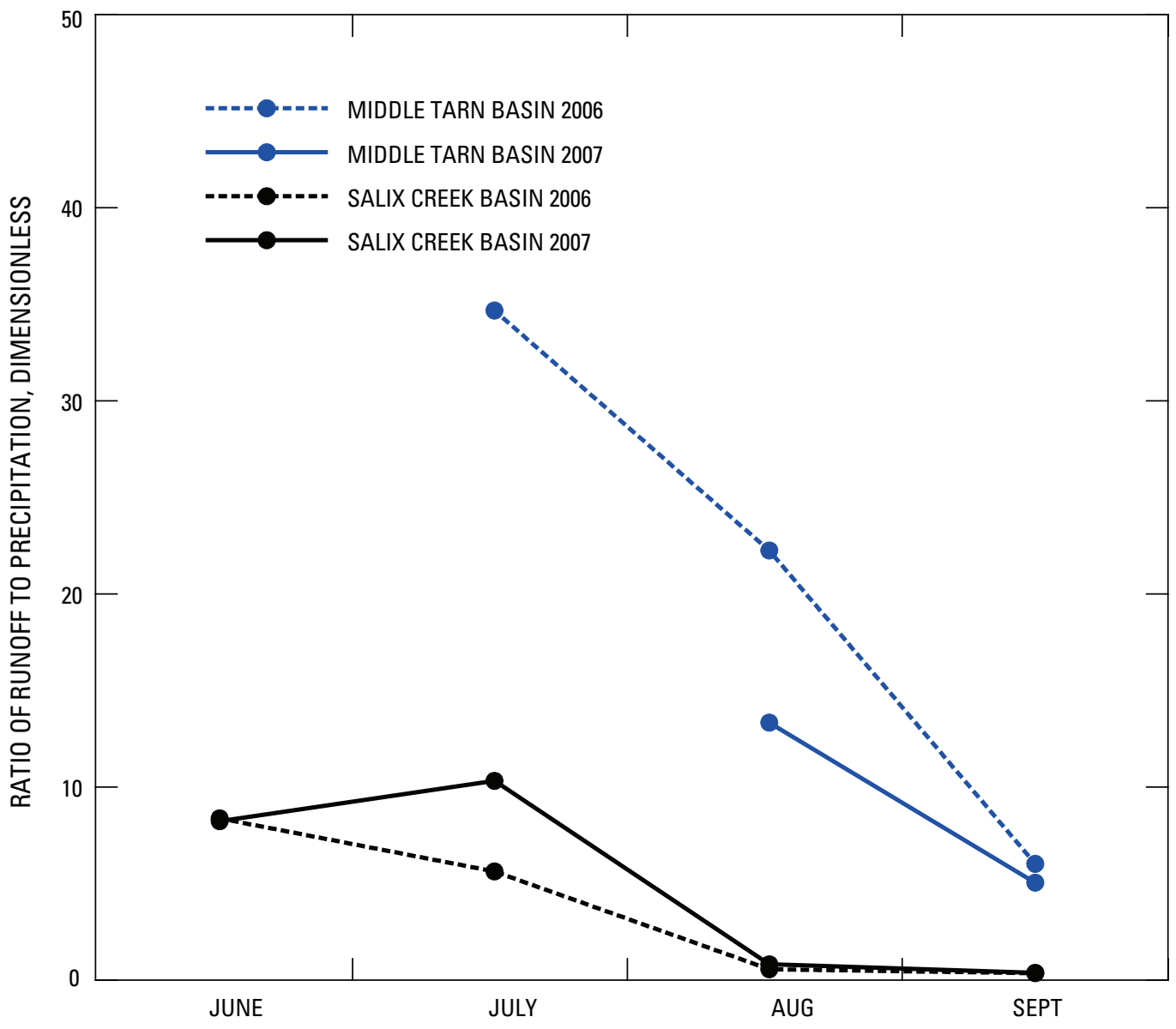

Figure 10. Ratio of monthly Middle Tarn and Salix Creek basin runoff to monthly precipitation (gage catch) at the Salix Creek gaging station, Washington, June-September, water years 2006 and 2007.

Table 19. Miscellaneous stream discharge measurements made at Middle Tarn outlet, South Fork of Cascade River, and Salix Creek near Salix Creek gaging station, Washington, water years 2006 and 2007.

[Abbreviations: $\mathrm{m}$, meter; $\mathrm{m}^{3} / \mathrm{s}$, cubic meter per second]

\begin{tabular}{|c|c|c|c|}
\hline \multirow[b]{2}{*}{ Date } & \multicolumn{3}{|c|}{ Stream measurement } \\
\hline & $\begin{array}{l}\text { Stage } \\
(\mathrm{m})\end{array}$ & $\begin{array}{c}\text { Discharge } \\
\left(\mathrm{m}^{3} / \mathrm{s}\right)\end{array}$ & $\begin{array}{c}\text { Type of } \\
\text { measurement }\end{array}$ \\
\hline \multicolumn{4}{|c|}{ South Fork of Cascade River at Middle Tarn outlet (12181090) } \\
\hline $09-10-06$ & 0.250 & 0.374 & Current meter \\
\hline $09-25-06$ & .241 & .368 & Current meter \\
\hline 08-01-07 & .390 & 1.147 & Current meter \\
\hline \multicolumn{4}{|c|}{ Salix Creek near Salix Creek gaging station (12181200) } \\
\hline $09-25-06$ & 0.061 & 0.001 & Volumetric \\
\hline
\end{tabular}


A complete record of runoff from Salix Creek basin is available for water year 2006. Daily average runoff at the Salix Creek gaging station ranged from less than $0.1 \mathrm{~mm} / \mathrm{d}$ on several days during late August through mid-September to $75.5 \mathrm{~mm} / \mathrm{d}$ on December 24 (table 20). Monthly average runoff ranged from $0.4 \mathrm{~mm} / \mathrm{d}$ in March and August to $28.3 \mathrm{~mm} / \mathrm{d}$ during July. Total water year runoff was 2,496 mm. The ratio of monthly basin runoff to precipitation recorded at the Salix Creek gaging station decreased from about 8-to-1 for June to less than 1-to-1 for August and September (fig. 10). Total runoff during June through September was 1,035 mm, which was about 5 times as large as measured precipitation during the same period. Discharge measured September 25 was 10 percent greater than was indicated by the rating curve; however, the absolute difference ( 0.0001 cubic meters per second) (table 19) was within the margin of measurement error.

Table 20. Daily average runoff from Salix Creek basin at the Salix Creek gaging station, Washington, water year 2006.

[Daily runoff less than 0.1 millimeters is tabulated as 0 ]

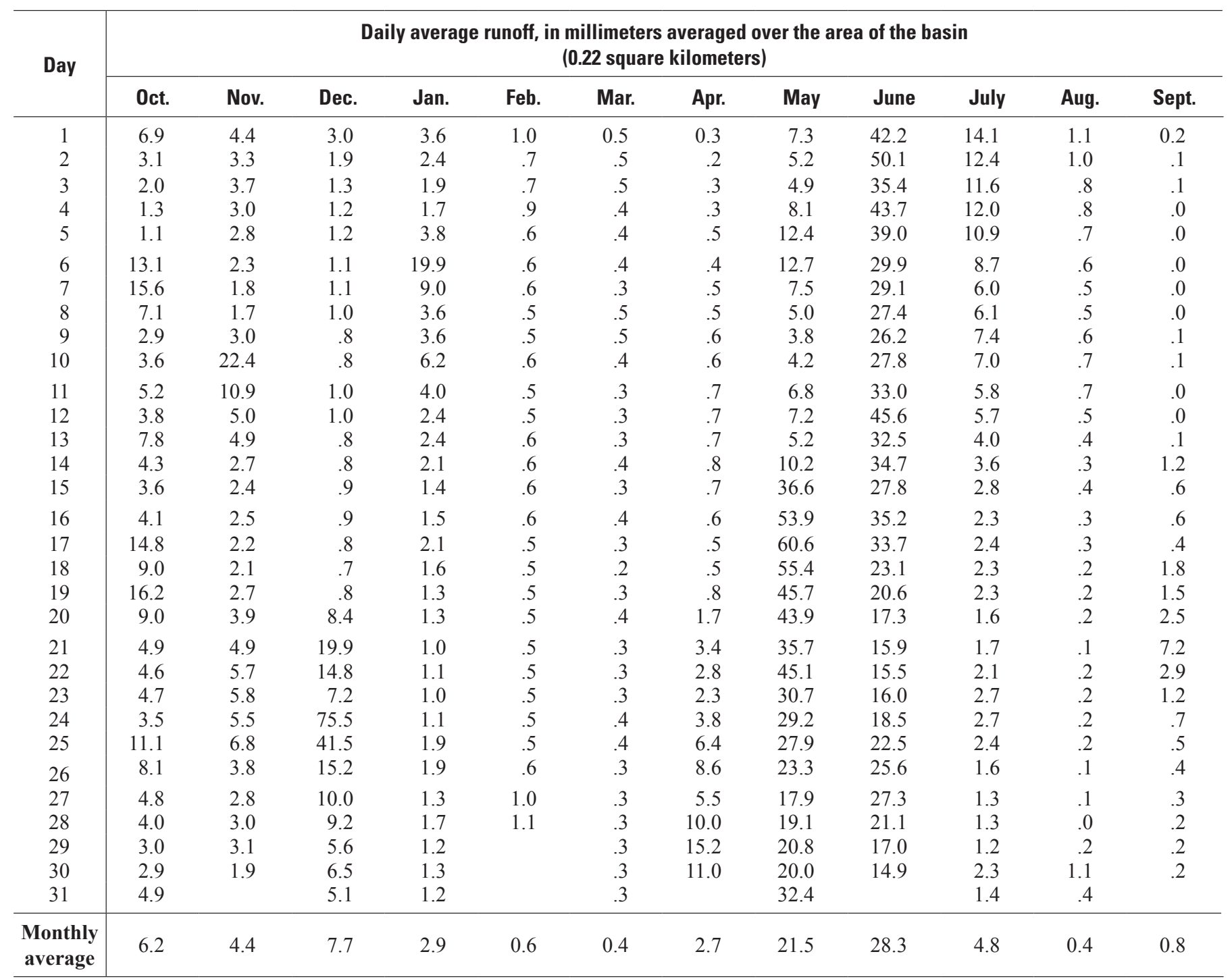


The largest precipitation event measured by the precipitation gage at the Salix Creek gaging station during water year 2007 occurred November 2-7, 2006, during which the gage recorded $343.3 \mathrm{~mm}$ of precipitation (table 21). Air temperature increased from less than to greater than $0^{\circ} \mathrm{C}$ as recorded precipitation began on November 2 and it decreased to less than $0^{\circ} \mathrm{C}$ as gaged precipitation ceased on November 7 , thus the recorded storm total or duration could be in error due to the freezing conditions. The combination of rain and snow melt caused Salix Creek to be at its highest stage of the water year (fig. 11). Large winter snow storms also possibly occurred during the year that were not detected by the unheated precipitation gage. During June through September, when most precipitation likely was rain at the Salix Creek gaging station, total recorded precipitation was $269.0 \mathrm{~mm}$.

Table 21. Daily total precipitation (gage catch) at the Salix Creek gaging station, Salix Creek basin, Washington, 1,587 meters altitude, water year 2007.

\begin{tabular}{|c|c|c|c|c|c|c|c|c|c|c|c|c|}
\hline \multirow{2}{*}{ Day } & \multicolumn{12}{|c|}{ Daily total precipitation, in millimeters } \\
\hline & Oct. & Nov. & Dec. & Jan. & Feb. & Mar. & Apr. & May & June & July & Aug. & Sept. \\
\hline 1 & 0.0 & 0.0 & 0.0 & 18.0 & 0.0 & 0.0 & 0.3 & 4.3 & 0.0 & 0.0 & 0.0 & 0.3 \\
\hline 2 & .0 & 17.3 & .0 & 25.9 & .0 & .0 & 3.3 & 7.1 & .0 & .0 & .0 & .0 \\
\hline 3 & .3 & 62.2 & 6.6 & .0 & .0 & 10.4 & .0 & 1.5 & 2.0 & .0 & .0 & .0 \\
\hline 4 & .0 & 38.1 & .3 & .0 & 4.6 & 1.0 & .8 & .5 & 4.8 & .0 & .0 & 1.0 \\
\hline 5 & .0 & 34.5 & .0 & .0 & .0 & 3.6 & .0 & 1.0 & 13.7 & .0 & .0 & .0 \\
\hline 6 & .0 & 135.1 & 4.1 & .0 & .3 & .0 & .3 & 1.3 & 2.5 & .0 & .0 & .0 \\
\hline 7 & .0 & 56.1 & .0 & .0 & .3 & 5.6 & .0 & .0 & 1.8 & .0 & .5 & .8 \\
\hline 8 & 2.0 & .0 & 1.0 & .0 & 1.0 & .0 & 8.6 & .0 & .3 & .0 & 3.8 & .0 \\
\hline 9 & .0 & .0 & .0 & .0 & .3 & 7.4 & .3 & .0 & 13.2 & .0 & .0 & .0 \\
\hline 10 & .0 & .0 & .3 & .0 & .3 & 18.5 & 5.1 & .0 & 4.3 & .0 & .3 & .0 \\
\hline 11 & .0 & .0 & .0 & .0 & 5.1 & 31.2 & .5 & .0 & 1.8 & .0 & .0 & .0 \\
\hline 12 & .0 & .0 & .0 & .0 & 2.3 & 5.8 & .0 & 4.6 & 1.3 & .0 & 2.0 & .0 \\
\hline 13 & .0 & .0 & .3 & .0 & 1.3 & .5 & 15.5 & 9.9 & 6.1 & 2.5 & .0 & .0 \\
\hline 14 & 1.8 & .0 & .0 & .0 & 1.8 & .0 & 1.3 & .0 & .8 & .0 & .0 & .0 \\
\hline 15 & 10.9 & 54.9 & .0 & .0 & 21.1 & 1.0 & 5.1 & .0 & 3.8 & .0 & .0 & .0 \\
\hline 16 & 6.6 & .0 & .0 & .0 & 3.8 & 23.6 & 1.0 & .0 & 18.3 & .0 & .0 & 6.1 \\
\hline 17 & .0 & 1.3 & .0 & .0 & 7.1 & 15.0 & 2.0 & .0 & 10.4 & .0 & .0 & 6.6 \\
\hline 18 & 6.1 & .0 & .0 & .0 & .0 & 1.3 & 1.8 & .8 & .3 & 9.1 & .3 & 4.1 \\
\hline 19 & 7.4 & 12.4 & 6.9 & .0 & .0 & 3.8 & 2.3 & .5 & .0 & 2.8 & 14.0 & .3 \\
\hline 20 & .3 & .0 & 2.5 & .0 & .0 & .0 & .5 & 2.8 & .0 & 9.9 & 6.4 & 1.0 \\
\hline 21 & .0 & .0 & 1.3 & .0 & .0 & 6.6 & .8 & 13.5 & .0 & 6.6 & 4.6 & 4.1 \\
\hline 22 & .0 & .0 & .0 & .0 & .5 & 3.0 & 2.8 & .3 & 5.1 & 5.3 & .0 & 4.6 \\
\hline 23 & .0 & .0 & .0 & 22.1 & .0 & 27.9 & .0 & .0 & 1.5 & .5 & .0 & .0 \\
\hline 24 & .0 & .0 & .0 & .0 & .0 & 50.0 & 2.0 & .0 & 1.8 & 1.5 & .0 & .0 \\
\hline 25 & .0 & .0 & .0 & .0 & .5 & .3 & .3 & .0 & 3.8 & .0 & 11.2 & .8 \\
\hline 26 & 11.4 & .0 & .0 & .0 & .0 & .5 & 5.6 & .0 & .0 & .0 & 5.8 & .0 \\
\hline 27 & 4.3 & .0 & .0 & .0 & .0 & 1.8 & 28.4 & 5.3 & .0 & .0 & .0 & 14.7 \\
\hline 28 & .0 & .0 & .0 & .0 & .0 & 2.0 & 6.4 & 2.0 & 3.6 & .0 & .0 & 6.4 \\
\hline 29 & 1.5 & .0 & .0 & .0 & & .0 & .0 & .0 & 7.4 & .0 & .0 & 4.8 \\
\hline 30 & 1.5 & .0 & .0 & .0 & & .0 & .0 & .0 & .5 & .0 & .0 & 15.2 \\
\hline 31 & .0 & & .3 & .0 & & 3.0 & & .0 & & .0 & 2.0 & \\
\hline $\begin{array}{l}\text { Monthly } \\
\text { average }\end{array}$ & 54.1 & 411.9 & 23.6 & 66.0 & 50.3 & 223.8 & 95.0 & 55.4 & 109.1 & 38.2 & 50.9 & 70.8 \\
\hline
\end{tabular}



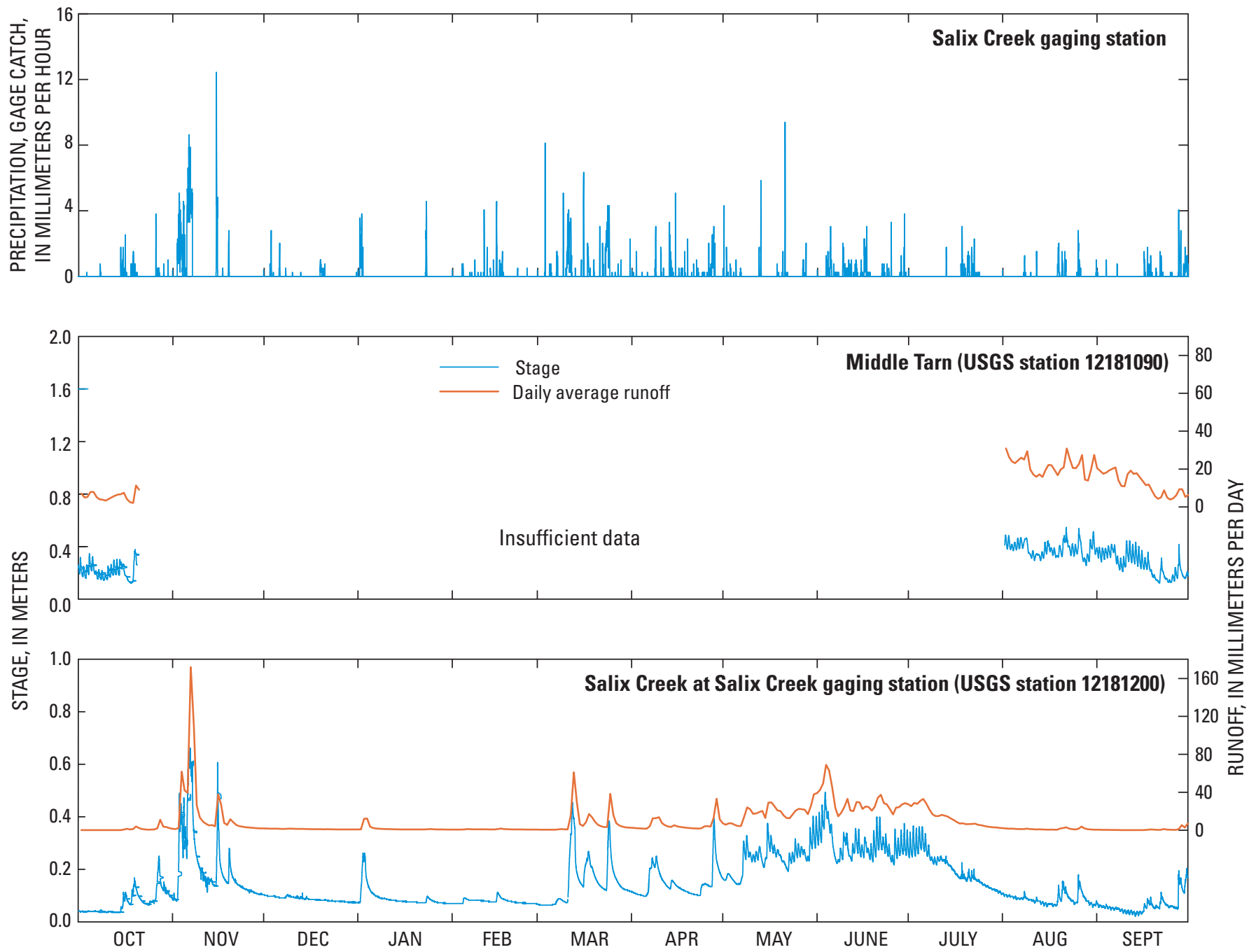

Figure 11. Hourly precipitation (gage catch) at the Salix Creek gaging station, stage of Middle Tarn and Salix Creek, and daily average runoff from Middle Tarn and Salix Creek basins, Washington, water year 2007. Stage was recorded every 15 minutes. Daily summaries of precipitation and runoff are presented in tables $21-23$. 
Gaged daily average runoff from Middle Tarn basin ranged from 2.1 to $30.9 \mathrm{~mm} / \mathrm{d}$ during the months data were available (table 22). The ratio of monthly basin runoff to precipitation recorded at the Salix Creek gaging station decreased from about 13-to-1 for August to about 5-to-1 for September (fig. 10). August and September runoff totaled $1,036 \mathrm{~mm}$, which was about 8.5 times as much as contemporaneous precipitation recorded at the Salix Creek gaging station.

A complete record of runoff from the Salix Creek basin is available for water year 2007. Daily average runoff ranged from $0.1 \mathrm{~mm} / \mathrm{d}$ in October and September to $171.9 \mathrm{~mm} / \mathrm{d}$
November 6 (table 23). Monthly average runoff ranged from $0.9 \mathrm{~mm} / \mathrm{d}$ in February and September to $29.9 \mathrm{~mm} / \mathrm{d}$ in June. Total runoff for the water year was $3,170 \mathrm{~mm}$, which was 27 percent greater than water year 2006 runoff. The ratio of monthly Middle Tarn basin runoff to precipitation recorded at the Salix Creek gaging station increased from about 8-to-1 for June, to about 10-to- 1 for July and then decreased to less than 1-to-1 for August and September (fig. 10). Total runoff during June through September was 1,361 mm, which was about five times as much as contemporaneous precipitation recorded at the Salix Creek gaging station and 31 percent more than Junethrough-September runoff during water year 2006.

Table 22. Daily average runoff from Middle Tarn basin, Washington, October, August, and September, water year 2007.

[Abbreviations:-, insufficient data]

\begin{tabular}{|c|c|c|c|}
\hline \multirow{3}{*}{ Day } & \multicolumn{3}{|c|}{$\begin{array}{l}\text { Daily average runoff, in millimeters } \\
\text { averaged over the area of the basin } \\
\text { ( } 4.46 \text { square kilometers) }\end{array}$} \\
\hline & \multirow{2}{*}{2006} & \multicolumn{2}{|c|}{2007} \\
\hline & & August & September \\
\hline 1 & 7.1 & 30.9 & 19.0 \\
\hline 2 & 5.0 & 26.4 & 17.5 \\
\hline 3 & 5.2 & 24.0 & 18.2 \\
\hline 4 & 7.9 & 23.1 & 19.3 \\
\hline 5 & 7.9 & 24.6 & 20.1 \\
\hline 6 & 5.2 & 26.0 & 20.9 \\
\hline 7 & 4.0 & 25.0 & 13.9 \\
\hline 8 & 3.8 & 29.4 & 11.0 \\
\hline 9 & 3.3 & 19.7 & 10.9 \\
\hline 10 & 4.2 & 17.1 & 17.3 \\
\hline 11 & 5.1 & 15.9 & 19.2 \\
\hline 12 & 5.9 & 17.2 & 17.4 \\
\hline 13 & 6.5 & 15.8 & 17.8 \\
\hline 14 & 6.7 & 19.5 & 15.7 \\
\hline 15 & 7.5 & 22.2 & 13.5 \\
\hline 16 & 4.1 & 22.0 & 11.5 \\
\hline 17 & 2.5 & 19.4 & 11.9 \\
\hline 18 & 2.1 & 16.7 & 8.6 \\
\hline 19 & 11.3 & 19.8 & 5.7 \\
\hline 20 & - & 20.8 & 4.3 \\
\hline 21 & - & 30.9 & 5.0 \\
\hline 22 & - & 25.1 & 8.8 \\
\hline 23 & - & 20.6 & 4.9 \\
\hline 24 & - & 20.4 & 3.9 \\
\hline 25 & - & 22.7 & 4.5 \\
\hline 26 & - & 27.4 & 6.2 \\
\hline 27 & - & 14.4 & 9.4 \\
\hline 28 & - & 13.9 & 9.3 \\
\hline 29 & - & 19.9 & 5.3 \\
\hline 30 & - & 27.5 & 6.3 \\
\hline 31 & - & 20.4 & \\
\hline $\begin{array}{c}\text { Monthly } \\
\text { average }\end{array}$ & - & 21.9 & 11.9 \\
\hline
\end{tabular}


Table 23. Daily average runoff from Salix Creek basin at the Salix Creek gaging station, Washington, water year 2007.

\begin{tabular}{|c|c|c|c|c|c|c|c|c|c|c|c|c|}
\hline \multirow{2}{*}{ Day } & \multicolumn{12}{|c|}{$\begin{array}{l}\text { Daily average runoff, in millimeters averaged over the area of the basin } \\
\qquad(0.22 \text { square kilometers) }\end{array}$} \\
\hline & Oct. & Nov. & Dec. & Jan. & Feb. & Mar. & Apr. & May & June & July & Aug. & Sept. \\
\hline 2 & .2 & 2.4 & 1.6 & 12.0 & .7 & .5 & 2.1 & 7.3 & 49.5 & 28.8 & 1.7 & .4 \\
\hline 3 & .2 & 61.8 & 1.6 & 12.3 & .7 & .5 & 1.9 & 7.2 & 68.9 & 27.8 & 1.6 & .4 \\
\hline 4 & .2 & 42.0 & 1.6 & 3.8 & .9 & .5 & 1.7 & 5.6 & 62.9 & 31.2 & 1.5 & .4 \\
\hline 6 & .2 & 171.9 & 1.4 & 1.8 & 1.1 & .6 & 4.3 & 4.5 & 23.6 & 28.0 & 1.3 & .3 \\
\hline 7 & .1 & 109.9 & 1.4 & 1.5 & 1.0 & 1.0 & 12.6 & 13.9 & 14.7 & 21.7 & 1.3 & .3 \\
\hline 8 & .2 & 26.0 & 1.6 & 1.4 & 1.0 & 1.2 & 12.8 & 24.1 & 18.5 & 16.7 & 1.6 & .2 \\
\hline 9 & .1 & 13.5 & 1.6 & 1.3 & 1.0 & 1.0 & 13.7 & 22.0 & 24.6 & 14.9 & 1.2 & .2 \\
\hline 10 & .1 & 9.2 & 1.5 & 1.2 & 1.0 & .8 & 7.5 & 17.3 & 33.1 & 14.9 & 1.1 & .1 \\
\hline 11 & .1 & 6.8 & 1.4 & 1.1 & 1.0 & 15.4 & 5.3 & 17.7 & 20.8 & 16.2 & .9 & .1 \\
\hline 16 & 1.5 & 27.2 & 1.1 & .9 & 1.8 & 8.5 & 3.5 & 29.4 & 25.1 & 8.6 & .7 & .3 \\
\hline 17 & .8 & 7.8 & 1.1 & .9 & 1.3 & 17.2 & 3.0 & 25.2 & 24.4 & 7.0 & .6 & .6 \\
\hline 18 & 1.3 & 5.5 & 1.1 & .9 & 1.1 & 13.7 & 2.6 & 20.9 & 20.7 & 7.3 & .6 & .8 \\
\hline 19 & 4.0 & 11.6 & 1.1 & .9 & 1.0 & 8.9 & 2.4 & 20.2 & 24.8 & 6.4 & 1.8 & .5 \\
\hline 20 & 2.2 & 8.5 & 1.0 & .8 & .9 & 5.6 & 2.1 & 15.6 & 34.1 & 6.5 & 2.3 & .4 \\
\hline 21 & 1.2 & 5.5 & 1.1 & .8 & .8 & 4.1 & 2.0 & 12.9 & 37.4 & 6.7 & 3.1 & .4 \\
\hline 22 & .8 & 4.3 & 1.0 & .8 & .8 & 3.3 & 1.8 & 12.6 & 28.5 & 6.9 & 1.7 & 1.3 \\
\hline 23 & .6 & 3.7 & 1.0 & 1.1 & .8 & 3.4 & 2.1 & 16.8 & 27.3 & 5.7 & 1.1 & .7 \\
\hline 24 & .7 & 3.2 & .9 & 1.3 & .7 & 38.3 & 4.2 & 20.8 & 22.1 & 5.2 & .8 & .5 \\
\hline 25 & .9 & 2.9 & .9 & 1.0 & .7 & 15.9 & 4.3 & 22.6 & 16.6 & 4.4 & 1.5 & .4 \\
\hline 26 & 2.1 & 2.7 & .9 & .9 & .7 & 7.4 & 3.9 & 22.1 & 24.0 & 3.9 & 3.9 & .4 \\
\hline
\end{tabular}




\section{Analysis of Glacier Air Temperature at 2-Meter Height}

To support development of the previously described mass balance model, glacier air-temperature data collected at selected mass balance sites during 2006 and 2007 were analyzed in conjunction with similar data collected during 2003 to 2005 (Bidlake and others 2005, 2007). The analysis was intended to develop techniques for estimating air temperature at mass balance sites for periods when it was not measured. The temperature sensors had been moved among several different mass balance sites during the years, such that 2-m-height air temperature had been measured during at least one summer at each site except S1740. Previously collected air temperature data indicated daily average air temperature at a height of $2 \mathrm{~m}$ rarely varied with altitude among the sites according to a constant temperature lapse rate (hereafter, lapse rate).

The lapse rate in the atmosphere refers to temperature change with respect to altitude and is defined by $(-d T / d Z)$, where $T$ is temperature and $Z$ is altitude (Wallace and Hobbs, 1977). A theoretical, completely dry parcel of air that exchanges no heat with its surroundings, if it were to rise in the atmosphere, would cool at the dry, adiabatic lapse rate of about 9.8 degrees Celsius per kilometer of altitude increase $\left({ }^{\circ} \mathrm{C} / \mathrm{km}\right)$ in response to decreasing atmospheric pressure (Wallace and Hobbs, 1977). The quantity of air is termed a parcel because mass air movement in the turbulent lower atmosphere is dominated by movement of well-defined, variously sized air masses. Adiabatic refers to the lack of heat exchange between the parcel and its environment. Experimentally measured lapse rates typically differ from the dry, adiabatic lapse rate because the atmosphere contains moisture and because all air parcels exchange at least some heat with their environment. The presence of water vapor, if it saturates the parcel air upon cooling and begins to condense, decreases the lapse rate. Heat exchange between the parcel and its environment can either increase or decrease the observed lapse rate, depending on whether rising or sinking air parcels are losing or gaining heat. Wallace and Hobbs (1977) indicate that lapse rates are highly variable, they average about $7^{\circ} \mathrm{C} / \mathrm{km}$ in the lowest $10 \mathrm{~km}$ of the atmosphere, and they never exceed $10^{\circ} \mathrm{C} / \mathrm{km}$, except near the ground.

A warm air mass passing over a melting glacier surface loses heat to the glacier and the heat loss causes the air to cool. This glacier cooling effect (Braithwaite, 2008) can cause air near the surface to be cooler than air at the same altitude that is away from the influence of the glacier. The uninfluenced air is called the free atmosphere in this report and in some glaciological literature (Greuell and Böhm, 1998; Braithwaite, 2008). Surface temperature of a melting glacier remains close to the melting point of ice and is coupled to the temperature of the free atmosphere through a near-surface boundary layer where temperatures are intermediate between those of the glacier surface and the free atmosphere. For this reason, air near the glacier surface tends to be cooler than air immediately above the surface but outside of the boundary layer.

For this report, an empirical approach was used to estimate 2-m-height air temperature at the glacier mass balance sites from air temperature at a reference site. The equation used for 2-m-height air temperature was

where

$$
T_{2}=T_{e}(Z)-\delta T_{q},
$$

$T_{2}$ is daily average air temperature at $2-\mathrm{m}$ height at a given mass balance site, in degrees Celsius;

$T_{e}(Z)$ is daily average temperature of the free atmosphere at the altitude of the mass balance site, in degrees Celsius; and

$\delta T_{q}$ is the difference between $T_{2}$ and $T_{e}(Z)$ due to the glacier cooling effect, in degrees Celsius.

The right-hand side of equation 15 thus contains a component for temperature that results from the nearly adiabatic processes of the lower atmosphere away from the ground or the glacier, $T_{e}(Z)$, and a term that accounts for the glacier cooling effect, $\delta T_{q}$, that results from heat loss to the glacier. The equation for $T_{e}(Z)$ was

$$
T_{e}(Z)=T_{r}+\Gamma\left(Z_{r}-Z\right) / 1,000
$$

where

$T_{r}$ is reference daily average air temperature, in degrees Celsius;

$\Gamma$ is temperature lapse rate in the atmosphere, in degrees Celsius per kilometer;

$Z_{r}$ is altitude of the temperature reference site, in meters; and

$Z$ is as defined previously.

Equation 16 shows that specifying $T_{r}$ and $\Gamma$ is equivalent to specifying the air-temperature profile in the free atmosphere. The reference air temperature used for this report was daily average temperature at the Hut, which was almost complete for 2003 to 2007. Location of the Hut air temperature sensor over the roof of that structure likely caused some "contamination" of the air-temperature data due to the influence of the structure and ground nearby. Temperature over the Hut roof was considered to be more consistent with the free atmosphere temperature profile than other measurement sites within the basin, however, because the Hut itself was on a narrow, exposed ridge top and thus was more aerodynamically isolated from the glacier and other surfaces than other temperature-measurement sites in or near South Cascade Lake basin. 
An estimate of the average lapse rate of daily average temperature was computed using a subset of the 2003-07 glacier air-temperature records. The subset included data only for cool days when daily average air temperature at 2-m height over the glacier was within $1^{\circ} \mathrm{C}$ of the glacier surface temperature. The air-temperature subset was assumed to represent conditions when temperature gradients within the boundary layer and the glacier cooling effect were negligible. During summer, energy absorbed by melting snow and ice and released by refreezing of melt water during cold nights and weather spells probably kept the glacier surface temperature close to the ice melting point. Glacier surface temperature, therefore, was assumed to equal $0^{\circ} \mathrm{C}$ during the primarily summer months when glacier air temperature was measured.

The lapse rate was equal to the slope of the best-fitted line to a plot of the air-temperature and altitude differences between the reference site and selected mass balance sites (fig. 12). The slope was $7.35^{\circ} \mathrm{C} / \mathrm{km}$ (coefficient of determination $\left[\mathrm{r}^{2}\right]$ 0.84, sample size 209). This experimental value for $\Gamma$ was numerically close to the average of the highly variable lapse rates of the lower atmosphere $\left(7^{\circ} \mathrm{C} / \mathrm{km}\right)$ indicated by Wallace and Hobbs (1977).

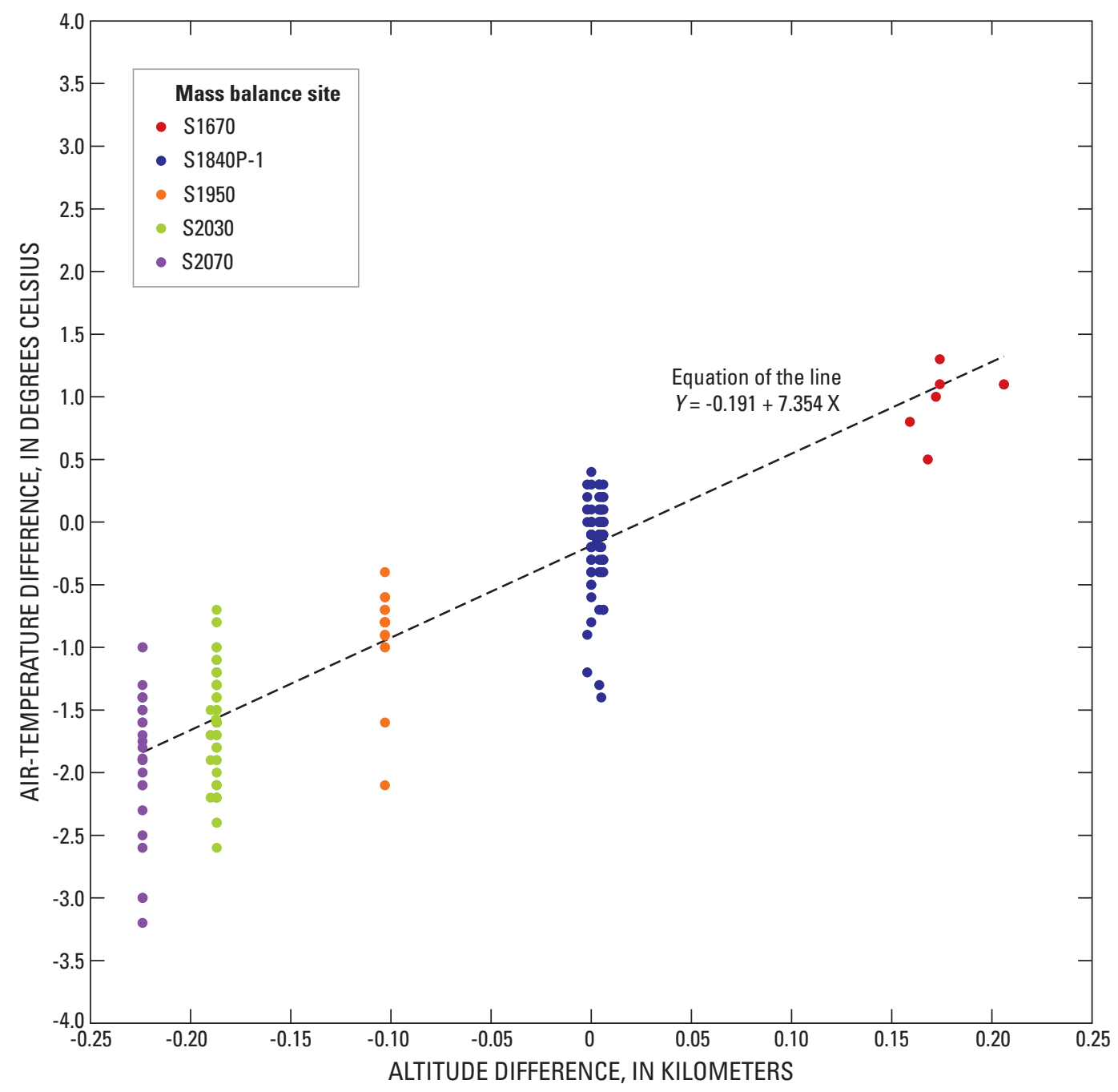

Figure 12. Air-temperature difference between the temperature reference at the Hut and at 2-meters-height at selected mass balance sites on South Cascade Glacier, Washington, as it varied with Hut-to-site altitude difference, during parts of April-0ctober, water years 2003-07. Data are included only for days when average site-measured air temperature was within the range $-1^{\circ} \mathrm{C}$ to $1^{\circ} \mathrm{C}$. Locations of mass balance sites are shown in figure 2 . 
The glacier cooling effect began to operate when air masses over South Cascade Lake basin were warmer than the glacier. Air temperature at 2-m-height over the glacier became progressively less than $T_{e}(Z)$ as the latter increased (fig. 13). The glacier cooling effect was most pronounced at mass balance site S1840P-1 and least pronounced at site S2070. Variations among the sites in the strength of the glacier cooling effect likely were caused by variations of aerodynamic conditions that influenced thickness of and conditions in the near-surface boundary layer and its resistance to turbulent transfer of sensible heat between the glacier surface and the free atmosphere. Included among relevant aerodynamic conditions were wind speed, surface aerodynamic roughness and slope, and fetch (the distance the wind traveled over the glacier before reaching a particular site). Detailed analyses of these aerodynamic conditions were not within the scope of this report, which was the reason the empirical approach was used to estimate air temperature over the glacier.

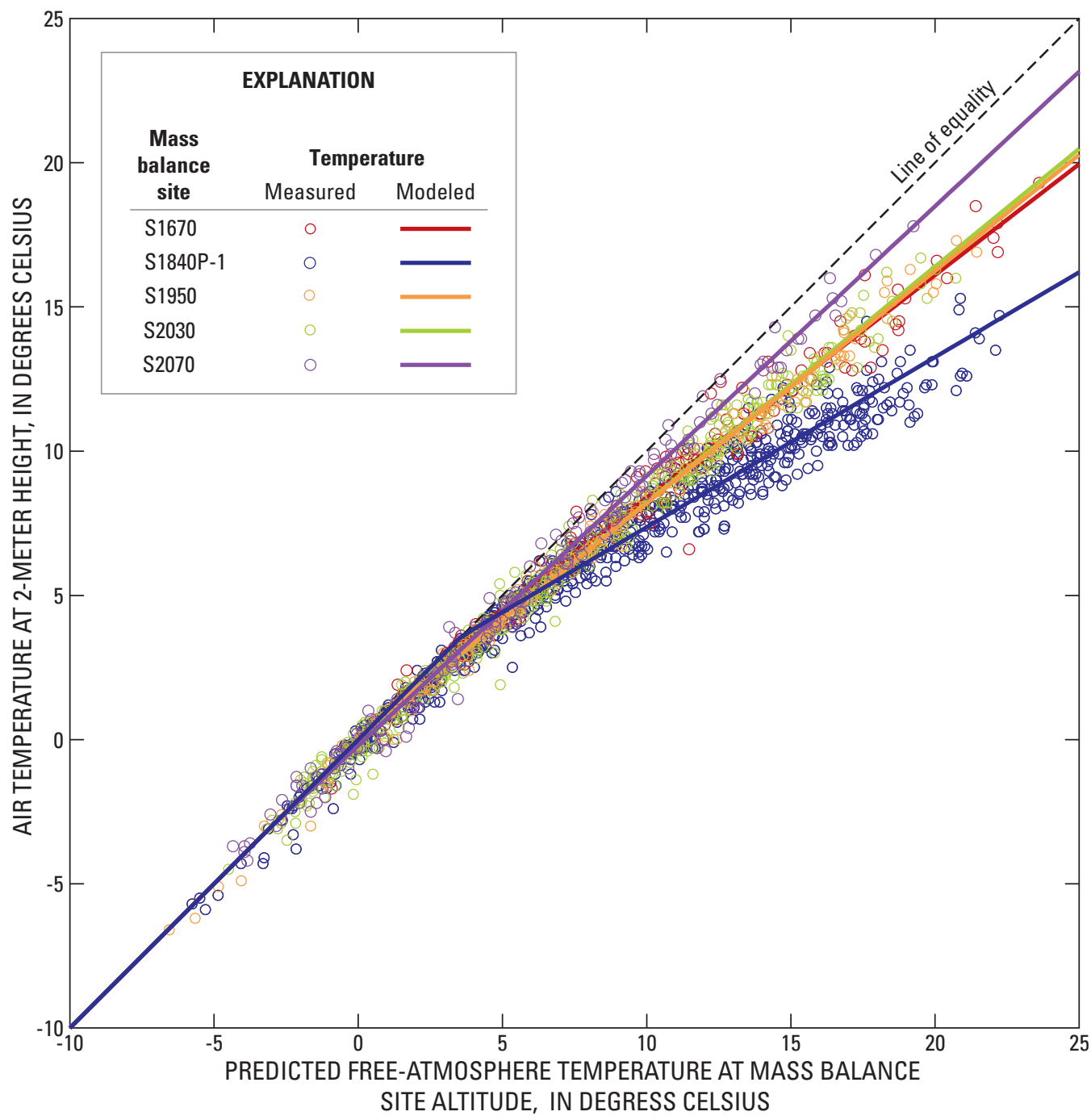

Figure 13. Measured and modeled daily average air temperature at 2-meters-height at selected mass balance sites on South Cascade Glacier, Washington, as they varied with freeatmosphere temperature predicted from temperature at a reference site, the altitude difference between the reference and mass balance sites, and using a constant temperature lapse rate (7.35 degrees Celsius per kilometer), during parts of April-0ctober, water years 2003-2007. Locations of mass balance sites are shown in figure 2. 
The term in equation 15 for the glacier cooling effect on air temperature at 2-m height, $\delta T_{q}$, was computed with the empirically based, piecewise linear function:

$$
\delta T_{q}=0 \quad\left(T_{e}(Z) \text { less than or equal to } d_{0}\right)
$$

$$
\delta T_{q}=\left(T_{e}(Z)-d_{0}\right) \times d_{1} \quad\left(T_{e}(Z) \text { greater than } d_{0}\right),
$$

where

$d_{0}$ and $d_{1}$ are empirical coefficients; and

Other terms are as defined previously.

Cold air masses in which temperature at a given altitude approaches that of the glacier surface lose little or no heat to the glacier, in which case the term for $\delta T_{q}$ tends toward 0 . The empirically determined coefficient $d_{0}$ is the critical temperature at and below which $\delta T_{q}$ equals 0 . If free-atmosphere temperature is greater than the critical temperature, $\delta T_{q}$ is proportional to the difference between the free-atmosphere and critical temperatures and the proportionality constant is $d_{1}$.

The coefficients $d_{0}$ and $d_{1}$ were computed for each of the five mass balance sites where air temperature at 2-m height was measured during 2003-07 (ig. 13). First, equations 16-18 were substituted for $T_{e}(Z)$ and $\delta T_{q}$ in equation 15 . Equation 15 was then evaluated using the previously discussed lapse rate of $7.35^{\circ} \mathrm{C} / \mathrm{km}$, air temperature and altitude at the Hut, altitude at a given mass balance site, and initial values of 0 for $d_{0}$ and $d_{1}$. The coefficients $d_{0}$ and $d_{1}$ were then adjusted for each site to minimize the RMSE in predicted daily average air temperature (table 24). The overall RMSE and sample size were $0.60^{\circ} \mathrm{C}$ and 2,166, respectively.

Although the experimental lapse rate and the predictive equations for 2-m-height air temperature were developed from mostly summer data, they likely were suitable for mass balance modeling year-around. All of the data sets used included temperatures that spanned the threshold temperatures for precipitation to fall as snow $\left(2^{\circ} \mathrm{C}\right)$ and for the onset of melt $\left(0^{\circ} \mathrm{C}\right)$ that were used in the mass balance model.
Table 24. Coefficients for equations for estimating effect of South Cascade Glacier, Washington, on air temperature at a height of 2 meters above the glacier surface at five mass balance sites.

[Site locations are shown in figure 2. Abbreviations: RMSE, root-meansquare error, in degrees Celsius]

\begin{tabular}{lcrrrr}
\hline \multirow{2}{*}{$\begin{array}{c}\text { Mass } \\
\text { balance } \\
\text { site }\end{array}$} & $\begin{array}{c}\text { Average } \\
\text { site altitude } \\
\text { (meters) }\end{array}$ & \multicolumn{2}{c}{ Model coefficients } & & d \\
\cline { 3 - 4 } RMSE & $\mathbf{d}_{\mathbf{1}}$ & & $\begin{array}{c}\text { Sample } \\
\text { size }\end{array}$ \\
\hline S1670 & 1,666 & 2.941 & 0.229 & 0.630 & 659 \\
S1840P-1 & 1,840 & 3.583 & .410 & .654 & 782 \\
S1950 & 1,945 & .706 & .194 & .442 & 152 \\
S2030 & 2,030 & .297 & .183 & .525 & 418 \\
S2070 & 2,066 & -3.156 & .065 & .507 & 155 \\
\hline
\end{tabular}

The glacier cooling effect dampened day-to-dayvariations of air temperature near the glacier surface as compared with variations at the off-glacier reference site, as was apparent in the ratio of temperature variance at the Hut to that at 2-m height over the glacier. The ratio ranged from 1.14 at site S2070, where the glacier influence was weakest, to 2.11 at site $\mathrm{S} 1840 \mathrm{P}-1$, where the glacier influence was strongest. The ratio of variances ranged from 1.43 to 1.55 at the other mass balance sites, where strength of the glacier influence on air temperature was intermediate between sites S2070 and S1840P-1.

The dampening of air-temperature variations by the glacier was similar to the dampening commonly observed over a lake (Brutsaert, 1982) in that both are caused by the relative stability of surface temperature over time. The surface temperature of South Cascade Glacier was maintained close to $0^{\circ} \mathrm{C}$ during summer months by the energy absorbed by ice and snow melt and released by water re-freezing during cool periods; whereas, the surface temperature of a lake responds slowly to weather changes due to the large heat capacity and internal mixing of the water mass. 


\section{Measured Mass Balances at Selected Sites}

Winter balance glaciological measurements and ablation stake placements at South Cascade Glacier were made during cold, mostly clear weather April 23-26. Snow depth was measured by probing at each mass balance site and at other selected locations on the glacier (fig. 14). Ablation stakes were placed at each mass balance site and snow density was measured at three of those sites. At some sites, snow depth and snow density were measured on a different day than when the ablation stakes were place. In such instances, snow depth and density at the time the stakes were placed were assumed to equal the depth and density on the day they were measured. Snow depth ranged from $2.62 \mathrm{~m}$ at mass balance site S1670, to $5.53 \mathrm{~m}$ at site $\mathrm{S} 1840 \mathrm{P}-1$, to as much as $6.74 \mathrm{~m}$ between sites S2030 and S2070 on the upper glacier (fig. 14). Snow depth data presented in figure 14 also are presented in table 25. Balance year 2005 had ended with ice exposed at most of the 2006 probing sites and the large contrast of probe-penetration resistance between snow and ice caused little ambiguity in detecting the 2005 summer surface beneath the 2006 snow pack in most locations. Independent measures of late-April snow depth were made in a few places to test reliability of probing for snow depth. For example, snow depth at mass balance site S1840P-1 determined by digging and auguring to the ice agreed to within $0.10 \mathrm{~m}$ and 2 percent of the depth determined by probing. The difference could have been caused by the roughness of the glacier surface under the snow pack. Probing for snow depth also was reliable at site S2070 on the upper glacier, where the snow pack rested on ice and where probing indicated snow depth was $5.92 \mathrm{~m}$. The late-April snow depth at the site was recomputed in late summer, after the previous winter's snow had ablated from the site. Total surface lowering during April 24-September 10, 2006, was $6.65 \mathrm{~m}$; some of the lowering was due to ice melt. The thickness of ice lost was $0.77 \mathrm{~m}$ during April 24-September 10, 2006, as was estimated from ice-surface lowering during October 22, 2005, to September 10, 2006 on ablation stake 9-04, about $4 \mathrm{~m}$ from stake 1-06 (Bidlake and others, 2007). Assuming that all the ice ablation after October 22, 2005, occurred during summer 2006, the recomputed, late-April snow depth was $5.88 \mathrm{~m}$, which agreed to within $0.04 \mathrm{~m}$ and 1 percent with the snow depth measured by late-April probing.
Table 25. Snow depth and snow mass balance at selected locations on South Cascade Glacier, Washington, April 2006.

[ $X$ and $Y$ are easting and northing coordinates in a local coordinate system, meters; $Z$, altitude, meters. Entries for mass balance sites are bolded. Abbreviations: SWE, snow water equivalent; m, meter]

\begin{tabular}{|c|c|c|c|c|}
\hline$X$ & $Y$ & $Z$ & $\begin{array}{c}\text { Snow depth } \\
\text { (m) }\end{array}$ & $\begin{array}{c}\text { Snow mass } \\
\text { balance } \\
\text { (mWE) }\end{array}$ \\
\hline \multicolumn{5}{|c|}{ April 23} \\
\hline 1,820 & 2,763 & $\mathbf{1 , 8 3 7}$ & 5.53 & 2.60 \\
\hline 1,838 & 2,695 & 1,842 & 5.62 & 2.64 \\
\hline 1,869 & 2,619 & 1,849 & 5.62 & 2.64 \\
\hline 1,909 & 2,530 & 1,862 & 5.77 & 2.65 \\
\hline 1,935 & 2,454 & 1,880 & 6.59 & 3.03 \\
\hline 1,954 & 2,406 & 1,894 & 5.97 & 2.75 \\
\hline 1,978 & 2,345 & 1,907 & 5.50 & 2.53 \\
\hline 2,019 & 2,266 & 1,918 & 6.22 & 2.80 \\
\hline 2,048 & 2,202 & 1,926 & 5.77 & 2.60 \\
\hline 2,087 & 2,128 & 1,934 & 5.62 & 2.53 \\
\hline 2,113 & 2,062 & 1,941 & 5.67 & 2.55 \\
\hline 2,148 & 1,979 & 1,950 & 5.92 & 2.66 \\
\hline 2,170 & 1,920 & 1,960 & 6.12 & 2.69 \\
\hline 2,212 & 1,852 & 1,980 & 6.32 & 2.78 \\
\hline 2,237 & 1,805 & 1,991 & 6.47 & 2.85 \\
\hline 2,296 & 1,753 & 2,005 & 6.02 & 2.59 \\
\hline 2,341 & 1,706 & 2,013 & 6.12 & 2.63 \\
\hline 2,382 & 1,668 & 2,018 & 6.47 & 2.78 \\
\hline 2,426 & 1,563 & 2,028 & 6.42 & 2.76 \\
\hline \multicolumn{5}{|c|}{ April 24} \\
\hline 2,147 & 2,017 & 1,945 & 5.50 & 2.48 \\
\hline 2,509 & 1,599 & 2,032 & 6.74 & 2.90 \\
\hline 2,578 & 1,626 & 2,039 & 6.54 & 2.81 \\
\hline 2,662 & 1,655 & 2,047 & 6.12 & 2.63 \\
\hline 2,732 & 1,683 & 2,052 & 5.97 & 2.57 \\
\hline 2,809 & 1,714 & 2,059 & 5.72 & 2.46 \\
\hline 2,852 & 1,688 & 2,066 & 5.92 & 2.55 \\
\hline \multicolumn{5}{|c|}{ April 25} \\
\hline 1,698 & 3,450 & 1,674 & 2.62 & 1.02 \\
\hline 1,697 & 3,406 & 1,687 & 3.59 & 1.44 \\
\hline 1,681 & 3,378 & 1,697 & 4.07 & 1.63 \\
\hline 1,658 & 3,353 & 1,705 & 4.12 & 1.69 \\
\hline 1,650 & 3,308 & 1,719 & 3.59 & 1.47 \\
\hline 1,632 & 3,254 & 1,736 & 5.11 & 2.15 \\
\hline 1,606 & 3,209 & 1,752 & 4.70 & 2.02 \\
\hline 1,569 & 3,177 & 1,764 & 4.57 & 1.97 \\
\hline 1,573 & 3,119 & 1,786 & 4.37 & 1.92 \\
\hline 1,560 & 3,072 & 1,799 & 4.37 & 1.97 \\
\hline 1,641 & 3,019 & 1,809 & 4.90 & 2.25 \\
\hline 1,681 & 2,957 & 1,820 & 5.25 & 2.42 \\
\hline 1,727 & 2,885 & 1,829 & 5.35 & 2.51 \\
\hline 1,769 & 2,833 & 1,833 & 5.50 & 2.59 \\
\hline
\end{tabular}




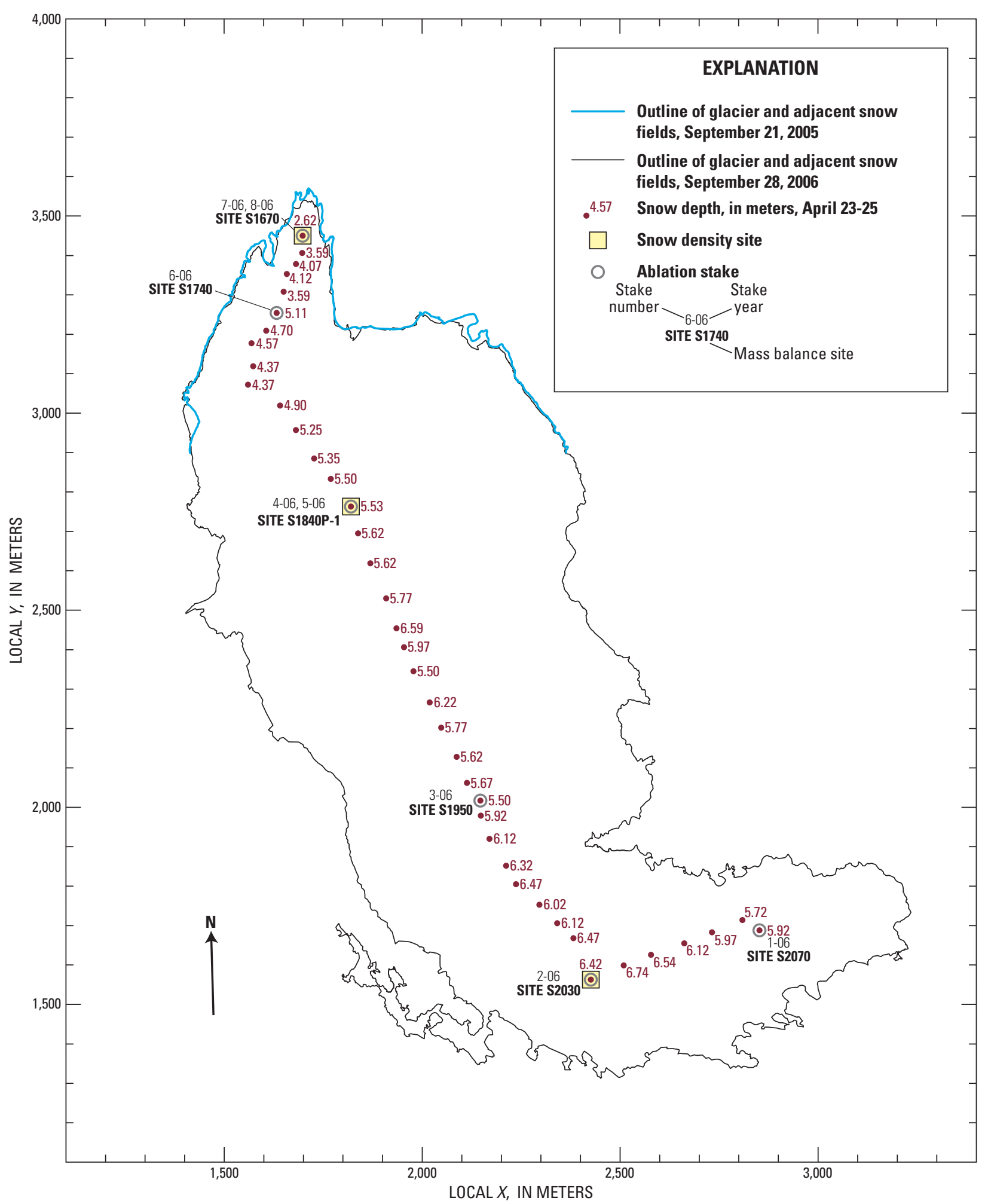

Figure 14. Partial and complete outlines of South Cascade Glacier, Washington, 2005 and 2006, and locations of 2006 measurement sites for snow depth and density and ablation stakes. Snow depth, in meters, is presented next to the measurement site and also in table 25 . 
Probing was thought less reliable at mass balance site S2030, where the snow pack lay atop old firn that formed the 2005 summer surface. Late-April probing yielded a snow depth of $6.84 \mathrm{~m}$. A layer of increased resistance to probe penetration starting at a depth of $6.12 \mathrm{~m}$ was noted at the time, but it was assumed the layer was consolidated snow of the 2006 snow pack. Auguring and measuring the thickness of residual snow atop the old firn on September 24 and adding the residual snow thickness $(0.31 \mathrm{~m})$ to surface lowering since late April $(6.11 \mathrm{~m})$ yielded a late-April snow depth of $6.42 \mathrm{~m}$. The recomputed snow depth was $0.42 \mathrm{~m}$ or 6 percent less than the probed snow depth and the discrepancy was greater than could be explained by surface roughness. The late-April probing probably failed to detect the interface between snow and the old firn.

Density of the late-April snow pack on South Cascade Glacier was measured through the entire snow thickness at mass balance sites S1670 and S1840P-1 and was measured through part of the snow thickness at site S2030 (fig. 14). Density at site S1670 was measured from the surface using the specially designed snow corer described previously. Average density of the entire snow thickness was 0.39 (table 26). Average density of the entire snow thickness at site S1840P-1, measured using a combination of samples taken from the wall of a pit and samples extracted with the coring auger, was 0.47 (table 27). Average snow density at site S2030 to a depth of $4.57 \mathrm{~m}$, where the corer stopped penetrating, was 0.39 (table 28). The density of the remaining thickness was estimated to equal 0.52 , which was the snow density below a depth of $4.55 \mathrm{~m}$ at site S1840P-1. The average snow density at site $\mathrm{S} 2030$ was computed to be 0.43 .

The snow mass balance ranged from $1.02 \mathrm{mWE}$ at site $\mathrm{S} 1670,1,674 \mathrm{~m}$ altitude, to $2.60 \mathrm{mWE}$ at site $\mathrm{S} 1840 \mathrm{P}-1$, $1,837 \mathrm{~m}$ altitude, to $3.03 \mathrm{mWE}$ at approximately mid-glacier, $1,880 \mathrm{~m}$ altitude (table 25). The snow mass balance on the upper one-half of the glacier ranged from 2.46 to $2.90 \mathrm{mWE}$.

Table 26. Snow density profile measured at mass balance site S1670 near the terminus of South Cascade Glacier, Washington, April 25, 2006.

[Snow density was computed from 60.0-millimeter-diameter samples taken with a snow corer. Location $X=1,698, Y=3,450$, where $X$ and $Y$ are easting and northing coordinates in a local coordinate system, meters; 1,674 meters altitude]

\begin{tabular}{cccc}
\hline & Snow sample & & Sample density \\
(fraction of \\
$\begin{array}{c}\text { Bottom } \\
\text { (meters) }\end{array}$ & $\begin{array}{c}\text { Length } \\
\text { (meters) }\end{array}$ & $\begin{array}{c}\text { Mass } \\
\text { (kilograms) }\end{array}$ & water density) \\
\hline 1.13 & 1.13 & 1.155 & 0.36 \\
2.51 & 1.34 & 1.600 & .42 \\
2.63 & .11 & .135 & .43 \\
\hline
\end{tabular}

The 2006 winter snow pack had almost completely melted from the glacier by early September. A series of September snows intermittently covered the glacier and part of the upper glacier was thinly covered when aerial photographs were taken on September 28, 2006 (fig. 15). On October 20, no residual snow from the previous winter was present at any ablation stakes, but new snow covered the glacier as low as mass balance site S1950, altitude 1,945 m (table 29).

Table 27. Snow density profile measured at mass balance site S1840P-1 on South Cascade Glacier, Washington, April 25-26, 2006.

[Snow density to a depth of 1.42 meters was computed from 72.3-millimeterdiameter samples taken with a sampling tube from the wall of a pit. Snow density between depths of 1.42 and 5.48 meters was computed from 76.3-millimeter-diameter samples taken with a coring auger. Location $X=$ $1,820, Y=2,763$, where $X$ and $Y$ are easting and northing coordinates in a local coordinate system, meters; 1,837 meters altitude]

\begin{tabular}{|c|c|c|c|}
\hline \multicolumn{3}{|c|}{ Snow sample } & \multirow{2}{*}{$\begin{array}{l}\text { Sample density } \\
\text { (fraction of } \\
\text { water density) }\end{array}$} \\
\hline $\begin{array}{l}\text { Bottom } \\
\text { (meters) }\end{array}$ & $\begin{array}{l}\text { Length } \\
\text { (meters) }\end{array}$ & $\begin{array}{c}\text { Mass } \\
\text { (kilograms) }\end{array}$ & \\
\hline 0.40 & 0.40 & 0.636 & 0.39 \\
\hline .84 & .44 & .752 & .42 \\
\hline 1.35 & .51 & .810 & .39 \\
\hline 1.42 & .08 & .175 & .57 \\
\hline 2.20 & .80 & 1.635 & .45 \\
\hline 2.70 & .48 & 1.020 & .46 \\
\hline 3.12 & .46 & 1.040 & .49 \\
\hline 3.49 & .38 & .870 & .50 \\
\hline 4.04 & .57 & 1.300 & .50 \\
\hline 4.55 & .49 & 1.160 & .52 \\
\hline 5.03 & .46 & 1.060 & .50 \\
\hline 5.48 & .35 & .860 & .54 \\
\hline
\end{tabular}

Table 28. Partial snow density profile at mass balance site $\mathrm{S} 2030$ on upper South Cascade Glacier, Washington, April 24, 2006.

[Snow density was computed from 60.0-millimeter-diameter samples taken with a snow corer. Location $\boldsymbol{X}=2,147, \boldsymbol{Y}=2,017$, where $\boldsymbol{X}$ and $\boldsymbol{Y}$ are easting and northing coordinates in a local coordinate system, meters; 2,028 meters altitude]

\begin{tabular}{|c|c|c|c|}
\hline \multicolumn{3}{|c|}{ Snow sample } & \multirow{2}{*}{$\begin{array}{l}\text { Sample density } \\
\text { (fraction of } \\
\text { water density) }\end{array}$} \\
\hline $\begin{array}{l}\text { Bottom } \\
\text { (meters) }\end{array}$ & $\begin{array}{l}\text { Length } \\
\text { (meters) }\end{array}$ & $\begin{array}{c}\text { Mass } \\
\text { (kilograms) }\end{array}$ & \\
\hline 0.89 & 0.95 & 0.890 & 0.33 \\
\hline 2.32 & 1.45 & 1.510 & .37 \\
\hline 3.11 & .83 & .970 & .41 \\
\hline 3.65 & .55 & .670 & .43 \\
\hline 4.57 & .97 & 1.225 & .45 \\
\hline
\end{tabular}




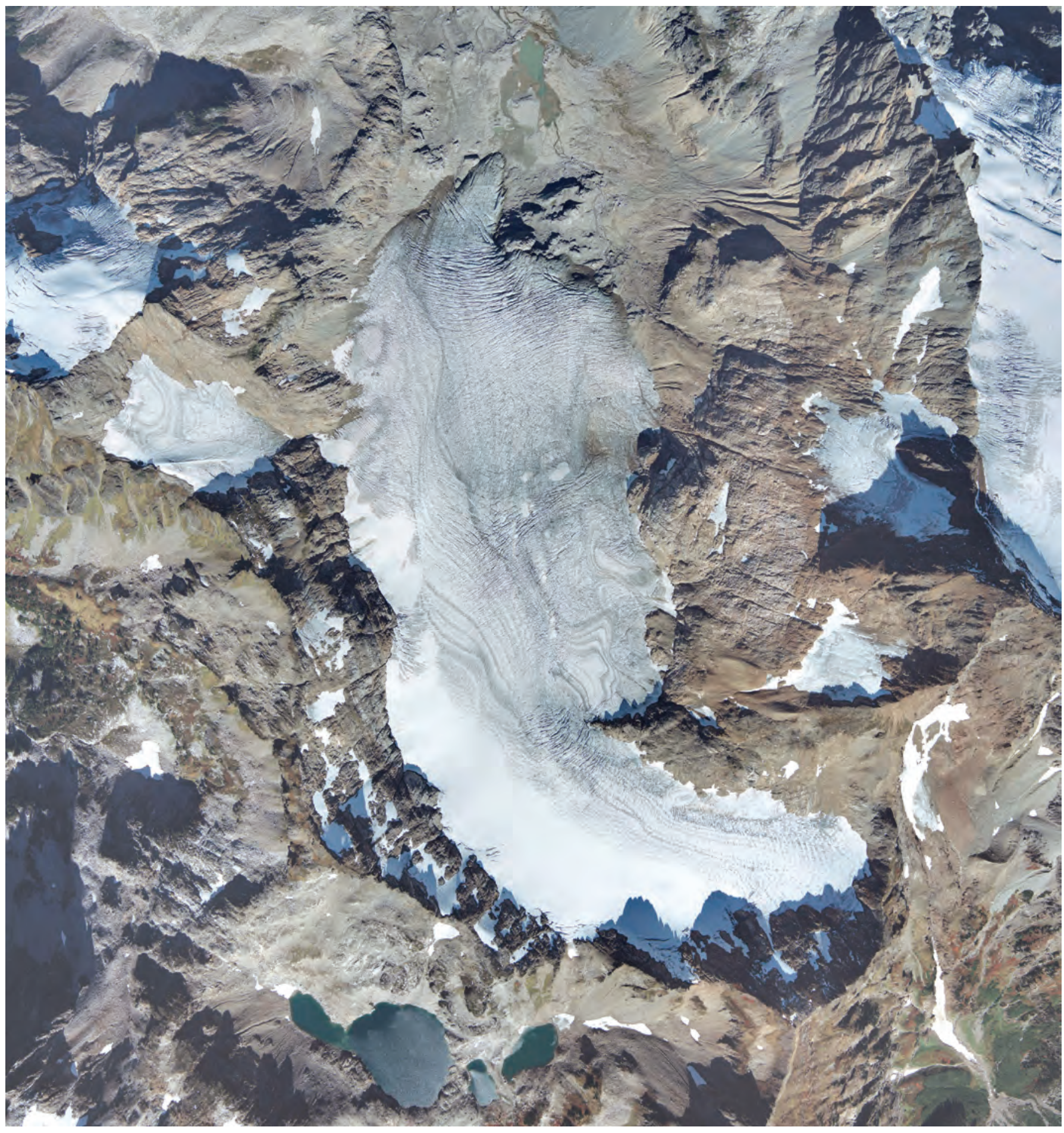

Figure 15. South Cascade Glacier, Washington, September 28, 2006. 
Table 29. Ablation stake measurements at South Cascade Glacier, Washington, balance year 2006.

[Locations of mass balance sites are shown in figure 2. Surface material: SNOW is snow that accumulates after the beginning of the current balance year and until the time of maximum snow accumulation for the year; FIRN is metamorphosed, old snow that has endured at least one summer season; NSNOW (new snow) is snow that accumulates after the time of maximum snow for the current balance year. Surface height is height of glacier surface above 2005 summer melt surface, in meters. Balance components are snow, firn, ice, and new snow gained or lost since the beginning of balance year 2006, with thickness of material gained (loss expressed as negative gain), in meters, and density of material, expressed as a fraction of the density of water. Balance is the sum of all balance components since beginning of balance year 2006, in meters water equivalent. $X$ and $Y$ are easting and northing coordinates in a local coordinate system, in meters, and $Z$ is altitude, in meters. Abbreviations: m, meters; e, estimated or inferred]

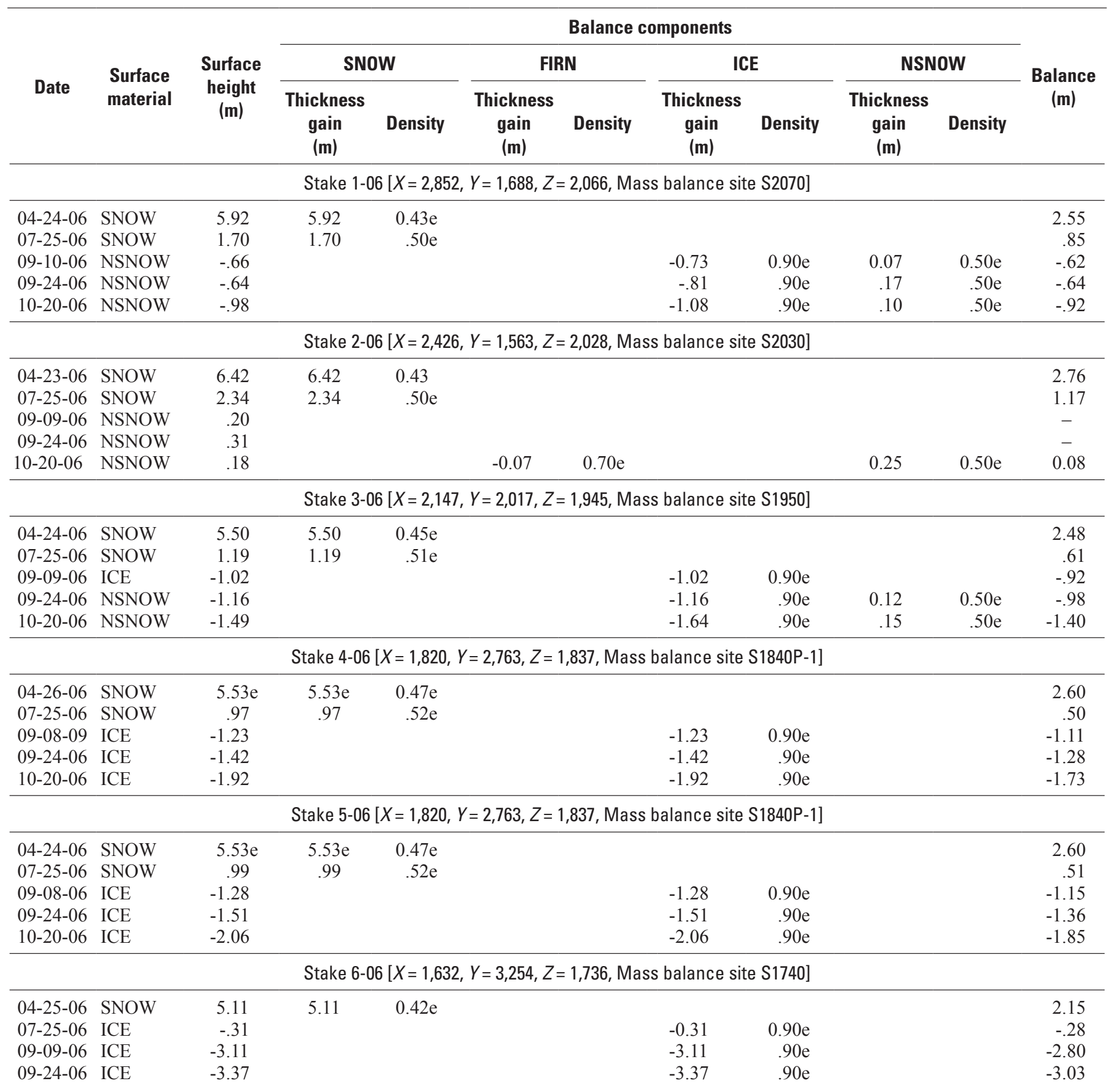


Table 29. Ablation stake measurements at South Cascade Glacier, Washington, balance year 2006.-Continued

[Locations of mass balance sites are shown in figure 2. Surface material: SNOW is snow that accumulates after the beginning of the current balance year and until the time of maximum snow accumulation for the year; FIRN is metamorphosed, old snow that has endured at least one summer season; NSNOW (new snow) is snow that accumulates after the time of maximum snow for the current balance year. Surface height is height of glacier surface above 2005 summer melt surface, in meters. Balance components are snow, firn, ice, and new snow gained or lost since the beginning of balance year 2006, with thickness of material gained (loss expressed as negative gain), in meters, and density of material, expressed as a fraction of the density of water. Balance is the sum of all balance components since beginning of balance year 2006, in meters water equivalent. $X$ and $Y$ are easting and northing coordinates in a local coordinate system, in meters, and $Z$ is altitude, in meters. Abbreviations: m, meters; e, estimated or inferred]

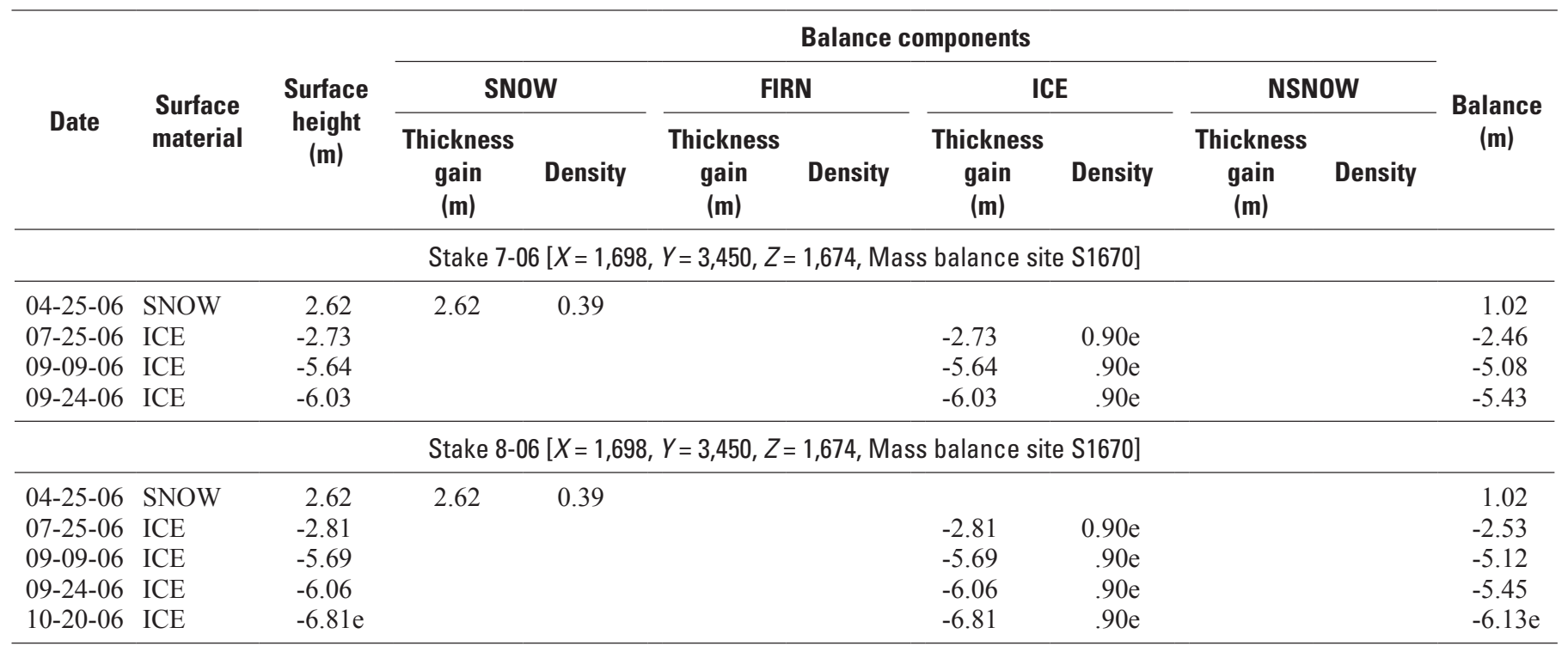

\section{Measured Mass Balances at Selected Sites}

Winter balance glaciological measurements and ablation stake placements at South Cascade Glacier were made during partly stormy weather May 11-15. Snow depth was measured by probing and ablation stakes were placed at each mass balance site and at selected other locations on the glacier (fig. 16). Snow density was measured at three mass balance sites. At some sites, snow depth and snow density were measured on a different day than when the ablation stakes were place. In such instances, snow depth and density at the time the stakes were placed were assumed to equal the depth and density on the day they were measured. Snow depth ranged from $3.00 \mathrm{~m}$ at mass balance site S1670, near the terminus, to $6.07 \mathrm{~m}$ at mass balance site S1840P-1, and to $7.63 \mathrm{~m}$ at site S2030 (table 30, fig. 16). Balance year 2006 had ended with ice exposed at most of the 2007 probing sites, which caused little ambiguity in detecting the 2006 summer surface beneath the 2007 snow pack in most places. Independent measures of mid-May snow depth were made in a few places to test reliability of probing for snow depth. Snow depth determined by digging and auguring to the ice at mass balance site S1840P-1 (6.07 m), the site of ablation stakes 9-07 and 10-07, agreed to within $0.13 \mathrm{~m}$ and 2 percent of the $6.20-\mathrm{m}$ depth measured by probing and the difference could have been caused by the roughness of the glacier surface under the snow pack. Probing also was reliable at mass balance site S2070, the site of ablation stake 4-07 and where the snow pack rested on ice. Late-August auguring through residual snow to the ice indicated $1.64 \mathrm{~m}$ of snow remained, which when added to surface lowering since mid-May $(5.07 \mathrm{~m})$, yielded an initial snow depth $(6.71 \mathrm{~m})$ that agreed to within $0.04 \mathrm{~m}$ and 1 percent of the $6.67-\mathrm{m}$ depth measured by probing during mid-May. Probing for snow depth was not reliable at the site of ablation stake 6-07. Probed snow depth in mid-May was $4.37 \mathrm{~m}$; however, residual snow from the previous winter remained at the site after $5.08 \mathrm{~m}$ of surface lowering by late August. Most likely, the probe had been stopped from penetrating during mid-May by an ice layer within the snow pack.

Finally, probing for snow depth was reliable at mass balance site S2030, the site of ablation stakes 1-07 and 2-07, where the snow pack rested on old firn and where probing had been unreliable the year before. Late-August auguring through residual snow to the top of the firn indicated $2.98 \mathrm{~m}$ of snow remained. The thickness of residual snow measured with the auger, plus surface lowering on stake 1-07 from mid-May to late August (4.80 m), yielded a mid-May snow depth $(7.78 \mathrm{~m})$ that agreed to within $0.15 \mathrm{~m}$ and 2 percent of the depth measured by probing $(7.63 \mathrm{~m})$. 


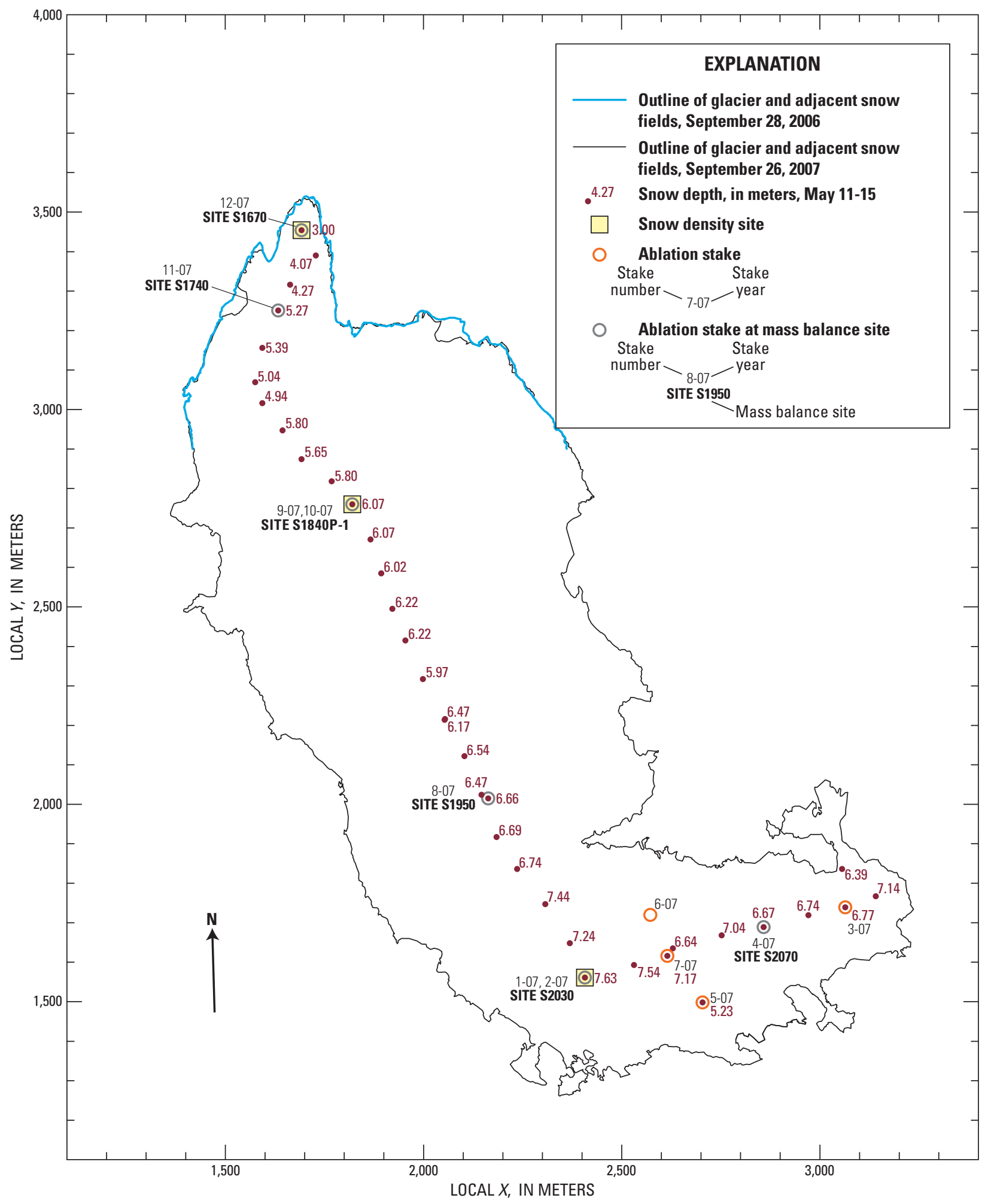

Figure 16. Partial and complete outlines of South Cascade Glacier, Washington, 2006 and 2007, and locations of 2007 measurement sites for snow depth and density and ablation stakes. Snow depth, in meters, is presented next to the measurement site and also is presented in table 30. 
Table 30. Snow depth and snow mass balance at selected locations on South Cascade Glacier, Washington, May 2007.

[Entries for mass balance sites are bolded. Abbreviations: e, estimated; $X$ and $Y$ are easting and northing coordinates in a local coordinate system, meters; and $Z$ is altitude, meters; mWE, meters water equivalent]

\begin{tabular}{|c|c|c|c|c|}
\hline$x$ & $Y$ & $Z$ & $\begin{array}{l}\text { Snow depth } \\
\text { (meters) }\end{array}$ & $\begin{array}{c}\text { Snow mass } \\
\text { balance } \\
\text { (mWE) }\end{array}$ \\
\hline \multicolumn{5}{|c|}{ May 11} \\
\hline 1,866 & 2,671 & 1,843 & 6.07 & 3.16 \\
\hline 1,893 & 2,585 & 1,853 & 6.02 & 3.13 \\
\hline 1,921 & 2,495 & 1,869 & 6.22 & 3.23 \\
\hline 1,954 & 2,415 & 1,891 & 6.22 & 3.23 \\
\hline 1,998 & 2,317 & 1,912 & 5.97 & 3.10 \\
\hline 2,054 & 2,216 & 1,925 & 6.17 & 3.21 \\
\hline \multicolumn{5}{|c|}{ May 12} \\
\hline 2,053 & 2,214 & 1,925 & 6.47 & 3.36 \\
\hline 2,103 & 2,122 & 1,936 & 6.54 & 3.34 \\
\hline 2,146 & 2,024 & 1,944 & 6.47 & 3.30 \\
\hline 2,184 & 1,917 & 1,962 & 6.69 & 3.41 \\
\hline 2,236 & 1,836 & 1,986 & 6.74 & 3.44 \\
\hline 2,307 & 1,747 & 2,006 & 7.44 & 3.79 \\
\hline 2,369 & 1,648 & 2,019 & 7.24 & 3.69 \\
\hline 2,407 & 1,561 & 2,026 & 7.63 & 3.89 \\
\hline 2,531 & 1,593 & 2,034 & 7.54 & 3.85 \\
\hline 2,629 & 1,635 & 2,043 & 6.64 & 3.39 \\
\hline 2,615 & 1,616 & 2,044 & 7.17 & 3.66 \\
\hline 2,752 & 1,668 & 2,055 & 7.04 & 3.59 \\
\hline 2,704 & 1,498 & 2,058 & 5.23 & 2.67 \\
\hline 2,858 & 1,689 & 2,066 & 6.67 & 3.40 \\
\hline 2,971 & 1,719 & 2,077 & 6.74 & 3.44 \\
\hline 3,056 & 1,836 & 2,078 & 6.39 & 3.26 \\
\hline 3,064 & 1,739 & 2,084 & 6.77 & 3.45 \\
\hline 3,141 & 1,767 & 2,089 & 7.14 & 3.64 \\
\hline \multicolumn{5}{|c|}{ May 15} \\
\hline 1,692 & 3,454 & 1,668 & 3.00 & 1.50 \\
\hline 1,728 & 3,390 & 1,683 & 4.07 & 2.04 \\
\hline 1,663 & 3,316 & 1,714 & 4.27 & 2.18 \\
\hline 1,633 & 3,251 & 1,734 & 5.27 & 2.69 \\
\hline 1,593 & 3,156 & 1,770 & 5.39 & 2.75 \\
\hline 1,575 & 3,069 & 1,799 & 5.04 & 2.62 \\
\hline 1,593 & 3,016 & 1,810 & 4.94 & 2.57 \\
\hline 1,644 & 2,947 & 1,821 & 5.80 & 3.02 \\
\hline 1,692 & 2,874 & 1,830 & 5.65 & 2.94 \\
\hline 1,768 & 2,818 & 1,834 & 5.80 & 3.02 \\
\hline $1,820 \mathrm{e}$ & $2,760 \mathrm{e}$ & $1,836 \mathrm{e}$ & 6.07 & 3.16 \\
\hline 2,163 & 2,015 & 1,945 & 6.66 & 3.40 \\
\hline
\end{tabular}

Density of the mid-May 2007 snow pack on South Cascade Glacier was measured through the entire pack thickness at mass balance sites S1670 and S1840P-1 and was measured through part of the thickness at site S2030 on the upper glacier (fig. 16). Density at site S1670 was measured using the specially designed snow corer. Average density of the entire snow thickness was 0.50 (table 31). Average density of the entire snow thickness at site S1840P-1, measured using a combination of samples taken from the wall of a pit and samples extracted with the coring auger, was 0.52 (table 32). Snow density at site S2030 averaged 0.41 to a depth of $3.03 \mathrm{~m}$, where the corer stopped penetrating (table 33). Density of the remaining snow thickness was estimated to equal the average snow density at site S1840P-1 below $3.30 \mathrm{~m}$ depth (0.57). The average snow pack density at site S2030 was computed to be 0.51 .

The snow mass balance overall increased with altitude and distance up-glacier from the terminus. The snow balance ranged from $1.50 \mathrm{mWE}$ at mass balance site $\mathrm{S} 1670,1,668 \mathrm{~m}$ altitude, to $3.16 \mathrm{mWE}$ at site S1840P-1, 1,836 m estimated altitude, and to $3.89 \mathrm{mWE}$ at site S2030, 2,026 m altitude (table 30). The mid-May 2007 snow mass balance at site S1840P-1 was 22 percent greater than the late-April 2006 snow balance at that site.

In late September, South Cascade Glacier remained mostly snow-covered from its head down to mid-glacier at an altitude of about $1,950 \mathrm{~m}$ (fig. 17). A continuous band of residual snow from the previous winter also persisted along the west side of the glacier down to an altitude of about $1,850 \mathrm{~m}$. A series of storms began within a week following the late-September vertical aerial photography and the storms covered most of the glacier for the winter. Depth of new snow on October 14 ranged from 0 at mass balance site S1670, to an average of $0.58 \mathrm{~m}$ at site $\mathrm{S} 1840 \mathrm{P}-1$, and to $0.90 \mathrm{~m}$ at site S2030 on the upper glacier (table 34).

Table 31. Snow density profile measured at mass balance site S1670 near the terminus of South Cascade Glacier, Washington, May 15, 2007.

[Snow density was computed from 60.0-millimeter-diameter samples taken with a snow corer. Location $X=1,690, Y=3,450$, where $X$ and $Y$ are easting and northing coordinates in a local coordinate system, meters; altitude 1,668 meters]

\begin{tabular}{|c|c|c|c|}
\hline \multicolumn{3}{|c|}{ Snow sample } & \multirow{2}{*}{$\begin{array}{l}\text { Sample density } \\
\text { (fraction of } \\
\text { water density) }\end{array}$} \\
\hline $\begin{array}{l}\text { Bottom } \\
\text { (meters) }\end{array}$ & $\begin{array}{l}\text { Length } \\
\text { (meters) }\end{array}$ & $\begin{array}{c}\text { Mass } \\
\text { (kilograms) }\end{array}$ & \\
\hline 0.92 & 0.87 & 1.160 & 0.47 \\
\hline 1.94 & 1.08 & 1.630 & .53 \\
\hline
\end{tabular}


Table 32. Snow density profile measured at mass balance site S1840P-1 on South Cascade Glacier, Washington, May 11, 2007.

[Snow density to a depth of 1.85 meters was computed from 72.3-millimeterdiameter samples taken with a sampling tube from the wall of a pit. Snow density between depths of 1.85 and 6.07 meters was computed from 76.3-millimeter-diameter samples taken with a coring auger. Location estimated to be $X=1,820, Y=2,760$, where $X$ and $Y$ are easting and northing coordinates in a local coordinate system, meters; altitude estimated to be 1,836 meters]

\begin{tabular}{|c|c|c|c|}
\hline \multicolumn{3}{|c|}{ Snow sample } & \multirow{2}{*}{$\begin{array}{l}\text { Sample density } \\
\text { (fraction of } \\
\text { water density) }\end{array}$} \\
\hline $\begin{array}{l}\text { Bottom } \\
\text { (meters) }\end{array}$ & $\begin{array}{l}\text { Length } \\
\text { (meters) }\end{array}$ & $\begin{array}{c}\text { Mass } \\
\text { (kilograms) }\end{array}$ & \\
\hline 0.49 & 0.49 & 0.810 & 0.40 \\
\hline .95 & .46 & .830 & .44 \\
\hline 1.37 & .42 & .805 & .47 \\
\hline 1.85 & .48 & .955 & .48 \\
\hline 2.33 & .49 & 1.130 & .50 \\
\hline 3.30 & .90 & 2.245 & .55 \\
\hline 4.14 & .78 & 2.045 & .57 \\
\hline 4.95 & .71 & 1.810 & .56 \\
\hline 5.71 & .20 & .535 & .59 \\
\hline 6.07 & .38 & .970 & .56 \\
\hline
\end{tabular}

Table 33. Partial snow density profile at mass balance site S2030 on upper South Cascade Glacier, Washington, May 11, 2007.

[Snow density was computed from 60.0-millimeter-diameter samples taken with a snow corer. Location $X=2,410, Y=1,560$, where $X$ and $Y$ are easting and northing coordinates in a local coordinate system, meters; altitude 2,028 meters]

\begin{tabular}{cccc}
\hline & Snow sample & & Sample density \\
(fraction of \\
$\begin{array}{c}\text { Bottom } \\
\text { (meters) }\end{array}$ & $\begin{array}{c}\text { Length } \\
\text { (meters) }\end{array}$ & $\begin{array}{c}\text { Mass } \\
\text { (kilograms) }\end{array}$ & \begin{tabular}{c} 
water density) \\
\hline 1.42
\end{tabular} \\
2.19 & .76 & 1.515 & 0.37 \\
3.03 & .76 & .875 & .41 \\
& .86 & 1.115 & .46 \\
\hline
\end{tabular}




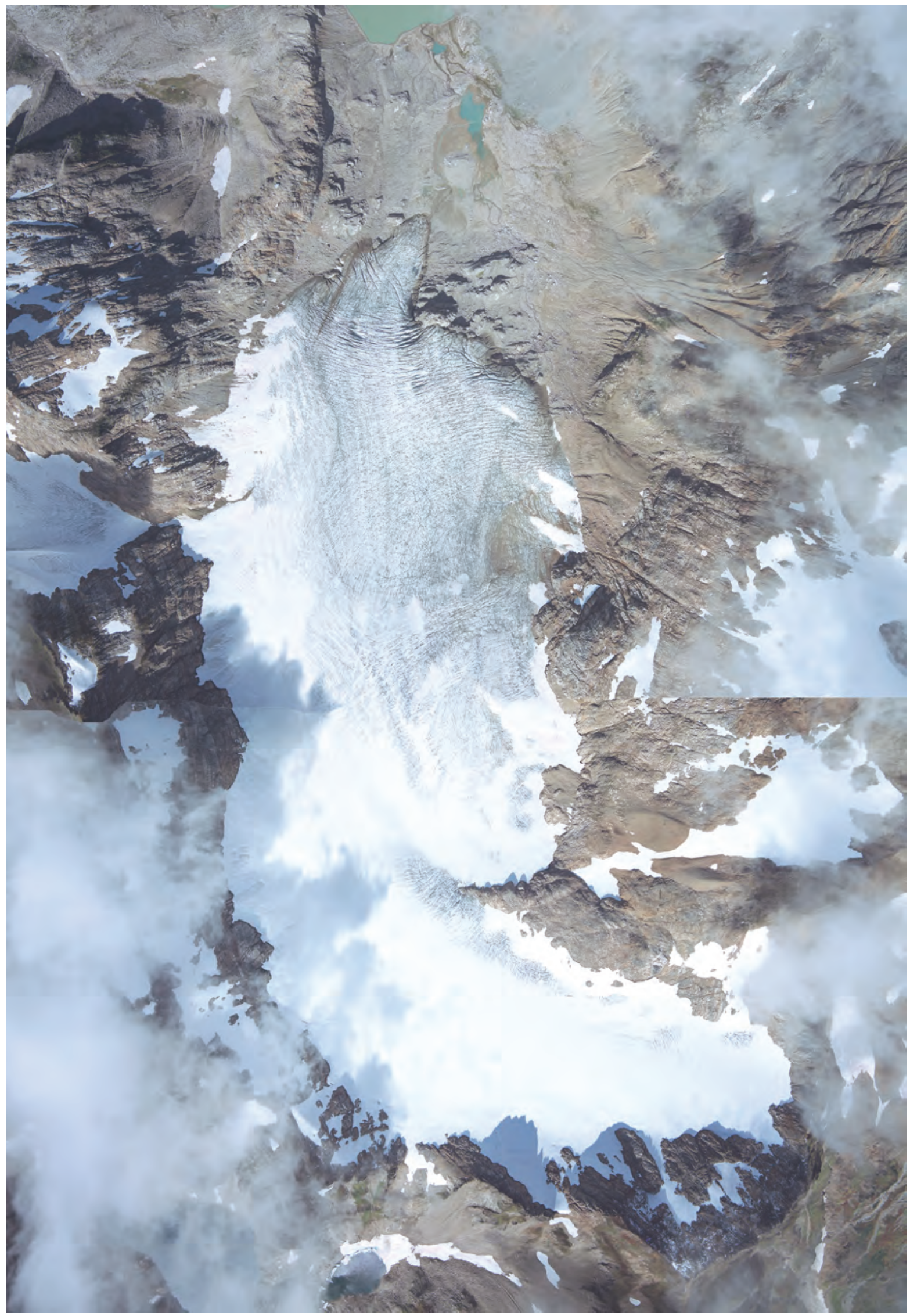

Figure 17. South Cascade Glacier, Washington, constructed from vertical aerial photographs, September 26, 2007. 
Table 34. Ablation stake measurements at South Cascade Glacier, Washington, balance year 2007.

[Locations of mass balance sites are shown in figure 2. Surface material: SNOW is snow that accumulates after the beginning of the current balance year and until the time of maximum snow accumulation for the year; FIRN is metamorphosed, old snow that has endured at least one summer season; NSNOW (new snow) is snow that accumulates after the time of maximum snow for the current balance year. Surface height is height of glacier surface above 2006 summer melt surface, in meters. Balance components are snow, firn, ice, and new snow gained or lost since the beginning of balance year 2007, with thickness of material gained (loss expressed as negative gain), in meters, and density of material, expressed as a fraction of the density of water. Balance is the sum of all balance components since beginning of balance year 2007, in meters water equivalent. $X$ and $Y$ are easting and northing coordinates in a local coordinate system, in meters, and $Z$ is altitude, in meters. Abbreviations: m, meters; e, estimated or inferred; >, greater than]

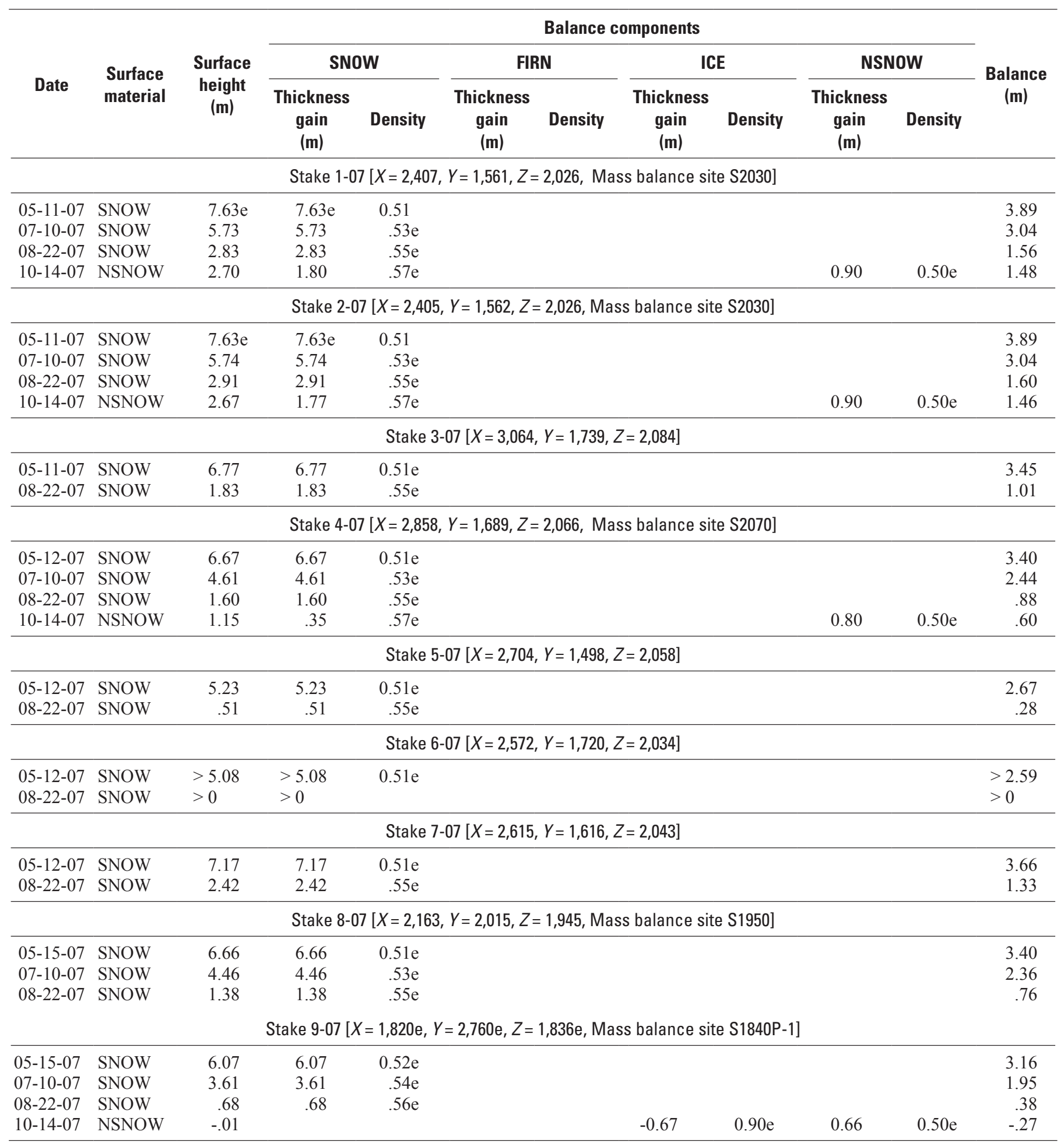


Table 34. Ablation stake measurements at South Cascade Glacier, Washington, balance year 2007.-Continued

[Locations of mass balance sites are shown in figure 2. Surface material: SNOW is snow that accumulates after the beginning of the current balance year and until the time of maximum snow accumulation for the year; FIRN is metamorphosed, old snow that has endured at least one summer season; NSNOW (new snow) is snow that accumulates after the time of maximum snow for the current balance year. Surface height is height of glacier surface above 2006 summer melt surface, in meters. Balance components are snow, firn, ice, and new snow gained or lost since the beginning of balance year 2007, with thickness of material gained (loss expressed as negative gain), in meters, and density of material, expressed as a fraction of the density of water. Balance is the sum of all balance components since beginning of balance year 2007, in meters water equivalent. $X$ and $Y$ are easting and northing coordinates in a local coordinate system, in meters, and $Z$ is altitude, in meters. Abbreviations: $m$, meters; e, estimated or inferred; >, greater than]

\begin{tabular}{|c|c|c|c|c|c|c|c|c|c|c|c|}
\hline \multirow{2}{*}{ Date } & \multirow{2}{*}{$\begin{array}{l}\text { Surface } \\
\text { material }\end{array}$} & \multirow{2}{*}{$\begin{array}{c}\text { Surface } \\
\text { height } \\
\text { (m) }\end{array}$} & \multicolumn{8}{|c|}{ Balance components } & \multirow{2}{*}{$\begin{array}{c}\text { Balance } \\
\text { (m) }\end{array}$} \\
\hline & & & $\begin{array}{l}\text { Thickness } \\
\text { gain } \\
\text { (m) }\end{array}$ & Density & $\begin{array}{l}\text { Thickness } \\
\text { gain } \\
\text { (m) }\end{array}$ & Density & $\begin{array}{l}\text { Thickness } \\
\text { gain } \\
\text { (m) }\end{array}$ & Density & $\begin{array}{l}\text { Thickness } \\
\text { gain } \\
\text { (m) }\end{array}$ & Density & \\
\hline \multicolumn{12}{|c|}{ Stake 10-07 $[X=1,820 \mathrm{e}, Y=2,760 \mathrm{e}, Z=1,836 \mathrm{e}$, Mass balance site $\mathrm{S} 1840 \mathrm{P}-1]$} \\
\hline $07-10-07$ & SNOW & 3.61 & 3.61 & $.54 \mathrm{e}$ & & & & & & & 1.95 \\
\hline $08-22-07$ & SNOW & .72 & .72 & $.56 \mathrm{e}$ & & & & & & & .40 \\
\hline $10-14-07$ & NSNOW & -.06 & & & & & $-0.55 \mathrm{e}$ & $0.90 \mathrm{e}$ & 0.49 & $0.50 \mathrm{e}$ & -.25 \\
\hline \multicolumn{12}{|c|}{ Stake 11-07 $[X=1,633, Y=3,251, Z=1,734$, Mass balance site $S 1740]$} \\
\hline $05-15-07$ & SNOW & 5.27 & 5.27 & $0.51 \mathrm{e}$ & & & & & & & 2.69 \\
\hline \multicolumn{12}{|c|}{ Stake 12-07 $[X=1,692, Y=3,454, Z=1,668$, Mass balance site $S 1670]$} \\
\hline $05-15-07$ & SNOW & 3.00 & 3.00 & 0.50 & & & & & & & 1.50 \\
\hline $07-10-07$ & ICE & -.03 & & & & & -0.03 & $0.90 \mathrm{e}$ & & & -.03 \\
\hline $08-23-07$ & ICE & -3.30 & & & & & -3.30 & $.90 \mathrm{e}$ & & & -2.97 \\
\hline $10-14-07$ & ICE & -5.20 & & & & & -5.20 & $.90 \mathrm{e}$ & & & -4.68 \\
\hline
\end{tabular}

\section{Uncertainties in Measured Mass Balances at Selected Sites}

Uncertainties in measured mass balances arose from errors in measured thickness changes and in measured or estimated density of materials gained or lost. Although rigorous quantification of the errors would require much more sampling and inter-comparison among measurement techniques than was possible for this report, the sources of errors that probably were most important are enumerated here as a possible predicate for future research.

Thickness-change errors primarily were caused by roughness of the glacier surface and by errors in the individual practitioner's judgment of the average height among the roughness elements. Snow pack thickness measured by probing also was affected by the roughness of the melt surface beneath the pack. Errors in measured snow pack thickness due to false detection of the interface between the snow pack and the underlying melt surface, potentially a meter or more, in practice probably were much smaller than that on average because snow depth measured by probing was verified later in the melt season at selected locations as was discussed previously. Slow sinking of the ablation stakes over time was another potential source of error in measured thickness change. A sinking stake during the summer melt season would cause an underestimation of thickness decrease and ablation.

Errors in measured density of the snowpack potentially were caused by the broken, irregular-ended or discontinuous snow core samples that the coring auger sometimes produced, by sample compaction during coring, by the limited resolution of the scales used to weigh the samples (0.01 kilogram), and potentially by the unintentional inclusion of compacted coring shavings as part of the samples. The total error from these causes probably was less than 5 percent of the measured density. Errors in estimated snow pack and firn density could have been much larger, perhaps equaling as much as 10 percent of the estimated density. 
Sources and probably magnitudes of mass balance uncertainties differed over time and among sites. For example, errors in snow density were important for mass balances measured anywhere on the glacier during late winter and early summer, but they vanished along with the snow pack later in the summer season. Thus, the winter balance at any given site was subject to snow density errors, but the net balance at all or most of the sites was not. Errors in estimated firn density were of little importance for computed 2006 and 2007 glacier mass balances because firn was exposed at only one of the six mass balance sites (S2030) during those balance years.

\section{Degree-Day Factors From Selected Sites and Periods, 2003-07}

Mass balance and glacier air temperature data from 2003 to 2007 that were selected to help constrain the allowable ranges for the two model degree-day factors are presented in table 35. Filtering to isolate periods of exclusively snow or firn melt eliminated all data from the two lowest mass balance sites. The remaining data from 18 predominantly summer periods of snow or firn melt yielded degree-day factors that ranged from 0.0027 to 0.0048 meters water equivalent per positive degree day (mWE/PDD) (table 35). The mean and standard deviation of $D D F_{s}$ were 0.0039 and $0.0006 \mathrm{mWE} / \mathrm{PDD}$, respectively. Filtering to isolate periods of exclusively ice melt eliminated data from all but two of the mass balance sites. Degree-day factors for ice, computed from 16 periods of data from sites S1670 and S1840P-1, ranged from 0.0038 to $0.0069 \mathrm{mWE} / \mathrm{PDD}$. The mean and standard deviation of $D D F_{i}$ were 0.0056 and $0.0008 \mathrm{mWE} / \mathrm{PDD}$, respectively.

Degree-day factors are known to vary considerably with place and time (Hock, 2003; Braithwaite, 2008) and the mean degree-day factor for snow and firn presented in this report is well within the ranges reported by other investigators. For example, Hock (2003) summarized results of several studies from different glaciers and reported degree-day factors for glacier snow that ranged from 0.0027 to $0.0116 \mathrm{mWE} / \mathrm{PDD}$. The mean degree-day factor for ice melt from South Cascade Glacier was near the bottom of range ( 0.0054 to $0.0200 \mathrm{mWE} / \mathrm{PDD})$ for that factor in the summary by Hock (2003).

The range of allowable variation in $D D F_{s}$ during calibrations of the full mass balance model to match 2006 and 2007 mass balance observations at selected sites was 0.0033 to $0.0045 \mathrm{mWE} / \mathrm{PDD}$. The range of allowable variation of $D D F_{i}$ was 0.0048 to $0.0064 \mathrm{mWE} / \mathrm{PDD}$. The ranges of allowable variation for $D D F_{s}$ and $D D F_{i}$ were consistent with the expectation that $D D F_{s}$ should be less than $D D F_{i}$ under similar environmental conditions. This difference is because glacier ice absorbs a greater fraction of the solar radiation it receives than snow absorbs. At a given solar irradiance and positive air temperature, more melt would occur from an ice surface than from a snow or firn surface.

\section{Modeled 2006 and 2007 Mass Balances at Selected Sites}

Preliminary simulations with the mass balance model indicated that the entirety of the period of interest for this report, which began with the onset of balance year 2006 and concluded at the end of December 2007, could not be satisfactorily modeled using a single combination of precipitation and degree-day factors for each mass balance site. As a result, two consecutive modeling periods were used for each site and precipitation and degree-day factors were adjusted for each period and site to make the modeled and observed mass balances match (table 36). Adjustments to degree-day factors to improve model fits were constrained by the ranges of allowable variation 4 times among the 12 simulations.

The fitted precipitation and degree-day factors varied systematically in some cases, which might be explained by some physical and statistical causes. Firstly, modeled precipitation increased with site altitude, which was consistent with the common observation that precipitation increases with site altitude on mountain glaciers (Meier and others, 1971; Anslow and others, 2008). The precipitation factor $\left(c_{0}\right)$ and modeled water-year precipitation each correlated with site altitude. Among all sites and modeling periods, the coefficient of correlation between $c_{0}$ and site altitude was 0.65 and the coefficient of correlation between water-year precipitation and site altitude was 0.58 . Secondly, precipitation factors and modeled water-year precipitation were greater for the 2006-2007 modeling periods than for the 2005-2006 periods. The mean $c_{0}$ among all mass balance sites for the 2005-2006 modeling periods was 1.76 and the mean $c_{0}$ among all sites for the 2006-2007 modeling periods was 2.08, which was an increase of 18 percent. Modeled precipitation during water year 2006 ranged from $2.16 \mathrm{~m}$ at site $\mathrm{S} 1670$ to $3.93 \mathrm{~m}$ at site S2030 and it averaged $3.47 \mathrm{~m}$ among all six sites. Modeled precipitation during water year 2007 ranged from $3.19 \mathrm{~m}$ at site $\mathrm{S} 1670$ to $5.11 \mathrm{~m}$ at site $\mathrm{S} 2030$ and it averaged $4.44 \mathrm{~m}$. 
Table 35. Degree-day factors for snow and firn, and ice, computed for selected mass balance sites and periods, South Cascade Glacier, Washington, 2003-07.

[Site locations are shown in figure 2. Melt was computed from mass balance components of snow, firn, and ice that are reported by Bidlake and others (2005 and 2007) and in tables 29 and $\underline{37}$ of this report. Potential accumulation is the precipitation quantity recorded at the Miners Ridge SNOTEL site, in meters, when estimated free-atmosphere temperature at a mass balance site was equal to or less than the threshold for snowfall, $2^{\circ} \mathrm{C}$, and is expressed as the percentage of measured melt. Abbreviations: ${ }^{\circ} \mathrm{C}$, degrees Celsius; mWE, meters water equivalent; $\mathrm{m}$, meter; $\mathrm{mWE} / \mathrm{PDD}$, meters water equivalent per positive degree day; e, estimated]

\begin{tabular}{|c|c|c|c|c|c|c|c|}
\hline \multirow{2}{*}{$\begin{array}{c}\text { Mass balance } \\
\text { site }\end{array}$} & \multirow{2}{*}{$\begin{array}{c}\text { Altitude } \\
\text { (m) }\end{array}$} & \multicolumn{2}{|c|}{ Period } & \multirow{2}{*}{$\begin{array}{c}\text { Melt } \\
\text { (mWE) }\end{array}$} & \multirow{2}{*}{$\begin{array}{l}\text { Positive degree } \\
\text { days }\end{array}$} & \multirow{2}{*}{$\begin{array}{c}\text { Potential } \\
\text { accumulation } \\
\text { (percentage of melt) }\end{array}$} & \multirow{2}{*}{$\begin{array}{c}\text { Degree day } \\
\text { factor } \\
\text { (mWE/PDD) }\end{array}$} \\
\hline & & Start date & End date & & & & \\
\hline \multicolumn{8}{|c|}{ Snow and firn melt } \\
\hline \multirow[t]{2}{*}{ S2070 } & 2,066 & $05-12-07$ & $07-10-07$ & 0.96 & 258 & 10 & 0.0037 \\
\hline & 2,066 & $07-10-07$ & $08-22-07$ & 1.56 & 373 & 0 & .0042 \\
\hline \multirow[t]{8}{*}{ S2030 } & 2,032 & 07-08-03 & $07-25-03$ & .60 & 162 & 0 & .0037 \\
\hline & 2,032 & $07-25-03$ & $08-28-03$ & 1.15 & 304 & 0 & .0038 \\
\hline & 2,032 & $08-28-03$ & $09-20-03$ & .38 & 140 & 5 & .0027 \\
\hline & 2,029 & $07-21-04$ & $08-30-04$ & 1.27 & 384 & 0 & .0033 \\
\hline & 2,029 & $07-14-05$ & $08-02-05$ & .63 & 176 & 0 & .0036 \\
\hline & 2,029 & $08-2-05$ & $08-18-05$ & .49 & 158 & 0 & .0031 \\
\hline & 2,029 & $08-18-05$ & $09-12-05$ & .65 & 150 & 6 & .0043 \\
\hline & 2,029 & 08-18-05 & $09-25-05$ & .86 & 178 & 5 & .0048 \\
\hline S1950 & 1,945 & $04-24-06$ & $07-25-06$ & 1.87 & 526 & 4 & .0036 \\
\hline \multirow[t]{7}{*}{ S1840P-1 } & 1,844 & 07-08-03 & $07-28-03$ & .80 & 178 & 0 & .0045 \\
\hline & 1,842 & $04-25-04$ & $07-21-04$ & 1.36 & 448 & 10 & .0030 \\
\hline & 1,838 & $05-12-05$ & $07-13-05$ & 1.13 & 270 & 9 & .0042 \\
\hline & 1,837 & $04-26-06$ & $07-25-06$ & 2.10 & 508 & 2 & .0041 \\
\hline & 1,837 & 04-24-06 & $07-25-06$ & 2.09 & 511 & 2 & .0041 \\
\hline & $1,836 \mathrm{e}$ & $05-15-07$ & $07-10-07$ & 1.21 & 274 & 7 & .0044 \\
\hline & $1,836 \mathrm{e}$ & 07-10-07 & $08-22-07$ & 1.56 & 357 & 0 & .0044 \\
\hline \multicolumn{8}{|c|}{ Ice melt } \\
\hline \multirow[t]{4}{*}{ S1840P-1 } & 1,844 & $08-27-03$ & 09-20-03 & 0.80 & 154 & 1 & 0.0052 \\
\hline & 1,838 & 08-02-05 & $08-17-05$ & .86 & 145 & 0 & .0059 \\
\hline & 1,838 & $08-17-05$ & $09-25-05$ & 1.17 & 197 & 1 & .0059 \\
\hline & 1,838 & 09-25-05 & $10-22-05$ & .35 & 68 & 11 & .0051 \\
\hline \multirow[t]{12}{*}{ S1670 } & 1,670 & $07-08-03$ & $07-26-03$ & 1.3 & 206 & 0 & .0063 \\
\hline & 1,670 & $07-26-03$ & $08-28-03$ & 2.33 & 380 & 0 & .0061 \\
\hline & 1,670 & $08-28-03$ & $09-20-03$ & 1.05 & 213 & 1 & .0049 \\
\hline & 1,670 & $09-20-03$ & $10-24-03$ & 1.45 & 271 & 4 & .0054 \\
\hline & 1,659 & $06-17-04$ & $07-22-04$ & 2.46 & 388 & 0 & .0063 \\
\hline & 1,683 & $05-13-05$ & $07-14-05$ & 2.40 & 364 & 2 & .0066 \\
\hline & 1,683 & $07-14-05$ & 08-18-05 & 2.28 & 414 & 0 & .0055 \\
\hline & 1,683 & 08-18-05 & $09-25-05$ & 1.31 & 268 & 0 & .0049 \\
\hline & 1,674 & $07-25-06$ & 09-09-06 & 2.61 & 476 & 0 & .0055 \\
\hline & 1,674 & 09-09-06 & $09-24-06$ & .34 & 89 & 7 & .0038 \\
\hline & 1,668 & $07-10-07$ & $08-23-07$ & 2.94 & 428 & 0 & .0069 \\
\hline & 1,668 & $08-23-07$ & $10-14-07$ & 1.71 & 288 & 6 & .0059 \\
\hline
\end{tabular}


Table 36. Mass balance modeling periods, fitted precipitation and degree-day factors, selected fit statistics, and selected characteristics of mass balance sites on South Cascade Glacier, Washington, October 2005 to December 2007.

[Site locations are shown in figure 2. Abbreviations: $c_{0}$, precipitation factor, dimensionless; $D D F_{s}$, degree-day factor for snow and firn melt, in meters water equivalent per positive degree day; $D D F_{i}$, degree-day factor for ice melt, in meters water equivalent per positive degree day; RMSE, root-meansquare error; mWE, meters water equivalent; -, insufficient data; e, estimated]

\begin{tabular}{|c|c|c|c|c|c|c|c|c|c|}
\hline \multirow{2}{*}{$\begin{array}{c}\text { Mass } \\
\text { balance } \\
\text { site }\end{array}$} & \multirow{2}{*}{$\begin{array}{l}\text { Altitude } \\
\text { (m) }\end{array}$} & \multirow{2}{*}{$\begin{array}{l}\text { Ablation } \\
\text { stake(s) }\end{array}$} & \multicolumn{2}{|c|}{ Modeling period } & \multicolumn{3}{|c|}{ Model factors } & \multirow{2}{*}{$\begin{array}{l}\text { RMSE } \\
\text { (mWE) }\end{array}$} & \multirow{2}{*}{ Sample size } \\
\hline & & & Start date & End date & $c_{0}$ & $D D F_{s}$ & $D D F_{i}$ & & \\
\hline \multirow[t]{2}{*}{ S2070 } & 2,066 & $1-06$ & $10-20-2005$ & 10-19-2006 & 1.87 & 0.0033 & 0.0048 & 0.146 & 8 \\
\hline & 2,066 & $4-07$ & $10-20-2006$ & $12-31-2007$ & 2.15 & .0041 & - & .126 & 4 \\
\hline \multirow[t]{2}{*}{ S2030 } & 2,028 & $2-06$ & $10-20-2005$ & 10-19-2006 & 2.00 & .0030 & - & .162 & 5 \\
\hline & 2,026 & $1-07,2-07$ & $10-20-2006$ & $12-31-2007$ & 2.40 & .0039 & - & .160 & 4 \\
\hline \multirow[t]{2}{*}{ S1950 } & 1,945 & $3-06$ & $10-20-2005$ & $10-19-2006$ & 1.85 & .0034 & .0048 & .133 & 7 \\
\hline & 1,945 & $8-07$ & $10-20-2006$ & $12-31-2007$ & 2.20 & .0044 & .0056 & .029 & 3 \\
\hline \multirow[t]{2}{*}{ S1840P-1 } & 1,837 & $4-06,5-06$ & $10-20-2005$ & $10-19-2006$ & 2.00 & .0040 & .0048 & .092 & 5 \\
\hline & $1,836 \mathrm{e}$ & $9-07,10-07$ & $10-20-2006$ & $12-31-2007$ & 2.25 & .0044 & .0057 & .140 & 5 \\
\hline \multirow[t]{2}{*}{ S1740 } & 1,736 & $6-06$ & $10-20-2005$ & $09-24-2006$ & 1.75 & .0039 & .0055 & .070 & 4 \\
\hline & 1,734 & $11-07$ & $09-25-2006$ & $12-31-2007$ & 2.00 & .0045 & .0063 & .251 & 3 \\
\hline \multirow[t]{2}{*}{ S1670 } & 1,674 & 7-06, 8-06 & $10-20-2005$ & 10-19-2006 & 1.10 & .0042 & .0055 & .186 & 5 \\
\hline & 1,668 & 12-07 & $10-20-2006$ & $12-31-2007$ & 1.50 & .0044 & .0068 & .075 & 4 \\
\hline
\end{tabular}

Differences in the precipitation factors between the 2005-2006 and 2006-2007 modeling periods likely were partly caused by variation of the precipitation distribution over the North Cascades from year to year. An example of the year-to-year regional variation of gaged precipitation at different North Cascades sites can be seen in the ratio of water-year precipitation gaged at the Miners Ridge SNOTEL site to that concomitantly gaged at Diablo Dam (fig. 1; National Climatic Data Center, 2009). The ratio ranged from 0.83 to 0.94 among water years 2003-2005, it was 1.12 in water year 2006, and was 0.93 in water year 2007. The ratio of precipitation at Miners Ridge to precipitation at South Cascade Glacier also probably varied from year to year, which might help explain the differences in $c_{0}$ and modeled precipitation between the 2005-2006 and 2006-2007 periods.

The fitted degree-day factors correlated negatively with site altitude (table 36), which was contrary to physically based arguments by Ohmura (2001) and Hock (2003) that degree-day factors should increase with increasing altitude, if they vary at all. The basis of the argument is that the lower air temperature at higher altitudes reduces the fraction of sensible heat flux among all of the energy components contributing to melt, which includes down-welling long-wave and incoming short-wave radiation, but has little effect on contributions from the other energy components. The overall coefficients of correlation for variation of $D D F_{s}$ and $D D F_{i}$ with altitude on South Cascade Glacier were -0.60 and -0.69 , respectively. A negative correlation is one in which a positive variation in one variable is associated with a negative variation in the other variable. The correlations would have been stronger if the degree-day factors had not been constrained by the allowable ranges of variation. That the fitted degree-day factors decreased with increasing altitude could have been party due to the previously discussed statistical interdependence among the precipitation and degree-day factors. Specifically, an overestimation of precipitation by the model could be compensated for by an overestimation of melt.

Two lines of evidence support the notion that the fitted precipitation and degree-day factors were influenced by compensating errors in modeled accumulation and melt. Firstly, the $0.97-\mathrm{m}$ increase in average modeled precipitation from the 2005-2006 to the 2006-2007 modeling periods was accompanied by overall increases of both degree-day factors. The average degree-day factor for snow and firn increased from 0.0036 to $0.0043 \mathrm{mWE} / \mathrm{PDD}$ and the average degree-day factor for ice increased from 0.0051 to $0.0061 \mathrm{mWE} / \mathrm{PDD}$. Secondly, the independently computed degree-day factors used to develop the ranges of allowable variation for $D D F_{s}$ and $D D F_{i}$ (table 35) did not correlate with altitude, indicating the factors did not vary systematically with altitude when effects of precipitation were removed.

Constraining the degree-day factors did not completely remedy effects of the underlying interdependence among the precipitation and degree-day factors, but it did help to assure the physical plausibility of the modeled mass balances by assuring that $D D F_{s}$ always was greater than $D D F_{i}$. Application of the constraints also reduced the number of sets of factors with which the model would predict essentially the same mass balance at a given site. Reducing the number of sets made the final choices of factors easier and less subjective. 
Variations of modeled mass balances of snow, firn, and ice with time at selected sites reveal when and where the glacier gained and lost mass at its surface (igg. 18). The glacier gained mass for the balance year at some sites from winter accumulation of snow that persisted throughout the summer season and became new, first-year firn. By definition, residual snow from the most recent winter becomes new firn when it is covered by fresh snow of the upcoming winter. No new firn formed at the end of summer 2006, but new firn formed at the highest two sites at the end of summer 2007. The glacier lost mass for the year at some sites by ablation of ice and old firn that had previously formed from snow that accumulated before the most recent winter. The most negative ice mass balances occurred at the two lowest sites. Losses of ice and old firn were greater at every site during balance year 2006 than during 2007. No ice or old firn were lost from the two highest sites during balance year 2007. The 2007 ice and old firn losses were smaller partly because summer 2007 was cooler than summer 2006 and because the larger overburden of snow during 2007 had to be ablated before the ice and old firn were exposed to the elements.

Modeled yearly mass balance minimums and maximums often occurred on different dates at different sites, with the maximums occurring earlier and the minimums occurring later at lower-altitude sites (fig. 19). Date of the maximum 2006 mass balance differed by only 1 day among the six mass balance sites, but the date of the minimum 2006 mass balance differed by as much as 9 days. Date of the maximum 2007 mass balance did not differ among the mass balance sites, but the date of the minimum 2007 mass balance differed by as much as 43 days.

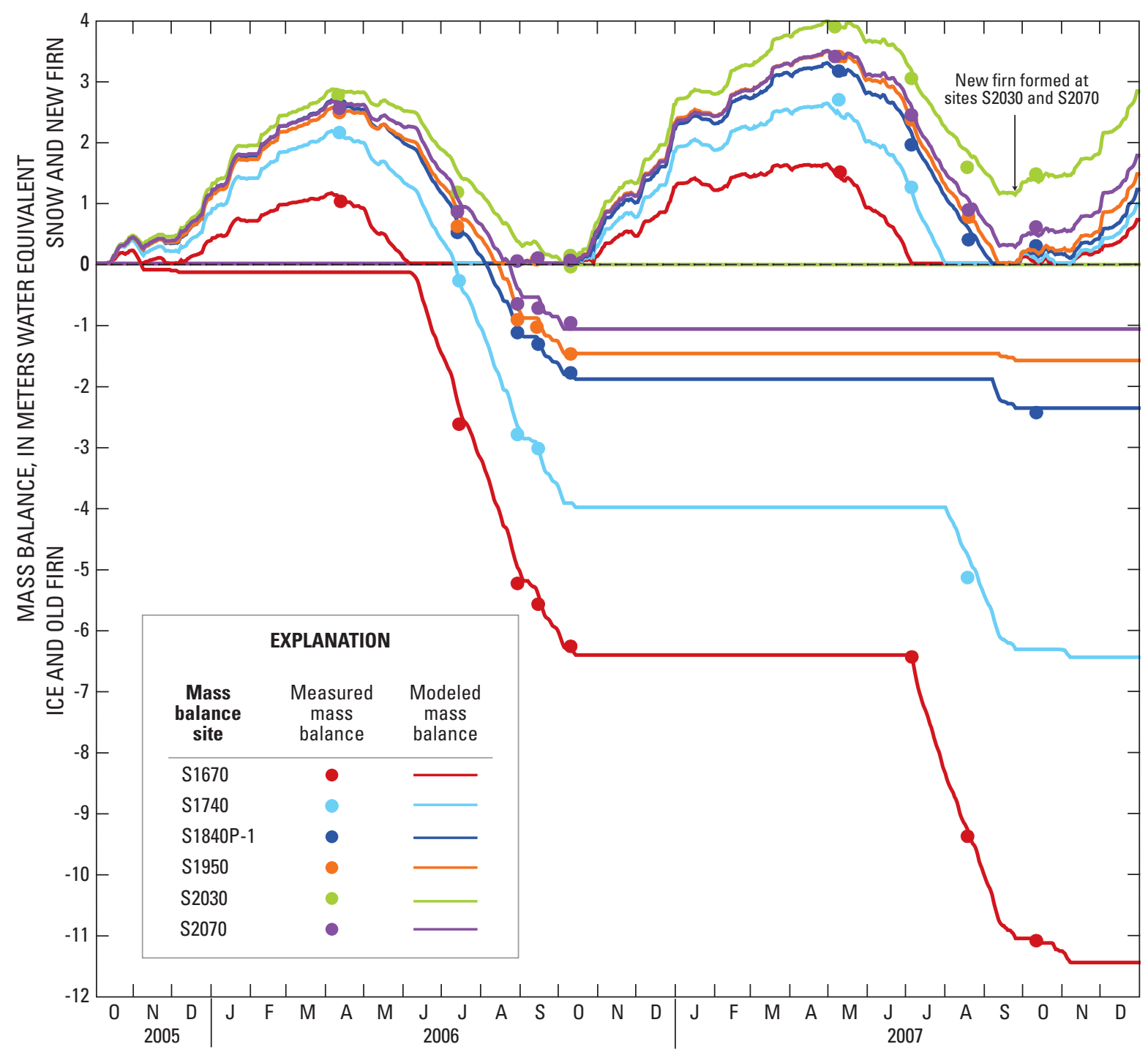

Figure 18. Cumulative snow and new firn, and ice mass balances at six mass balance sites on South Cascade Glacier, Washington, from the beginning of balance year 2006 to December 31, 2007. Mass balances were referenced to the surface formed at the start of balance year 2006. 

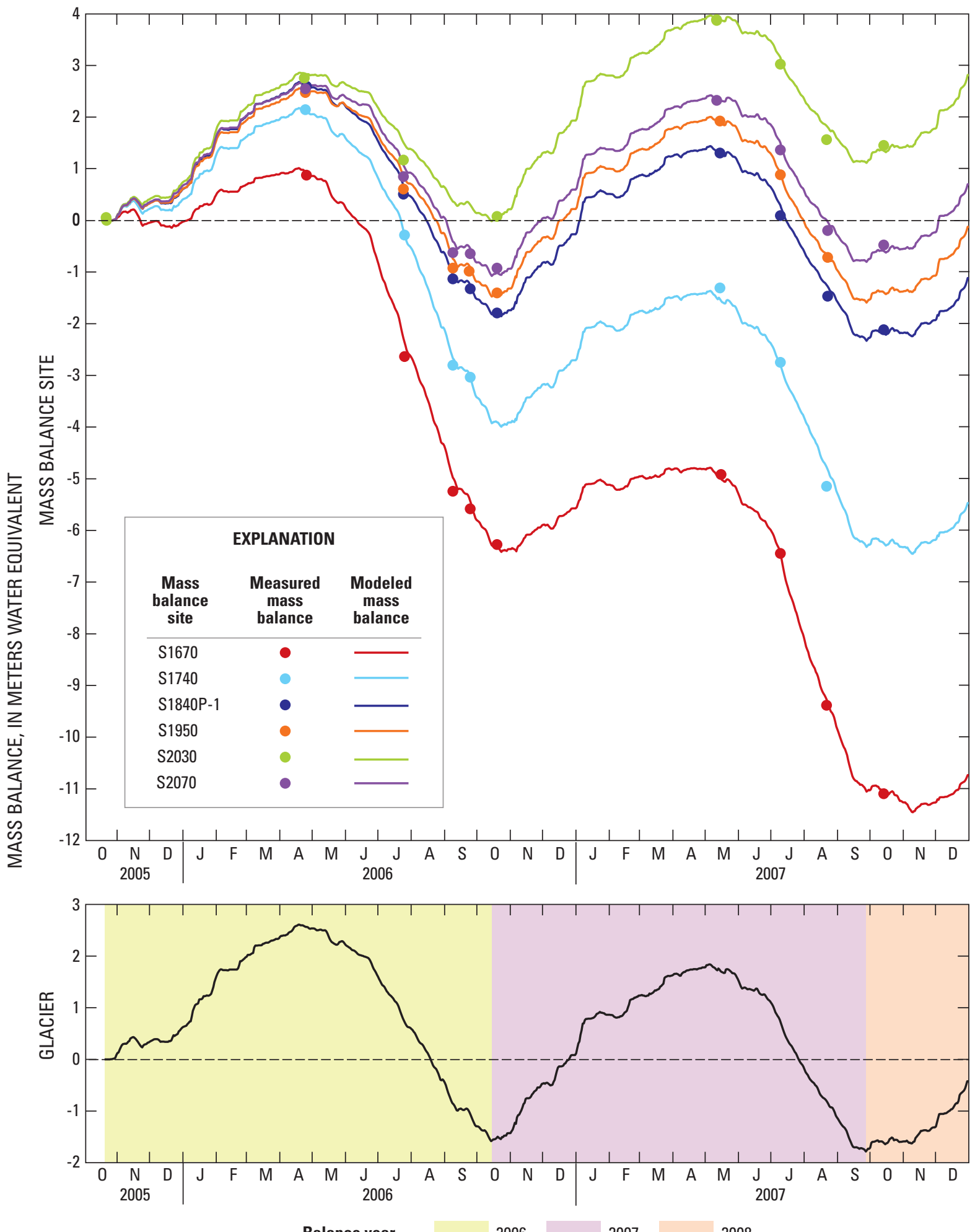

Balance year

2006

2007

2008

Figure 19. Mass balances at six mass balance sites on South Cascade Glacier, Washington, and glacier mass balance, from the beginning of balance year 2006 to December 31, 2007. Mass balances were referenced to the surface formed at the start of balance year 2006 . 
Some limitations were noted in the simple mass balance model as it was applied in this report. One of the most substantial limitations was that the model was strictly empirical and correlative in nature and relatively few data were available with which to calibrate it and test its reliability. This deficiency of samples was especially important because of the statistical interdependence among the precipitation and degree-day factors. Another important limitation was the model did not account for accumulation by snow redistribution. Snow is known to avalanche onto the glacier, but the importance of such accumulations to local balances is not well understood. The amount of wind-blown snow deposited and scoured at various locations also is not known.

\section{Glacier Surface-Altitude Grids}

Aerial photographs analyzed to make the 2006 surface-altitude grids were acquired under cloudless and almost ideal conditions September 28 (fig. 15). The TIN created during the automated photogrammetry process was manually edited for small areas near the terminus, for featureless snow-covered areas on the upper glacier, and for selected places off glacier. A digital file of the 2-m-spaced grid data for South Cascade Lake basin can be found on a CD-ROM that is included with this report.

Aerial photographs analyzed to make the 2007 surface-altitude grids were acquired under poor, partly cloudy conditions September 26 (fig. 17). The TIN created during the automated photogrammetry process required extensive manual editing and surface altitude in some areas of glacier could not be measured by any means. The 2 -m-spaced surface-altitude grid was created for the area of the glacier only and some areas of that grid were blanked because altitudes were thought to be unreliable. A digital file of the grid data is available on the CD-ROM that accompanies this report. Grid points of the 2007 100-m-spaced grid that were within blanked areas of the 2-m-spaced grid were assigned corresponding altitudes from the 2006 100-m-spaced grid.

The 2006 and 2007 100-m-spaced glacier surface-altitude grids each comprised 174 grid points (figs. 20 and 21). Altitudes of all the 2006 grid points and seven of the 2007 grid points were obtained from the 2006 photographs. The minimum and maximum altitude of points in the 2006 grid were 1,688 and 2,118 m, respectively, and the mean grid-point altitude was $1,918 \mathrm{~m}$ (table 37). The minimum and maximum altitude of points in the 2007 grid were 1,645 and 2,118 m, respectively, and the mean grid-point altitude was $1,919 \mathrm{~m}$ (table 38).

\section{Glacier Mass Balances}

The glacier measured winter snow balance, $\bar{b}_{\mathrm{m}}(\mathrm{s})$, is the only type of glacier balance presented in this report that was computed without relying on mass balance modeling to estimate mass balances at selected sites at critical times of the year. The 2006 and $2007 \bar{b}_{\mathrm{m}}$ (s) were computed on the basis of measured snow depth and density at the time of winter balance measurements (tables 25 and $\underline{30}$ ). Other glacier mass balances presented were computed on the basis of the modeled mass balances at the six mass balance sites.

\section{Glacier Winter, Summer, Net, and Annual Balances}

Results from mass balance modeling disagreed with the conclusions of Bidlake and others (2007) that balance year 2005 was ended by snow accumulation on the upper glacier October 19, 2005. The mass balance model indicated the glacier continued to slowly lose mass at each of the six mass balance sites until October 25, during which time the glacier lost an additional $0.12 \mathrm{mWE}$ of firn and ice. The differences between the model-predicted mass minimum and date and those reported by Bidlake and others (2007) likely were within the margin of uncertainty in both modeled and measured mass balances and no revisions to previously reported data are necessary.

The $2006 \bar{b}_{\mathrm{m}}$ (s) of South Cascade Glacier, computed using the 40 snow mass balances presented in table 25, was $2.55 \mathrm{mWE}$, which was $0.58 \mathrm{mWE}$ more positive (greater) than the $2005 \bar{b}_{\mathrm{m}}$ (s) computed for April 20-21 of the previous year (Bidlake and others, 2007).

The 2006 glacier maximum winter snow balance $\left(\bar{b}_{\mathrm{w}}(\mathrm{s})\right)$ of $2.61 \mathrm{mWE}$ occurred April 18, which was 5 days before the 2006 snow measurements began. Snow mass balances at the six mass balance sites at the time of the glacier maximum winter snow balance are given in table 39 . The 2006 fractional attribution of glacier mass balance to each mass balance site is also presented in table 39. The 2006 $\bar{b}_{\mathrm{w}}$ (s) was $0.64 \mathrm{mWE}$ greater than the exceptionally small $2005 \bar{b}_{\mathrm{w}}(\mathrm{s})(1.97 \mathrm{mWE})$ and it was the largest since 2003 (fig. 22).

The 2006 glacier summer balance ( $\left.\bar{b}_{\mathrm{s}}\right)$ of $-4.20 \mathrm{mWE}$ was only slightly less negative than the $2005 \bar{b}_{\mathrm{s}}$, despite the warmer 2006 June-September that was discussed previously. Bidlake and others (2007) noted that the $2005 \bar{b}_{\mathrm{s}}$ was uncommonly negative, given that the average June-September air temperature at the Hut was only $8.1^{\circ} \mathrm{C}$, which was $2.0^{\circ} \mathrm{C}$ colder than June-September 2006. Possible reasons for the strongly negative $2005 \bar{b}_{\text {s }}$ included the atypically warm May 2005 and prolonged exposure of glacier ice to ablation because of the thin winter 2006 snow pack. 


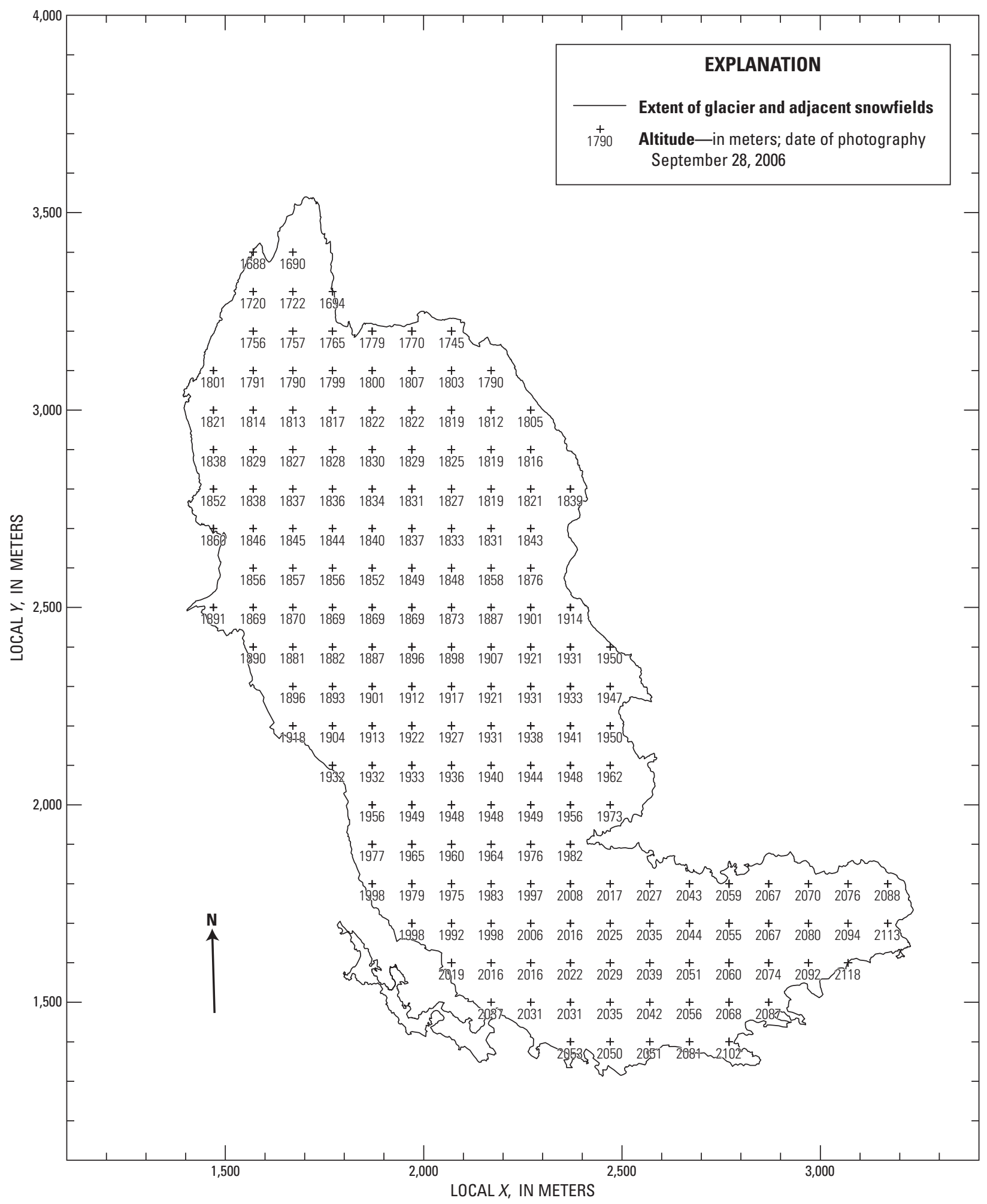

Figure 20. 2006 surface-altitude grid for South Cascade Glacier, measured from vertical aerial photographs taken September 28, 2006. Grid spacing is 100 meters; grid data are presented in table 37. 


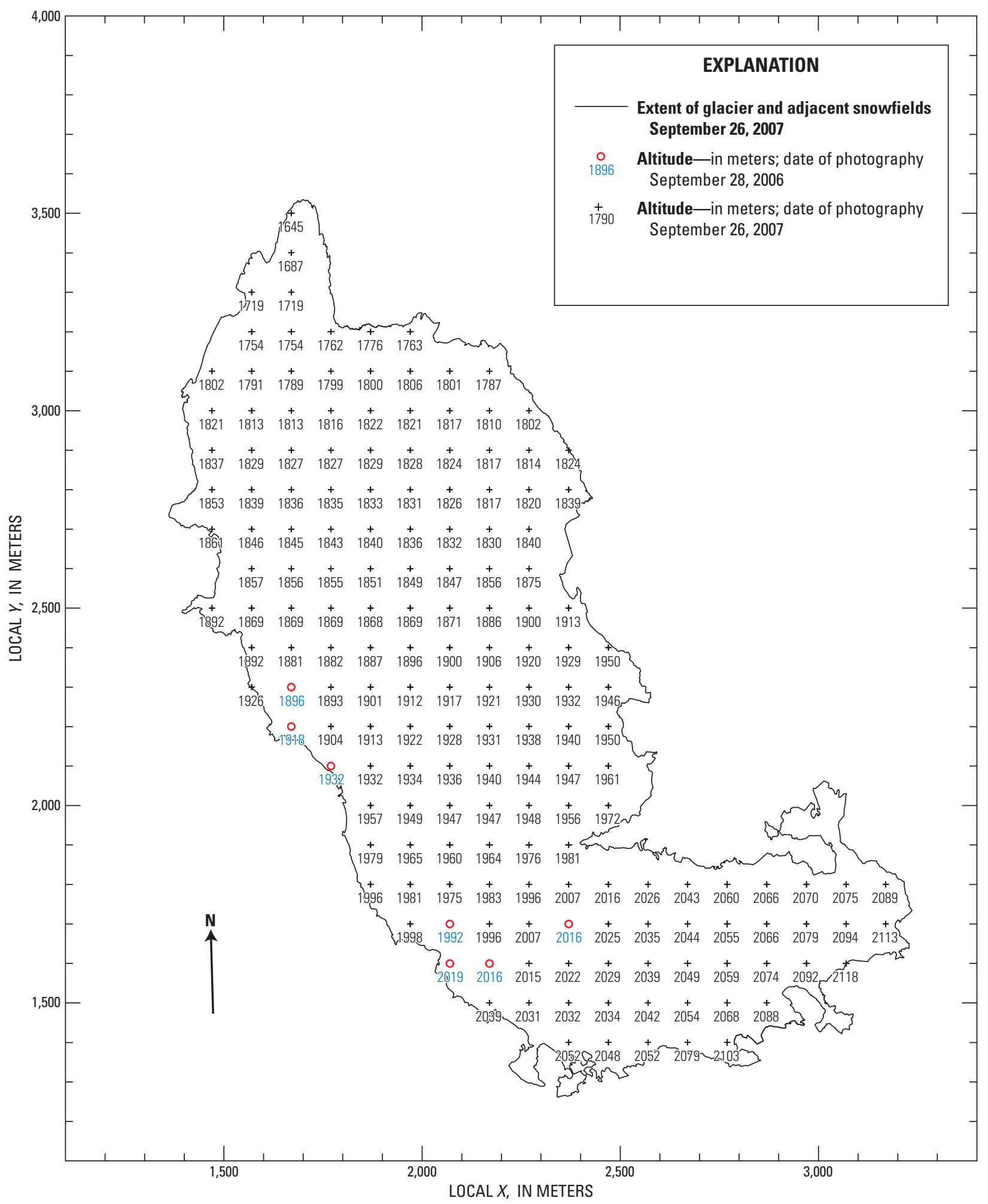

Figure 21. Map showing 2007 surface-altitude grid for South Cascade Glacier, measured from vertical aerial photographs taken September 28, 2006, and September 26, 2007. Grid spacing is 100 meters; grid data are presented in table 38. 
Table 37. Surface-altitude grid with 100-meter spacing for South Cascade Glacier, Washington, 2006.

[Year, calendar year of aerial photography; $X$ and $Y$ are easting and northing coordinates in a local coordinate system, meters; $Z$ is altitude, meters]

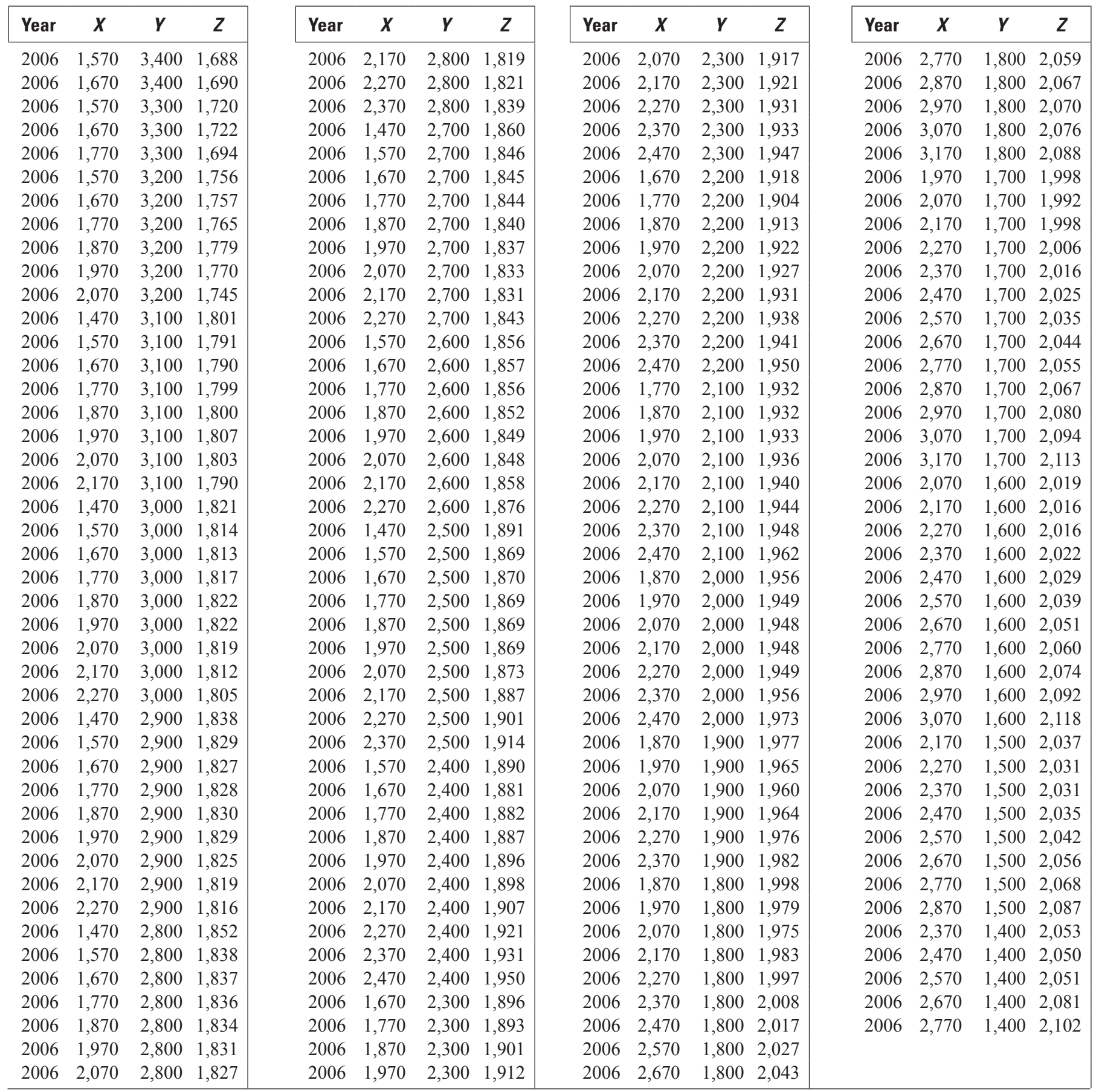


Table 38. Surface-altitude grid with 100-meter spacing for South Cascade Glacier, Washington, 2007.

[Year, calendar year of aerial photography; $X$ and $Y$ are easting and northing coordinates in a local coordinate system, meters; $Z$ is altitude, meters]

\begin{tabular}{|cccc|}
\hline Year & $\boldsymbol{X}$ & $\boldsymbol{Y}$ & $\boldsymbol{Z}$ \\
\hline 2007 & 1,670 & 3,500 & 1,645 \\
2007 & 1,670 & 3,400 & 1,687 \\
2007 & 1,570 & 3,300 & 1,719 \\
2007 & 1,670 & 3,300 & 1,719 \\
2007 & 1,570 & 3,200 & 1,754 \\
2007 & 1,670 & 3,200 & 1,754 \\
2007 & 1,770 & 3,200 & 1,762 \\
2007 & 1,870 & 3,200 & 1,776 \\
2007 & 1,970 & 3,200 & 1,763 \\
2007 & 1,470 & 3,100 & 1,802 \\
2007 & 1,570 & 3,100 & 1,791 \\
2007 & 1,670 & 3,100 & 1,789 \\
2007 & 1,770 & 3,100 & 1,799 \\
2007 & 1,870 & 3,100 & 1,800 \\
2007 & 1,970 & 3,100 & 1,806 \\
2007 & 2,070 & 3,100 & 1,801 \\
2007 & 2,170 & 3,100 & 1,787 \\
2007 & 1,470 & 3,000 & 1,821 \\
2007 & 1,570 & 3,000 & 1,813 \\
2007 & 1,670 & 3,000 & 1,813 \\
2007 & 1,770 & 3,000 & 1,816 \\
2007 & 1,870 & 3,000 & 1,822 \\
2007 & 1,970 & 3,000 & 1,821 \\
2007 & 2,070 & 3,000 & 1,817 \\
2007 & 2,170 & 3,000 & 1,810 \\
2007 & 2,270 & 3,000 & 1,802 \\
2007 & 1,470 & 2,900 & 1,837 \\
2007 & 1,570 & 2,900 & 1,829 \\
2007 & 1,670 & 2,900 & 1,827 \\
2007 & 1,770 & 2,900 & 1,827 \\
2007 & 1,870 & 2,900 & 1,829 \\
2007 & 1,970 & 2,900 & 1,828 \\
2007 & 2,070 & 2,900 & 1,824 \\
2007 & 2,170 & 2,900 & 1,817 \\
2007 & 2,270 & 2,900 & 1,814 \\
2007 & 2,370 & 2,900 & 1,824 \\
2007 & 1,470 & 2,800 & 1,853 \\
2007 & 1,570 & 2,800 & 1,839 \\
2007 & 1,670 & 2,800 & 1,836 \\
2007 & 1,770 & 2,800 & 1,835 \\
2007 & 1,870 & 2,800 & 1,833 \\
2007 & 1,970 & 2,800 & 1,831 \\
2007 & 2,170 & 2,800 & 1,817 \\
\hline & & & \\
2007 & 2,800 & 1,826 \\
20070
\end{tabular}

\begin{tabular}{cccc|}
\hline Year & $\boldsymbol{X}$ & $\boldsymbol{Y}$ & $\boldsymbol{Z}$ \\
\hline 2007 & 2,270 & 2,800 & 1,820 \\
2007 & 2,370 & 2,800 & 1,839 \\
2007 & 1,470 & 2,700 & 1,861 \\
2007 & 1,570 & 2,700 & 1,846 \\
2007 & 1,670 & 2,700 & 1,845 \\
2007 & 1,770 & 2,700 & 1,843 \\
2007 & 1,870 & 2,700 & 1,840 \\
2007 & 1,970 & 2,700 & 1,836 \\
2007 & 2,070 & 2,700 & 1,832 \\
2007 & 2,170 & 2,700 & 1,830 \\
2007 & 2,270 & 2,700 & 1,840 \\
2007 & 1,570 & 2,600 & 1,857 \\
2007 & 1,670 & 2,600 & 1,856 \\
2007 & 1,770 & 2,600 & 1,855 \\
2007 & 1,870 & 2,600 & 1,851 \\
2007 & 1,970 & 2,600 & 1,849 \\
2007 & 2,070 & 2,600 & 1,847 \\
2007 & 2,170 & 2,600 & 1,856 \\
2007 & 2,270 & 2,600 & 1,875 \\
2007 & 1,470 & 2,500 & 1,892 \\
2007 & 1,570 & 2,500 & 1,869 \\
2007 & 1,670 & 2,500 & 1,869 \\
2007 & 1,770 & 2,500 & 1,869 \\
2007 & 1,870 & 2,500 & 1,868 \\
2007 & 1,970 & 2,500 & 1,869 \\
2007 & 2,070 & 2,500 & 1,871 \\
2007 & 2,170 & 2,500 & 1,886 \\
2007 & 2,270 & 2,500 & 1,900 \\
2007 & 2,370 & 2,500 & 1,913 \\
2007 & 1,570 & 2,400 & 1,892 \\
2007 & 1,670 & 2,400 & 1,881 \\
2007 & 1,770 & 2,400 & 1,882 \\
2007 & 1,870 & 2,400 & 1,887 \\
2007 & 1,970 & 2,400 & 1,896 \\
2007 & 2,070 & 2,400 & 1,900 \\
2007 & 2,170 & 2,400 & 1,906 \\
2007 & 2,270 & 2,400 & 1,920 \\
2007 & 2,370 & 2,400 & 1,929 \\
2007 & 2,470 & 2,400 & 1,950 \\
2007 & 1,570 & 2,300 & 1,926 \\
2007 & 1,670 & 2,300 & 1,896 \\
2007 & 1,770 & 2,300 & 1,893 \\
2007 & 1,870 & 2,300 & 1,901 \\
& & 2,300 & 1,912 \\
\hline
\end{tabular}

\begin{tabular}{|cccc|}
\hline Year & $\boldsymbol{X}$ & $\boldsymbol{Y}$ & $\boldsymbol{Z}$ \\
\hline 2007 & 2,070 & 2,300 & 1,917 \\
2007 & 2,170 & 2,300 & 1,921 \\
2007 & 2,270 & 2,300 & 1,930 \\
2007 & 2,370 & 2,300 & 1,932 \\
2007 & 2,470 & 2,300 & 1,946 \\
2007 & 1,670 & 2,200 & 1,918 \\
2007 & 1,770 & 2,200 & 1,904 \\
2007 & 1,870 & 2,200 & 1,913 \\
2007 & 1,970 & 2,200 & 1,922 \\
2007 & 2,070 & 2,200 & 1,928 \\
2007 & 2,170 & 2,200 & 1,931 \\
2007 & 2,270 & 2,200 & 1,938 \\
2007 & 2,370 & 2,200 & 1,940 \\
2007 & 2,470 & 2,200 & 1,950 \\
2007 & 1,770 & 2,100 & 1,932 \\
2007 & 1,870 & 2,100 & 1,932 \\
2007 & 1,970 & 2,100 & 1,934 \\
2007 & 2,070 & 2,100 & 1,936 \\
2007 & 2,170 & 2,100 & 1,940 \\
2007 & 2,270 & 2,100 & 1,944 \\
2007 & 2,370 & 2,100 & 1,947 \\
2007 & 2,470 & 2,100 & 1,961 \\
2007 & 1,870 & 2,000 & 1,957 \\
2007 & 1,970 & 2,000 & 1,949 \\
2007 & 2,070 & 2,000 & 1,947 \\
2007 & 2,170 & 2,000 & 1,947 \\
2007 & 2,270 & 2,000 & 1,948 \\
2007 & 2,370 & 2,000 & 1,956 \\
2007 & 2,470 & 2,000 & 1,972 \\
2007 & 1,870 & 1,900 & 1,979 \\
2007 & 1,970 & 1,900 & 1,965 \\
2007 & 2,070 & 1,900 & 1,960 \\
2007 & 2,170 & 1,900 & 1,964 \\
2007 & 2,270 & 1,900 & 1,976 \\
2007 & 2,370 & 1,900 & 1,981 \\
2007 & 1,870 & 1,800 & 1,996 \\
2007 & 1,970 & 1,800 & 1,981 \\
2007 & 2,070 & 1,800 & 1,975 \\
2007 & 2,170 & 1,800 & 1,983 \\
2007 & 2,270 & 1,800 & 1,996 \\
2007 & 2,370 & 1,800 & 2,007 \\
2007 & 2,470 & 1,800 & 2,016 \\
2007 & 2,670 & 1,800 & 2,043 \\
& & & \\
2000
\end{tabular}

\begin{tabular}{cccc|}
\hline Year & $\boldsymbol{X}$ & $\boldsymbol{Y}$ & $\boldsymbol{Z}$ \\
\hline 2007 & 2,770 & 1,800 & 2,060 \\
2007 & 2,870 & 1,800 & 2,066 \\
2007 & 2,970 & 1,800 & 2,070 \\
2007 & 3,070 & 1,800 & 2,075 \\
2007 & 3,170 & 1,800 & 2,089 \\
2007 & 1,970 & 1,700 & 1,998 \\
2006 & 2,070 & 1,700 & 1,992 \\
2006 & 2,170 & 1,700 & 1,996 \\
2007 & 2,270 & 1,700 & 2,007 \\
2007 & 2,370 & 1,700 & 2,016 \\
2007 & 2,470 & 1,700 & 2,025 \\
2007 & 2,570 & 1,700 & 2,035 \\
2007 & 2,670 & 1,700 & 2,044 \\
2007 & 2,770 & 1,700 & 2,055 \\
2007 & 2,870 & 1,700 & 2,066 \\
2007 & 2,970 & 1,700 & 2,079 \\
2007 & 3,070 & 1,700 & 2,094 \\
2007 & 3,170 & 1,700 & 2,113 \\
2006 & 2,070 & 1,600 & 2,019 \\
2006 & 2,170 & 1,600 & 2,016 \\
2007 & 2,270 & 1,600 & 2,015 \\
2007 & 2,370 & 1,600 & 2,022 \\
2007 & 2,470 & 1,600 & 2,029 \\
2007 & 2,570 & 1,600 & 2,039 \\
2007 & 2,670 & 1,600 & 2,049 \\
2007 & 2,770 & 1,600 & 2,059 \\
2007 & 2,870 & 1,600 & 2,074 \\
2007 & 2,970 & 1,600 & 2,092 \\
2007 & 3,070 & 1,600 & 2,118 \\
2006 & 2,170 & 1,500 & 2,039 \\
2007 & 2,270 & 1,500 & 2,031 \\
2007 & 2,370 & 1,500 & 2,032 \\
2007 & 2,470 & 1,500 & 2,034 \\
2007 & 2,570 & 1,500 & 2,042 \\
2007 & 2,670 & 1,500 & 2,054 \\
2007 & 2,770 & 1,500 & 2,068 \\
2007 & 2,870 & 1,500 & 2,088 \\
2007 & 2,370 & 1,400 & 2,052 \\
2007 & 2,470 & 1,400 & 2,048 \\
2007 & 2,570 & 1,400 & 2,052 \\
2007 & 2,670 & 1,400 & 2,079 \\
& 2,770 & 1,400 & 2,103 \\
& & & \\
& & & \\
2007
\end{tabular}


Table 39. Selected characteristics of mass balance sites and mass balances at those sites on the dates of the glacier maximum winter snow balance and end of glacier balance year, South Cascade Glacier, Washington, balance years 2006 and 2007.

[Site locations are shown in figure 2. Abbreviations: $\mathrm{m}$, meter, $\mathrm{A}_{f}$, fractional attribution of grid average mass balance to indicated site during indicated balance year; $\mathrm{mWE}$, meters water equivalent; e, estimated]

\begin{tabular}{|c|c|c|c|c|c|c|c|c|c|}
\hline \multirow[b]{2}{*}{$\begin{array}{c}\text { Mass } \\
\text { balance } \\
\text { site }\end{array}$} & \multirow[b]{2}{*}{$\begin{array}{c}\text { Altitude } \\
\text { (m) }\end{array}$} & \multirow[b]{2}{*}{$A_{f}$} & \multicolumn{2}{|c|}{ Site mass balance (mWE) } & \multirow[b]{2}{*}{$\begin{array}{c}\text { Mass } \\
\text { balance } \\
\text { site }\end{array}$} & \multirow[b]{2}{*}{$\begin{array}{c}\text { Altitude } \\
\text { (m) }\end{array}$} & \multirow[b]{2}{*}{$A_{f}$} & \multicolumn{2}{|c|}{ Site mass balance (mWE) } \\
\hline & & & $\begin{array}{c}\text { Glacier } \\
\text { maximum } \\
\text { winter snow } \\
\text { balance }\end{array}$ & $\begin{array}{l}\text { End of glacier } \\
\text { balance year }\end{array}$ & & & & $\begin{array}{c}\text { Glacier } \\
\text { maximum } \\
\text { winter snow } \\
\text { balance }\end{array}$ & $\begin{array}{l}\text { End of glacier } \\
\text { balance year }\end{array}$ \\
\hline \multicolumn{5}{|c|}{ Balance year 2006} & \multicolumn{5}{|c|}{ Balance year 2007} \\
\hline S2070 & 2,066 & 0.131 & 2.66 & -1.07 & S2070 & 2,066 & 0.133 & 3.50 & 0.27 \\
\hline S2030 & 2,028 & .151 & 2.86 & -.01 & S2030 & 2,026 & .150 & 3.99 & 1.13 \\
\hline S1950 & 1,945 & .282 & 2.56 & -1.47 & S1950 & 1,945 & .286 & 3.48 & -.12 \\
\hline S1840P-1 & 1,837 & .345 & 2.68 & -1.82 & S1840P-1 & $1,836 \mathrm{e}$ & .349 & 3.30 & -.55 \\
\hline S1740 & 1,736 & .076 & 2.18 & -3.92 & $\mathrm{~S} 1740$ & 1,734 & .069 & 2.63 & -2.40 \\
\hline S1670 & 1,674 & .016 & 1.16 & -6.29 & $\mathrm{~S} 1670$ & 1,668 & .013 & 1.63 & -4.77 \\
\hline
\end{tabular}

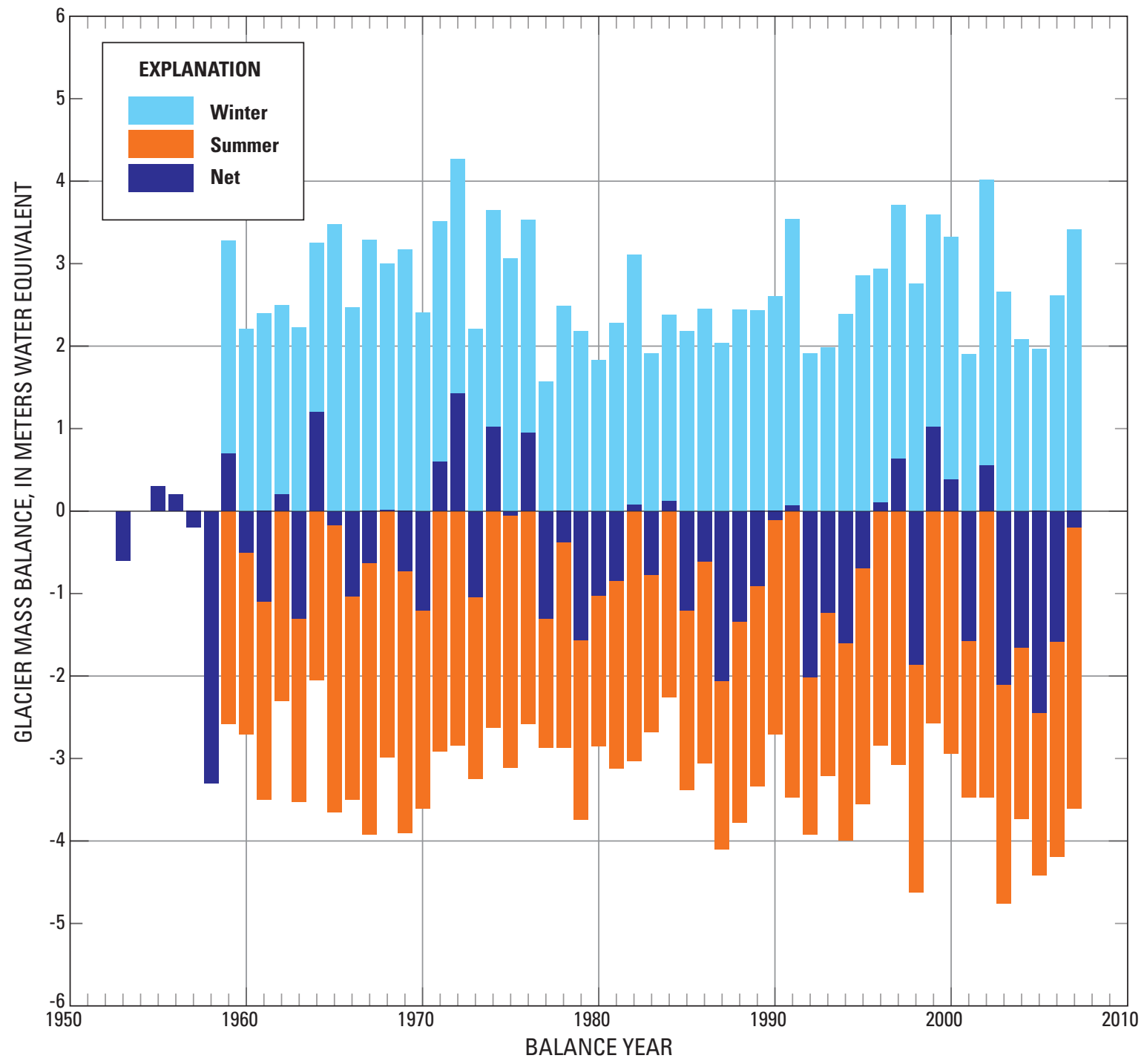

Figure 22. Winter, summer, and net balances of South Cascade Glacier, Washington, 1953 and 1955-2007. 
The 2006 summer ablated most of the previous winter's snow by late September (fig. 15). Snow from September storms intermittently covered the upper glacier and melted away. The mass balance model indicated that mass balances became negative at all six mass balance sites by late September 2006. Early October was warm enough to melt most of the new snow and the first substantial snow storm of the month did not occur until October 15. The 2006 glacier net balance was $-1.59 \mathrm{mWE}$ and the final day of balance year 2006 was October 14. Mass balances at the six mass balance sites at the end of glacier balance year 2006 are given in table 39. October 20 mass balance measurements at most of the sites confirmed that balances had become negative by that date, although new snow had subsequently covered the three uppermost sites by that date (table 29). The $2006 \bar{b}_{\text {n was }} 0.86 \mathrm{mWE}$ less negative than the 2005 $\bar{b}_{\mathrm{n}}$, but it was $1.02 \mathrm{mWE}$ more negative than the average $\bar{b}_{\text {n }}$ during 1953 to 2005 (-0.57 mWE) (table 40). The AAR was estimated to be less than 0.10 , owing to small, isolated patches of residual snow that endured the summer season. The average equilibrium-line altitude was higher than the glacier (greater than 2,125 m), because the small, isolated areas of balance-year accumulation did not represent glacier-wide conditions as did the ELA.
The glacier annual (water year) balance $\left(\bar{b}_{\mathrm{a}}\right)$ can be computed directly from a daily time series of glacier mass balance that spans the entire water year. However, the 2006 daily glacier mass balance time series computed by the mass balance model began after the start of water year 2006. The $2006 \bar{b}_{\text {a }}$ thus was computed as the sum of glacier mass balance for the period between the beginning of water year 2006 and the beginning of the modeled mass balance time series, October 20, 2006, plus the glacier mass balance for the remainder of the water year. Bidlake and others (2007) estimated the first mass balance of this sum to be $-0.11 \mathrm{mWE}$. The second mass balance of the sum was $-1.30 \mathrm{mWE}$. The $2006 \bar{b}_{\text {a }}$ was $-1.41 \mathrm{mWE}$ and the annual mass loss consisted of both firn and ice ablation.

\section{Glacier Winter, Summer, Net, and Annual Balances}

The $2007 \bar{b}_{\mathrm{m}}$ (s) of South Cascade Glacier, computed using the 36 snow mass balances presented in table 30 , was $3.23 \mathrm{mWE}$, which was $0.66 \mathrm{mWE}$ more positive (larger) than the $2006 \bar{b}_{\mathrm{m}}(\mathrm{s})$ computed for April 23-26 of the previous year.

Table 40. Winter, summer, and net balances of South Cascade Glacier, Washington, balance years 1953 and $1955-2007$.

$\left[\bar{b}_{\mathrm{m}}(\mathrm{s})\right.$, glacier measured winter snow balance; $\bar{b}_{\mathrm{W}}(\mathrm{s})$, glacier maximum winter snow balance; $\bar{b}_{\mathrm{s}}$, glacier summer balance; $\bar{b}_{\mathrm{n}}$, glacier net balance. Balances are in meters water equivalent; data for 1953 and 1955-58 are from Meier and Tangborn (1965); data for 1959-85 and 1992-2001 are from mass balance summaries and original work presented by Krimmel (1993, 1994, 1995, 1996a, 1997, 1998, 1999, 2001, and 2002); data for 1986-91 are from Krimmel (2000); and data for 2002-07 are from Bidlake and others $\left(2004,2005\right.$, and 2007) and this report. Glacier maximum winter snow balance ( $\bar{b}_{\mathrm{W}}$ (s)), if available, is given in preference to glacier measured winter snow balance $\left(\bar{b}_{\mathrm{m}}(\mathrm{s})\right)$, and in each case, the value given under the heading $\bar{b}_{\mathrm{m}}(\mathrm{s})$ or $\bar{b}_{\mathrm{W}}(\mathrm{s})$ is the best available estimate of the glacier winter balance $\left(\bar{b}_{\mathrm{w}}\right)$. Abbreviation: - , insufficient data]

\begin{tabular}{|c|c|c|c|c|c|c|c|}
\hline Balance year & $\bar{b}_{\mathrm{m}}(\mathrm{s})$ or $\bar{b}_{\mathrm{w}}(\mathrm{s})$ & $\bar{b}_{\mathrm{s}}$ & $\bar{b}_{\mathrm{n}}$ & Balance year & $\bar{b}_{\mathrm{m}}(\mathrm{s})$ or $\bar{b}_{\mathrm{W}}(\mathrm{s})$ & $\bar{b}_{\mathrm{s}}$ & $\bar{b}_{\mathrm{n}}$ \\
\hline 1953 & - & - & -0.6 & 1981 & 2.28 & -3.12 & -0.84 \\
\hline 1955 & - & - & .3 & 1982 & 3.11 & -3.03 & .08 \\
\hline 1956 & - & - & .2 & 1983 & 1.91 & -2.68 & -.77 \\
\hline 1957 & - & - & -.2 & 1984 & 2.38 & -2.26 & .12 \\
\hline 1958 & - & - & -3.3 & 1985 & 2.18 & -3.38 & -1.20 \\
\hline 1959 & 3.28 & -2.58 & .70 & 1986 & 2.45 & -3.06 & -.61 \\
\hline 1960 & 2.21 & -2.71 & -.50 & 1987 & 2.04 & -4.10 & -2.06 \\
\hline 1961 & 2.40 & -3.50 & -1.10 & 1988 & 2.44 & -3.78 & -1.34 \\
\hline 1962 & 2.50 & -2.30 & .20 & 1989 & 2.43 & -3.34 & -.91 \\
\hline 1963 & 2.23 & -3.53 & -1.30 & 1990 & 2.60 & -2.71 & -.11 \\
\hline 1964 & 3.25 & -2.05 & 1.20 & 1991 & 3.54 & -3.47 & .07 \\
\hline 1965 & 3.48 & -3.65 & -.17 & 1992 & 1.91 & -3.92 & -2.01 \\
\hline 1966 & 2.47 & -3.50 & -1.03 & 1993 & 1.98 & -3.21 & -1.23 \\
\hline 1967 & 3.29 & -3.92 & -.63 & 1994 & 2.39 & -3.99 & -1.60 \\
\hline 1968 & 3.00 & -2.99 & .01 & 1995 & 2.86 & -3.55 & -.69 \\
\hline 1969 & 3.17 & -3.90 & -.73 & 1996 & 2.94 & -2.84 & .10 \\
\hline 1970 & 2.41 & -3.61 & -1.20 & 1997 & 3.71 & -3.08 & .63 \\
\hline 1971 & 3.51 & -2.91 & .60 & 1998 & 2.76 & -4.62 & -1.86 \\
\hline 1972 & 4.27 & -2.84 & 1.43 & 1999 & 3.59 & -2.57 & 1.02 \\
\hline 1973 & 2.21 & -3.25 & -1.04 & 2000 & 3.32 & -2.94 & .38 \\
\hline 1974 & 3.65 & -2.63 & 1.02 & 2001 & 1.90 & -3.47 & -1.57 \\
\hline 1975 & 3.06 & -3.11 & -.05 & 2002 & 4.02 & -3.47 & .55 \\
\hline 1976 & 3.53 & -2.58 & .95 & 2003 & 2.66 & -4.76 & -2.10 \\
\hline 1977 & 1.57 & -2.87 & -1.30 & 2004 & 2.08 & -3.73 & -1.65 \\
\hline 1978 & 2.49 & -2.87 & -.38 & 2005 & 1.97 & -4.42 & -2.45 \\
\hline 1979 & 2.18 & -3.74 & -1.56 & 2006 & 2.61 & -4.20 & -1.59 \\
\hline 1980 & 1.83 & -2.85 & -1.02 & 2007 & 3.41 & -3.63 & -.22 \\
\hline
\end{tabular}


The 2007 glacier maximum winter snow balance $\left(\bar{b}_{\mathrm{w}}(\mathrm{s})\right)$ of $3.41 \mathrm{mWE}$ occurred May 5 , which was 6 days before the snow measurements began. Snow mass balances at the six mass balance sites at the time of the glacier maximum winter snow balance are presented in table 39. The 2007 fractional attribution of glacier mass balance to each mass balance site also is presented in table 39 . The $2007 \bar{b}_{\mathrm{w}}$ (s) was $0.80 \mathrm{mWE}$ more positive (larger) than the $2006 \bar{b}_{\mathrm{w}}(\mathrm{s})$ and it was the most positive since 2002 (fig. 22).

The 2007 glacier summer balance $\left(\bar{b}_{\mathrm{s}}\right)$ of $-3.63 \mathrm{mWE}$ was $0.57 \mathrm{mWE}$ less negative (larger) than the 2006 glacier summer balance (table 40), and the difference was partly caused by the cooler 2007 summer. Nonetheless, the $2007 \bar{b}_{\mathrm{s}}$ was $0.40 \mathrm{mWE}$ more negative (smaller) than the average $\bar{b}_{\mathrm{s}}$ during 1959 to 2006 (-3.23) (table 40).

The large 2007 winter snow accumulation and cool summer resulted in the least negative (largest) glacier net balance (-0.22 $\mathrm{mWE}$ ) since balance year 2002, which was the last year the glacier gained mass (fig. 22). Net balances at the six mass balance sites at the end of glacier balance year 2007 are given in table 39 . The $2007 \bar{b}_{\mathrm{n}}$ was $0.37 \mathrm{mWE}$ less negative than the average during 1953-2006 (-0.59 mWE). The glacier remained substantially covered by residual snow from the previous winter on September 26 (fig. 17), the penultimate day of balance year 2007, and the estimated AAR and ELA were 0.60 and $1,880 \mathrm{~m}$, respectively. The $2007 \bar{b}_{\mathrm{a}}$ was $-0.45 \mathrm{mWE}$ and the annual mass loss consisted almost exclusively of ice ablation.

\section{Glacier Mass Balance Uncertainties}

Glacier mass balances computed for this report were subject to errors stemming from the previously discussed errors in measured mass balances at selected sites and to sampling errors caused by spatial variability of mass balance quantities.

Some information about mass balance errors from spatial variability of South Cascade Glacier can be inferred from the work of Fountain and Vecchia (1999), who developed net balance-versus-altitude regression models primarily to assess the effect of spatial measurement density on computed glacier net balance. They repeatedly sub-sampled net balance data from relatively dense ablation stake networks the USGS used at South Cascade Glacier in 1965, 1966, and 1968. Glacier net balance computed from selected sets of five altitudinally distributed stakes differed by as much as about $0.9 \mathrm{mWE}$ for 1965 , by as much as $0.5 \mathrm{mWE}$ for 1966 , and by as much as $0.4 \mathrm{mWE}$ for 1968 , depending on which particular stakes were selected to populate the sets. The total number of stakes that Fountain and Vecchia (1999) were able to select from was small from a statistical standpoint, as the authors acknowledged, and drawing statistical inferences from their experiments about uncertainties in the glacier mass balances presented in this report might not be warranted. For purposes of this report, the experimental ranges of net balance computed using small numbers a measurement sites, described previously, support heuristic arguments that uncertainties in the glacier mass balances presented in this report are on the order of a few to several tenths of a meter.

\section{Glacier Effects on Summer Runoff}

Differing and time-varying sources of runoff water were responsible for the differences in summer runoff from Middle Tarn and Salix Creek basins. Summer runoff from nonglacierized Salix Creek basin was fed primarily by melt of the annual snow pack and precipitation. Because snow was almost all gone from Salix Creek basin by late July of both 2006 and 2007 and little precipitation fell during August through September of both years, runoff decreased to generally less than $2 \mathrm{~mm} / \mathrm{d}$ during both water years (tables 20 and $\underline{23}$ ) and the ratio of runoff to precipitation approached 1:1 (fig. 10).

Summer runoff from Middle Tarn basin also was fed by melt of the annual snow pack. By August and September of 2006 and 2007; however, runoff still was several times greater than precipitation, whether or not a substantial amount of the annual snow pack remained or not. In 2006, most of the annual snowpack in Middle Tarn basin melted by August and runoff during that month and September were substantially augmented by melting of firn and ice. Water-year ablation of firn and ice, computed from the 2006 glacier annual balance (-1.41 mWE), was equivalent to $550 \mathrm{~mm}$ of runoff from Middle Tarn basin. Most of the annual firn and ice melt occurs during August and September and the $2006 \bar{b}_{\mathrm{a}}$ was equivalent to about 60 percent of the gaged basin runoff during those months (922 mm).

The relatively large winter 2007 winter snow pack played a much more dominate role in maintaining late-summer runoff from Middle Tarn basin than it did during summer 2006. The annual snow pack shielded the firn and ice from the elements to a greater extent and later into the season than it did during 2006. Thus, the release of water from melt of glacier ice and firn, which was computed from the $2007 \bar{b}_{\mathrm{a}}(-0.45 \mathrm{mWE})$, was equivalent to only about 17 percent of the gaged basin runoff during August and September (1,036 mm).

From the standpoint of streamflows, South Cascade Glacier performs similarly to a reservoir in that water stored and released by the glacier dampens streamflow responses to precipitation variability. The ecological importance of glaciers for stabilizing river flows in downstream habitats is a research area that could help in understanding more completely some of the effects of climate change.

\section{Terminus Retreat and Glacier Area}

The glacier terminus retreated during 2006 and 2007, as it has during every year of measurement except 1972 (Krimmel, 2002). Terminus retreat rate during September 21, 2005, to September 28, 2006, averaged 
approximately $13 \mathrm{~m} / \mathrm{yr}$ (fig. 14). Retreat rate during September 28, 2006, to September 26, 2007, averaged approximately $8 \mathrm{~m} / \mathrm{yr}$ (fig. 16). Some of the terminus margin was in shadow at the times the vertical aerial photographs were acquired in 2006 and 2007 (figs. 15 and 17). The shadows obscured the ice margin, and the outline of the glacier mapped near the terminus was that of the visible ice, which could have differed from the actual ice margin by as much as several meters. Estimated uncertainty of the retreat rates was about $5 \mathrm{~m} / \mathrm{yr}$.

The retreating terminus caused glacier area to decrease in 2006 and 2007. Glacier area on September 21, 2005, was $1.75 \mathrm{~km}^{2}$ (Bidlake and others, 2007). The 2006 and 2007 retreats each decreased glacier area north of local $\mathrm{Y}=2,900 \mathrm{~m}$ by $0.01 \mathrm{~km}^{2}$. Area of the upper glacier (south of local $\mathrm{Y}=2,900 \mathrm{~m}$ ) was assumed to have remained stable since the end of balance year 2005. Thus, glacier area in late-September 2006 and 2007 was $1.74 \mathrm{~km}^{2}$ and $1.73 \mathrm{~km}^{2}$, respectively. Glacier area decreases during 2006 and 2007 were substantially smaller than the $0.07-\mathrm{km}^{2}$ decreases during both 2004 and 2005. The smaller 2006 and 2007 area decreases were due in part to the larger winter snow packs of those years that persisted and shielded the underlying glacier firn and ice later into the respective summer seasons than during the previous 2 years.

The continued retreat and loss of mass by South Cascade Glacier during 2006 and 2007 was consistent with overall trends since 1953. These overall trends of decreasing glacier extent and mass indicate that South Cascade Glacier continues to respond to climate conditions that will not support the glacier in its recent size and position on the landscape (Rasmussen and Conway, 2001).

\section{Summary and Conclusions}

The long-term U.S. Geological Survey monitoring of South Cascade Glacier, Washington, a benchmark glacier for the extensively glacierized North Cascade Mountains, is part of U.S. Geological Survey glacier research. Meteorological, hydrological, and glaciological research and monitoring of South Cascade Glacier has been carried out for more than 5 decades, and this report presents the most significant work and research findings for balance years 2006 and 2007.

The mass of a glacier, the combined masses of its snow and ice, is constantly changing through the operation of opposing processes of accumulation and ablation. Mass balance, the difference between accumulated and ablated glacier mass over time, is an important measure of glacier change. Glaciological measurement and modeling were used for this report to describe mass balance at selected sites on and for the whole of South Cascade Glacier during balance years 2006 and 2007.

Hydrological and meteorological data related to glacier change and status were measured on and near the glacier.
Surface-water runoff from the basin containing South Cascade Glacier and from a nearby unglacierized basin were gaged. Air temperature was measured at several sites on the glacier and at nearby sites. Wind speed, incoming solar radiation, and precipitation (gage catch) were measured near the glacier. The resulting hydrological and meteorological data are presented in this report.

Analysis of air temperature measured at a height of 2 meters at selected sites of varying altitude on the glacier indicated the ice and snow mass strongly affected the microclimate. Temperature lapse rates typical of the lower atmosphere adequately described air-temperature variations among the sites only when air temperature approached that of the glacier surface. The glacier cooled the air near its surface and the amount by which the air was cooled increased as temperature of ambient air over South Cascade Lake basin increased. This report describes development and application of an empirically based technique for predicting air temperature at selected sites over the glacier on the basis of temperature at an off-glacier reference site.

A simple model using selected meteorological data was developed to model mass balance on a daily time step at selected glacier sites. Modeled snow accumulation was daily precipitation that occurred when air temperature was equal to or less than a critical threshold temperature. Modeled daily ablation was directly proportional to daily positive degree days, which was the sum of daily average air temperatures that were greater than $0^{\circ} \mathrm{C}$. The model tracked snow, firn, and ice mass balances and had three adjustable factors that were varied within constraining limits to match modeled mass balances to the respective measured mass balances.

Mass balances at selected sites were averaged over the area of the glacier using an interpolation scheme in which balances were assumed to vary linearly with altitude between sites. The integration scheme, which resulted from modification of a previously published scheme, was applied using the glacier area distribution with altitude and modeled daily mass balances at selected sites to yield a daily time series of glacier mass balance. The daily glacier time series of glacier mass balance were then queried to obtain the 2006 and 2007 glacier winter, summer, net, and annual mass balances.

The North Cascade Range in the vicinity of South Cascade Glacier accumulated about normal to above normal winter snow packs during water years 2006 and 2007. As a result, the 2006 and 2007 maximum winter snow balances of South Cascade Glacier were roughly equal to or greater than the long-term average.

The glacier lost mass during balance years 2006 and 2007. The 2006 glacier net balance, $-1.59 \mathrm{mWE}$, was $1.02 \mathrm{mWE}$ more negative (smaller) than the 1953-2005 average. The 2007 glacier net balance, $-0.22 \mathrm{mWE}$, was $0.37 \mathrm{mWE}$ less negative (larger) than the average during 1953-2006. The net balance is the sum of the winter and summer balances, and the larger winter snow accumulation and cooler summer of 2007 were primarily responsible for the difference between the 2006 and 2007 net balances. The 2006 
and 2007 glacier maximum winter snow balances were 2.61 and $3.41 \mathrm{mWE}$, respectively. June-September 2007 was $2.0^{\circ} \mathrm{C}$ cooler at the Hut than in 2006, and the 2007 glacier summer balance (-3.63 $\mathrm{mWE}$ ) was $0.57 \mathrm{mWE}$ less negative than the 2006 glacier summer balance $(-4.20 \mathrm{mWE})$.

The terminus of South Cascade glacier retreated during 2006 and 2007, as it has during every year of measurement since 1972. The average retreat rate during balance year 2006 was about $13 \mathrm{~m} / \mathrm{yr}$ and the average retreat rate during balance year 2007 was about $8 \mathrm{~m} / \mathrm{yr}$. Total glacier area decreased by $0.01 \mathrm{~km}^{2}$ each year. Selected glaciological quantities and dates for balance years 2006 and 2007 presented previously in this report are also summarized in table 41.

The continued retreat and loss of mass by South Cascade Glacier during 2006 and 2007 was consistent with overall trends since 1953. These overall trends of decreasing glacier extent and mass indicate that South Cascade Glacier has been responding to climate conditions that will not support the glacier in its recent size and position on the landscape.

\section{Acknowledgments}

The authors acknowledge the substantial field-work assistance of Volunteers for Science, Faron Anslow and George Spooner, and of five Climbing Rangers with the United States Department of Agriculture, Forest Service: Soren Cunningham, Kevin Hammonds, Kurt Parker, Brandon Helmstetter, and Nick Hall.

\section{References Cited}

Anonymous, 1969, Mass-balance terms: Journal of Glaciology, v. 8, no. 52, p. 3-7.

Anslow, S.F., Hostetler, Steven, Bidlake, W.R., and Clark, P.U., 2008, Distributed energy balance modeling of South Cascade Glacier, Washington and assessment of model uncertainty: Journal of Geophysical Research, v. 113, F02019, doi:10.1029/2007JF000850.

Bidlake, W.R., Josberger, E.G., and Savoca, M.E., 2004, Water, ice, and meteorological measurements at South Cascade Glacier, Washington, balance year 2002: U.S. Geological Survey Scientific Investigations Report 2004-5089, 38 p.

Bidlake, W.R., Josberger, E.G., and Savoca, M.E., 2005, Water, ice, and meteorological measurements at South Cascade Glacier, Washington, balance year 2003: U.S. Geological Survey Scientific Investigations Report 2005-5210, 48 p.
Table 41. Selected glaciological quantities and dates for South Cascade Glacier, balance years 2006 and 2007.

[Abbreviations: $\mathrm{mWE}$, meters water equivalent; $\mathrm{m}$, meter; $\mathrm{m} / \mathrm{yr}$, meter per year; $\mathrm{km}^{2}$, square kilometer; >, greater than; <, less than]

\begin{tabular}{|c|c|c|}
\hline \multirow{2}{*}{$\begin{array}{l}\text { Glaciological } \\
\text { quantity or date }\end{array}$} & \multicolumn{2}{|c|}{ Balance year } \\
\hline & 2006 & 2007 \\
\hline $\begin{array}{l}\text { Glacier maximum winter } \\
\text { snow balance }\left(\bar{b}_{\mathrm{w}}(\mathrm{s})\right)\end{array}$ & $2.61 \mathrm{mWE}$ & $3.41 \mathrm{mWE}$ \\
\hline $\begin{array}{l}\text { Ending date of winter } \\
\text { season }\end{array}$ & April 18, 2006 & May 5, 2007 \\
\hline $\begin{array}{l}\text { Glacier summer balance } \\
\qquad\left(\bar{b}_{\mathrm{s}}\right)\end{array}$ & $-4.20 \mathrm{mWE}$ & $-3.63 \mathrm{mWE}$ \\
\hline $\begin{array}{l}\text { Ending date of summer } \\
\text { season }\end{array}$ & October 14, 2006 & September 27, 2007 \\
\hline Glacier net balance $\left(\bar{b}_{\mathrm{n}}\right)$ & $-1.59 \mathrm{mWE}$ & $-0.22 \mathrm{mWE}$ \\
\hline $\begin{array}{c}\text { Glacier annual (water } \\
\text { year) balance }\left(\bar{b}_{\mathrm{a}}\right)\end{array}$ & $-1.41 \mathrm{mWE}$ & $-0.45 \mathrm{mWE}$ \\
\hline Terminus retreat rate & $13 \mathrm{~m} / \mathrm{yr}$ & $8 \mathrm{~m} / \mathrm{yr}$ \\
\hline $\begin{array}{l}\text { Glacier area on } \\
\text { September 28, } 2006\end{array}$ & $1.74 \mathrm{~km}^{2}$ & \\
\hline $\begin{array}{l}\text { Glacier area on } \\
\text { September 26, } 2007\end{array}$ & & $1.73 \mathrm{~km}^{2}$ \\
\hline $\begin{array}{l}\text { Accumulation area ratio } \\
\text { (AAR) }\end{array}$ & $<0.10$ & 0.60 \\
\hline $\begin{array}{l}\text { Average equilibrium line } \\
\text { altitude (ELA) }\end{array}$ & $>2,125 \mathrm{~m}$ & $1,880 \mathrm{~m}$ \\
\hline
\end{tabular}

Bidlake, W.R., Josberger, E.G., and Savoca, M.E., 2007, Water, ice, and meteorological measurements at South Cascade Glacier, Washington, balance years 2004 and 2005: U.S. Geological Survey Scientific Investigations Report 2007-5055, 70 p.

Bitz, C.M., and Battisti, D.S., 1999, Interannual to decadal variability in climate and glacier mass balance in Washington, Western Canada, and Alaska: Journal of Climate, v. 12, p. 3181-3196.

Braithwaite, R.J., 2008, Temperature and precipitation climate at the equilibrium-line altitude of glaciers expressed by the degree-day factor for snow: Journal of Glaciology, v. 54, no. 186, p. 437-444.

Brutsaert, Wilfried, 1982, Evaporation into the atmosphere: Boston, Mass., D. Reidel, 299 p. (Reprinted with corrections 1984; reprinted 1988).

Conway, Howard, Rasmussen, L.A., and Marshall, H.P., 1999, Annual mass balance of Blue Glacier, USA - 1957-97: Geografiska Annaler, v. 81A, no. 4, p. 509-520. 
Dyurgerov, M.B., and Meier, M.F., 1997, Year-to-year fluctuations of global mass balance of small glaciers and their contribution to sea-level changes: Arctic and Alpine Research, v. 29, no. 4, p. 392-402.

Fountain, A.G., Krimmel, R.M., and Trabant, D.C., 1997, A strategy for monitoring glaciers: U.S. Geological Survey Circular 1132, $19 \mathrm{p}$.

Fountain, A.G., and Tangborn, W.V., 1985, The effect of glaciers on streamflow variations: Water Resources Research, v. 21, no. 4, p. 579-586.

Fountain, A.G., and Vecchia, Aldo, 1999, How many stakes are required to measure the mass balance of a glacier?: Geografiska Annaler, Volume 81 A, no. 4, p. 563-573.

Greuell, Wouter, and Böhm, Reinhold, 1998, 2 m temperatures along melting mid-latitude glaciers, and implications for the sensitivity of the mass balance to variations in temperature: Journal of Glaciology, v. 44, no. 146, p. 9-20.

Haeberli, Wilfried, Hoelzle, Martin, and Zemp, Michael, eds., 2007, Glacier mass balance bulletin no. 9 (2004-05): Zurich, Switzerland, World Glacier Monitoring Service, Department of Geography, University of Zurich, 100 p.

Hock, Regine, 2003, Temperature index melt modeling in mountain areas: Journal of Hydrology, v. 282, p. 104-115.

Hodge, S.M., Trabant, D.C., Krimmel, R.M., Heinrichs, T.A., March, R.S., and Josberger, E.G., 1998, Climate variations and changes in mass of three glaciers in western North America: Journal of Climate, v. 11, no. 9, p. 2161-2179.

Josberger, E.G., Bidlake, W.R., March, R.S., and Kennedy, B.W., 2007, Glacier mass-balance fluctuations in the Pacific Northwest and Alaska, USA: Annals of Glaciology, v. 46, p. 291-296.

Krimmel, R.M., 1989, Mass balance and volume of South Cascade Glacier, Washington, 1958-1985, in Oerlemans, Johannes, ed., Glacier fluctuations and climatic change: Dordrecht, The Netherlands, Kluwer Academic Publishers, p. 193-206.

Krimmel, R.M.,1993, Mass balance, meteorological, and runoff measurements at South Cascade Glacier, Washington, 1992 balance year: U.S. Geological Survey Open-File Report 93-640, 38 p.

Krimmel, R.M., 1994, Runoff, precipitation, mass balance, and ice velocity measurements at South Cascade Glacier, Washington, 1993 balance year: U.S. Geological Survey Water-Resources Investigations Report 94-4139, 35 p.

Krimmel, R.M., 1995, Water, ice, and meteorological measurements at South Cascade Glacier, Washington, 1994 balance year: U.S. Geological Survey Water-Resources Investigations Report 95-4162, 41 p.
Krimmel, R.M., 1996a, Water, ice, and meteorological measurements at South Cascade Glacier, Washington, 1995 balance year: U.S. Geological Survey Water-Resources Investigations Report 96-4174, 37 p.

Krimmel, R.M., 1996b, Glacier mass balance using the grid-index method, in Colbeck, S.C., ed., Glaciers, ice sheets and volcanoes - A tribute to Mark F. Meier: U.S. Army Corps of Engineers Cold Regions Research and Engineering Laboratory Special Report 96-27, p. 62-68.

Krimmel, R.M., 1997, Water, ice, and meteorological measurements at South Cascade Glacier, Washington, 1996 balance year: U.S. Geological Survey Water-Resources Investigations Report 97-4143, $34 \mathrm{p}$.

Krimmel, R.M., 1998, Water, ice, and meteorological measurements at South Cascade Glacier, Washington, 1997 balance year: U.S. Geological Survey Water-Resources Investigations Report 98-4090, $30 \mathrm{p}$.

Krimmel, R.M., 1999, Water, ice, meteorological and speed measurements at South Cascade Glacier, Washington, 1998 balance year: U.S. Geological Survey Water-Resources Investigations Report 99-4049, $36 \mathrm{p}$.

Krimmel, R.M., 2000, Water, ice, and meteorological measurements at South Cascade Glacier,Washington, 1986-91 balance years: U.S. Geological Survey Water-Resources Investigations Report 00-4006, 77 p.

Krimmel, R.M., 2001, Water, ice, meteorological, and speed measurements at South Cascade Glacier, Washington, 1999 balance year: U.S. Geological Survey Water-Resources Investigations Report 00-4265, $36 \mathrm{p}$.

Krimmel, R.M., 2002, Water, ice, and meteorological measurements at South Cascade Glacier, Washington, 2000-01 balance years: U.S. Geological Survey Water-Resources Investigations Report 02-4165, 63 p.

Krimmel, R.M., and Tangborn, W.V., 1974, South Cascade Glacier-The moderating effect of glaciers on runoff: Western Snow Conference, 42d Annual Meeting, Anchorage, Alaska, 1974, Proceedings, p. 9-13.

Mantua, N.J., Hare, S.R., Zhang, Yaun, Wallace, J.M., and Francis, R.C., 1997, A Pacific interdecadal climate oscillation with impacts on salmon production: Bulletin of the American Meteorological Society., v. 78, no. 6, p. 1069-1079.

March, R.S., 1998, Mass balance, meteorological, ice motion, surface altitude, and runoff data at Gulkana Glacier, Alaska, 1994 balance year: U.S. Geological Survey Water-Resources Investigations Report 97-4251, 31 p. 
March, R.S., 2003, Mass balance, meteorology, area altitude distribution, glacier-surface altitude, ice motion, terminus position, and runoff at Gulkana Glacier, Alaska, 1996 balance year: U.S. Geological Survey Water-Resources Investigations Report 03-4095, 33 p.

Mayo, L.R., Meier, M.F., and Tangborn, W.V., 1972, A system to combine stratigraphic and annual mass-balance systems-A contribution to the International Hydrological Decade: Journal of Glaciology, v. 11, no. 61, p. 3-14.

Mayo, L.R., Trabant, D.C., and March, R.S., 2004, A 30-year record of surface mass balance (1966-95), and motion and surface altitude (1975-95) at Wolverine Glacier, Alaska: U.S. Geological Survey Open-File Report 2004-1069, $105 \mathrm{p}$.

Meier, M.F., 1958, Research on South Cascade Glacier: The Mountaineer, v. 51, no. 4, p. 40-47.

Meier, M.F., and Tangborn, W.V., 1965, Net budget and flow of South Cascade Glacier, Washington: Journal of Glaciology, v. 5, no. 41, p. 547-566.

Meier, M.F., Tangborn, W.V., Mayo, L.R., and Post, Austin, 1971, Combined ice and water balances of Gulkana and Wolverine Glaciers, Alaska, and South Cascade Glacier, Washington, 1965 and 1966 hydrologic years: U.S. Geological Survey Professional Paper 715-A, 23 p.

National Climatic Data Center, 2009, Surface data, daily US: U.S. Department of Commerce, data were accessed February 2-3, 2009, at http://www.ncdc.noaa.gov/oa/ncdc. html.

National Water and Climate Center, 2009, Washington SNOTEL sites: U.S. Department of Agriculture, Natural Resources Conservation Service, data were accessed February 24, 2009, at http://www.wcc.nrcs.usda.gov/snotel/ Washington/washington.html.

Ohmura, Atsumu, 2001, Physical basis for the temperature-based melt-index method: Journal of Applied Meteorology, v. 40, no. 4, p. 753-761.

Paterson, W.S.B., 1994, The physics of glaciers (3d ed.): Tarrytown, New York, Elsevier Science, Inc., 480 p.

Post, Austin, Richardson, Don, Tangborn, W.V., and Rosselot, F.L., 1971, Inventory of glaciers in the North Cascades, Washington: U.S. Geological Survey Professional Paper 705-A, $26 \mathrm{p}$.

PRISM Climate Group, 2006, Average annual precipitation, 1971-2000, Washington: Oregon State University, http:// www.prismclimate.org, one-page map accessed October 22, 2009.

Radić, Valentina, Hock, Regine, and Oerlemans, Johannes, 2008, Analysis of scaling methods in deriving future volume evolutions of valley glaciers: Journal of Glaciology, v. 54 , no. 87 , p. $601-612$.
Rantz, S.E., and others, 1982, Measurement and computation of streamflow-Volume 2. Computation of discharge: U.S. Geological Survey Water-Supply Paper 2175, 347 p.

Rasmussen, L.A., and Conway, Howard, 2001, Estimating South Cascade Glacier (Washington, U.S.A.) mass balance from a distant radiosonde and comparison with Blue Glacier: Journal of Glaciology, v. 47, no. 159, p. 579-588.

Rasmussen, L.A., and Conway, Howard, 2004, Climate and glacier variability in western North America: Journal of Climate, v. 17, no. 9, p. 1804-1815.

Rasmussen, L.A., and Conway, H.B., 2003, Using upper-air conditions to estimate South Cascade Glacier (Washington, U.S.A.) summer balance: Journal of Glaciology, v. 49, no. 166 , p. $456-462$.

Sullivan, M.E., 1994, South Cascade Glacier, WashingtonHydrologic and meteorological data, 1957-67: U.S. Geological Survey Open-File Report 94-77, 105 p.

Tangborn, W.V., 1980, Two models for estimating climateglacier relationships in the North Cascades, Washington, U.S.A.: Journal of Glaciology, v. 25, no. 91, p. 3-21.

Tangborn, W.V.. 1999, A mass-balance model that uses lowaltitude meteorological observations and the area-altitude distribution of a glacier: Geografiska Annaler, v. 81 A, no. 4, p. 753-765.

Tangborn, W.V., Mayo, L.R., Scully, D.R., and Krimmel, R.M., 1977, Combined ice and water balances of Maclure Glacier, California, South Cascade Glacier, Washington, and Wolverine and Gulkana Glaciers, Alaska, 1967 hydrologic year: U.S. Geological Survey Professional Paper 715-B, $20 \mathrm{p}$.

U.S. Geological Survey, 2009, Benchmark glaciers: U.S. Geological Survey website, accessed September 29, 2009, at http://ak.water.usgs.gov/glaciology/index.html.

U.S. Naval Observatory, 2007, Duration of daylight/darkness table for one year: Washington, D.C., U.S. Navy, U.S. Naval Observatory, Astronomical Applications Department database, accessed December 20, 2007, at http://www.usno. navy.mil/USNO/astronomical-applications/data-services/ rs-one-year-us.

Wallace, J.M., and Hobbs, P.V., 1977. Atmospheric scienceAn introductory survey: Orlando, Fla., Academic Press, $467 \mathrm{p}$.

Walters, R.W., and Meier, M.F., 1989, Variability of glacier mass balances in western North America, 1 in Peterson, D. H., ed., Aspects of climate variability in the Pacific and the western Americas: Washington D.C., American Geophysical Union, Geophysical Monograph 55, p. 365-374. 


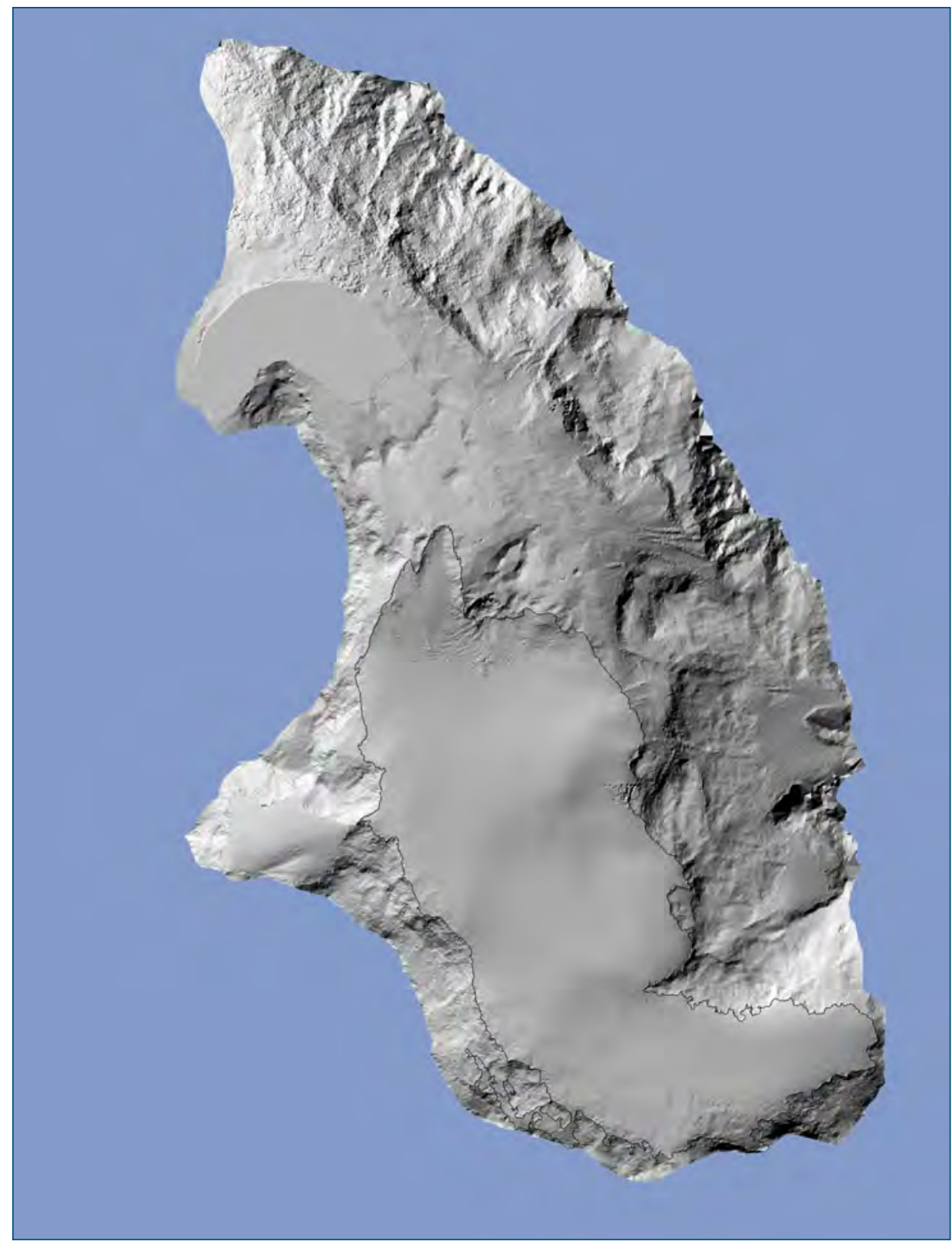

Shaded-relief image of South Cascade Lake basin, Washington, created from vertical aerial photographs taken September 28, 2006. South Cascade Glacier and its adjoining snow field are outlined in black.

\section{Data CD}

The data CD can be accessed and downloaded at URL http://pubs.usgs.gov/sir/2010/5143.

\section{Data CD}

Surface-altitude grid data for South Cascade Glacier, Washington, 2006 and 2007.

(Published on CD - In pocket at back or printed repot)

ABOUT THIS CD.rtf

SCG $062 \mathrm{~m}$ localyx.dat

SCG $072 \mathrm{~m}$ localxy.dat 
Publishing support provided by the U.S. Geological Survey Publishing Network, Tacoma Publishing Service Center

Director, Washington Water Science Center U.S. Geological Survey

934 Broadway - Suite 300

Tacoma, Washington 98402

http://wa.water.usgs.gov/ 
